\title{
‡USGS
}

science for a changing world

National Water-Quality Assessment Program

\section{Ground-Water Quality in the Central High Plains Aquifer, Colorado, Kansas, New Mexico, Oklahoma, and Texas, 1999}

Water-Resources Investigations Report 02-4112
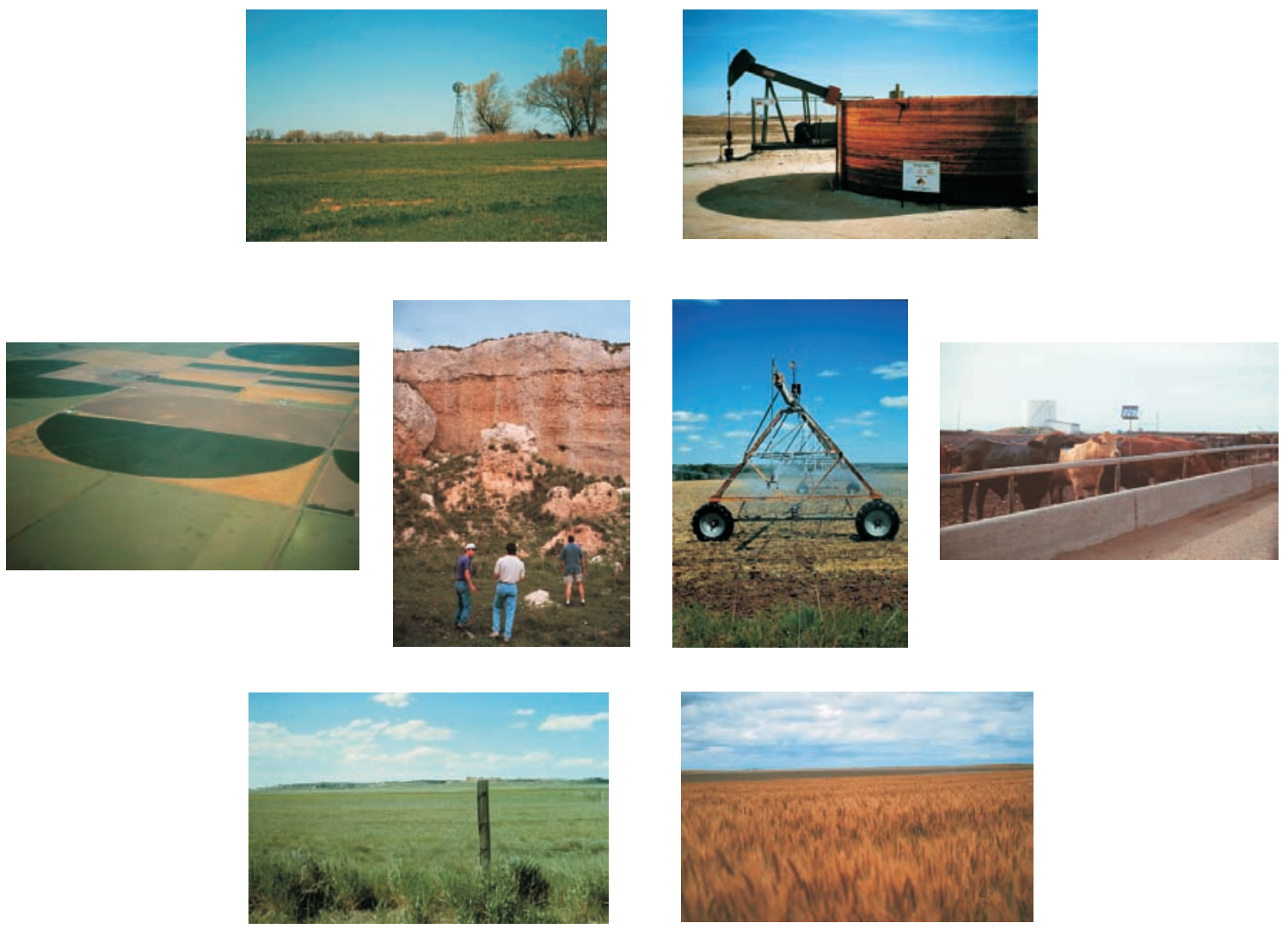
U.S. Department of the Interior

U.S. Geological Survey

\section{Ground-Water Quality in the Central High Plains Aquifer, Colorado, Kansas, New Mexico, Oklahoma, and Texas, 1999}

By Mark F. Becker, Breton W. Bruce, Larry M. Pope, and William J. Andrews

Water-Resources Investigations Report 02-4112 


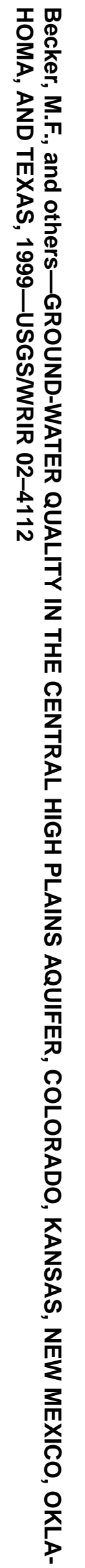




\section{U.S. Department of the Interior \\ GALE A. NORTON, Secretary}

\section{U.S. Geological Survey}

CHARLES G. GROAT, Director

The use of firm, trade, and brand names in this report is for identification purposes only and does not constitute endorsement by the U.S. Geological Survey.

UNITED STATES GOVERNMENT PRINTING OFFICE: OKLAHOMA CITY 2002

For additional information write to:

District Chief

U.S. Geological Survey

Water-Resources Division

202 NW 66 St., Bldg. 7

Oklahoma City, OK 73116
Copies of this report can be purchased from:

U.S. Geological Survey

Information Services

Box 25286

Federal Center

Denver, CO 80225

Additional information about water resources in Oklahoma is available on the World Wide Web at http://ok.water.usgs.gov 


\section{FOREWORD}

The U.S. Geological Survey (USGS) is committed to serve the Nation with accurate and timely scientific information that helps enhance and protect the overall quality of life, and facilitates effective management of water, biological, energy, and mineral resources. Information on the quality of the Nation's water resources is of critical interest to the USGS because it is so integrally linked to the longterm availability of water that is clean and safe for drinking and recreation and that is suitable for industry, irrigation, and habitat for fish and wildlife. Escalating population growth and increasing demands for the multiple water uses make water availability, now measured in terms of quantity and quality, even more critical to the long-term sustainability of our communities and ecosystems.

The USGS implemented the National WaterQuality Assessment (NAWQA) Program to support national, regional, and local information needs and decisions related to water-quality management and policy. Shaped by and coordinated with ongoing efforts of other Federal, State, and local agencies, the NAWQA Program is designed to answer: What is the condition of our Nation's streams and ground water? How are the conditions changing over time? How do natural features and human activities affect the quality of streams and ground water, and where are those effects most pronounced? By combining information on water chemistry, physical characteristics, stream habitat, and aquatic life, the NAWQA Program aims to provide science-based insights for current and emerging water issues. NAWQA results can contribute to informed decisions that result in practical and effective water-resource management and strategies that protect and restore water quality.

Since 1991, the NAWQA Program has implemented interdisciplinary assessments in more than 50 of the Nation's most important river basins and aquifers, referred to as Study Units. Collectively, these Study Units account for more than 60 percent of the overall water use and population served by public water supply, and are representative of the Nation's major hydrologic landscapes, priority ecological resources, and agricultural, urban, and natural sources of contamination.

Each assessment is guided by a nationally consistent study design and methods of sampling and analysis. The assessments thereby build local knowl- edge about water-quality issues and trends in a particular stream or aquifer while providing an understanding of how and why water quality varies regionally and nationally. The consistent, multi-scale approach helps to determine if certain types of waterquality issues are isolated or pervasive, and allows direct comparisons of how human activities and natural processes affect water quality and ecological health in the Nation's diverse geographic and environmental settings. Comprehensive assessments on pesticides, nutrients, volatile organic compounds, trace metals, and aquatic ecology are developed at the national scale through comparative analysis of the Study-Unit findings.

The USGS places high value on the communication and dissemination of credible, timely, and relevant science so that the most recent and available knowledge about water resources can be applied in management and policy decisions. We hope this NAWQA publication will provide you the needed insights and information to meet your needs, and thereby foster increased awareness and involvement in the protection and restoration of our Nation's waters.

The NAWQA Program recognizes that a national assessment by a single program cannot address all water-resource issues of interest. External coordination at all levels is critical for a fully integrated understanding of watersheds and for cost-effective management, regulation, and conservation of our Nation's water resources. The Program, therefore, depends extensively on the advice, cooperation, and information from other Federal, State, interstate, Tribal, and local agencies, non-government organizations, industry, academia, and other stakeholder groups. The assistance and suggestions of all are greatly appreciated.

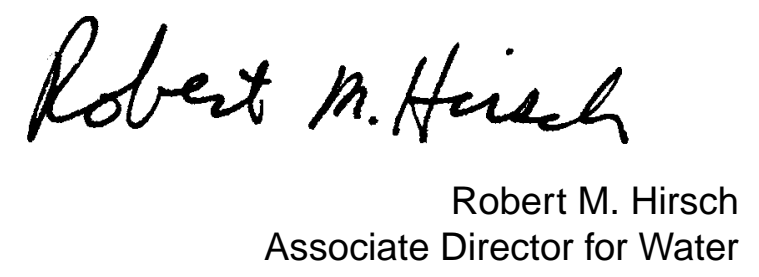




\section{CONTENTS}

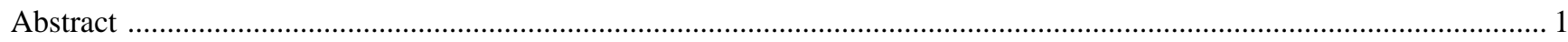

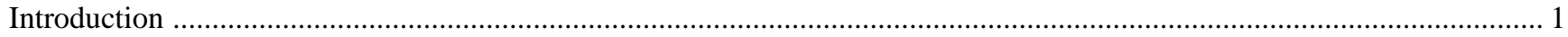

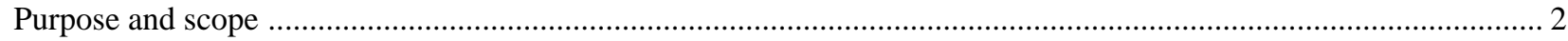

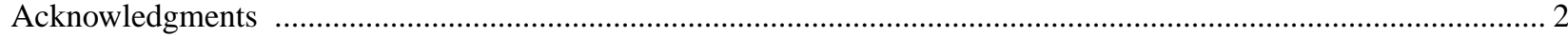

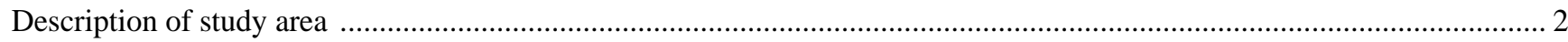

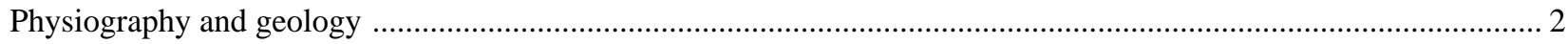

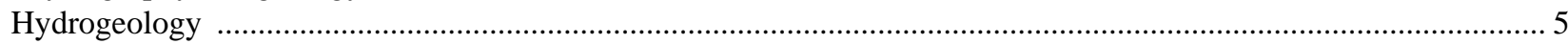

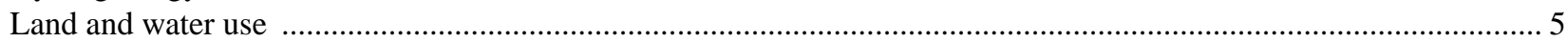

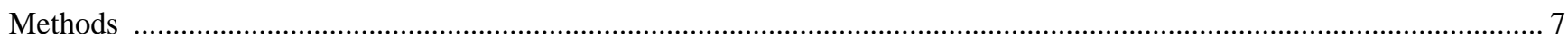

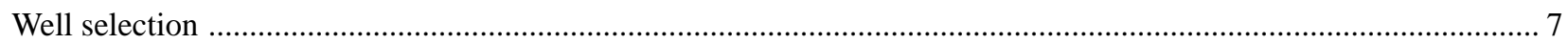

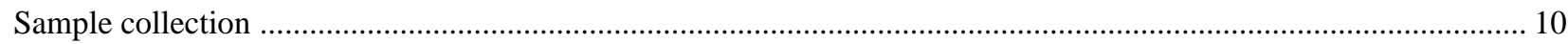

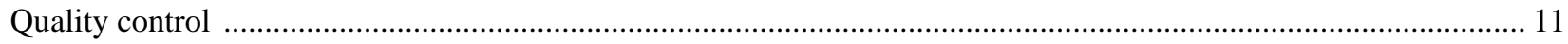

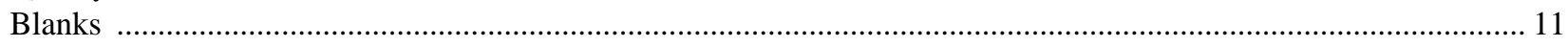

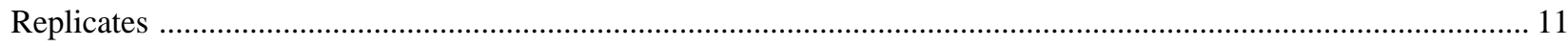

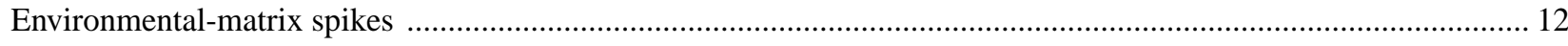

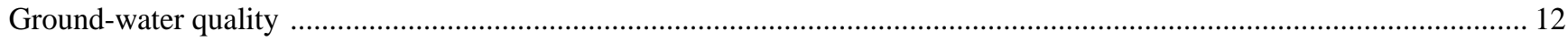

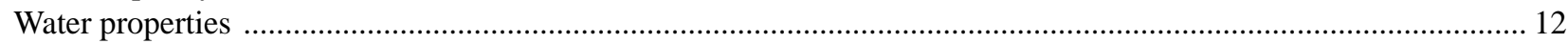

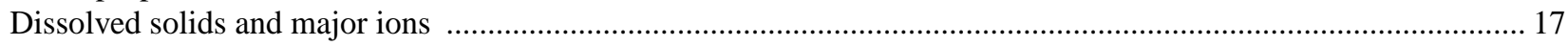

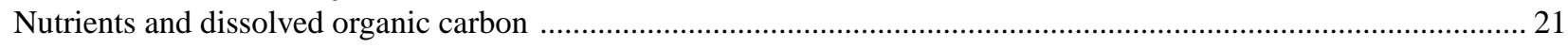

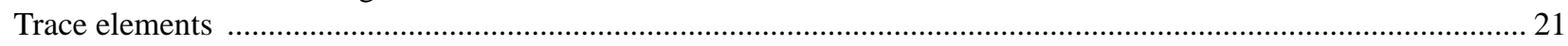

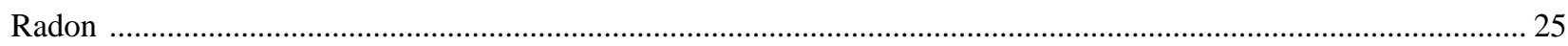

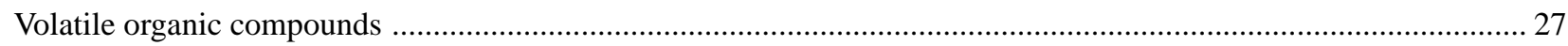

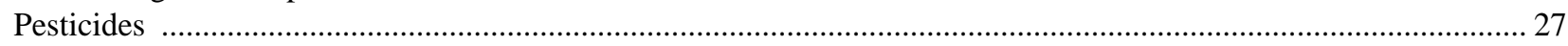

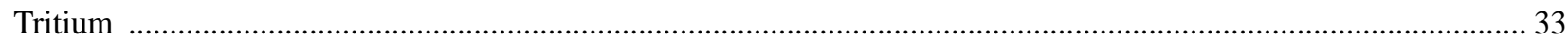

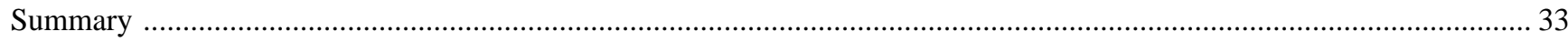

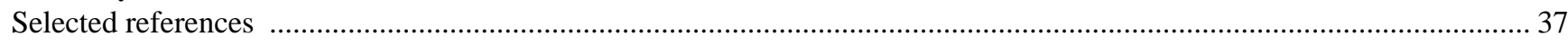

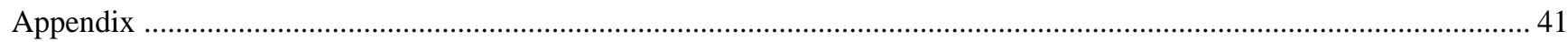

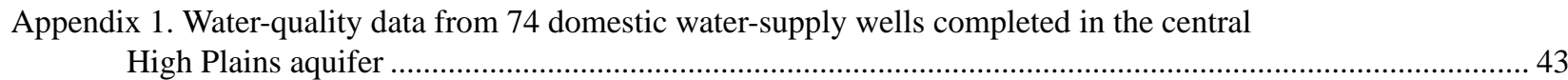

\section{ILLUSTRATIONS}

Figures 1-3. Maps showing:

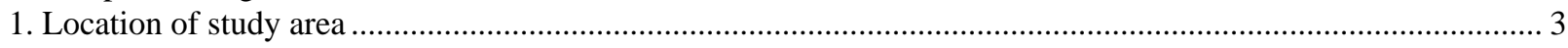

2. Locations of 74 domestic water-supply wells sampled for assessment of ground-water quality in the central High Plains aquifer, 1999 .................................................................................................... 4

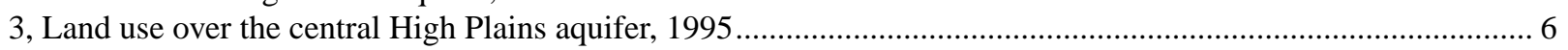

4. Piper diagram showing major ion concentrations in samples collected in 1999 from 74 domestic water-supply wells completed in the central High Plains aquifer

5. Graph showing distribution of concentrations of major ions in samples collected in 1999 from 74 domestic water-supply wells completed in the central High Plains aquifer .....

6. Map showing distribution of nitrate as nitrogen concentration in samples collected in 1999 form 74 domestic water-supply wells completed in the central High Plains aquifer .

7. Box plots showing concentrations of trace elements in samples collected in 1999 from 74 domestic water-supply wells completed in the central High Plains aquifer ...

8. Map showing radon concentration in samples collected in 1999 from 74 domestic water-supply wells completed in the central High Plains aquifer ....

9. Graph showing frequencies of detection of volatile organic compounds in samples collected in 1999 from 74 domestic water-supply wells completed in the central High Plains aquifer......

10. Map showing distribution of volatile organic compound detections in samples collected in 1999 from 74 domestic water-supply wells completed in the central High Plains aquifer. 
11. Graph showing frequencies of detection of pesticides in samples collected in 1999 from 74 domestic

water-supply wells completed in the central High Plains aquifer

Figures 12-13. Maps showing:

12. Distribution of pesticide detections in samples collected in 1999 from 74 domestic

water-supply wells completed in the central High Plains aquifer

13. Distribution of tritium concentration in samples collected in 1999 from 74 domestic

water-supply wells completed in the central High Plains aquifer

14. Box plots showing depths to tops of well screens, grouped by likely pre-1953 and post-1953 recharge

age dates for 74 domestic water-supply wells completed in the central High Plains aquifer

\section{TABLES}

1. Estimated water use for parts of Kansas and Oklahoma in 1995, and Texas in 1990 from the central

High Plains aquifer .7

2. Construction information for 74 sampled domestic water-supply wells completed in the central

High Plains aquifer.

3. Laboratory analyses methods for analyzed water-quality constituents

4. Water-quality constituents analyzed in water samples collected in 1999 from 74 domestic water-supply wells completed in the central High Plains aquifer

5. Summary statistics for water properties, major ions, nutrients, organic carbon, and trace elements for samples collected in 1999 from 74 domestic water-supply wells completed in the central High Plains aquifer

6. Frequencies of ranges of radon concentration compared to underlying bedrock units for samples collected in 1999 from 74 domestic water-supply wells completed in the central High Plains aquifer .....

7. Occurrence of detectable concentration of pesticides in samples collected in 1999 from 74 domestic water-supply wells completed in the central High Plains aquifer

8. Frequencies of detection of volatile organic compounds and pesticides compared to ranges of nitrate-nitrogen and tritium concentration in samples collected in 1999 from 74 domestic water supply wells completed in the central High Plains aquifer 
CONVERSION FACTORS AND VERTICAL DATUM

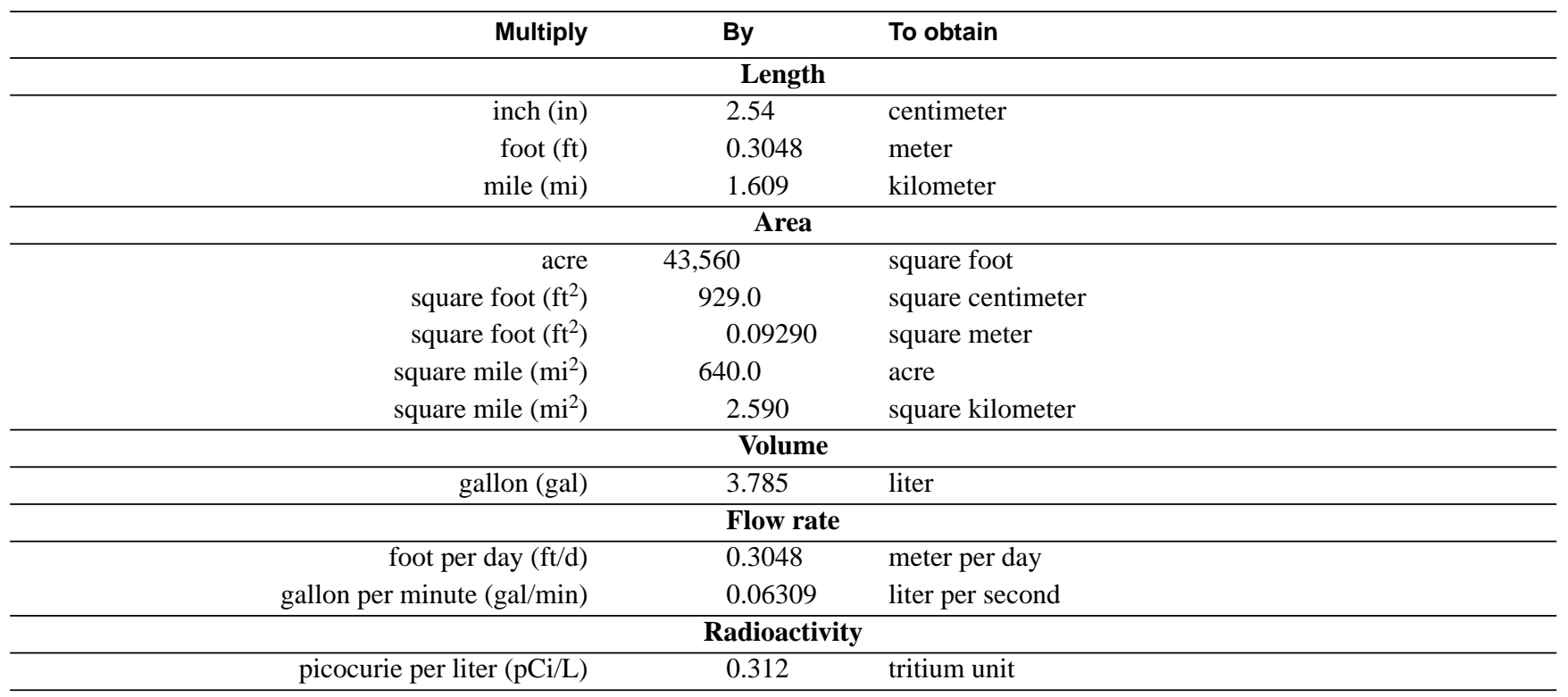

Temperature in degrees Celsius $\left({ }^{\circ} \mathrm{C}\right)$ may be converted to degrees Fahrenheit $\left({ }^{\circ} \mathrm{F}\right)$ as follows:

${ }^{\circ} \mathrm{F}=1.8{ }^{\circ} \mathrm{C}+32$

Temperature in degrees Fahrenheit $\left({ }^{\circ} \mathrm{F}\right)$ may be converted to degrees Celsius $\left({ }^{\circ} \mathrm{C}\right)$ as follows:

$$
{ }^{\circ} \mathrm{C}=\left({ }^{\circ} \mathrm{F}-32\right) / 1.8
$$

Sea level: In this report, "sea level" refers to the National Geodetic Vertical Datum of 1929 (NGVD of 1929)--a geodetic datum derived from a general adjustment of the first-order level nets of both the United States and Canada, formerly called Sea Level Datum of 1929.

Specific conductance is given in microsiemens per centimeter at 25 degrees Celsius $(\mu \mathrm{S} / \mathrm{cm}$ at 25 $\left.{ }^{\circ} \mathrm{C}\right)$.

Concentrations of chemical constituents in water are given either in milligrams per liter $(\mathrm{mg} / \mathrm{L})$ or micrograms per liter $(\mu \mathrm{g} / \mathrm{L})$. 
VIII CONTENTS 


\title{
Ground-Water Quality in the Central High Plains Aquifer in Colorado, Kansas, New Mexico, Okla- homa, and Texas, 1999
}

\author{
By Mark F. Becker, Breton W. Bruce, Larry M. Pope, and William J. Andrews
}

\section{ABSTRACT}

A network of 74 randomly distributed domestic water-supply wells completed in the central High Plains aquifer was sampled and analyzed from April to August 1999 as part of the High Plains Regional Ground-Water Study conducted by the U. S. Geological Survey National Water-Quality Assessment Program to provide a broad-scale assessment of the ground-water-quality in this part of the High Plains aquifer.

Water properties were relatively consistent across the aquifer, with water being alkaline and well oxidized. Water was mostly of the calcium and magnesium-bicarbonate type and very hard. Sulfate concentrations in water from three wells and chloride concentration in water from one well exceeded Secondary Maximum Contaminant Levels. Fluoride concentration was equal to the Maximum Contaminant Level in one sample. Nitrate concentrations was relatively small in most samples, with the median concentration of 2.3 milligrams per liter. Dissolved organic carbon concentration was relatively low, with a median concentration of 0.5 milligram per liter. The Maximum Contaminant Level set by the U.S. Environmental Protection Agency for nitrate as nitrogen of 10 milligrams per liter was exceeded by water samples from three wells. Most samples contained detectable concentrations of the trace elements aluminum, arsenic, barium, chromium, molybdenum, selenium, zinc, and uranium. Only a few samples had trace element concentrations exceeding Maximum Contaminant Levels. Fifty-five of the samples had radon concentrations exceeding the proposed Maximum Contaminant Level of 300 picocuries per liter. The greatest radon concentrations were detected where the
Ogallala Formation overlies sandstones, shales and limestones of Triassic, Jurassic, or Cretaceous age.

Volatile organic compounds were detected in 9 of 74 samples. Toluene was detected in eight of those nine samples. All volatile organic compound concentrations were substantially less than Maximum Contaminant Levels. Detections of toluene may have been artifacts of the sampling and analytical processes.

Pesticides were detected in 18 of the 74 water samples. None of the pesticide concentrations exceeded Maximum Contaminant Levels. The most frequently detected pesticides were atrazine and its metabolite deethylatrazine, which were detected in water from 15 and 17 wells, respectively. Most of the samples with a detectable pesticide had at least two detectable pesticides. Six of the samples had more than two detectable pesticides.

Tritium concentrations was greater than 0.5 tritium unit in 10 of 51 samples, indicating recent recharge to the aquifer. Twenty-one of the samples that had nitrate concentrations greater than 4.0 milligrams per liter were assumed to have components of recent recharge. Detection of volatile organic compounds was not associated with those indicators of recent recharge, with most of volatile organic compounds being detected in water from wells with small tritium and nitrate concentrations. Detection of pesticides was associated with greater tritium or nitrate concentrations, with 16 of the 18 wells producing water with pesticides also having tritium or nitrate concentrations indicating recent recharge.

\section{INTRODUCTION}

Knowledge of the quality of the Nation's water resources is important because of the implications to 
human and aquatic health and substantial costs associated with decisions involving land and water management, conservation, and regulation. In 1991, the U.S. Geological Survey (USGS) began full implementation of the National Water-Quality Assessment (NAWQA) Program. The long-term goals of the NAWQA program are to describe the status and trends in the quality of the Nation's surface- and ground-water resources and determine the natural and anthropogenic factors affecting water quality (Gilliom and others, 1995). More than 50 major river basins or aquifer systems will be investigated by the NAWQA Program. Together these basins and aquifer systems include water resources supplying more than 60 percent of the population and encompassing about one-half of the land area in the conterminous United States.

The High Plains Regional Ground-Water Study, begun under the NAWQA Program in October 1998, is a modification of the traditional NAWQA design in that ground-water is the primary focus of the study (Dennehy, 2000). The High Plains aquifer is a nationally important water resource that underlies about 174,000 square miles in parts of eight western states (fig. 1). About 27 percent of the irrigated land and 30 percent of the land irrigated with ground water in the United States overlie the High Plains aquifer (Dennehy, 2000). Due to the large areal extent of the High Plains aquifer, three geographic regions have been delineated for study: the northern High Plains (96,500 square miles); central High Plains (48,500 square miles); and southern High Plains $(29,000$ square miles) (fig. 1).

This report is part of a comprehensive waterquality assessment over the entire High Plains aquifer. The central High Plains aquifer is the focus of the study described in this report. The part of the central High Plains aquifer that is presented in this report extends over an area of about 38,000 square miles in parts of Colorado, Kansas, New Mexico, Oklahoma, and Texas (fig. 2).

\section{Purpose and Scope}

The purpose of this report is to describe the ground-water quality of the central High Plains aquifer in parts of Colorado, Kansas, New Mexico, Oklahoma, and Texas. Water samples collected during AprilAugust 1999 from 74 randomly distributed domestic water-supply wells in the central High Plains aquifer were analyzed to evaluate ground-water quality. Water samples from each well were analyzed for 186 constituents including: water properties, major ions, nutrients, dissolved organic carbon, trace elements, radon, volatile organic compounds, pesticides, and tritium. Many of these constituents are regulated in public drinking-water supplies by the U.S. Environmental Protection Agency (USEPA) under the Safe Water Drinking Act. The study area extended from about Goodland, Kansas, south to Amarillo, Texas (figs. 1 and 2).

\section{Acknowledgments}

The authors thank all who allowed access to sample their wells; Cristi Hansen and Michael and Carol Carlson, USGS, Kansas District; and Martin Schneider and Marty Phillips of the USGS Woodward, Oklahoma Field Office for working under difficult conditions to collect samples.

\section{DESCRIPTION OF STUDY AREA}

The study area for this report encompasses about 38,000 square miles that includes parts of southeastern Colorado, southwestern Kansas, northeastern New Mexico, northwestern Oklahoma, and northwestern Texas. Study area boundaries are restricted to the saturated area of the central High Plains aquifer extending from slightly north of the Arkansas River in Kansas to slightly south of the Canadian River in Texas. The western, southwestern, and eastern boundaries in the rest of the study area are formed by the erosional extent of the aquifer. The eastern boundary extends to about 30 miles east of Dodge City, Kansas, where the Ogallala Formation thins and grades into younger sediments.

\section{Physiography and Geology}

Most of the study area is in the Great Plains physiographic province (Fenneman, 1928). Flat to gently rolling terrain covers much of the study area (Dennehy, 2000), with escarpments located adjacent to major drainages. Pleistocene- and Holocene-age terrace deposits occur on the sides of the major alluvial valleys, opposite of the prevailing winds. Uncultivated areas consist of grasslands, with shrubs and trees adjacent to and within stream valleys. The study area 


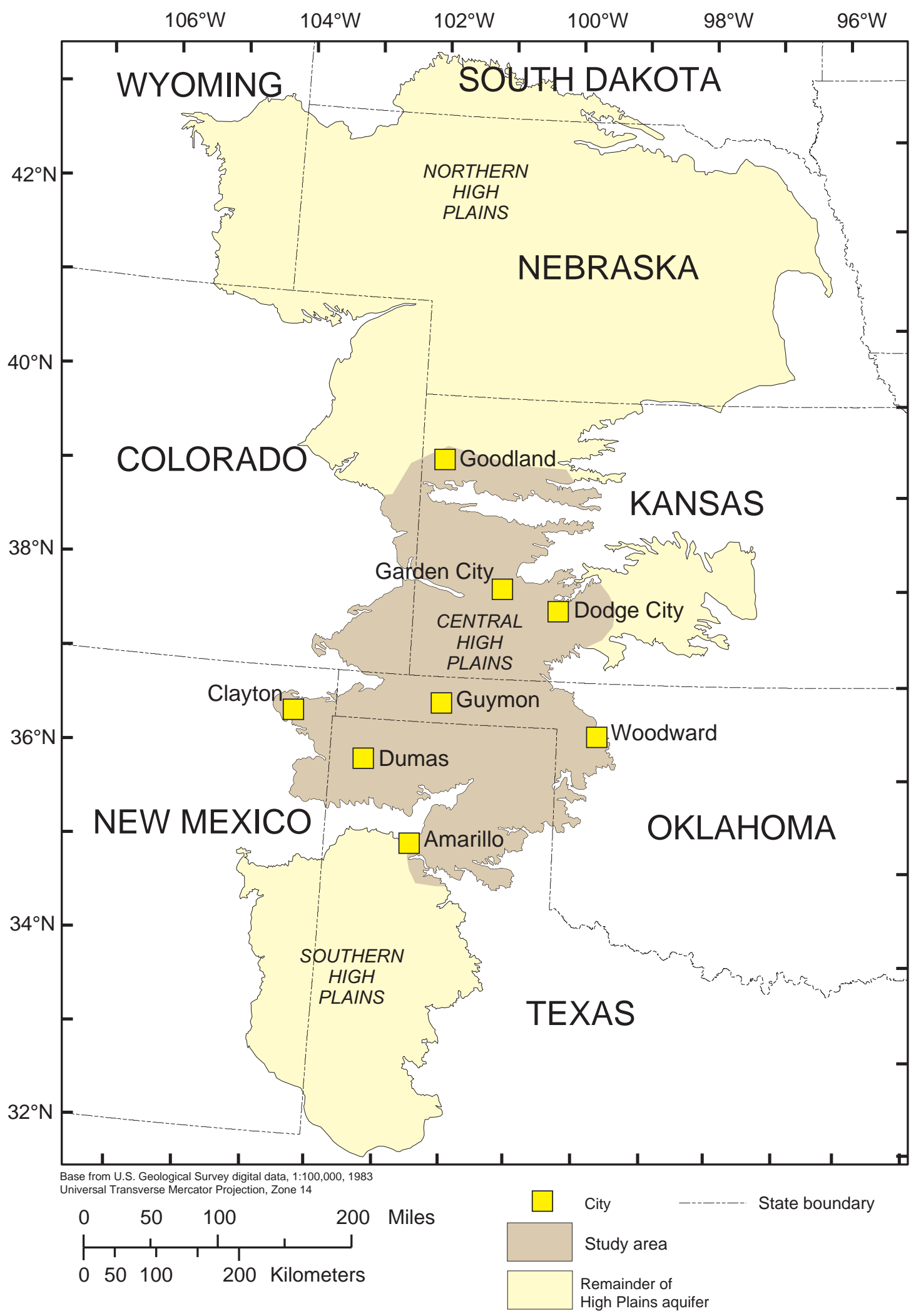

Figure 1. Location of study area. 


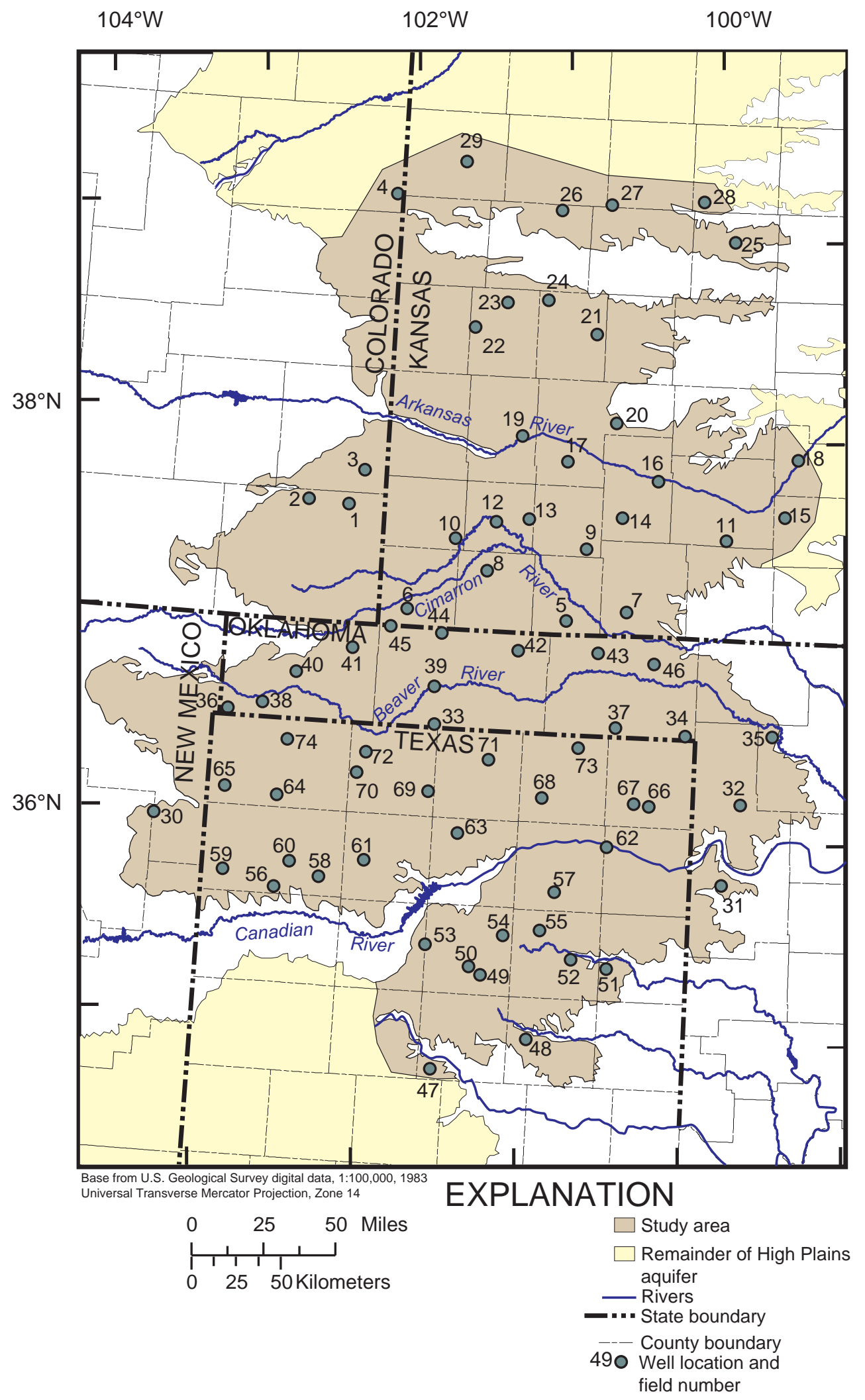

Figure 2. Locations of 74 domestic water-supply wells sampled for assessment of ground-water quality in the central High Plains aquifer, 1999. 
is semi-arid, receiving an average of 16-20 inches of precipitation annually (Weeks and others, 1988). More detailed descriptions of the physiography and geology of the area are in Gutentag and others (1984).

\section{Hydrogeology}

The central High Plains aquifer consists of sediments of varying ages and compositions. The Ogallala Formation, which is primarily Pliocene in age, is the largest hydrogeologic unit in the aquifer (Smith, 1940; Gutentag and others, 1981; Gutentag and others, 1984). The aquifer consists primarily of unconsolidated clay, silt, sand, and gravel with scattered zones cemented by calcium carbonate, known as caliche. Some parts of the aquifer include alluvial and windblown deposits of Pleistocene and Holocene age (Smith, 1940; Gutentag and others, 1984). Some of these younger sediments are in hydraulic connection with the Ogallala Formation and in some cases the contact between the Ogallala Formation and younger sediments is not easily identified. Therefore, in this report sediments of the Ogallala Formation or younger are referred to as the central High Plains aquifer.

Wells completed in the central High Plains aquifer support intensive agriculture from western Kansas to the Texas panhandle, as well as rural domestic and municipal drinking-water supplies. Gutentag and others (1984) reported that the thickness of the Ogallala Formation in the study area ranges from 0 to 550 feet. Hart and others (1976) reported that the maximum thickness of the aquifer in Oklahoma exceeded 650 feet. One of the wells sampled for this study indicates the thickness of the Ogallala Formation in Texas is greater than 700 feet.

In 1999, depth to the water table in the central High Plains aquifer ranged from less than one foot to more than 500 feet with a median of about 165 feet (V.L. McGuire, U.S. Geological Survey, written commun., 2001). Water levels in parts of the aquifer have declined from 10 to more than 100 feet since irrigation began in the 1940s (Dennehy, 2000). The regional hydraulic gradient in the central High Plains aquifer indicates that ground-water movement is generally from west to east.

Well yields vary depending on the saturated thickness, specific yield, and hydraulic conductivity of the aquifer. In the central High Plains, drillers logs have reported yields in excess of 2,000 gallons per minute for newly-completed irrigation wells. Aquifer depletion has led to decreased well yields in some areas. The additional lift required to pump from greater water-table depths reduces the pump capacities. Saturated thickness, the distance from the water table to the base of the aquifer, ranged from 0 to more than 600 feet in 1997 in the central High Plains aquifer (McGuire and Fischer, 1999). Specific yield, the ratio of the volume of water that will drain from a given volume of saturated rock, ranges from 10 to 20 percent (Gutentag and others, 1984), averaging about 16 percent (Luckey and Becker, 1999). Hydraulic conductivity is the rate at which water can move through a unit volume of the aquifer material per unit time at a unit gradient. Estimated hydraulic conductivities of the aquifer range from 25 to 100 feet per day (Gutentag and others, 1984), averaging 51 feet per day (Luckey and Becker, 1999).

Natural recharge to the aquifer from precipitation is variable both temporally and spatially. Local precipitation, soils characteristics, proportions of surface runoff, and land-use control the amount of recharge to the aquifer. Estimates of the mean annual potential ground-water recharge range from 0.05 to 1.85 inches per year (Gutentag and others, 1984).

\section{Land and Water Use}

The study area is sparsely populated with economic activity dominated by agriculture. Estimated population in the study area in 1998 was about 480,000. Amarillo, Texas, is the largest city in the study area, with a population of 217,000 in 2000 (U.S. Census Bureau, 2002). Most counties in the study area have estimated populations less than 5,000 (U.S. Census Bureau, 2000). Agriculture is the primary economic activity, followed by natural gas and petroleum production, and related support industries. As of 1995, land-use in the study area (fig. 3) was approximately 56 percent rangeland, 41 percent cropland, and 3 percent other uses (U.S. Geological Survey, 2000). Wheat is the primary crop in the study area, followed by corn and sorghum (U.S. Department of Commerce, 1949-92). Lesser crops include hay, other small grains, and miscellaneous crops.

Irrigated agriculture was responsible for 95 percent of the water use from the central High Plains aquifer in the study area in 1995 (Tortorelli, 2000; Dee Lurry and Joan Kenny, U.S. Geological Survey, 


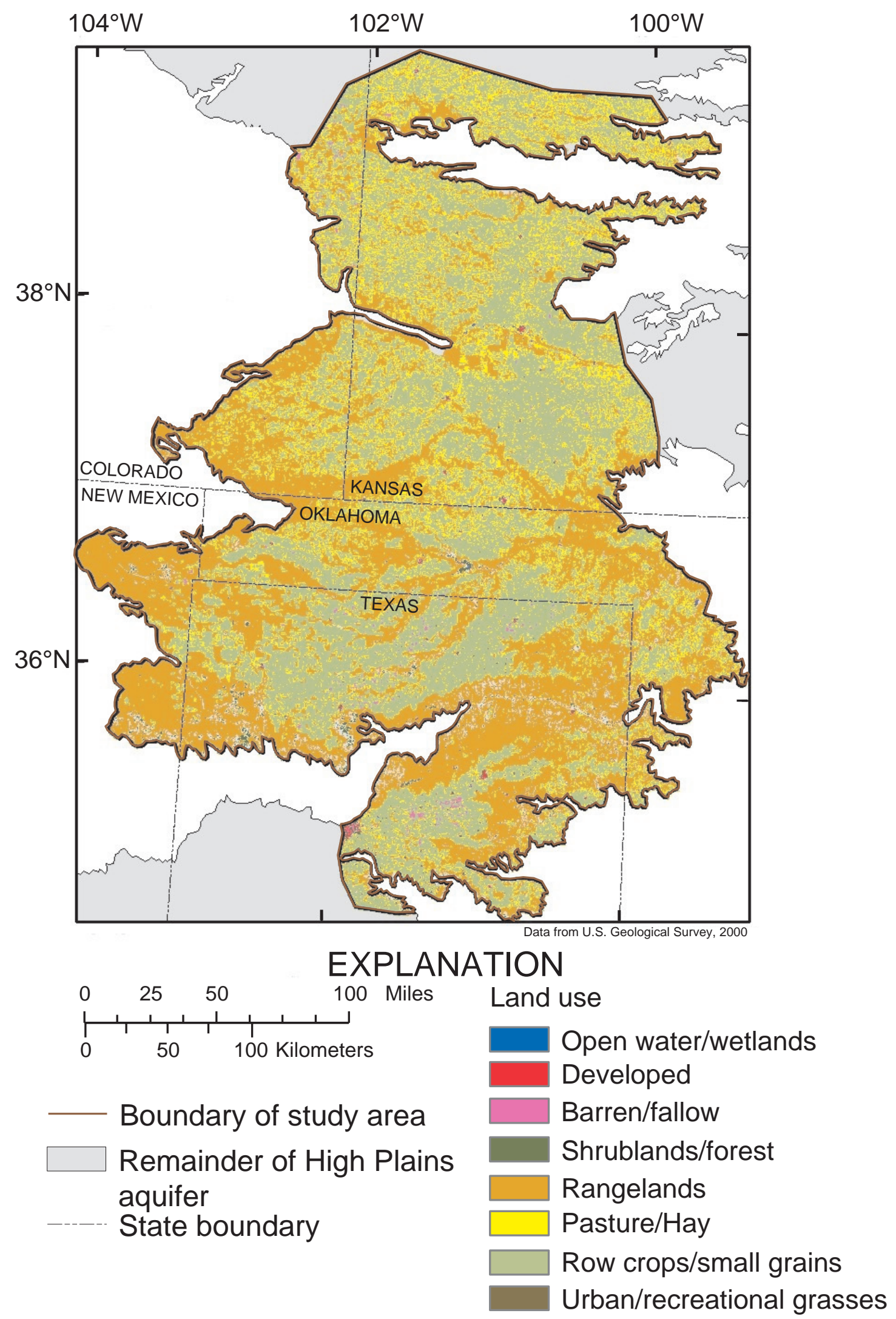

Figure 3. Land use over the central High Plains aquifer, 1995. 
Table 1. Estimated water use for parts of Kansas and Oklahoma in 1995, and Texas in 1990 from the central High Plains aquifer (Kenny, 1999; Tortorelli, 2000; and Lurry, 1994)

[values are in the millions of gallons per day; <, less than; numbers in parentheses are percentages of total water use]

\begin{tabular}{lrrrrrrr}
\hline State & Irrigation & $\begin{array}{c}\text { Public } \\
\text { supply }\end{array}$ & Livestock & $\begin{array}{c}\text { Public } \\
\text { power } \\
\text { supply }\end{array}$ & $\begin{array}{c}\text { Domestic } \\
\text { and } \\
\text { commercial }\end{array}$ & $\begin{array}{c}\text { Industrial } \\
\text { and } \\
\text { mining }\end{array}$ & Total \\
\hline Kansas & $1,961(97)$ & $18(1)$ & $27(1)$ & $2(<1)$ & $4(<1)$ & $7(<1)$ & 2,028 \\
Oklahoma & $637(95)$ & $11(2)$ & $19(3)$ & $0(0)$ & $1(<1)$ & $1(<1)$ & 669 \\
Texas & $1,464(95)$ & $20(1)$ & $17(1)$ & $0(0)$ & $1(<1)$ & $41(3)$ & 1,543 \\
\hline
\end{tabular}

written commun., 2000). In Kansas and Oklahoma, the primary uses of water, following irrigation, are livestock and public supply. In the Texas part of the study area, the order of use is irrigation, industrial supply, public supply, and livestock (table 1). The City of Amarillo, Texas, and associated industrial water use are the primary source of differences in the proportions of minor water uses between the three states listed in table 1.

\section{METHODS}

The study design for the assessment of groundwater quality in the central High Plains aquifer followed published guidelines developed for the NAWQA program (Gilliom and others, 1995; Lapham and others, 1995). The central High Plains Aquifer study area boundaries (fig. 2) outline an area of relatively homogeneous natural features and land uses. Delineation of the study area boundaries was based on work done for the Regional Aquifer-System Analysis (RASA) program (Sun and Johnston, 1994; Gutentag and others, 1984).

\section{Well Selection}

Within the central High Plains aquifer, groundwater sampling locations were determined using a grid-based random site-selection computer program (Scott, 1990). To ensure an equal-area randomized assessment of ground-water quality, 259 random sampling areas were identified over the entire extent of the High Plains aquifer. Seventy-four of the 259 sampling areas were within the boundaries of the central High Plains aquifer. One primary and one alternate site were randomly selected in each of the 74 selected areas. The average distance between primary sites was about 22 miles. Potential sampling locations represented a density of one primary site for each 500 square miles of the study area. Alternate sites were located if no well suitable for sampling could be located near the primary site. A well was considered suitable for sampling if: 1) it was within a 4-mile radius of the randomly selected site; 2 ) it was a domestic well that was actively being used as a household drinking-water supply; 3 ) it could be determined from a driller's log or other means that the well was completed in the central High Plains aquifer; 4) information could be obtained about well construction, including well depth, screened interval, and casing information; and 5) it was possible to collect a water sample prior to any water treatment device or storage tank. At 11 of the 74 primary sites, no domestic wells fitting these criteria could be located. Acceptable wells were chosen at the alternate sites for these 11 locations. Figure 2 shows the distribution of the 74 domestic wells sampled in the central High Plains aquifer in 1999. Well screen depths ranged from 34 to 706 feet below land surface (table 2). Water levels ranged from 14 to 416 feet below land surface (table 2), with a median depth of 150 feet. 
Table 2. Construction information for 74 sampled domestic water-supply wells completed in the central High Plains aquifer [depths are in feet below land surface; --, no data]

\begin{tabular}{|c|c|c|c|c|c|c|}
\hline \multirow[b]{2}{*}{$\begin{array}{c}\text { Field } \\
\text { well } \\
\text { number }\end{array}$} & \multirow[b]{2}{*}{ Station number } & \multirow[b]{2}{*}{ State } & \multirow[b]{2}{*}{$\begin{array}{l}\text { Data of well } \\
\text { construction }\end{array}$} & \multicolumn{3}{|c|}{ Screened interval } \\
\hline & & & & $\begin{array}{l}\text { Depth to top of } \\
\text { well screen }\end{array}$ & $\begin{array}{l}\text { Depth to bottom of } \\
\text { well screen }\end{array}$ & $\begin{array}{c}\text { Depth to } \\
\text { water }\end{array}$ \\
\hline 1 & 373507102162001 & Colorado & $9 / 20 / 1978$ & 165 & 200 & 177 \\
\hline 2 & 373559102314901 & Colorado & $9 / 15 / 1974$ & 100 & 240 & 177 \\
\hline 3 & 374535102110301 & Colorado & $12 / 2 / 1966$ & 176 & 196 & 176 \\
\hline 4 & 390830102052001 & Colorado & $6 / 10 / 1986$ & 150 & 170 & 90 \\
\hline 5 & 370358100510301 & Kansas & $1 / 5 / 1985$ & 220 & 265 & 169 \\
\hline 6 & 370458101514401 & Kansas & $4 / 16 / 1976$ & 90 & 150 & 89 \\
\hline 7 & 370724100281601 & Kansas & 3/9/1982 & 170 & 210 & 130 \\
\hline 8 & 371738101220301 & Kansas & $4 / 10 / 1985$ & 310 & 360 & 206 \\
\hline 9 & 372534100443501 & Kansas & $7 / 24 / 1992$ & 280 & 380 & 259 \\
\hline 10 & 372649101344701 & Kansas & 9/6/1985 & 342 & 382 & 225 \\
\hline 11 & 372956099512201 & Kansas & 8/8/1989 & 250 & 290 & 205 \\
\hline 12 & 373229101193201 & Kansas & $12 / 1 / 1989$ & 263 & 303 & 196 \\
\hline 13 & 373345101070801 & Kansas & $3 / 16 / 1994$ & 380 & 480 & 350 \\
\hline 14 & 373527100312701 & Kansas & -- & 246 & 286 & 137 \\
\hline 15 & 373732099291201 & Kansas & $10 / 26 / 1993$ & 90 & 110 & 63 \\
\hline 16 & 374650100181901 & Kansas & $10 / 29 / 1979$ & 147 & 207 & 46 \\
\hline 17 & 375129100532301 & Kansas & 7/30/1988 & 299 & 339 & 159 \\
\hline 18 & 375447099245001 & Kansas & 10/7/1991 & 40 & 60 & 15 \\
\hline 19 & 375828101111801 & Kansas & $9 / 11 / 1989$ & 315 & 355 & 62 \\
\hline 20 & 380331100352801 & Kansas & 4/7/1979 & 45 & 65 & 28 \\
\hline 21 & 382947100443201 & Kansas & $7 / 15 / 1986$ & 115 & 135 & 85 \\
\hline 22 & 383008101315601 & Kansas & 8/4/1982 & 155 & 175 & 127 \\
\hline 23 & 383758101195801 & Kansas & $5 / 12 / 1994$ & 190 & 210 & 158 \\
\hline 24 & 383919101040101 & Kansas & $9 / 3 / 1987$ & 176 & 196 & 165 \\
\hline 25 & 385904099522201 & Kansas & 10/7/1997 & 72 & 112 & 61 \\
\hline 26 & 390622101003201 & Kansas & $8 / 14 / 1987$ & 182 & 202 & 154 \\
\hline 27 & 390838100411701 & Kansas & 3/1988 & 198 & 208 & 110 \\
\hline 28 & 391044100051001 & Kansas & $11 / 11 / 1981$ & 69 & 89 & 42 \\
\hline 29 & 391921101385501 & Kansas & $8 / 26 / 1981$ & 230 & 250 & 157 \\
\hline 30 & 355916103215201 & New Mexico & $10 / 31 / 1986$ & 36 & 63 & 36 \\
\hline 31 & 354656099480301 & Oklahoma & $10 / 7 / 1983$ & 75 & 155 & 91 \\
\hline 32 & 361114099420501 & Oklahoma & 2/1/1979 & $74,114,154$ & $94,134,194$ & 83 \\
\hline 33 & 363057101384701 & Oklahoma & $12 / 5 / 1989$ & 280 & 360 & 208 \\
\hline 34 & 363104100035501 & Oklahoma & $6 / 15 / 1981$ & 260 & 360 & 83 \\
\hline 35 & 363154099310401 & Oklahoma & $10 / 1 / 1996$ & 40 & 60 & 14 \\
\hline 36 & 363157102565601 & Oklahoma & 9/13/1994 & 180 & 225 & 169 \\
\hline
\end{tabular}


Table 2. Construction information for 74 sampled domestic water-supply wells completed in the central High Plains

\begin{tabular}{|c|c|c|c|c|c|c|}
\hline \multirow[b]{2}{*}{$\begin{array}{c}\text { Field } \\
\text { well } \\
\text { number }\end{array}$} & \multirow[b]{2}{*}{ Station number } & \multirow[b]{2}{*}{ State } & \multirow[b]{2}{*}{$\begin{array}{l}\text { Data of well } \\
\text { construction }\end{array}$} & \multicolumn{3}{|c|}{ Screened interval } \\
\hline & & & & $\begin{array}{l}\text { Depth to top of } \\
\text { well screen }\end{array}$ & $\begin{array}{l}\text { Depth to bottom of } \\
\text { well screen }\end{array}$ & $\begin{array}{c}\text { Depth to } \\
\text { water }\end{array}$ \\
\hline 37 & 363239100301801 & Oklahoma & 8/13/1988 & 260 & 320 & 175 \\
\hline 38 & 363427102440401 & Oklahoma & $9 / 26 / 1990$ & 220 & 240 & 115 \\
\hline 39 & 364219101394101 & Oklahoma & $11 / 6 / 1991$ & 140 & 200 & 76 \\
\hline 40 & 364411102321201 & Oklahoma & -- & 220 & 260 & 232 \\
\hline 41 & 365223102113001 & Oklahoma & 3/30/1996 & 260 & 300 & 88 \\
\hline 42 & 365422101083701 & Oklahoma & $4 / 17 / 1990$ & 210 & 270 & 88 \\
\hline 43 & 365445100381901 & Oklahoma & 9/19/1997 & 140 & 160 & 92 \\
\hline 44 & 365821101375301 & Oklahoma & $2 / 5 / 1996$ & 360 & 420 & 270 \\
\hline 45 & 365934101573001 & Oklahoma & $1 / 2 / 1997$ & 260 & 300 & 252 \\
\hline 46 & 365210100164501 & Oklahoma & $3 / 24 / 1986$ & 180 & 300 & 135 \\
\hline 47 & 344800101324901 & Texas & 1990 & 100 & 150 & 111 \\
\hline 48 & 345826100580501 & Texas & $7 / 1 / 1982$ & 85 & 95 & 58 \\
\hline 49 & 351656101161101 & Texas & -- & 460 & 500 & 368 \\
\hline 50 & 351914101204401 & Texas & $8 / 10 / 1972$ & 562 & 605 & 398 \\
\hline 51 & 352035100293301 & Texas & 1959 & 34 & 68 & 29 \\
\hline 52 & 352249100425401 & Texas & $10 / 5 / 1998$ & 80 & 150 & 87 \\
\hline 53 & 352513101372101 & Texas & 11/13/1996 & 590 & 610 & 416 \\
\hline 54 & 352909101084001 & Texas & $5 / 19 / 1995$ & 380 & 490 & 377 \\
\hline 55 & 353110100550401 & Texas & $1 / 26 / 1971$ & $427,455,497$ & $437,475,520$ & 359 \\
\hline 56 & 353941102350201 & Texas & $11 / 3 / 1981$ & 320 & 331 & 316 \\
\hline 57 & 354248100501501 & Texas & $7 / 15 / 1986$ & 200 & 260 & 385 \\
\hline 58 & 354331102183601 & Texas & 12/31/1994 & 530 & 550 & 404 \\
\hline 59 & 354348102543601 & Texas & 6/10/1994 & 380 & 400 & 133 \\
\hline 60 & 354728102295901 & Texas & 4/1/1986 & 261 & 280 & 38 \\
\hline 61 & 354918102020901 & Texas & -- & 664,700 & 688,706 & 330 \\
\hline 62 & 355701100313001 & Texas & $9 / 11 / 1975$ & 60 & 95 & 32 \\
\hline 63 & 355852101274101 & Texas & $3 / 23 / 1982$ & 420 & 540 & 291 \\
\hline 64 & 360703102361901 & Texas & $6 / 28 / 1971$ & 308 & 468 & 316 \\
\hline 65 & 360838102560301 & Texas & 9/17/1993 & 220 & 240 & 167 \\
\hline 66 & 360944100162101 & Texas & $6 / 19 / 1985$ & 120 & 160 & 18 \\
\hline 67 & 361014100221001 & Texas & 9/12/1995 & 141 & 201 & 72 \\
\hline 68 & 361049100564901 & Texas & 6/1/1972 & 433 & 453 & 388 \\
\hline 69 & 361054101393601 & Texas & $1 / 23 / 1984$ & 380 & 460 & 290 \\
\hline 70 & 361517102065301 & Texas & $2 / 25 / 1986$ & 445 & 535 & 284 \\
\hline 71 & 362115101173901 & Texas & 10/17/1994 & 322 & 422 & 338 \\
\hline 72 & 362134102035101 & Texas & $5 / 1 / 1989$ & 360 & 415 & 286 \\
\hline 73 & 362615100435801 & Texas & $5 / 30 / 1991$ & 260 & 340 & 252 \\
\hline 74 & 362744102334901 & Texas & $9 / 14 / 1970$ & 181 & 221 & 118 \\
\hline
\end{tabular}


Table 3. Laboratory analyses methods for analyzed water-quality constituents

[GC/MS, gas chromatography/mass spectrometry; LC/MS, liquid chromatography/mass spectrometry; HPLC/DAD, high-performance liquid chromatography/diode array detection; HPLC/MS, high-performance liquid chromatography/mass spectrometry; UV, ultra violet; LCAA, liquid chromatography/atomic adsorption]

\begin{tabular}{|c|c|c|c|}
\hline $\begin{array}{c}\text { Constituent or constituent } \\
\text { group }\end{array}$ & $\begin{array}{l}\text { USGS schedule } \\
\text { or lab code }\end{array}$ & Analysis method & $\begin{array}{l}\text { Method } \\
\text { reference }\end{array}$ \\
\hline Major ions & 2750 & $\begin{array}{l}\text { Atomic absorption spectro- } \\
\text { metric }\end{array}$ & Fishman (1993) \\
\hline Nutrients & 2752 & Various methods & Fishman (1993) \\
\hline Dissolved organic carbon & 2085 & $\begin{array}{l}\text { UV-promoted persulfate } \\
\text { oxidation and infrared } \\
\text { spectrometry }\end{array}$ & Brenton and Arnett (1993) \\
\hline Trace elements & 2703 & $\begin{array}{l}\text { Atomic absorption spectro- } \\
\text { metric }\end{array}$ & Faires (1993) \\
\hline Radon & 1369 & Liquid scintillation & $\begin{array}{l}\text { American Society for Testing and } \\
\text { Materials (1996) }\end{array}$ \\
\hline Volatile organic compounds & 2020 & $\begin{array}{l}\text { Purge and trap capillary- } \\
\text { column GC/MS }\end{array}$ & Connor and others (1998) \\
\hline Pesticides & 2001 & $\begin{array}{l}\text { Solid phase extraction } \\
\text { using a sorbent cartridge } \\
\text { and GC/MS }\end{array}$ & Zaugg and others, (1995) \\
\hline Pesticide metabolites & LCAA & HPLC/DAD and HPLC/MS & Hostetle and Thurman (1999) \\
\hline Tritium & 1565 & $\begin{array}{l}\text { Electrolytic enrichment and } \\
\text { gas counting }\end{array}$ & Ostlund and Dorsey (1975) \\
\hline
\end{tabular}

\section{Sample Collection}

Procedures consistent with NAWQA sampling protocols described in Koterba and others (1995) were used to collect ground-water samples. Ground-water samples were collected and processed in a mobile water-quality laboratory. Existing submersible pumps along with the spigots, hydrants, or fittings installed near the wellhead were used for the sampling. All tubing and fittings attached to existing plumbing were stainless steel or Teflon and all sample bottles used in sample collection were made of pre-cleaned glass or plastic. All sample collection and preservation took place in plastic lined enclosures to prevent introduction of airborne contaminants. Sampling equipment was thoroughly cleaned between each site using tap water and Alconox soap, rinsed with deionized water, rinsed with methanol, and a final deionized water rinse. The exception to that procedure was the filter used for dissolved organic carbon, which was not rinsed with methanol.

Wells sampled were purged of several standing well volumes prior to sampling to ensure that stagnant water was not being sampled. Water purged from the wells was directed into an enclosed flow cell where water properties, including specific conductance, $\mathrm{pH}$, temperature, dissolved oxygen, and turbidity, were measured every five minutes. After the water property measurements were stable, water flow was redirected to an enclosed sampling chamber where water samples were collected for analysis.

Once collected, samples were shipped to the appropriate laboratory for analysis. Time sensitive samples such as radon and nutrients were shipped to the laboratory within 12 hours of being collected. Analyses were performed at the USGS National Water-Quality Laboratory in Lakewood, Colorado. Table 3 lists references for analytical methods used for all analyses. 


\section{Quality Control}

Quality-control samples are collected and analyzed to evaluate the degree of accuracy, precision, and bias of environmental samples. Quality-control samples analyzed for this study consisted of four types of blanks, replicate environmental samples, and environmental-matrix spike samples. In addition to quality-control samples submitted from the field, the USGS National Water-Quality Laboratory runs set blanks, duplicates, and spikes with each analytical run.

\section{Blanks}

Blank samples test for bias from introduction of contaminants to environmental samples. The blank source solution consisted of organic-free or inorganicfree waters prepared and tested by the USGS National Water Quality Laboratory and the USGS Quality of Water Service Unit for the NAWQA Program. Four types of blank samples were collected: source solution, equipment, field, and trip.

Source-solution blanks document the purity of the blank solution used for field and equipment blanks. Toluene was the only volatile organic compound detected in the five source-solution blank samples.

Two equipment blanks were collected prior to the collection of the first environmental samples to determine if the equipment or sample collection process would bias the data.

At the time environmental samples were collected, a total of eight (six were analyzed for volatile organic compounds) field blanks were collected at regular intervals on site to determine if sample contamination occurred from equipment decontamination, contamination of the vehicle, or data-collection methods in the field. Field blanks were taken on site following the collection of the environmental sample and cleaning of the equipment. Field blank samples were collected by pumping blank water through all decontaminated sampling equipment and processing the samples using the same protocols for the environmental samples. Equipment and field blank samples were analyzed for concentrations of major ions, nutrients, dissolved organic carbon, trace elements, volatile organic compounds, and pesticides. Aluminum concentrations in the environmental samples ranged from less than 1.0 to 6.2 micrograms per liter. Aluminum concentrations in field blank samples ranged from less than 1.0 to 4.8 micrograms per liter.
Dissolved organic carbon was detected in seven of eight field blank samples at concentrations ranging from less than 0.1 to 6.6 milligrams per liter. The concentration of dissolved organic carbon in environmental samples ranged from 0.2 to 2.0 milligrams per liter. Some of the contamination by organic carbon may have been caused by residues of Alconox soap or traces of methanol used to rinse field equipment between samples. Orthophosphate was detected in three of eight field blanks, ranging in concentrations from less than 0.01 to 0.021 milligram per liter. Orthophosphate concentrations in the environmental samples ranged from less than 0.01 to 0.052 milligram per liter. Toluene was detected in all six field blanks analyzed for volatile organic compounds in similar concentrations ( 0.05 to 0.16 microgram per liter) to those detected in environmental samples.

Trip blanks were sealed vials of purified water prepared in the laboratory, transported into the field, and shipped to the lab for analysis to assess the possibility of contamination during transport or shipping of samples to the lab. Trip blanks were analyzed for volatile organic compounds. Toluene was detected in three of the five trip blanks.

Data from blank samples indicate that sampling procedures and decontamination of equipment caused nominal contamination of water samples by a few constituents. Aluminum, dissolved organic carbon, orthophosphate, and toluene were the only constituents detected in the field blank samples. Detections of all four constituents in both environmental samples and equipment blank samples indicate possible positive bias of concentrations of those constituents in the environmental samples. Toluene was detected in 35 of 221 set blank samples analyzed at the National Water Quality Laboratory at concentrations ranging from 0.0004 to 0.052 microgram per liter (Donna Rose, U.S. Geological Survey, written commun., 2002). Detections of greater concentrations of toluene in trip blanks and field blank samples may be due to environmental contamination at the time of sampling and during shipment.

\section{Replicates}

Replicate quality-control samples are used to evaluate variability in water-quality data due to analytical or sample collection processes. Replicate samples were collected sequentially, following the collection of environmental samples, and were analyzed for 
concentrations of major ions, nutrients, dissolved organic carbon, trace elements, and radon. Replication of analyses of volatile organic compounds and pesticides was achieved through analyses of environmental-matrix spikes. Precision is calculated from two replicate samples, expressed as relative percent difference (RPD):

$$
R P D=\frac{\left|C_{1}-C_{2}\right|}{\left(\frac{\left(C_{1}+C_{2}\right)}{2}\right)} \times 100
$$

where $\mathrm{C}_{1}$ is the larger of the two values and $\mathrm{C}_{2}$ is the smaller of the two values.

If the estimated concentration of a constituent in one sample of a pair was less than the analytical reporting level, the reporting level was substituted for that concentration to calculate the RPD. If both constituent concentrations in the replicate pair were less than the reporting level, then the RPD was not calculated and the concentrations were assumed to be the same. Most of the RPD values were less than 2 percent. For many constituent concentrations, relatively small differences in replicate concentrations led to large RPD values, but those differences were not substantial. Replicate samples generally indicated an acceptable degree of reproducibility of results.

\section{Environmental-matrix spikes}

Environmental-matrix spikes are environmental samples collected and spiked in the field with a known quantity of analytes. Analytical recoveries of the spiked compounds are expressed in percentages of the expected concentrations. Environmental-matrix spikes test analytical recoveries and matrix interferences of volatile organic compounds and pesticides.

Mean percent recoveries of volatile organic compounds were biased low, with the mean percent recovery for all 85 compounds being 76 percent. Two of the 85 compounds had mean recoveries exceeding 100 percent. Mean recoveries ranged from 39 percent (carbon disulfide) to 145 percent (m,p-xylene). These relatively small percent recoveries indicate that the methods used to collect, preserve, and analyze these compounds may somewhat underestimate environmental concentrations of those compounds.

Data from 18 environmental-matrix spikes indicated that for most pesticides, analytical results were close to true concentrations. Of the 47 pesticides in the spike mixture, 33 of 47 had mean percent recoveries between 90 and 110 percent. Deethylatrazine generally had recoveries less than 60 percent and poor analytical accuracy and as a result, all detections are reported as estimated concentrations. Four pesticides-DDE, pendimethalin, permethrin, and propargite had mean percent recoveries less than 70 percent. Six pesticides-alachlor, carbaryl, carbofuran, propanil, simazine, and tebuthiuron, had mean percent recoveries greater than 100 percent. Generally, the recovery of pesticides was close to the ideal of 100 percent. With the exception of deethylatrazine, reported concentrations for environmental samples are considered to be close to the true concentrations.

\section{GROUND-WATER QUALITY}

To evaluate ground-water quality of the central High Plains aquifer, water properties and chemical constituents were analyzed in water samples from 74 domestic water-supply wells completed in the aquifer (table 4, Appendix 1).

Maximum Contaminant Levels set by the USEPA for public water supplies are the primary standards of water quality referenced in this report. Those levels are set for water properties and dissolved constituents to prevent adverse effects on human health (Maximum Contaminant Level) or to prevent nuisances such as foul odors, staining, or usability of water (Secondary Maximum Contaminant Level) (U.S. Environmental Protection Agency, 2001a). These levels apply to public water supplies and are not enforceable for private domestic water supplies. These levels are, however, useful benchmarks for owners of private wells. Ground-water quality of the central High Plains aquifer will be described in the following sections in relation to Maximum Contaminant Levels and potential sources of the water-quality constituents.

\section{Water Properties}

Water properties are general indicators of the quality of water, which are readily measured in the field as samples are collected. Water properties measured at the time of sample collection were specific conductance, $\mathrm{pH}$, water temperature, turbidity, dissolved oxygen, and alkalinity (table 5). Specific 
Table 4. Water-quality constituents analyzed in water samples collected in 1999 from 74 domestic water-supply wells completed in the central High Plains aquifer

[USGS, U.S. Geological Survey; SC, analytical schedule code; LC, analytical laboratory code; N, nitrogen; P, phosphorous; pCi/L, picocurie per liter]

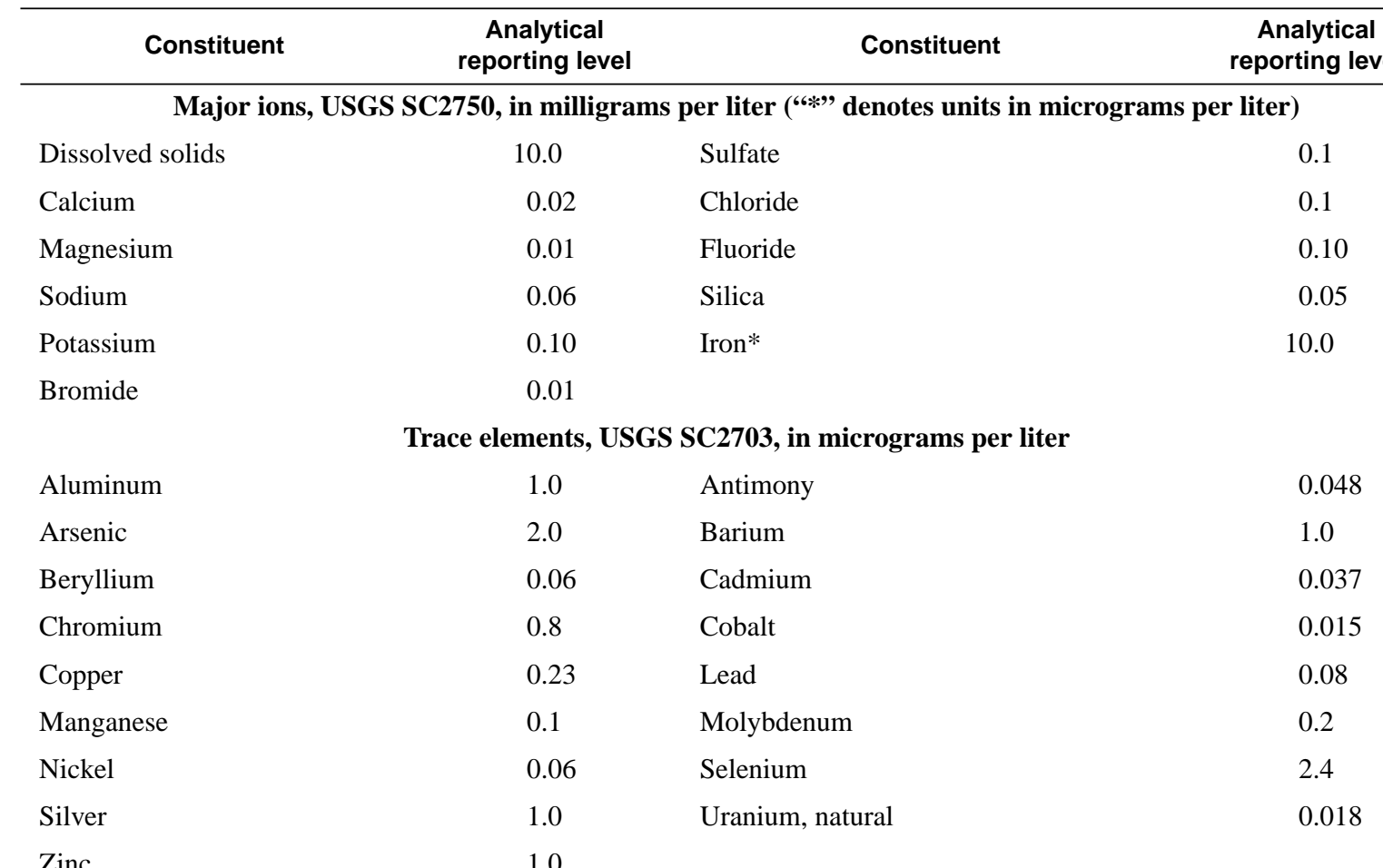

Nutrients, USGS SC2752; and dissolved organic carbon USGS SC2085, in milligrams per liter

Nitrogen, nitrite $\quad 0.01 \quad$ Nitrogen, ammonia + organic nitrogen 0.

$\begin{array}{llll}\text { Nitrogen, nitrite }+ \text { nitrate } & 0.05 & \text { Phosphorus } & 0.004\end{array}$

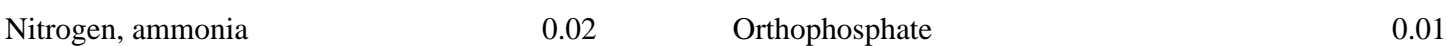

Dissolved organic carbon $\quad$.

Volatile organic compounds, USGS SC2090, in micrograms per liter

$\begin{array}{lclr}\text { 1,1,1,2-Tetrachloroethane } & 0.044 & 1,1,1 \text {-Trichloroethane } & 0.032 \\ \text { 1,1,2,2-tetrachloroethane } & 0.13 & 1,1,2 \text {-Trichloroethane } & 0.064 \\ \text { 1,1,2-Trichlorotrifluoroethane } & 0.032 & 1,1 \text {-Dichloroethane } & 0.066 \\ \text { 1,1-Dichloroehtylene } & 0.044 & 1,1 \text {-Dichloropropene } & 0.026 \\ \text { 1,2,3,4-Tetramethylbenzene } & 0.23 & 1,2,3,5 \text {-Tetramethylbenzene } & 0.2 \\ \text { 1,2,3-Trichlorobenzene } & 0.27 & 1,2,3 \text {-Trichloropropane } & 0.16 \\ \text { 1,2,3-Trimethylbenzene } & 0.12 & \text { 1,2,4-Trichlorobenzene } & 0.19 \\ \text { 1,2,4-Trimethylbenzene } & 0.056 & \text { 1,2-Dibromo-3-chloropropane } & 0.21 \\ \text { 1,2-Dibromoethane } & 0.036 & \text { 1,2-Dichlorobenzene } & 0.048 \\ \text { 1,2-Dichloroethane } & 0.13 & \text { 1,2-Dichloropropane } & 0.068 \\ \text { 1,3,5-Trimethylbenzene } & 0.044 & \text { 1,3-Dichlorobenzene } & 0.054 \\ & \text { Volatile organic compounds, SC2090, in micrograms per liter } & \text { 1,4-Dichlorobenzene } & 0.05 \\ \text { 1,3-Dichloropropane } & 0.12 & \text { 2-Butanone } & 1.6 \\ \text { 2,2-Dichloropropane } & 0.078 & \end{array}$


Table 4. Water-quality constituents analyzed in water samples collected in 1999 from 74 domestic water-supply wells completed in the central High Plains aquifer-Continued

\begin{tabular}{|c|c|c|c|}
\hline Constituent & $\begin{array}{c}\text { Analytical } \\
\text { reporting level }\end{array}$ & Constituent & $\begin{array}{c}\text { Analytical } \\
\text { reporting level }\end{array}$ \\
\hline 2-Chlorotoluene & 0.042 & 2-Hexanone & 0.7 \\
\hline 3-Chloropropene & 0.2 & 4-Chlorotoluene & 0.056 \\
\hline 4-Isopropyl-1-methylbenzene & 0.11 & 4-Methyl-2-pentanone & 0.37 \\
\hline Acetone & 5 & Acrylonitrile & 1.2 \\
\hline Benzene & 0.1 & Bromobenzene & 0.036 \\
\hline Bromochloromethane & 0.044 & Bromodichloromethane & 0.048 \\
\hline Bromoethene & 0.1 & Bromoform & 0.1 \\
\hline Bromomethane & 0.15 & Butylbenzene & 0.19 \\
\hline Carbon disulfide & 0.37 & Chlorobenzene & 0.028 \\
\hline Chloroethane & 0.12 & Chloroform & 0.052 \\
\hline Chloromethane & 0.25 & Dibromochloromethane & 0.18 \\
\hline Dibromomethane & 0.05 & Dichlorodifluoromethane & 0.14 \\
\hline Dichloromethane & 0.38 & Diethyl ether & 0.17 \\
\hline Diisopropyl ether & 0.098 & Ethyl methacrylate & 0.28 \\
\hline Ethyl tert-butyl ether & 0.054 & Ethylbenzene & 0.03 \\
\hline Hexachlorobutadiene & 0.14 & Hexachloroethane & 0.36 \\
\hline Isopropylbenzene & 0.032 & Methyl acrylate & 1.4 \\
\hline Methyl acrylonitrile & 0.57 & Methyl iodide & 0.21 \\
\hline Methyl methacrylate & 0.35 & Naphthalene & 0.25 \\
\hline Styrene & 0.042 & Tetrachloroethylene & 0.1 \\
\hline Tetrachloromethane & 0.088 & Tetrahydrofuran & 9 \\
\hline Toluene & 0.05 & Trichloroethylene & 0.038 \\
\hline Trichlorofluoromethane & 0.09 & Vinyl chloride & 0.11 \\
\hline cis-1,2-Dichloroethylene & 0.038 & cis-1,3-Dichloropropene & 0.09 \\
\hline $\mathrm{m}$ - and p- Xylene & 0.06 & n-Propylbenzene & 0.042 \\
\hline o-Ethyl toluene & 0.1 & o-Xylene & 0.06 \\
\hline sec-Butylbenzene & 0.048 & tert-Butyl methyl ether & 0.17 \\
\hline tert-Butylbenzene & 0.1 & tert-Pentyl methyl ether & 0.11 \\
\hline trans-1,2-Dichloroethylene & 0.032 & trans-1,3-Dichloropropene & 0.13 \\
\hline trans-1,4-Dichloro-2-butene & 0.7 & & \\
\hline \multicolumn{4}{|c|}{ Pesticides, USGS SC2001, in micrograms per liter } \\
\hline 2,6-diethylaniline & 0.003 & Acetochlor & 0.002 \\
\hline Alachlor & 0.002 & alpha-BHC & 0.002 \\
\hline Atrazine & 0.001 & Azinphos-methyl & 0.001 \\
\hline Benfluralin & 0.002 & Butylate & 0.002 \\
\hline \multicolumn{4}{|c|}{ Pesticides, USGS SC2001, in micrograms per liter } \\
\hline Carbaryl & 0.003 & Carbofuran & 0.003 \\
\hline Chlorpyrifos & 0.004 & cis-Permethrin & 0.005 \\
\hline Cyanazine & 0.004 & Dacthal & 0.002 \\
\hline
\end{tabular}


Table 4. Water-quality constituents analyzed in water samples collected in 1999 from 74 domestic water-supply wells completed in the central High Plains aquifer-Continued

\begin{tabular}{|c|c|c|c|}
\hline Constituent & $\begin{array}{c}\text { Analytical } \\
\text { reporting level }\end{array}$ & Constituent & $\begin{array}{c}\text { Analytical } \\
\text { reporting level }\end{array}$ \\
\hline Deethylatrazine & 0.002 & Diazinon & 0.002 \\
\hline Dieldrin & 0.001 & Disulfoton & 0.017 \\
\hline EPTC & 0.002 & Ethalfluralin & 0.004 \\
\hline Ethoprophos & 0.003 & Fonofos & 0.003 \\
\hline Lindane & 0.004 & Linuron & 0.002 \\
\hline Malathion & 0.005 & Metolachlor & 0.002 \\
\hline Metribuzin & 0.004 & Molinate & 0.004 \\
\hline Napropamide & 0.003 & p,p'-DDE & 0.006 \\
\hline Parathion & 0.004 & Parathion-methyl & 0.006 \\
\hline Pebulate & 0.004 & Pendimethalin & 0.004 \\
\hline Phorate & 0.002 & Prometon & 0.018 \\
\hline Propachlor & 0.007 & Propanil & 0.004 \\
\hline Propargite & 0.013 & Propyzamide & 0.003 \\
\hline Simazine & 0.005 & Tebuthiuron & 0.01 \\
\hline Terbacil & 0.007 & Terbufos & 0.013 \\
\hline Thiobencarb & 0.002 & Tri-allate & 0.001 \\
\hline Trifluralin & 0.002 & & \\
\hline \multicolumn{4}{|c|}{ Pesticide metabolites, LCAA, in micrograms per liter } \\
\hline Acetochlor OA & 0.05 & Acetochlor ESA & 0.05 \\
\hline Alachlor OA & 0.05 & Alachlor ESA & 0.05 \\
\hline Metolachlor OA & 0.05 & Metolachlor ESA & 0.05 \\
\hline \multicolumn{4}{|c|}{ Radionuclides and other constituents (units as noted)) } \\
\hline $\begin{array}{l}\text { Radon, USGS LC1369 in } \\
\mathrm{pCi} / \mathrm{L}\end{array}$ & 26 & Tritium, USGS LC1565 in $\mathrm{pCi} / \mathrm{L}$ & 1.0 \\
\hline
\end{tabular}


Table 5. Summary statistics for water properties, major ions, nutrients, organic carbon, and trace elements for samples collected in 1999 from 74 domestic water-supply wells completed in the central High Plains aquifer

$\left[<\right.$, signifies analytical reporting level; NTU, nephelometric turbidity units; $\mathrm{mg} / \mathrm{L}$, milligrams per liter; $\mu \mathrm{S} / \mathrm{cm}$, microsiemens per centimeter; ${ }^{\circ} \mathrm{C}$, degrees Celsius; $\mu \mathrm{g} / \mathrm{L}$, micrograms per liter; Maximum Contaminant Level, regulatory drinking-water standard set by the U.S. Environmental Protection Agency for public water supplies, *, Secondary Maximum Contaminant Level, non-regulatory drinking-water standard set by the U.S. Environmental Protection Agency for public water supplies; --, no data]

\begin{tabular}{|c|c|c|c|c|c|c|}
\hline Constituents & $\begin{array}{l}\text { Samples } \\
\text { collected }\end{array}$ & $\begin{array}{c}\text { Analytical } \\
\text { reporting } \\
\text { level }\end{array}$ & Minimum & Median & Maximum & $\begin{array}{c}\text { Maximum } \\
\text { Contami- } \\
\text { nant Level }\end{array}$ \\
\hline \multicolumn{7}{|c|}{ Water properties } \\
\hline Specific conductance, $25 \mathrm{C}$, in $\mu \mathrm{S} / \mathrm{cm}$ & 74 & 1 & 280 & 500 & 1,600 & -- \\
\hline $\mathrm{pH}$, in standard units & 74 & -- & 7.2 & 7.6 & 8.3 & $6.5-8.5^{*}$ \\
\hline Temperature, in ${ }^{\circ} \mathrm{C}$ & 74 & -- & 12 & 17 & 21 & -- \\
\hline Turbidity, in NTU & 73 & 0.01 & 0.07 & 0.29 & 11 & -- \\
\hline Dissolved oxygen, in mg/L & 74 & -- & 0.3 & 6.2 & 8.5 & -- \\
\hline Alkalinity as $\mathrm{CaCO}_{3}$, in $\mathrm{mg} / \mathrm{L}$ & 74 & 1 & 120 & 180 & 320 & -- \\
\hline \multicolumn{7}{|c|}{ Dissolved solids and major ions, in $\mathrm{mg} / \mathrm{L}$} \\
\hline Solids, residue on evaporation, $180^{\circ} \mathrm{C}$ & 73 & 10 & 180 & 330 & 1,100 & $500 *$ \\
\hline Calcium & 74 & 0.02 & 7.4 & 48 & 140 & -- \\
\hline Magnesium & 74 & 0.01 & 4.2 & 20 & 56 & -- \\
\hline Sodium & 74 & 0.06 & 6.8 & 29 & 280 & -- \\
\hline Potassium & 74 & 0.1 & $<0.1$ & 4.3 & 7.6 & -- \\
\hline Sulfate & 74 & 0.31 & 6.4 & 37 & 430 & $250 *$ \\
\hline Chloride & 74 & 0.29 & 3.0 & 16 & 260 & $250 *$ \\
\hline Fluoride & 74 & 0.1 & 0.3 & 1.1 & 4.0 & 4.0 \\
\hline Bromide & 74 & 0.01 & 0.04 & 0.12 & 1.7 & -- \\
\hline Silica & 74 & 0.09 & 14 & 30 & 61 & -- \\
\hline Hardness as $\mathrm{CaCO}_{3}$ & 74 & 0.5 & 82 & 200 & 500 & -- \\
\hline \multicolumn{7}{|c|}{ Nutrients and organic carbon, in $\mathrm{mg} / \mathrm{L}$} \\
\hline Nitrite & 74 & 0.01 & $<0.01$ & $<0.01$ & 0.01 & 1.0 \\
\hline Nitrate & 74 & 0.05 & $<0.05$ & 2.3 & 20 & 10 \\
\hline Ammonia & 74 & 0.02 & $<0.02$ & $<0.02$ & 0.04 & -- \\
\hline Ammonia+organic nitrogen & 74 & 0.1 & $<0.1$ & $<0.1$ & 1.0 & -- \\
\hline Phosphorus, total & 74 & 0.004 & $<0.004$ & 0.005 & 0.054 & -- \\
\hline Orthophosphate & 74 & 0.01 & $<0.01$ & 0.015 & 0.052 & -- \\
\hline Dissolved organic carbon & 74 & 0.1 & 0.2 & 0.5 & 2.0 & -- \\
\hline \multicolumn{7}{|c|}{ Trace elements, in $\mu \mathrm{g} / \mathrm{L}$} \\
\hline Aluminum & 74 & 1 & $<1$ & 3 & 6 & $50-200^{*}$ \\
\hline Antimony & 74 & 1 & $<1$ & $<1$ & $<1$ & 6 \\
\hline Arsenic & 74 & 1 & $<1$ & 2 & 9.7 & 50 \\
\hline Barium & 74 & 1 & 20 & 80 & 560 & 2000 \\
\hline Beryllium & 74 & 1 & $<1$ & $<1$ & $<1$ & 4 \\
\hline Cadmium & 74 & 1 & $<1$ & $<1$ & $<1$ & 5 \\
\hline Chromium & 68 & 1 & $<1$ & 1.1 & 5.2 & 100 \\
\hline Cobalt & 74 & 1 & $<1$ & $<1$ & $<1$ & -- \\
\hline
\end{tabular}


Table 5. Summary statistics for water properties, major ions, nutrients, organic carbon, and trace elements for samples collected in 1999 from 74 domestic water-supply wells completed in the central High Plains aquifer-Continued

\begin{tabular}{lcccccc}
\hline Constituents & $\begin{array}{c}\text { Samples } \\
\text { collected }\end{array}$ & $\begin{array}{c}\text { Analytical } \\
\text { reporting } \\
\text { level }\end{array}$ & Minimum & Median & Maximum & $\begin{array}{c}\text { Maximum } \\
\text { Contami- } \\
\text { nant Level }\end{array}$ \\
\hline Copper & 74 & 1 & $<1$ & $<1$ & 6.3 & 1300 \\
Iron & 74 & 10 & $<10$ & $<10$ & 38 & 300 \\
Lead & 74 & 1 & $<1$ & $<1$ & 2.3 & 0 \\
Manganese & 74 & 1 & $<1$ & $<1$ & 85 & $50^{*}$ \\
Molybdenum & 74 & 1 & $<1$ & 4.9 & 52 & -- \\
Nickel & 74 & 1 & $<1$ & $<1$ & 2.7 & -- \\
Selenium & 74 & 1 & $<1$ & 3 & 18 & 50 \\
Silver & 74 & 1 & $<1$ & $<1$ & $<1$ & $100^{*}$ \\
Uranium & 74 & 1 & $<1$ & 7.2 & 31 & -- \\
Zinc & 74 & 1 & $<1$ & 13 & 170 & 5000 \\
\hline
\end{tabular}

conductance is a measure of the ability of water to conduct electrical current. Greater dissolved ion concentration conducts greater current, so specific conductance is an indirect measurement of the amount of dissolved ionic substances in water. Specific conductances in the water samples ranged from 285 microsiemens per centimeter at 25 degrees Celsius to 1,060 microsiemens per centimeter at 25 degrees Celsius indicated that the water samples were relatively low in dissolved solids (table 5). The pH's of samples were near neutral to alkaline, but did not exceed Secondary Maximum Contaminant Levels of less than 6.5 or greater than 8.5 (table 5). The median water temperature was 17 degrees Celsius. Turbidity indirectly measures the amount of suspended particulate matter in water. As with water from most domestic wells, turbidities were relatively small in the water samples (table 5). The median dissolved oxygen concentration was 6.2 milligrams per liter, indicating that most of the aquifer is well-oxygenated (table 5). Alkalinity is the capacity of a filtered water sample to neutralize a strong acid, or the buffering capacity of a solution, and is expressed in milligrams per liter as calcium carbonate. Dissolution of carbonate minerals is typically the primary source of alkalinity and directly affects "hardness" of water. About 60 percent of the water samples had hardnesses greater than 180 milligrams per liter as calcium carbonate, which is classified as "very hard" (Hem, 1989, p. 159), potentially affecting performance of soaps and detergents and contributing calcitic or gypsiferous scales to pipes, water heaters, and boilers.

\section{Dissolved Solids and Major Ions}

Dissolved solids are an indicator of general water quality and the suitability of water for drinking, agricultural, and industrial use. Dissolved solids are the mass of solids per unit remaining when a filtered water sample is evaporated to dryness. The Secondary Maximum Contaminant Level of 500 milligrams per liter for dissolved solids was exceeded in 16 samples, with two samples having dissolved solids concentrations greater than 1,000 milligrams per liter. The standard for dissolved solids is set to minimize deposits in boilers, colored water, staining, and salty taste (U.S. Environmental Protection Agency, 2001a). Krothe and others (1982) reported that dissolved solids concentrations greater than 1,000 milligrams per liter occur in less than 3 percent of the area of the High Plains aquifer and that greatest dissolved solids concentrations generally occurs in the Texas portion of the aquifer. Krothe and others (1982) also reported that proportions of major ions are related to dissolved 
solids concentrations as follows: samples with dissolved solids concentrations less than 250 milligrams per liter are typically dominated by calcium and bicarbonate, samples with dissolved solids concentrations from 250 to 500 milligrams per liter are dominated by sodium and sulfate, and samples with dissolved solids concentrations greater than 500 milligrams per liter have mixed water chemistry. Three of the samples from the 74 wells (4 percent) had a dissolved solids concentration less than 250 milligrams per liter. Ratios between major ions in those samples were similar to those having dissolved solids concentrations between 250 and 500 milligrams per liter, except that the majority of those samples had somewhat greater chloride concentrations and lesser alkalinities (fig. 4). Samples with dissolved solids concentrations greater than 500 milligrams per liter tended to have greater proportions of sodium and potassium relative to calcium and increased proportions of chloride and sulfate (fig. 4), as described by Krothe and others (1982). Much of the central High Plains aquifer is underlain by sedimentary rocks of Permian or later ages that contain waters having dissolved solids concentrations greater than 500 milligrams per liter, due to sulfate enrichment from gypsum dissolution and/or sodium and chloride from seepage of diluted brines (Krothe and others, 1982; Irwin and Morton, 1969).

Calcium concentrations ranged from less than 10 to nearly 140 milligrams per liter (table 5 , fig. 5). Major sources of calcium include dissolution of carbonate minerals such as calcite and dolomite and gypsum. Caliche layers and interstitial carbonate cements in the sand and gravel layers in the central High Plains aquifer are composed primarily of calcite (Hart and others, 1976; Krothe and others, 1982). Dissolution of gypsum in the underlying units also is a contributor of calcium and sulfate (Hart and others, 1976).

Magnesium concentrations was generally onethird to one-half those of calcium in the water samples (table 5, fig. 5). Common sources of magnesium include dolomite, calcite with magnesium impurities, and a number of mafic minerals, which are likely to have been components of igneous and metamorphic rocks forming the ancestral Rocky Mountains, the source of most of the sediments forming the aquifer (Gutentag and others, 1984, p. 8).

Sodium concentrations ranged from less than 7 to nearly 280 milligrams per liter (table 5). Possible sources of sodium include: ion exchange with clays; dissolution of sodium-bearing minerals; seepage of brines from underlying aquifers; contamination by brines from oil and gas production; or contamination by sewage or animal wastes. Excessive concentrations of sodium can be harmful to plants when used for irrigation. The sodium-adsorption ratio (SAR), as expressed by the following equation:

$$
S A R=\frac{N a^{+}}{\sqrt{\frac{\left(C a^{+2}+M g^{+2}\right)}{2}}}
$$

(concentrations in milliequivalents per liter)

is an index of the likelihood of damage to crops by sodium in water. The two samples with the greatest sodium concentration had a "medium" sodium hazard (SAR between 10 and 18), as defined by U.S. Salinity Laboratory Staff (1954). The other 72 samples had SARs in the low hazard range (SAR less than 10).

Sulfate concentrations ranged from less than 7 to nearly 430 milligrams per liter (table 5, fig. 5). Three samples had a sulfate concentration exceeding the Secondary Maximum Contaminant Level of 250 milligrams. Gypsum in underlying rocks of Permian age may be the primary source of sulfate in the central High Plains aquifer.

Chloride concentrations ranged from 3 to 260 milligrams per liter (table 5, fig. 5). One sample had a chloride concentration exceeding the Secondary Maximum Contaminant Level of 250 milligrams. Possible sources of chloride include: dissolution of chloride-bearing minerals; seepage of brackish waters from underlying aquifers; contamination by brines from oil and gas production; or contamination by sewage or animal wastes. Irrigation water that becomes more saline due to evaporation (Hem, 1989, p. 213-217) also may contribute to elevated chloride and sulfate concentrations.

Fluoride concentration equaled the Maximum Contaminant Level of 4 milligrams per liter in one sample and exceeded the Secondary Maximum Contaminant Level of 2 milligrams per liter in six samples. Fluoride strongly influences bone and tooth formation, but concentrations greater than 0.7 but less than 2 milligrams per liter may lead to mottled discoloration of teeth. Fluoride concentration greater than 4 milligrams per liter will cause discoloration of teeth and can result in pain and tenderness in bones (U.S. Environmental Protection Agency, 2001b). 


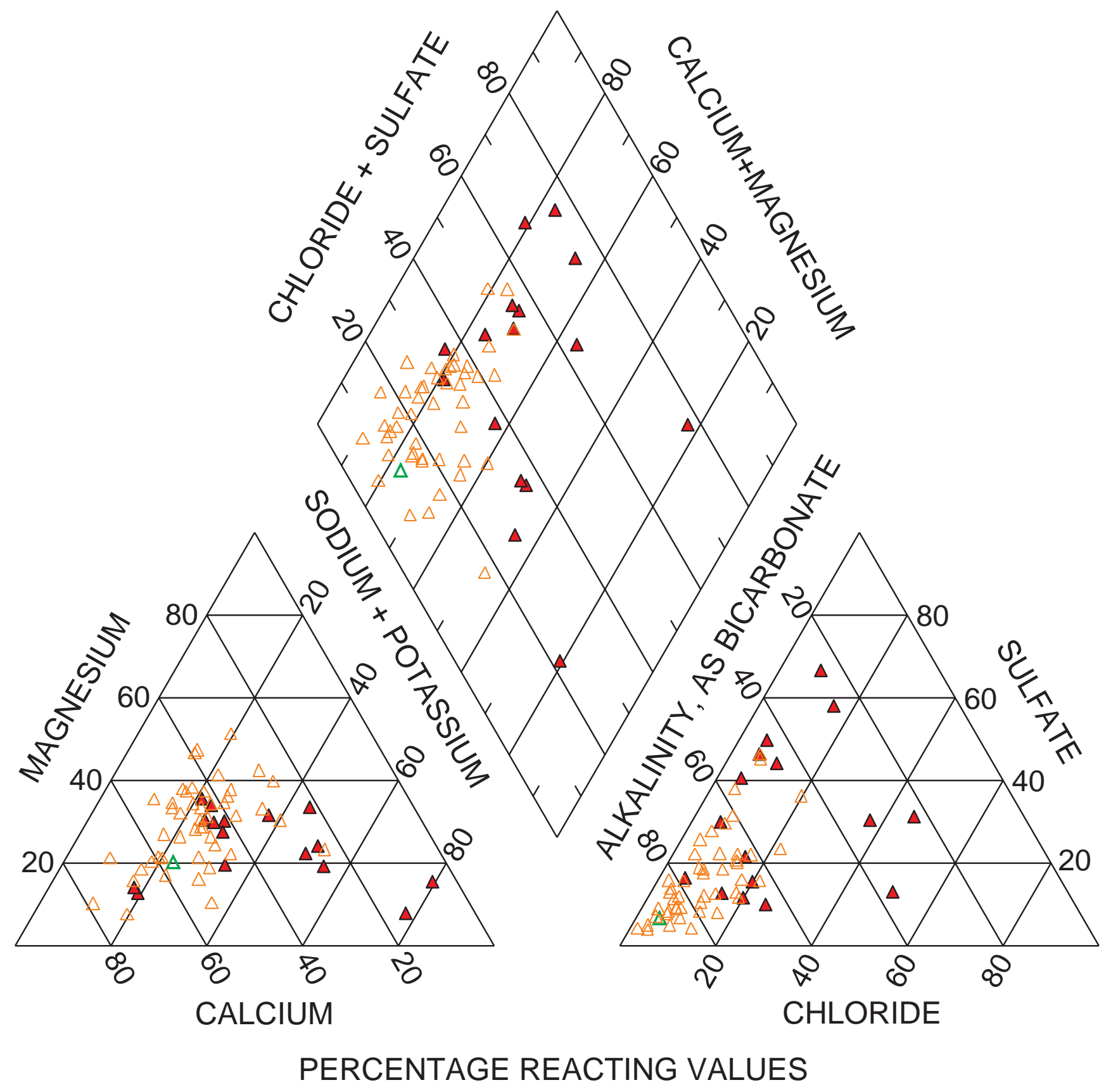

\section{EXPLANATION}

$\triangle$ Dissolved Solids Concentration Less than 250 milligrams per liter

$\triangle$ Dissolved Solids Concentration 250 to 500 milligrams per liter

$\Delta$ Dissolved Solids Concentration Greater than 500 milligrams per liter

Figure 4. Major ion concentrations (expressed as percentages of total milliequivalents per liter) in samples collected in 1999 from 74 domestic water-supply wells completed in the central High Plains aquifer. 


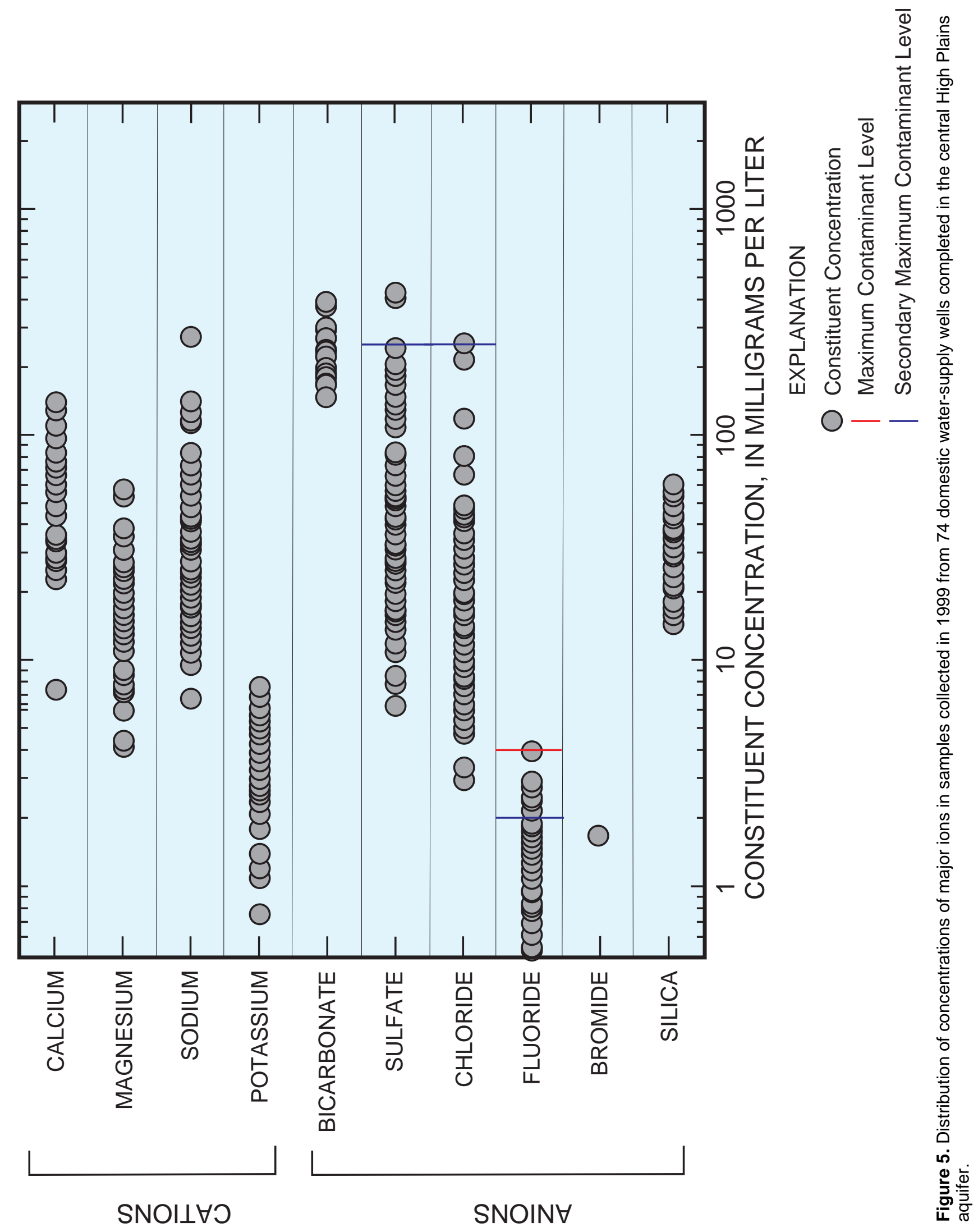


There are no Maximum Contaminant Levels set for potassium, bicarbonate, bromide, and silica and concentrations of those constituents in water from the Central High Plains aquifer were not unusual for ground water.

\section{Nutrients and Dissolved Organic Carbon}

Nutrients are molecules containing the elements nitrogen and phosphorus that are essential for the metabolism of a variety of biota. Nutrient sources include the breakdown of soil organic material, fertilizers, livestock, and sewage. A report reviewing NAWQA nutrient data determined that 2 milligrams per liter of nitrate is an upper limit for natural background concentration (Mueller and Helsel, 1996). Elevated concentrations of nutrients in ground water can indicate that the aquifer is susceptible to contamination. Greater nutrient concentrations can affect the health of humans, livestock, and surface-water habitats.

Dissolved nitrogen in water commonly occurs in two forms, ammonium (referred to as ammonia in this report) and nitrate. Ammonia as nitrogen is the reduced form of nitrogen. Twenty of 74 samples had measured ammonia concentrations equal to or greater than the analytical reporting limit ( 0.02 milligram per liter). The greatest ammonia concentration was 0.04 milligram per liter (table 5). Organic nitrogen plus ammonia as nitrogen concentrations also were small; eight samples exceeded the analytical method reporting limit of 0.1 milligram per liter. The maximum concentration for organic nitrogen was 1.0 milligram per liter. Relatively low concentrations of organic substances and oxygenated conditions indicate that ammonia seeping from the land surface is likely to be nitrified to nitrate.

The USGS National Water Quality Laboratory reports the sum of nitrite plus nitrate. Because nitrite concentration is typically negligible compared to nitrate concentration in ground water, for this report "nitrate" refers to the sum of nitrite plus nitrate as nitrogen. Nitrate concentrations ranged from less than 0.05 to 20 milligrams per liter, with a median of 2.3 milligrams per liter (table 5). The Maximum Contaminant Level for nitrate-nitrogen of 10 milligrams per liter was exceeded in three samples (fig. 6). Forty-five of the 74 samples had nitrate concentrations greater than 2 milligrams per liter, indicating the aquifer is vulnerable to nitrate contamination. Nitrate could remain stable, with little likelihood of reduction to nitrogen gas by denitrification, due to the presence of dissolved oxygen and little to no organic substrate in the aquifer.

Phosphorus readily adsorbs to soils and minerals and dissolved phosphorus concentration in ground water is typically very small. Dissolved phosphorus concentrations ranged from less than 0.004 to 0.054 milligram per liter, with a median concentration of 0.005 milligram per liter. Orthophosphate-phosphorus concentrations ranged from less than 0.01 to 0.052 milligram per liter, with a median concentration of 0.015 milligram per liter (table 5). Orthophosphate concentrations may have been partly an artifact of the sampling process, as it was detected in three of eight field blanks at concentrations ranging from less than 0.01 to 0.021 milligram per liter.

The amount of organic carbon present in ground water can have substantial influence on microbial communities in the aquifer and in turn affect the concentration of redox-sensitive species such as dissolved oxygen, nutrients, and metals. Dissolved organic carbon was measured in relatively small concentrations, ranging from 0.2 to 2.0 milligrams per liter, with a median concentration of 0.5 milligram per liter. Dissolved oxygen is the first redox sensitive constituent to be depleted during microbial consumption of organic carbon. The sample having the greatest concentration of dissolved organic carbon, 2.0 milligrams per liter, had a dissolved oxygen concentration of 7.2 milligrams per liter (Appendix 1), indicating that there is not sufficient dissolved organic carbon in the central High Plains aquifer for nitrate to be reduced by denitrification. Dissolved organic carbon also was detected in most blank samples, in similar or greater concentrations than in the environmental samples, indicating that actual environmental concentrations may have been less than the reported values.

\section{Trace Elements}

Trace elements are generally defined as elements occurring in natural water at concentrations less than 1 milligram per liter (Drever, 1988). Most of the trace elements analyzed (table 4) are metals or semi-metallic elements, which occur naturally from the weathering of minerals. Some trace elements such as aluminum, chromium, copper, iron, lead, nickel, 


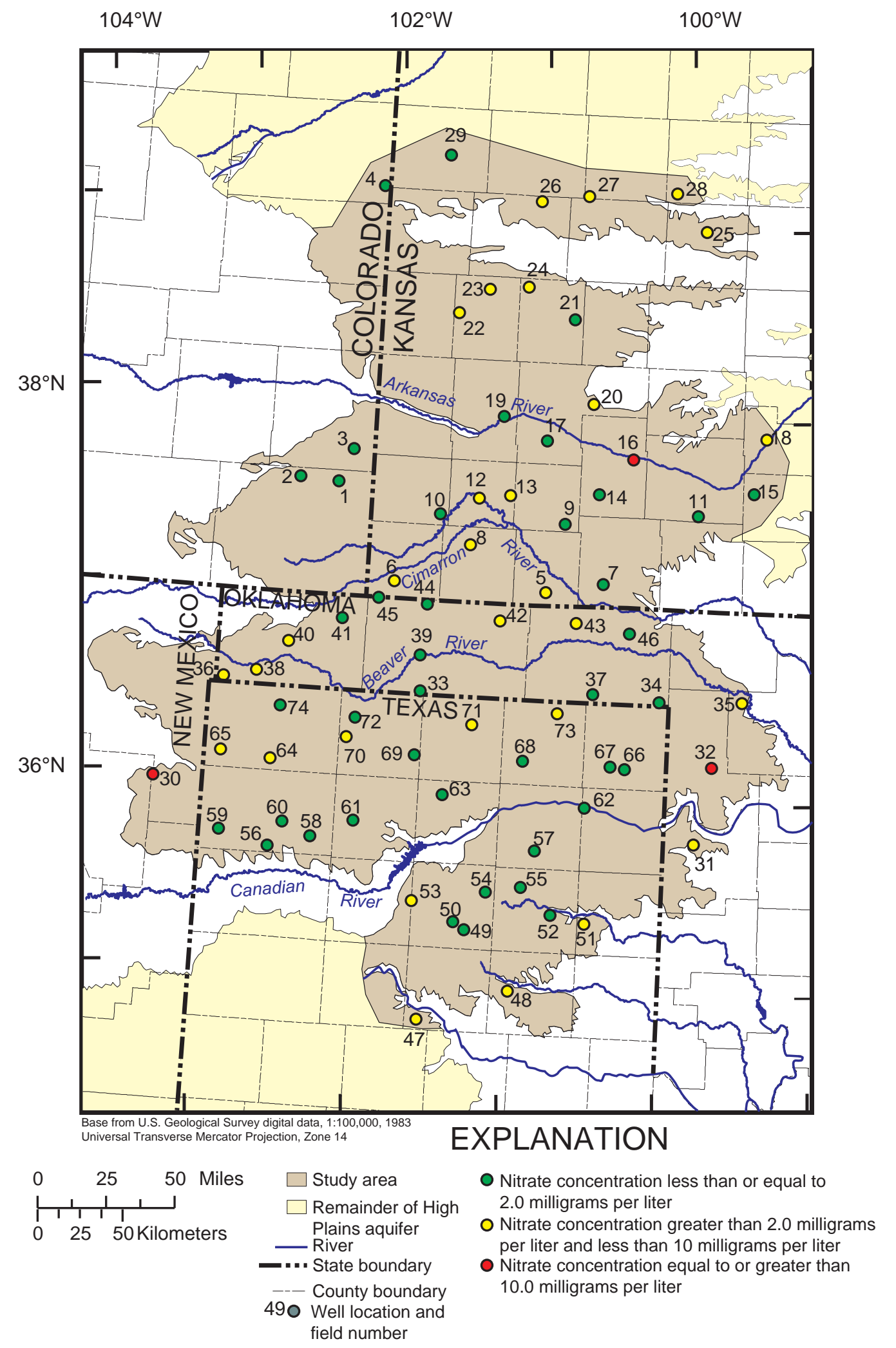

Figure 6. Distribution of nitrate as nitrogen concentration in samples collected in 1999 form 74 domestic water-supply wells completed in the central High Plains aquifer. 
and zinc also can be derived from plumbing and well construction materials. Antimony, beryllium, cadmium, cobalt, and silver were not detected in any of the samples (fig. 7).

Aluminum may be derived from the dissolution of clay minerals. Aluminum was detected in 48 (fig. 7) of the samples, with a median concentration of 3.0 micrograms per liter (table 5). Blank samples contained a median aluminum concentration of 4.3 micrograms per liter. The source of aluminum in blank samples is unknown, but similar concentrations in blank and environmental samples qualifies the detection of aluminum in the environmental samples.

Arsenic was detected in 63 of the 74 samples, with a median concentration of 2 micrograms per liter. None of the samples had arsenic exceeding the proposed Maximum Contaminant Level of 10 micrograms per liter (fig. 7, U.S. Environmental Protection Agency, 2001a). Arsenic may be derived from natural trace minerals in the High Plains aquifer or underlying bedrock units. Prior to the advent of modern organic pesticides, arsenic compounds commonly were used as pesticides in agricultural areas (Reigart and Roberts, 1998, chapter 14).

Barium was detected in all 74 samples (fig. 7), but at concentrations substantially less than the Maximum Contaminant Level of 2,000 micrograms per liter (U.S. Environmental Protection Agency, 2001a). Barium is probably related to dissolution of the naturally-occurring mineral barite.

Chromium and copper were both detected in substantial numbers of samples (fig. 7, Appendix 1), but detected concentrations were much less than Maximum Contaminant Levels (U.S. Environmental Protection Agency, 2001a). Both of these metals may be derived from dissolution of naturally-occurring metallic minerals or may leach from well casings and other components of plumbing systems.

Lead also may be derived from solder used in plumbing systems and from natural sources. Three water samples contained low concentrations of lead, which exceeded the Maximum Contaminant Level (non-detect), but none of the samples had lead concentrations sufficiently high to exceed the Treatment Technique Level (15 micrograms per liter), at which public water suppliers are required to treat water to remove lead (U.S. Environmental Protection Agency, 2001a).

Only six samples had detectable concentrations of iron, and four samples had detectable concentra- tions of manganese. Secondary Maximum Contaminant Levels are set for iron and manganese due to staining of laundry and porcelain caused by those metals. No iron concentrations exceeded the Secondary Maximum Contaminant Level of 300 micrograms per liter (table 5, fig. 7, U.S. Environmental Protection Agency, 2001a). Manganese concentration exceeded the Secondary Maximum Contaminant Level of 50 micrograms per liter in one sample. That particular sample had a dissolved oxygen concentration of 6 milligrams per liter, so the relatively high detected manganese concentration may have been due to colloidal material in the aquifer or in the plumbing system of that well. Manganese is naturally-occurring and its solubility in water is governed by oxidation conditions. Manganese and iron typically occur in greater concentrations in reducing conditions, as the presence of oxygen facilitates formation of lowsolubility oxide and hydroxide compounds. Exposure to elevated concentrations of manganese, particularly airborne manganese, has been tentatively associated with central-nervous system disorders such as learning disabilities (Collipp and others, 1983; Cotzias and others, 1968; Cotzias, 1974)) and muscle control (Gorrell and others; 1996), and susceptibility to infection (World Health Organization, 2001).

Molybdenum was detected in 67 samples. Molybdenum is associated with dissolution of molybdenite and is highly soluble under oxidizing conditions. It is an essential element in animal and plant nutrition (Hem, 1989, p. 40) and has no Maximum Contaminant Level (U.S. Environmental Protection Agency, 2001a).

Selenium, a semi-metallic element, was detected in 64 samples at concentrations ranging up to 18 micrograms per liter (fig. 7, table 5). Like molybdenum, selenium is a nutrient for plants and animals, but it may have toxic effects in small doses, leading to establishment of a Maximum Contaminant Level of 50 micrograms per liter. Selenium may be associated with ferric oxyhydroxides associated with uranium ore deposits in sandstones of the Western United States (Hem, 1989, p. 145).

Zinc was detected in 70 samples at concentrations as great as 170 micrograms per liter. Zinc occurs in crustal rocks in similar abundance as copper and nickel, but is substantially more soluble in natural waters than those metals. Zinc also is a component of brass and bronze and is used to galvanize steel pipes and sheets. Galvanized metals associated with 


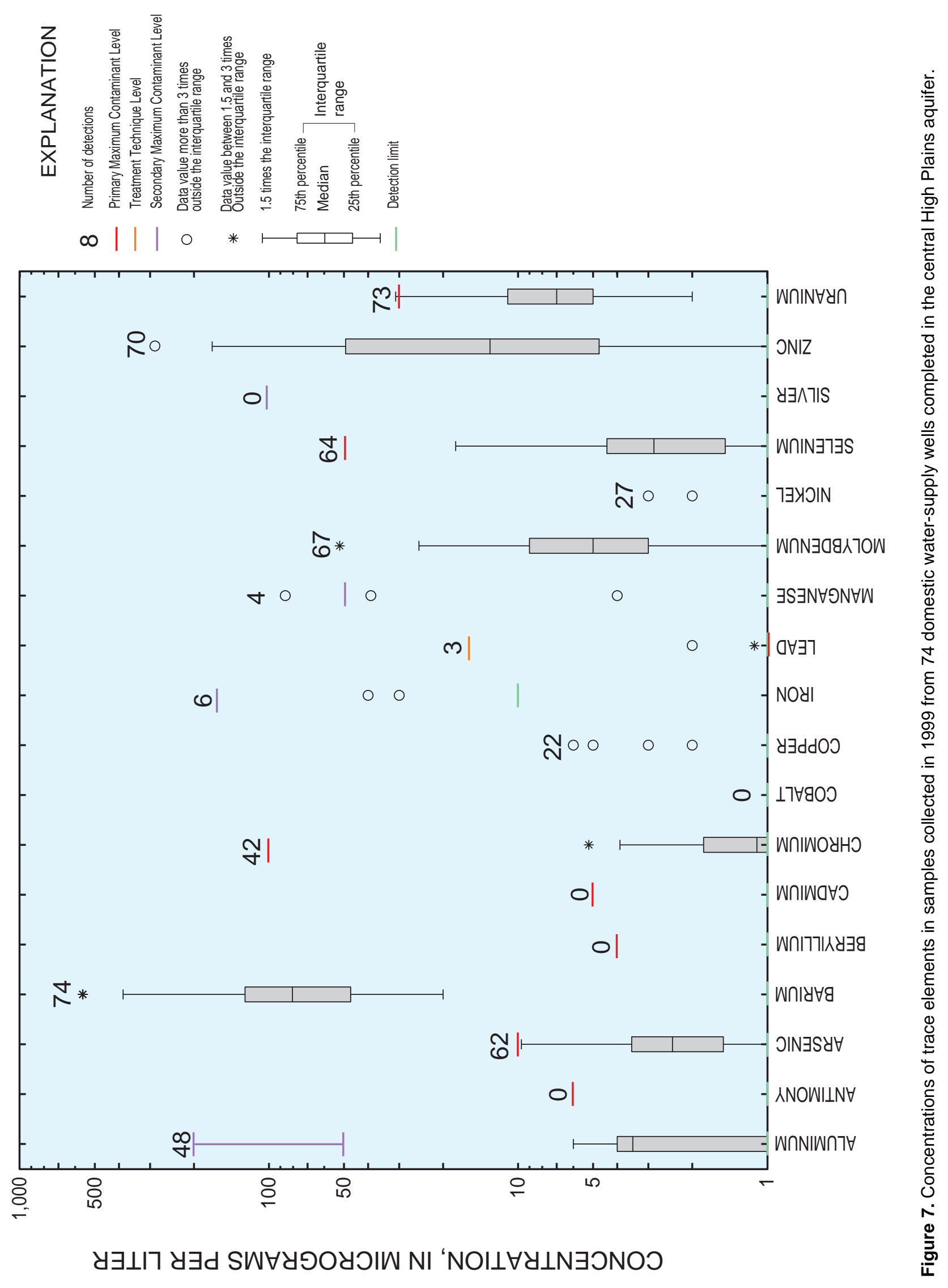


Table 6. Frequencies of ranges of radon concentration compared to underlying bedrock units for samples collected in 1999 from 74 domestic water-supply wells completed in the central High Plains aquifer

[percentages of group in parentheses]

\begin{tabular}{|c|c|c|c|}
\hline $\begin{array}{l}\text { Underlying bedrock } \\
\text { group }\end{array}$ & $\begin{array}{c}\text { Number of wells } \\
\text { producing water } \\
\text { with radon concen- } \\
\text { tration less than } \\
300 \text { picocuries per } \\
\text { liter }\end{array}$ & $\begin{array}{l}\text { Number of wells } \\
\text { producing water } \\
\text { with radon concen- } \\
\text { tration equal to or } \\
\text { greater than } 300 \\
\text { picocuries per liter }\end{array}$ & $\begin{array}{l}\text { Total number of } \\
\text { wells }\end{array}$ \\
\hline $\begin{array}{l}\text { Upper Cretaceous Period } \\
\text { shales, chalks, lime- } \\
\text { stones, and sandstones }\end{array}$ & $2(14)$ & $12(86)$ & $14(100)$ \\
\hline $\begin{array}{c}\text { Lower Cretaceous Period } \\
\text { sandstones and shales }\end{array}$ & $1(8)$ & $12(92)$ & $13(100)$ \\
\hline $\begin{array}{l}\text { Jurassic and Triassic } \\
\text { Period sandstones and } \\
\text { shales }\end{array}$ & $3(19)$ & $13(81)$ & $16(100)$ \\
\hline $\begin{array}{l}\text { Permian Period oxidized } \\
\text { sandstones and evapor- } \\
\text { ites, with minor shales }\end{array}$ & $13(42)$ & $18(58)$ & $31(100)$ \\
\hline Total Number of Wells & $19(26)$ & $55(74)$ & $74(100)$ \\
\hline
\end{tabular}

plumbing or well casing may augment concentrations of zinc in water from wells constructed of such materials.

Uranium was detected in 73 water samples (fig. 7). Uranium concentration exceeded the proposed Maximum Contaminant Level of 30 micrograms per liter (U.S. Environmental Protection Agency, 2001a) in one sample. Unlike manganese and iron, uranium tends to be more soluble under oxidizing conditions (Hem, 1985, p. 148). Exposure to uranium in drinking water may affect the kidneys and prolonged exposure at concentrations exceeding the Maximum Contaminant level may increase the risk of cancer (U.S. Environmental Protection Agency, 2001b).

\section{Radon}

Radon-222 is a product of the radioactive decay of the radium-226 isotope that occurs in most aquifers containing uranium (Hem, 1989, p. 149). Radon is a water-soluble gas that is highly volatile and is shortlived, with a half-life of 3.8 days. Most of the hazard associated with radon is associated with inhalation of the gas as it volatilizes from water used in showers, washing machines, and other appliances. Lubin and
Boice (1997) reported that radon concentrations in air of 4 picocuries per liter may increase lung cancer risks by about 14 percent over a 30 -year period. There is a proposed Maximum Contaminant Level ranging from 300 to 4,000 picocuries per liter for radon, dependent on whether a state or utility has developed mitigation programs for indoor airborne radon (U.S. Environmental Protection Agency, 1999). Radon concentrations greater than 300 picocuries per liter are common in ground water samples from the central High Plains aquifer. Fifty-five of the samples had radon concentrations exceeding the proposed Maximum Contaminant Level of 300 picocuries per liter. Water, and dissolved substances and gases such as radon may seep up into the High Plains aquifer from underlying units (Gutentag and others, 1984, p. 15) and the concentration of radon in ground water may be related to the amount of radioactive minerals in the geologic units directly underlying the central High Plains aquifer. Samples from areas underlain by sandstones, shales and limestones of Triassic, Jurassic, or Cretaceous age (fig. 8, table 6) tend to have greater concentrations of radon. Uranium, a source of radon gas, is associated with sandstones in the western United States (Hem, 1985). Reducing conditions associated with organic 


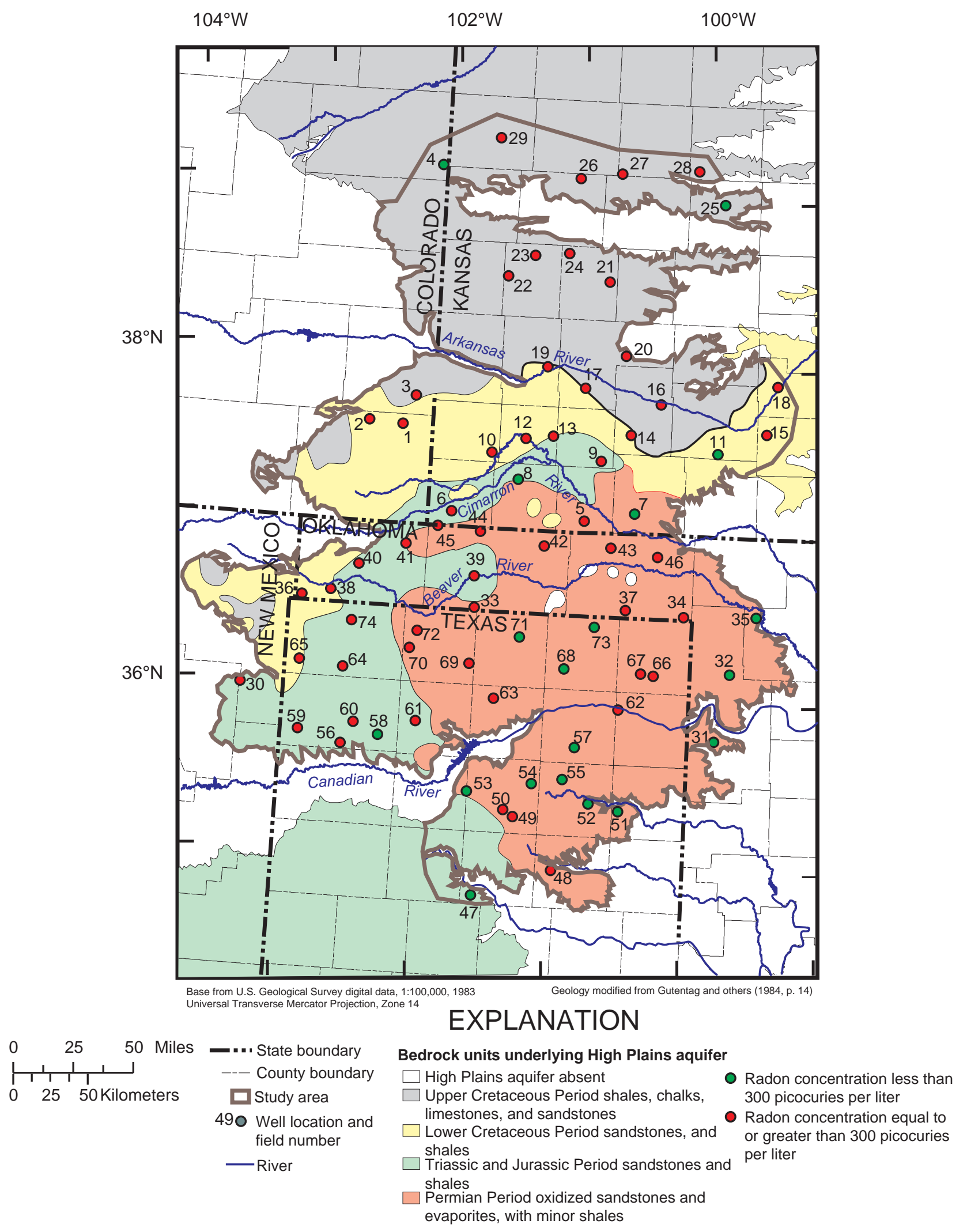

Figure 8. Radon concentration in samples collected in 1999 from 74 domestic water-supply wells completed in the central High Plains aquifer. 
matter in shales in those units also may be conducive to precipitation and concentration of uranium. Radon concentrations exceeded 300 picocuries per liter in 89 percent of ground-water samples from areas where rocks of Cretaceous age directly underlie the central High Plains aquifer. In areas where the aquifer is directly underlain by rocks of Triassic and Jurassic age, 81 percent of ground-water samples had radon concentrations exceeding 300 picocuries per liter. Radon in 58 percent of the samples exceeded that concentration in areas where Permian age rocks directly underlie the aquifer. The Permian-age units are typically well-oxidized sandstones and shales known as "red beds." The oxidizing conditions in which those units were deposited may have minimized precipitation and concentration of uranium.

\section{Volatile Organic Compounds}

Volatile organic compounds are relatively low molecular-weight hydrocarbons that volatilize at low temperatures, and have great aqueous solubility, mobility, and resistance to degradation. Some volatile organic compounds have been judged to be carcinogenic. Some volatile organic compounds are produced naturally from the decomposition of organic matter and are emitted from living vegetation (Pepper and others, 1996). However, use of or production of volatile organic compounds in industrial, manufacturing, and agricultural activities pose the greatest potential for volatile organic compound contamination of ground-water. In agricultural areas, land application of some pesticides in crop production and the use of fumigants during grain storage are potential sources of volatile organic compounds (U.S. Environmental Protection Agency, 2001b). In parts of the central High Plains, lighter fractions of petroleum, such as benzene, toluene, ethylbenzene, and xylenes ("BTEX" compounds) may be introduced to the aquifer by spills and leaks in the vicinity of petroleum production wells and related facilities.

Nine wells produced water with detectable concentrations of one or more volatile organic compounds (figs. 9 and 10). All detected concentrations of volatile organic compounds were substantially less than Maximum Contaminant Levels (fig. 9). Toluene was the most commonly detected volatile organic compound, being detected in eight samples (wells 21, 31, 37, 43, 53, 62, 68, 73), ranging in concentration from 0.05 to 0.16 microgram per liter. Toluene was detected in quality-control samples in similar concentrations, indicating contamination in the sampling or analytical processes, lessening the likelihood that toluene was present in the central High Plains aquifer.

The sample from well number $74 \mathrm{did}$ not contain toluene, but did contain detectable concentrations of chloroform, tetrachloroethene, $o$-dichlorobenzene, and $p$-dichlorobenzene. Chloroform is used in manufacturing of refrigerants and propellants, fumigants, and solvents and is a by-product of chlorination of natural organic compounds in water (Vershueren, 1983). Chloroform also was detected in one of six field blank samples. Tetrachloroethene commonly is used as a degreaser and for dry cleaning. Sources of odichlorobenzene and p-dichlorobenzene include: solvents, metal polishes, soil fumigants, and insecticides (Vershueren, 1983).

\section{Pesticides}

Pesticides are compounds generally used to control or kill undesirable vegetation and insects. The primary uses of pesticides in the study area are on cropland to enhance crop production or around homes and livestock to control pests. Widespread use of pesticides creates the potential for movement of pesticides or pesticide breakdown products into ground water. The presence of pesticides in ground water is a human-health concern for those using ground water as a drinking-water supply. Human health problems ranging from liver and kidney damage to cancer and reproductive failure are some of the effects of chronic exposure to pesticides (U.S. Environmental Protection Agency, 2001b).

Forty-seven pesticides and six pesticide metabolites (breakdown products) were analyzed (table 4), including the following pesticide classes: triazines, chloroacetanilides, organophosphorus, carbamates, and organochlorines. One or more pesticides were detected in 18 water samples ( 24 percent). Thirteen different pesticides were detected (fig. 11). All of the detected pesticides that have Maximum Contaminant Levels were measured at concentrations substantially less than those levels.

The most frequently detected pesticides were deethylatrazine (a metabolite of atrazine) and atrazine 


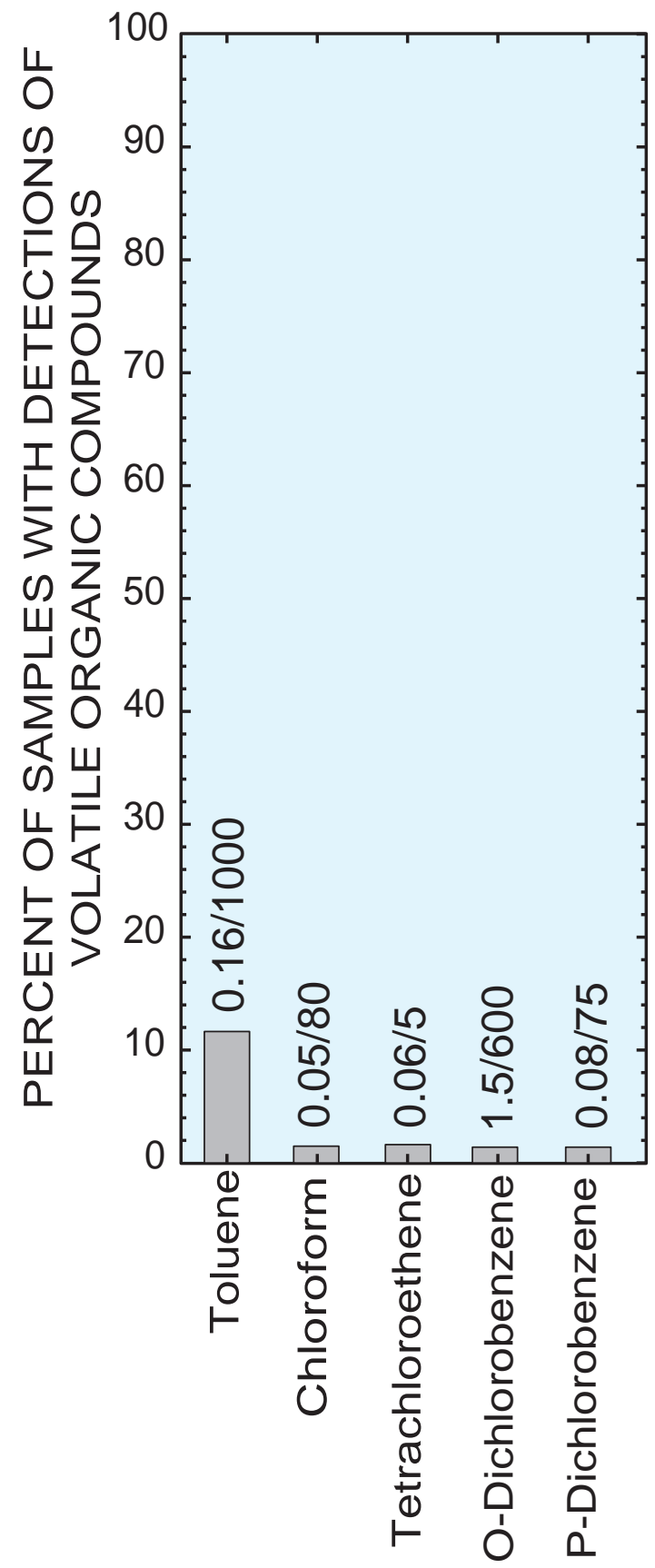

\section{VOLATILE ORGANIC COMPOUND}

\section{EXPLANATION}

0.16/1000 - Maximum detected concentration, in micrograms per liter/ Maximum Contaminant Limit, in micrograms per liter

Figure 9. Frequencies of detection of volatile organic compounds in samples collected in 1999 from 74 domestic water-supply wells completed in the central High Plains aquifer. 


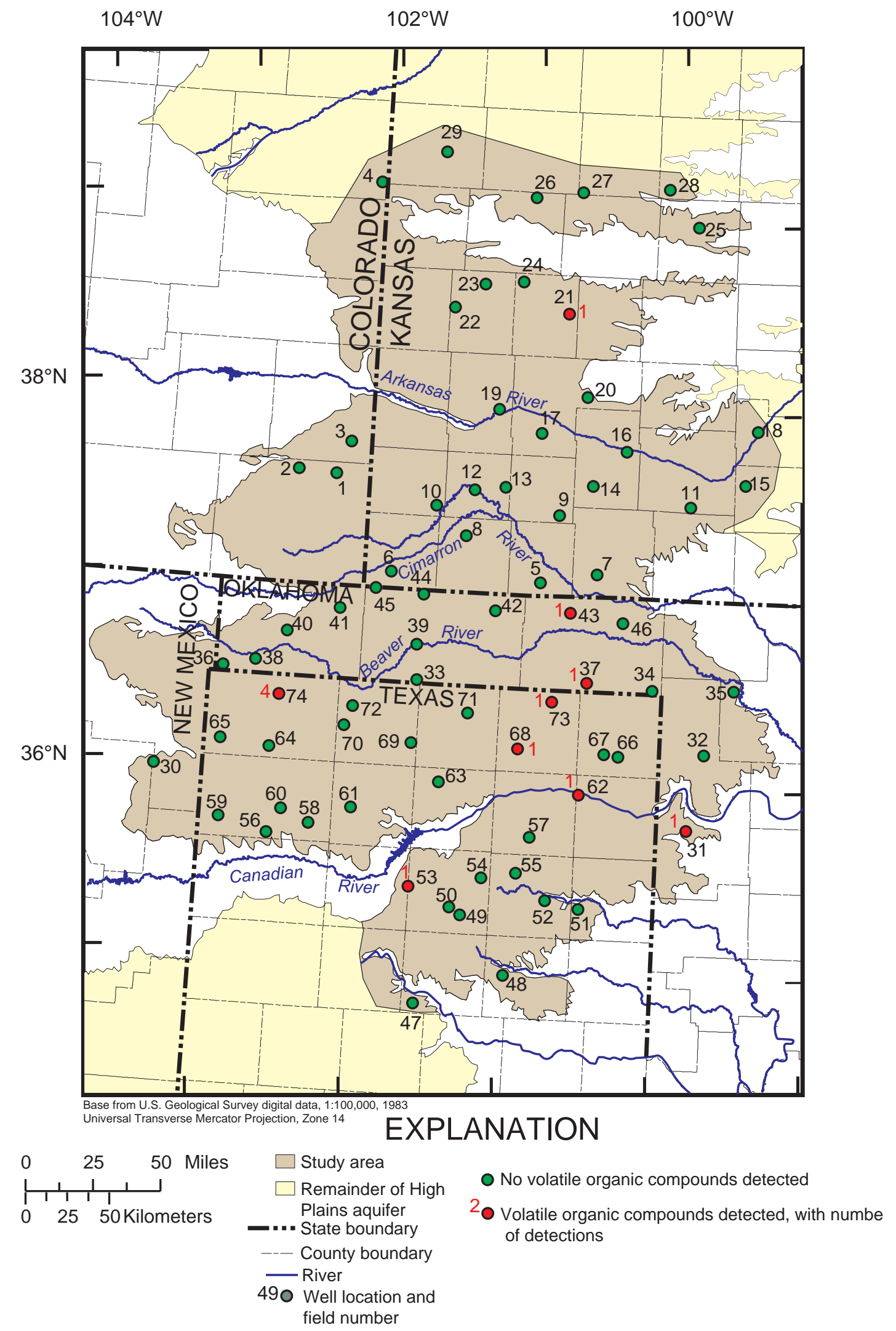

Figure 10. Distribution of volatile organic compound detections in samples collected in 1999 from 74 domestic water-supply wells completed in the central High Plains aquifer. 


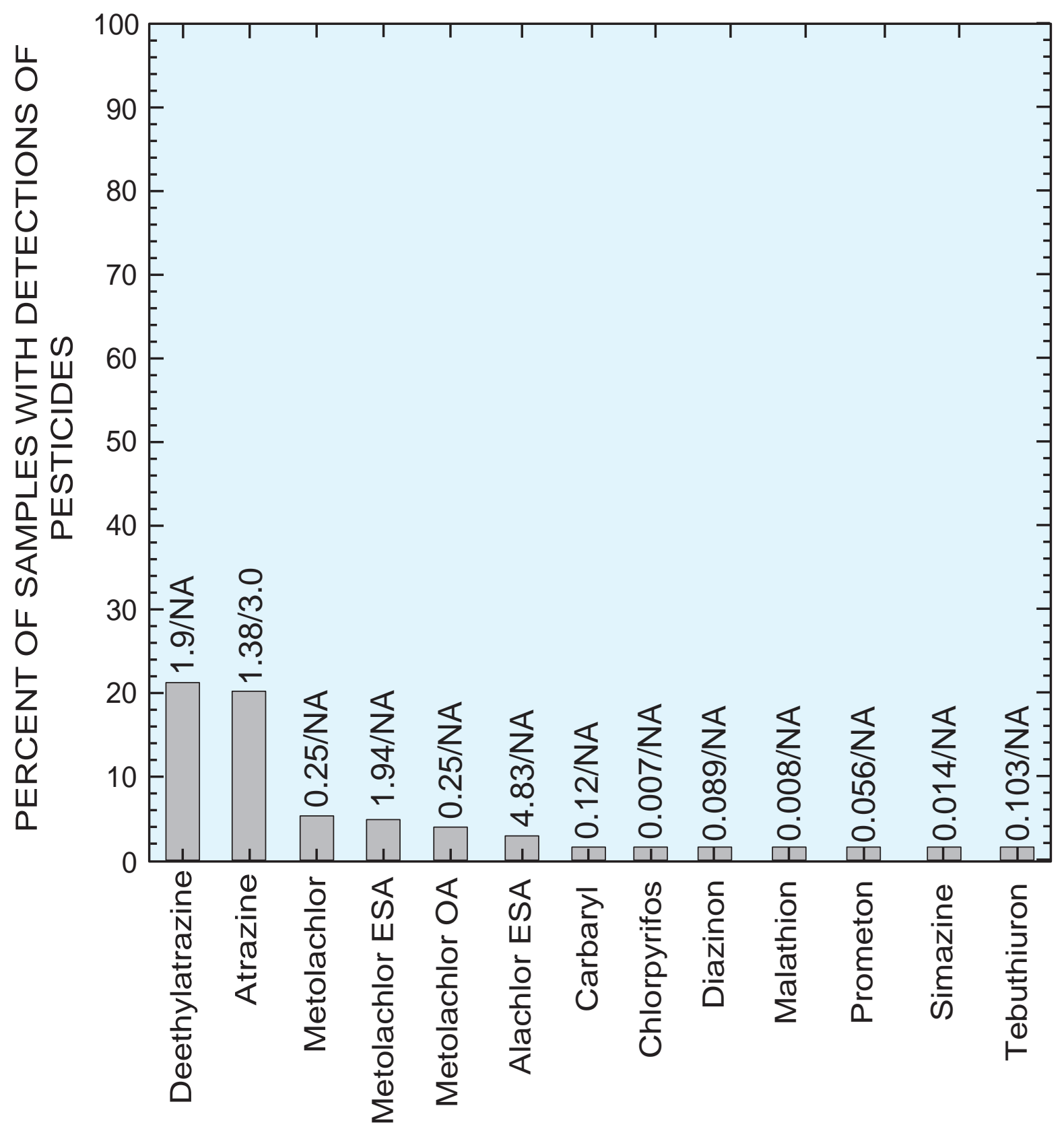

PESTICIDE OR PESTICIDE METABOLITE EXPLANATION

0.01/100 - Maximum detected concentration, in micrograms per liter/ Maximum Contaminant Limit, in micrograms per liter

NA - No existing Maximum Contaminant Limit

Figure 11. Frequencies of detection of pesticides in samples collected in 1999 from 74 domestic water-supply wells completed in the central High Plains aquifer. 
Table 7. Occurrence of detectable concentration of pesticides in samples collected in 1999 from 74 domestic water-supply wells completed in the central High Plains aquifer

[percentage of group in parentheses]

\begin{tabular}{cc}
\hline $\begin{array}{c}\text { Number of pesticides } \\
\text { detected in water sample } \\
\text { from each well }\end{array}$ & Number of wells \\
\hline 0 & $56(76)$ \\
1 & $3(4)$ \\
2 & $9(12)$ \\
3 & $2(3)$ \\
4 & $1(1)$ \\
5 & $1(1)$ \\
6 & $2(3)$ \\
\hline Total & $74(100)$ \\
\hline
\end{tabular}

(fig. 11). Deethylatrazine was detected in 17 samples (wells 1, 4, 9, 13, 15, 16, 18, 22, 23, 24, 25, 26, 27, 29, $37,51,71)$ and atrazine was detected in 15 water samples (wells 9, 13, 15, 16, 18, 22, 23, 24, 25, 26, 29, $37,51,61$, and 71) (fig. 12). In 14 of 15 of the samples with detectable atrazine, deethylatrazine also was detected.

The next most commonly detected pesticides were metolachlor, detected in water from four wells $(16,26,29$, and 61), and its breakdown products metolachlor ethane sulfonic acid (ESA) (wells 16, 18, 25, 26) and metolachlor oxanilic acid (OA) (wells 16 and 26) (figs. 11 and 12).

A metabolite of alachlor, alachlor ESA, was detected in a sample from well 16 (figs. 11and 12). The remainder of detected herbicides-chlorpyrifos (used in Dursban and Lorsban), diazinon, malathion, prometon, simazine, and tebuthiuron-were detected in small concentrations in the sample from well 61 (figs. 11 and 12).

Additional detected pesticides included simazine, alachlor ESA (a breakdown product of alachlor), carbaryl, chlorpyrifos, diazinon, malathion, prometon, pendimethalin, and tebuthiuron. Three of the insecticides, carbaryl, chlorpyrifos, and diazinon, were all detected in the sample from well number 61 .

Although pesticide detections were scattered from the southernmost to the northernmost sampled well, 11 of the 18 wells with pesticide detections were in the Kansas portion of the study area (fig. 12). Variability of detections of pesticides is probably due to factors such as land use in the area contributing water to the well, ground-water flow velocities, soil characteristics such as permeability and organic carbon content, permeabilities of geologic materials, and well construction. Most of the detected pesticides are restricted-use pesticides typically associated with cropland. In 14 of 18 samples with one or more detectable pesticides, the depth to water in the sampled wells was less than 200 feet below the land surface (table 2, Appendix 1). However, pesticides were detected in three samples from wells having depths to water greater than 300 feet.

Of the 18 wells with detectable pesticides, it was most common to have two compounds detected (table 7). Six of the samples had more than two detectable pesticides (fig. 12). Two wells (numbers 16 and 61) produced water with six detectable pesticides (fig. 12). 

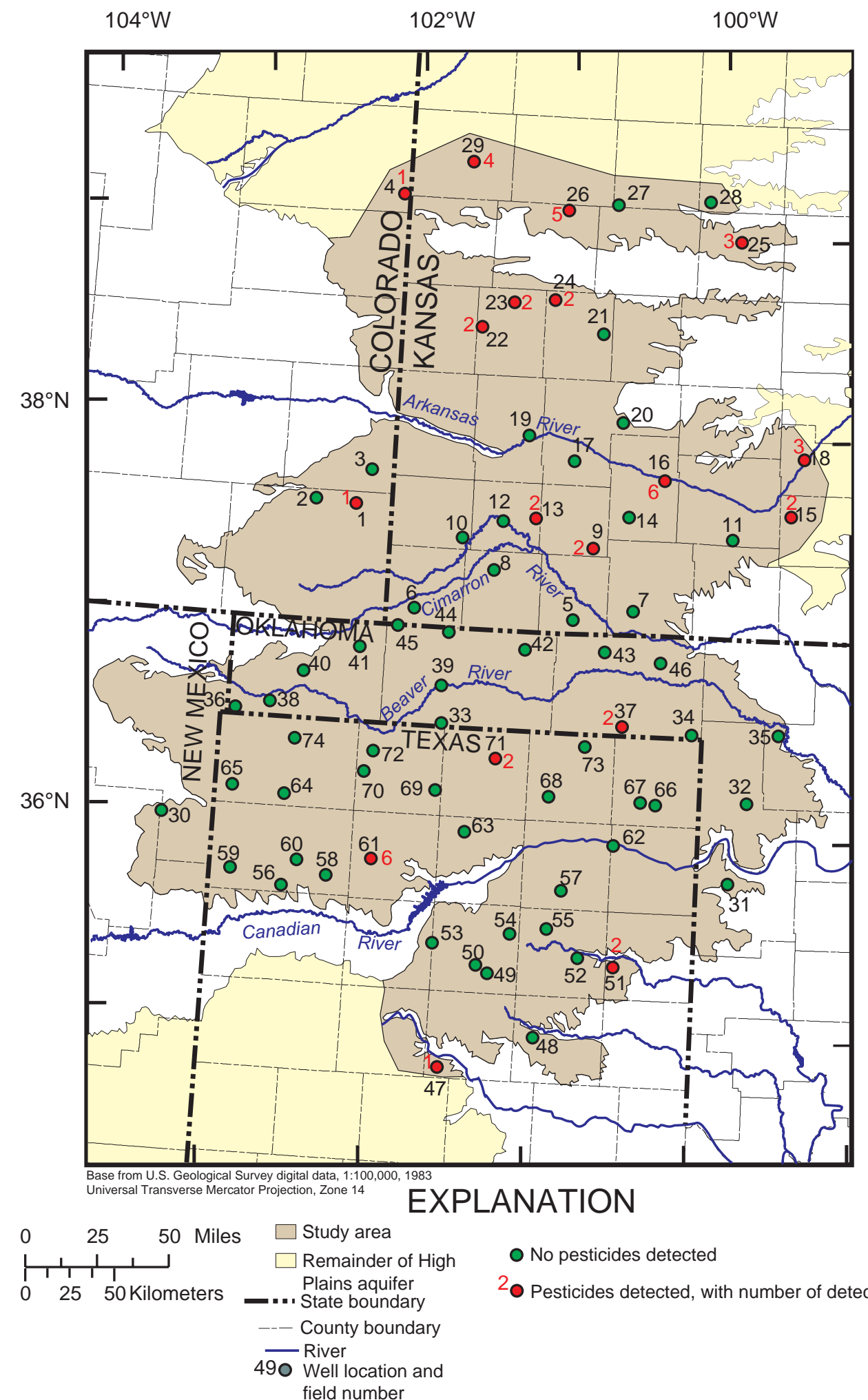

No pesticides detected

${ }^{2}$ o Pesticides detected, with number of detections

Figure 12. Distribution of pesticide detections in samples collected in 1999 from 74 domestic water-supply wells completed in the central High Plains aquifer. 


\section{Tritium}

Tritium is a naturally occurring radioactive isotope of hydrogen that is present in some water molecules. Prior to the atmospheric testing of nuclear weapons, the tritium concentration in precipitation was approximately 8 tritium units (Thatcher, 1962). Nuclear testing introduced large concentrations of tritium into the atmosphere, peaking to concentrations of up to 8,000 tritium units in 1963 (Hem, 1989, p. 150). The large flux of tritium into the atmosphere during a relatively short period and the constant rate of decay with time makes tritium a useful tool for determining recharge ages of ground water. Due to the rapid rate of radioactive decay of tritium (half life of 12.4 years), the minimum concentration of tritium in ground water indicating "post-bomb" recharge (since 1953 ) is about 0.5 tritium unit (McMahon, 2000). The tritium analysis used for this study has a reporting level of 0.32 tritium unit, or 1.0 picocurie per liter.

A subset of 51 of the ground-water samples were analyzed for tritium. The tested sites had nitrate concentrations less than 4.0 milligrams per liter. Twenty-two water samples containing nitrate concentrations greater than 4.0 milligrams per liter were assumed to be composed of recent, or "post-bomb" recharge, so were not analyzed for tritium concentration. Ten of 51 analyzed samples had tritium concentration greater than 0.5 tritium unit and are distributed throughout the study area (fig.13). Wells with screens set deeper below the land surface are less likely to be recharged recently. The tops of the screens of the 42 wells with tritium concentration less than or equal to 0.5 tritium unit (indicating pre-1953 recharge) had a median depth of 260 feet below land surface, whereas the tops of the screens of the 22 wells with elevated nitrate concentration (indicating recent recharge) had a median depth of 147 feet below land surface, and the tops of the screens of the 10 wells producing tritium greater than 0.5 tritium unit (also indicating recent recharge) had a median depth of 152 feet below land surface (fig. 14). Mann-Whitney statistical tests (Mann, 1945) indicated that the depths of the tops of well screens were significantly (p-values of tests less than 0.05) deeper for samples with tritium concentrations indicating pre-1953 recharge, whereas the wells producing samples with nitrate concentration greater than 4.0 milligrams per liter and tritium concentration indicating post-1953 recharge had similar depths of well screen tops (fig. 14). In general, wells with screens deeper than 250 feet below land surface were less likely to have indications of recent recharge.

Because nitrate or tritium concentration and depths of the tops of well screens may be related to dates of recharge, and to vulnerability to contamination by manmade materials used at the land surface, there may be an association between nitrate and tritium and manmade organic compounds, which may be used, applied, or spilled at the land surface. However, six of the nine wells that produced water with detectable volatile organic compounds did not have detectable tritium, indicating that they were not recently recharged (table 8). Five of the eight samples with detectable toluene and the sample with the other four detected volatile organic compounds (well number 74) did not have detectable tritium. Some of the detected volatile organic compounds may be artifacts of the sampling process or simply may have seeped to ground water prior to 1953 . Toluene and chloroform may be naturally occurring, particularly near organic deposits such as peats or petroleum. Fourteen of the 18 wells producing water with detectable pesticide concentrations also had elevated nitrate or tritium concentration (table 8). The majority of the samples not containing detectable pesticides (39 of 56) also did not have tritium concentration greater than 0.5 tritium unit (table 8), which also indicates that recently recharged ground water is the probable source of pesticides in the ground-water samples.

\section{SUMMARY}

The central High Plains aquifer, which consists of interbedded caliche, clay, sand, and gravel, extends over 38,000 square miles of southeastern Colorado, southwestern Kansas, northeastern New Mexico, northwestern Oklahoma, and northwestern Texas. The area overlying the central High Plains aquifer is sparsely populated, with agriculture being the primary activity. Wheat is the primary crop in the study area, followed by corn and sorghum. Irrigation of grain crops accounted for 95 percent of the water use in 1995 from the central High Plains aquifer. This report describes water-quality data collected between April and August 1999 from 74 domestic-supply wells completed in the central High Plains aquifer for a broad-scale assessment of water-quality over the central High Plains study area. 


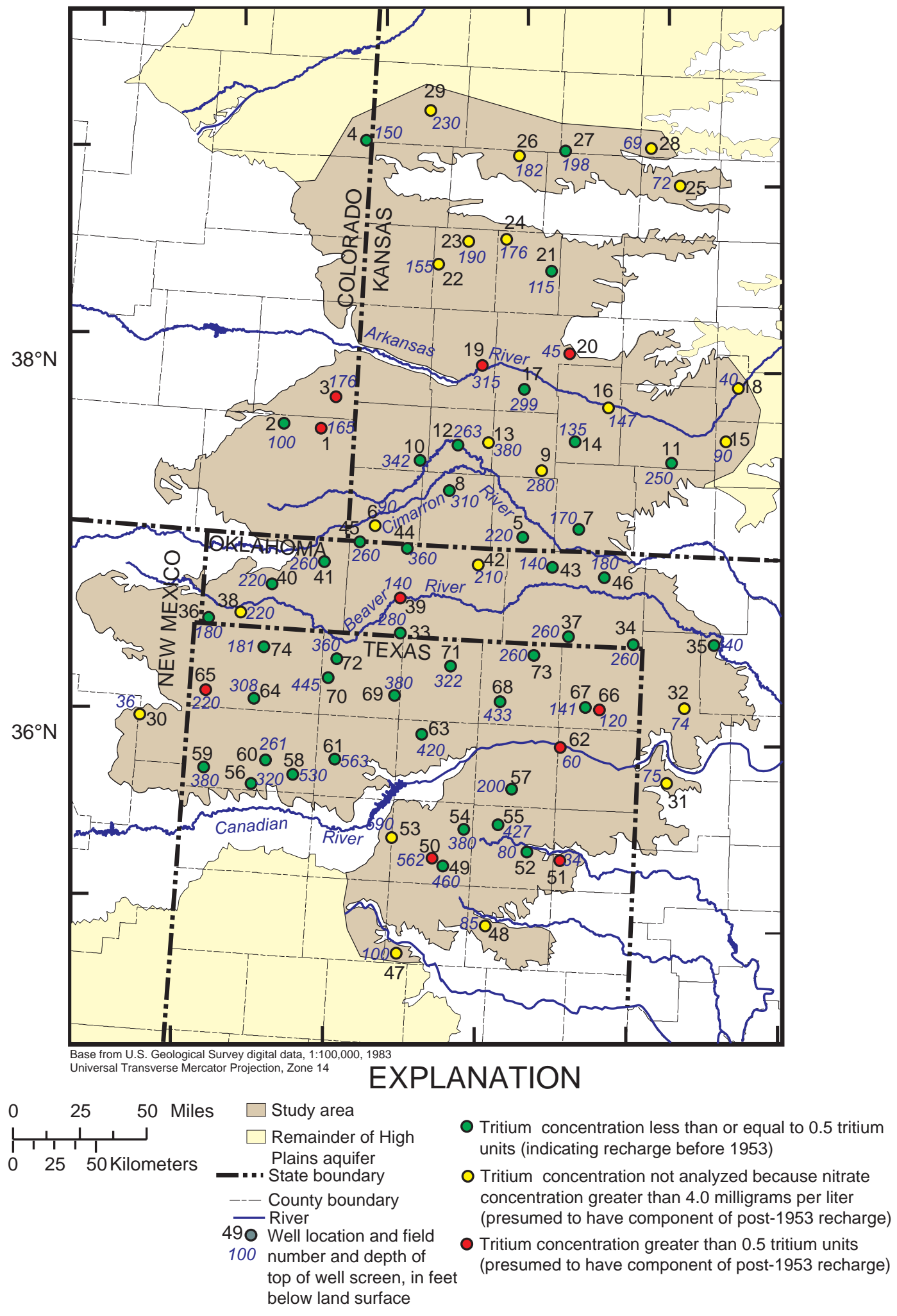

Figure 13. Distribution of tritium concentration in samples collected in 1999 from 74 domestic watersupply wells completed in the central High Plains aquifer. 


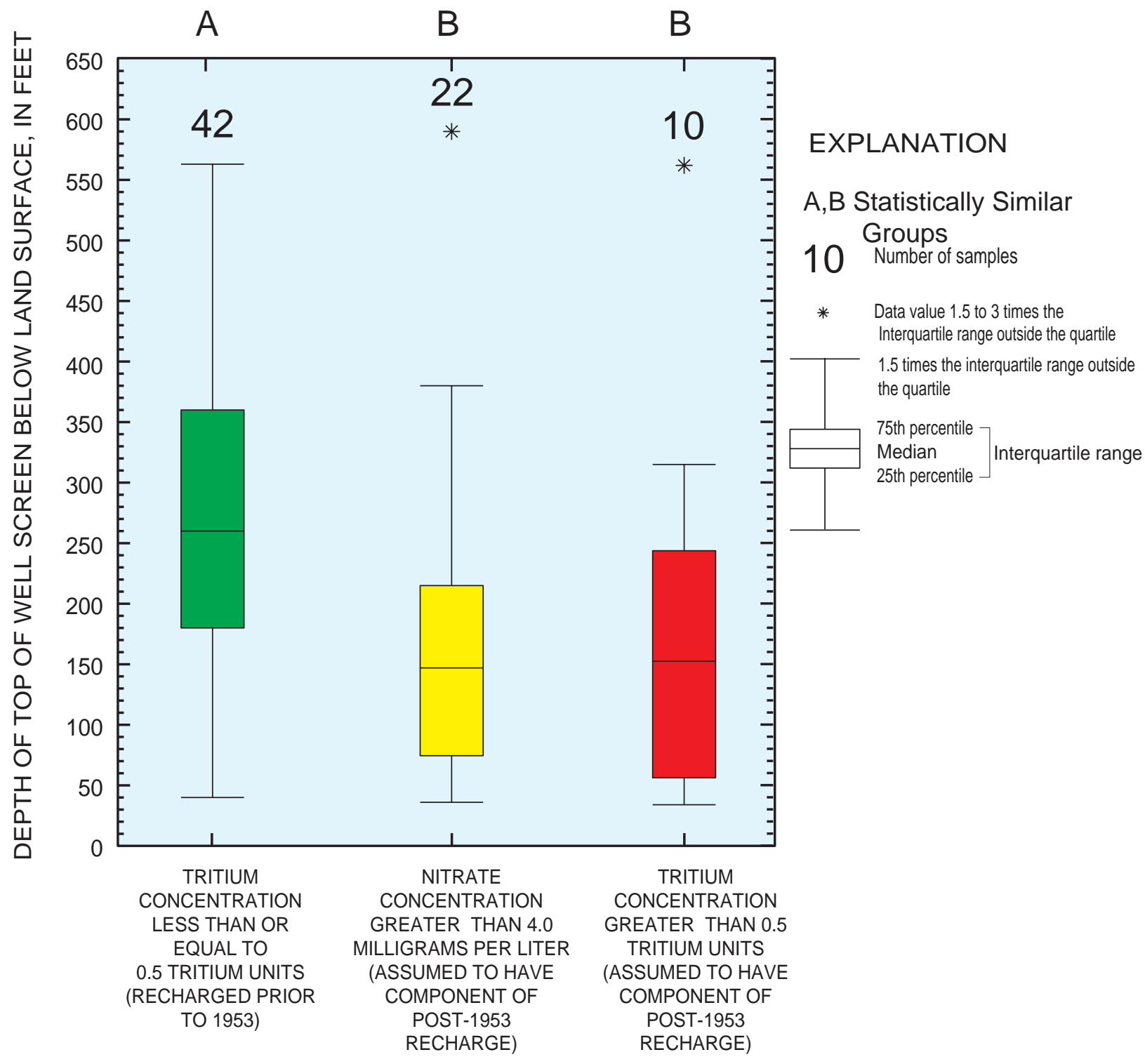

Figure 14. Depths to tops of well screens, grouped by likely pre-1953 and post-1953 recharge age dates for 74 domestic water-supply wells completed in the central High Plains aquifer. 
Table 8. Frequencies of detection of volatile organic compounds and pesticides compared to ranges of nitrate-nitrogen and tritium concentration in samples collected in 1999 from 74 domestic water supply wells completed in the central High Plains aquifer

[>, greater than; <, less than or equal to; percentages of group in parentheses]

\begin{tabular}{|c|c|c|c|c|c|c|}
\hline $\begin{array}{l}\text { Group, by } \\
\text { nitrate-nitrogen } \\
\text { or tritium } \\
\text { concentration }\end{array}$ & $\begin{array}{c}\text { Number of wells } \\
\text { producing water } \\
\text { with detectable } \\
\text { volatile organic } \\
\text { compounds per } \\
\text { group }\end{array}$ & $\begin{array}{l}\text { Number of wells } \\
\text { producing water } \\
\text { with no detect- } \\
\text { able volatile } \\
\text { organic } \\
\text { compounds per } \\
\text { group }\end{array}$ & $\begin{array}{l}\text { Total number } \\
\text { of wells with } \\
\text { detectable } \\
\text { volatile organic } \\
\text { compounds } \\
\text { per group }\end{array}$ & $\begin{array}{l}\text { Number of wells } \\
\text { producing water } \\
\text { with detectable } \\
\text { pesticides per } \\
\text { group }\end{array}$ & $\begin{array}{l}\text { Number of } \\
\text { wells } \\
\text { producing } \\
\text { water with } \\
\text { no detect- } \\
\text { able pesti- } \\
\text { cides per } \\
\text { group }\end{array}$ & $\begin{array}{l}\text { Total } \\
\text { number of } \\
\text { wells with } \\
\text { detect- } \\
\text { able pesti- } \\
\text { cides per } \\
\text { group }\end{array}$ \\
\hline $\begin{array}{l}\text { Nitrate-nitrogen } \\
\text { concentration } \\
>4.0 \text { milligrams } \\
\text { per liter } \\
\text { (component of } \\
\text { recharge } \\
\text { assumed to be } \\
\text { post-1953) }\end{array}$ & $2(9)$ & $19(91)$ & $21(100)$ & $12(57)$ & $9(43)$ & $21(100)$ \\
\hline $\begin{array}{l}\text { Tritium concen- } \\
\text { tration }<0.5 \text { tri- } \\
\text { tium unit } \\
\text { (recharge } \\
\text { assumed to be } \\
\text { pre-1953 }\end{array}$ & $6(14)$ & 37 (86) & 43 (100) & $4(9)$ & 39 (91) & 43 (100) \\
\hline $\begin{array}{l}\text { Tritium concen- } \\
\text { tration }>0.5 \text { tri- } \\
\text { tium unit } \\
\text { (component of } \\
\text { recharge } \\
\text { assumed to be } \\
\text { post- } 1953\end{array}$ & $1(10)$ & $9(90)$ & $10(100)$ & $2(20)$ & $8(80)$ & $10(100)$ \\
\hline $\begin{array}{l}\text { Total number of } \\
\text { wells }\end{array}$ & $9(12)$ & $65(88)$ & 74 (100) & $18(24)$ & $56(76)$ & 74 (100) \\
\hline
\end{tabular}

Water properties were variable, reflecting the wide range in depths to water, broad spatial distribution, and heterogeneity of the aquifer. Water samples were near neutral to alkaline, well-oxygenated, and relatively hard. Dissolved solids concentrations exceeded the Secondary Maximum Contaminant Level of 500 milligrams per liter in 16 of the 74 wells.

Calcium, from dissolution of calcite, dolomite, and gypsum, was the principal cation in most water samples from the aquifer. Magnesium was present in lesser amounts. Sodium may be from dissolution of sodium-bearing minerals and also may be related to seepage of brines from underlying bedrock units and from disposal of brines from petroleum production.
Sulfate concentrations were generally small, with 3 of 74 samples producing water with sulfate concentrations exceeding the Secondary Maximum Contaminant Level of 250 milligrams per liter. Chloride concentration was generally small, with water from one of the samples exceeding the Secondary Maximum Contaminant Level of 250 milligrams per liter. Fluoride concentration was equal to the Maximum Contaminant Level of 4 milligrams per liter in one sample and equaled or exceeded the Secondary Maximum Contaminant Level of 2 milligrams per liter six samples.

Nitrate concentrations exceeded the Maximum Contaminant Level of 10 milligrams per liter as nitrogen in water from 3 samples. If 2 milligrams per 
liter is used as a threshold for manmade contamination, 45 samples had nitrate concentrations indicative of manmade contamination. Well-oxygenated water and little dissolved organic carbon in the aquifer indicate that nitrate is not likely to be removed from the aquifer by denitrification. Dissolved phosphorus was measured at relatively small concentrations in the aquifer.

Aluminum, arsenic, barium, chromium, molybdenum, selenium, zinc, and uranium were detected in a majority of the water samples. Most detected trace elements were at concentrations substantially less than Maximum Contaminant Levels, although a few samples had concentrations of lead, manganese, and uranium which exceeded Maximum Contaminant Levels or Secondary Maximum Contaminant Levels. Aluminum may have been an artifact of sampling, preservation, and analyses, as equipment blank samples had similar aluminum concentrations as environmental samples. Metals such as chromium, copper, iron, lead, nickel, and zinc can be partly derived from well casings and other plumbing components of the wells. Arsenic, barium, selenium, and uranium were more likely to be from natural sources in the aquifer or underlying geologic units.

Radon gas concentration in ground water in the area appears to be associated with underlying geologic units. The frequencies of radon concentration exceeding 300 picocuries per liter related to underlying geologic units were as follows, by age: Cretaceous-age 89 percent, Triassic and Jurassic 81 percent, and Permian 58 percent. Greater radon concentration in areas underlain by sandstones, shales and limestones of Cretaceous, Triassic, and Jurassic ages may be due to increased concentration of uranium in those units, which are in hydrologic connection with the overlying High Plains aquifer. Lesser radon concentrations in areas underlain by bedrock units of Permian age, may be due to lesser deposition of uranium in the oxidizing conditions prevalent during the deposition of those units.

Nine samples had detectable concentrations of one or more of the following volatile organic compounds: toluene, chloroform, tetrachloroethene, $O$ dichlorobenzene, and $p$-dichlorobenzene. Toluene was the most commonly detected volatile organic compound, being detected in eight samples at concentrations up to 0.16 microgram per liter. Detection of toluene in similar concentrations in quality-control samples indicates that toluene may have been introduced by sampling or analytical procedures.

One or more pesticides were detected in 18 water samples. None of the detected pesticides exceeded Maximum Contaminant Levels. Atrazine was detected in 15 samples whereas deethylatrazine, a metabolite of atrazine, was detected in 17 samples. In 14 of 15 of the samples that contained detectable atrazine, deethylatrazine also was detected. Metolachlor and the metolachlor breakdown products, metolachlor ESA and metolachlor OA, were the second most commonly detected pesticides. Metolachlor was detected in water from five wells, metolachlor ESA was detected in four samples, and metolachlor OA was detected in two samples. Additional detected pesticides included simazine, alachlor ESA, the breakdown product of alachlor; prometon, pendimethalin, and tebuthiuron. Insecticides detected in one sample each included carbaryl, chlorpyrifos, diazinon, and malathion.

The 18 sites with pesticide detections were distributed primarily in the Kansas portion of the central High Plains aquifer. In 14 of 18 samples with one or more detectable pesticides, the depth to water in the sampled wells was less than 200 feet below the land surface. However, pesticides were detected in three samples from wells having depths to water greater than 300 feet.

Tritium concentration can indicate whether ground water has a been recharged in the last 50 years. Ten of 51 samples analyzed for tritium had detected tritium greater than 0.5 tritium unit. Wells producing water with elevated concentrations of tritium or nitrate, indicating recent recharge, generally had well screens less than 250 feet below land surface, whereas wells having screens deeper than 250 feet had lesser concentrations of tritium and nitrate, indicating less likelihood of recent recharge. Detections of volatile organic compounds generally did not coincide with wells having recent recharge, whereas pesticides were much more likely to be detected in water samples indicated by tritium or nitrate concentrations to be recently recharged.

\section{SELECTED REFERENCES}

American Society for Testing and Materials, 1996, Annual book of ASTM standards, section 11: Water and Envi- 
ronmental Technology, v. 11.02, D-5072-92, p. 674676

Brenton, R.W., and Arnett, T.L., 1993, Methods of analysis by the U.S. Geological Survey National Water Quality Laboratory-Determination of dissolved organic carbon by UV-promoted persulfate oxidation and infrared spectrometry: U.S. Geological Survey Open-File Report 92-480, $12 \mathrm{p}$.

Collipp, P.J., Chen, S.Y., and Maitinshy, C.S., 1983, Manganese in infant formulas and learning disability: Ann. Nutr. Metab., vol. 27, p. 488-494.

Connor, B.F., Rose, D.L., Noriega, M.C., Murtagh, L.K., and Abney, S.R., 1998, Methods of analysis by the U.S. Geological Survey National Water Quality Laboratory-Determination of 86 volatile organic compounds in water by gas chromatography/mass spectrometry, including detections less than reporting limits: U.S. Geological Survey Open-File Report 97$829,78 \mathrm{p}$.

Cotzias, G.C., Horiuchi, K., Fuenzalida, S., and Mena, I., 1968, Chronic manganese poisoning: clearance of tissue manganese concentrations with persistence in the neurological picture: Neurology, vol. 18, p. 376382.

Cotzias, G.C., 1974, Levodopa, manganese, and degeneration of the brain: Harvey Lectures, vol. 68, p. 115-147.

Dennehy, K. F., 2000, High Plains regional ground water study: U.S. Geological Survey Fact Sheet FS-091-00, 5 p.

Drever, James I, 1988, The geochemistry of natural waters; 2nd Ed.: Prentice Hall, Englewood, New Jersey, p. 326.

Faires, L.M., 1993, Methods of analysis by the U.S. Geological Survey National Water Quality Laboratory-Determination of metals in water by inductively coupled plasma-mass spectrometry: U.S. Geological Survey Open-File Report 92-634, 28 p.

Fenneman, N. M., 1928, Physical divisions (map), in The national atlas of the United States of America (1970): U.S. Geological Survey, p. 60

Fishman, M.J., 1993, Methods of analysis by the U.S. Geological Survey National Water Quality LaboratoryDetermination of inorganic and organic constituents in water and fluvial sediments: U.S. Geological Survey Open-File Report 93-125, 217 p.

Gilliom, R.J., Alley, W.M., and Gurtz, M.E., 1995, Design of the National Water-Quality Assessment program-occurrence and distribution of water-quality conditions: U.S. Geological Survey Circular 1112, 33 p.

Gorrell, J.M., DiMonte, D., Graham, D. 1996, The role of the environment in Parkinson's Disease: Environmental Health Perspectives, vol. 104, no. 6, p. 652-654.
Gutentag, E. D., Lobmeyer, D. H., and Slagle, S. E., 1981, Geohydrology of southwestern Kansas: Kansas Geological Survey Irrigation Series 7, 73 p.

Gutentag, E. D., Heimes, F.J., Krothe, N.C., Luckey, R.R., and Weeks, J.B., 1984, Geohydrology of the High Plains aquifer in parts of Colorado, Kansas, Nebraska, New Mexico, Oklahoma, South Dakota, Texas, and Wyoming: U.S. Geological Survey Professional Paper 1400-B, 63 p.

Hart Jr., D.L., Hoffman, G.L., and Goemaat, R.L., 1976, Geohydrology of the Oklahoma Panhandle, Beaver, Cimarron, and Texas Counties: U.S. Geological Survey Water Resources Investigations 25-75, p. 21.

Hem, J. D., 1989, Study and interpretation of the chemical characteristics of natural water: U.S. Geological Survey Water-Supply Paper 2254, 264 p.

Hostetler, K.A., and Thurman, E.M., 1999, Determination of chloroacetanilide herbicide metabolites in water using high-performance liquid chromatography/diode array detection and high-performance liquid chromatography/mass spectrometry: U.S. Geological Survey Water-Resources Investigations Report 99-4018-B, 8 p.

Irwin, James H., and Morton, Robert B., 1969, Hydrogeologic information on the Glorieta Sandstone and the Ogallala Formation in the Oklahoma panhandle and adjacent areas as related to underground waste disposal: U.S. Geological Survey Circular 630, p. 11.

Kenny, J.F., 1999, Water use in Kansas, 1990 and 1995: U.S. Geological Survey Fact Sheet 090-99, 4 p.

Koterba, M.T., Wilde, F.D., and Lapham, W.W., 1995, Ground-water data-collection protocols and procedures for the National Water-Quality Assessment programCollection and documentation of water-quality samples and related data: U.S. Geological Survey Open-File Report 95-399, 113 p.

Krothe, N.C., Oliver, J.W., and Weeks, J.B., 1982, Dissolved solids and sodium in water from the High Plains Aquifer in parts of Colorado, Kansas, Nebraska, New Mexico, Oklahoma, South Dakota, Texas, and Wyoming: U.S. Geological Survey Hydrologic Investigations Atlas HA-658, 2 sheets.

Lapham, W.W., Wilde, F.D., and Koterba, M.T., 1995, Ground-water data-collection protocols and procedures for the National Water-Quality Assessment programSelection, installation, and documentation of wells, and collection of related data: U.S. Geological Survey Open-File Report 95-398, 69 p.

Lubin, J.H., and Boice, J.D., Jr., 1997, Lung cancer risk from residential radon: Meta-analysis of eight epidemiologic studies: Journal of the National Cancer Institute, v. 89 , no. 1 , p. $49-57$.

Luckey, Richard L., and Becker, Mark F., 1999, Hydrogeology, water use, and simulation of flow in the High 
Plains aquifer in northwestern Oklahoma, southeastern Colorado, southwestern Kansas, northeastern New Mexico, and northwestern Texas: U.S. Geological Survey Water-Resources Investigations Report 994104, $68 \mathrm{p}$.

Lurry, D.L., 1999, Estimated freshwater withdrawals in Texas, 1990: U.S. Geological Survey Water-Resources Investigations Report 93-4190, 2 sheets.

Mann, H.B., and Whitney, D.R., 1947, On a test of whether one of two random variables is stochastically larger than the other: The Annals of Mathematical Statistics, v. 18., pl 50-60.

McGuire, V.L. and Fischer, B.C., 1999, Water-level changes. 1980 to 1997, and saturated thickness, 19961997. in the High Plains aquifer: U.S. Geological Survey Fact Sheet 124-99, 4 p.

McMahon, Peter, B., 2000, A reconnaissance study of the effect of irrigated agriculture on the water quality in the Ogallala Formation, central High Plains aquifer: U.S. Geological Survey Fact Sheet FS-009-00, 6 p.

Mueller, David K. and Helsel, Dennis R., 1996, Nutrients in the nation's waters too much of a good thing?: U.S. Geological Survey Circular 1136, p. 15

Ostlund, H.G., and Dorsey, H.G., 1975, Rapid electrolytic enrichment of hydrogen gas proportional counting of tritium: International Conference on Low Radioactivity Measurement and Applications, High Tratas, Czechoslovakia, October 1975 [Proceedings], 6 p.

Pepper, I.L., Gerba, C.P., and Brusseau, M.L., eds., 1996, Pollution science: San Diego, California, Academic Press, 397 p.

Reigart, J.R., and Roberts, J.R. (eds.), 1998, Recognition and management of pesticide poisonings: U.S. Environmental Protection Agency \#735-R-98-003, 238 p.

Scott, J.C., 1990, Computerized stratified random site-selection approaches for design of a ground-water-quality sampling network: U.S. Geological Survey WaterResources Investigations Report 90-4101, 109 p.

Smith, H. T. U., 1940, Geologic studies in southwestern Kansas: Kansas Geological Survey Bulletin 34, 212 p.

Sun, R.J, and Johnston, R.H., 1994, Regional aquifersystem analysis program of the U.S. Geological Survey, 1978-1992: U.S. Geological Survey Circular $1099,126 \mathrm{p}$.

Thatcher, L.L., 1962, The distribution of tritium fallout in precipitation over North America: Bulletin of International Association of Scientific Hydrology, v. 7, p. 4858.
Tortorelli, R. L., 2000, Estimated freshwater withdrawals in Oklahoma, 1995: accessed May 15, 2000, at URL http://ok.water.usgs.gov/public/wateruse/wateruse.htm 1

U.S. Census Bureau, 2002 Population estimates: accessed March 21, 2002, at URL http://www.census.gov/population/cen2000/phc-t3/tab01.pdf

U.S. Department of Commerce, 1949-1992, Census of agriculture: U.S. Census Bureau, Agricultural data for 1949, 1954, 1959,1964, 1969,1974, 1978, 1982,1987, and 1992, for Colorado, Kansas, New Mexico, Oklahoma, and Texas.

U.S. Environmental Protection Agency, 1999, 40 CFR Parts 141 and 142, National Primary Drinking Water Regulations, Radon-222, Proposed Rule: Federal Register, vol. 64, no. 211, p. 59245-59378.

2001a, Current drinking water standards: accessed (2001), at URL http://www.epa.gov/safewater/mcl.html.

2001b, What are the health effects of contaminants in drinking water?: accessed April 10, 2001, at URL http://www.epa.gov/safewater/dwh/health.html

U.S. Geological Survey, 2000, National Land Cover Data Base: U.S. Geological Survey on-line dataset accessed December 12, 2000, at URL http://edcwww.cr.usgs.gov/pub/edcuser/vogel/states

U.S. Salinity Laboratory Staff, 1954, Diagnosis and improvement of saline and alkaline soils: U.S. Department of Agriculture Handbook 60, 160 p.

Verschueren, Karel, 1983, Handbook of environmental data on organic chemicals: New York, Van Nostrand Reinhold, $1310 \mathrm{p}$.

Weeks, J.B., Gutentag, E.D., Heimes, F.J., and Luckey, R.R., 1988, Summary of the High Plains regional aquifer-system analysis in parts of Colorado, Kansas, Nebraska, New Mexico, Oklahoma, South Dakota, Texas, and Wyoming: U.S. Geological Survey Professional Paper 1400-A, 30 p.

World Health Organization, 2001, Air quality guidelines, 2nd edition, Chapter 6.8 manganese, 13 p.

Zaugg, S.D., Sandstrom, M.W., Smith, S.G., and Fehlberg, K.M., 1995, Methods of analysis by the U.S. Geological Survey National Water Quality Laboratory-Determination of pesticides in water by C-18 solid-phase extraction and capillary-column gas chromatography/mass spectrometry with selected-ion monitoring: U.S. Geological Survey Open-File Report 95-181, $60 \mathrm{p}$. 
APPENDIX 

Appendix 1. Water-quality data from 74 domestic water-supply wells completed in the central High Plains aquifer

$\left[\mathrm{mg} / \mathrm{L}\right.$, milligrams per liter; $\mu \mathrm{s} / \mathrm{cm}$, microsiemens per centimeter at $25 \mathrm{C}^{\circ}{ }_{\mathrm{C}}^{\circ} \mathrm{C}$, degree Celsius; $\mathrm{CaCo}_{3}$, calcium carbonate; <, less than; N, nitrogen; $\mathrm{P}$, phosphorus; NTU, nephelometric turbity units; $\mu \mathrm{g} / \mathrm{L}$, micrograms per liter; --, no data; E, estimated]

\begin{tabular}{|c|c|c|c|c|c|c|c|c|c|c|c|c|}
\hline STATION & DATE & $\begin{array}{l}\text { TUR- } \\
\text { BID- } \\
\text { ITY } \\
\text { (NTU) }\end{array}$ & $\begin{array}{c}\text { OXYGEN, } \\
\text { DIS- } \\
\text { SOLVED } \\
\text { (MG/L) }\end{array}$ & $\begin{array}{c}\text { PH } \\
\text { WATER } \\
\text { WHOLE } \\
\text { FIELD } \\
\text { (STAND- } \\
\text { ARD } \\
\text { UNITS) }\end{array}$ & $\begin{array}{l}\text { SPE- } \\
\text { CIFIC } \\
\text { CON- } \\
\text { DUCT- } \\
\text { ANCE } \\
\text { (US/CM) }\end{array}$ & $\begin{array}{l}\text { TEMPER- } \\
\text { ATURE } \\
\text { WATER } \\
\text { (DEG C) }\end{array}$ & $\begin{array}{l}\text { CALCIUM } \\
\text { DIS- } \\
\text { SOLVED } \\
\text { (MG/L } \\
\text { AS CA) }\end{array}$ & $\begin{array}{l}\text { MAGNE- } \\
\text { SIUM, } \\
\text { DIS- } \\
\text { SOLVED } \\
\text { (MG/L } \\
\text { AS MG) }\end{array}$ & $\begin{array}{l}\text { POTAS- } \\
\text { SIUM, } \\
\text { DIS- } \\
\text { SOLVED } \\
\text { (MG/L } \\
\text { AS K) }\end{array}$ & $\begin{array}{l}\text { SODIUM, } \\
\text { DIS- } \\
\text { SOLVED } \\
\text { (MG/L } \\
\text { AS NA) }\end{array}$ & $\begin{array}{l}\text { ALKA- } \\
\text { LINITY } \\
\text { WAT DIS } \\
\text { TOT IT } \\
\text { FIELD } \\
\text { MG/L AS } \\
\text { CACO3 }\end{array}$ & $\begin{array}{c}\text { BROMIDE } \\
\text { DIS- } \\
\text { SOLVED } \\
\text { (MG/L } \\
\text { AS BR) }\end{array}$ \\
\hline $\begin{array}{l}344800101324901 \\
345826100580501 \\
351656101161101 \\
351914101204401 \\
352035100293301\end{array}$ & $\begin{array}{l}07-14-99 \\
06-28-99 \\
05-19-99 \\
07-01-99 \\
07-13-99\end{array}$ & $\begin{array}{r}.1 \\
1.2 \\
.5 \\
.2 \\
.2\end{array}$ & $\begin{array}{l}7.0 \\
7.6 \\
6.3 \\
5.4 \\
5.5\end{array}$ & $\begin{array}{l}7.5 \\
7.3 \\
7.5 \\
7.5 \\
7.3\end{array}$ & $\begin{array}{l}502 \\
580 \\
470 \\
504 \\
446\end{array}$ & $\begin{array}{l}16.5 \\
17.4 \\
18.9 \\
18.8 \\
18.0\end{array}$ & $\begin{array}{l}38.6 \\
63.2 \\
39.5 \\
37.9 \\
71.8\end{array}$ & $\begin{array}{l}23.6 \\
7.27 \\
20.2 \\
25.7 \\
6.00\end{array}$ & $\begin{array}{l}5.31 \\
2.36 \\
5.19 \\
6.17 \\
1.13\end{array}$ & $\begin{array}{l}32.7 \\
45.5 \\
32.6 \\
34.2 \\
31.1\end{array}$ & $\begin{array}{l}219 \\
219 \\
230 \\
242 \\
198\end{array}$ & $\begin{array}{l}.10 \\
.19 \\
.07 \\
.08 \\
.17\end{array}$ \\
\hline $\begin{array}{l}352249100425401 \\
352513101372101 \\
352909101084001 \\
353110100550401 \\
353941102350201\end{array}$ & $\begin{array}{l}06-30-99 \\
05-20-99 \\
07-01-99 \\
06-29-99 \\
07-15-99\end{array}$ & $\begin{array}{r}.3 \\
.6 \\
.2 \\
.2 \\
1.1\end{array}$ & $\begin{array}{l}7.8 \\
7.0 \\
6.8 \\
6.5 \\
8.2\end{array}$ & $\begin{array}{l}7.5 \\
7.7 \\
7.7 \\
7.6 \\
7.7\end{array}$ & $\begin{array}{r}335 \\
395 \\
1640 \\
800 \\
440\end{array}$ & $\begin{array}{l}17.7 \\
19.5 \\
18.5 \\
18.1 \\
20.0\end{array}$ & $\begin{array}{l}55.9 \\
33.4 \\
44.1 \\
42.5 \\
23.3\end{array}$ & $\begin{array}{l}4.42 \\
23.7 \\
17.0 \\
21.9 \\
23.4\end{array}$ & $\begin{array}{l}1.22 \\
5.20 \\
4.27 \\
5.83 \\
4.74\end{array}$ & $\begin{array}{r}9.6 \\
11.3 \\
275 \\
83.8 \\
42.2\end{array}$ & $\begin{array}{l}156 \\
163 \\
182 \\
223 \\
191\end{array}$ & $\begin{array}{l}.04 \\
.12 \\
.17 \\
.12 \\
.13\end{array}$ \\
\hline $\begin{array}{l}354248100501501 \\
354331102183601 \\
354348102543601 \\
354656099480301 \\
354728102295901\end{array}$ & $\begin{array}{l}07-19-99 \\
06-23-99 \\
07-21-99 \\
05-17-99 \\
07-16-99\end{array}$ & $\begin{array}{r}1.0 \\
1.2 \\
.1 \\
.5 \\
.5\end{array}$ & $\begin{array}{l}7.1 \\
5.6 \\
7.1 \\
6.8 \\
5.6\end{array}$ & $\begin{array}{l}7.6 \\
7.7 \\
7.7 \\
7.3 \\
7.6\end{array}$ & $\begin{array}{l}451 \\
429 \\
368 \\
430 \\
475\end{array}$ & $\begin{array}{l}18.8 \\
21.1 \\
17.9 \\
17.5 \\
18.1\end{array}$ & $\begin{array}{l}37.1 \\
33.7 \\
34.9 \\
66.8 \\
33.8\end{array}$ & $\begin{array}{l}24.7 \\
20.1 \\
16.4 \\
4.24 \\
25.1\end{array}$ & $\begin{array}{l}<.10 \\
5.36 \\
2.84 \\
1.44 \\
4.98\end{array}$ & $\begin{array}{l}33.2 \\
25.1 \\
19.3 \\
20.5 \\
28.1\end{array}$ & $\begin{array}{l}192 \\
180 \\
163 \\
194 \\
194\end{array}$ & $\begin{array}{l}.08 \\
.12 \\
.10 \\
.05 \\
.18\end{array}$ \\
\hline $\begin{array}{l}354918102020901 \\
355701100313001 \\
355852101274101 \\
355916103215201 \\
360703102361901\end{array}$ & $\begin{array}{l}06-23-99 \\
05-18-99 \\
07-02-99 \\
06-25-99 \\
06-22-99\end{array}$ & $\begin{array}{r}5.5 \\
3.8 \\
.2 \\
8.5 \\
.6\end{array}$ & $\begin{array}{l}4.6 \\
7.4 \\
6.8 \\
7.2 \\
7.2\end{array}$ & $\begin{array}{l}8.0 \\
7.4 \\
7.6 \\
7.7 \\
7.7\end{array}$ & $\begin{array}{r}509 \\
527 \\
445 \\
1380 \\
463\end{array}$ & $\begin{array}{l}19.9 \\
17.6 \\
17.7 \\
15.5 \\
17.7\end{array}$ & $\begin{array}{l}24.5 \\
49.0 \\
38.2 \\
54.8 \\
37.3\end{array}$ & $\begin{array}{l}15.3 \\
25.7 \\
24.2 \\
54.1 \\
27.6\end{array}$ & $\begin{array}{l}5.41 \\
4.73 \\
5.04 \\
6.93 \\
7.16\end{array}$ & $\begin{array}{r}61.4 \\
19.8 \\
18.2 \\
128 \\
12.5\end{array}$ & $\begin{array}{l}222 \\
202 \\
198 \\
224 \\
176\end{array}$ & $\begin{array}{r}.10 \\
.07 \\
.07 \\
1.69 \\
.14\end{array}$ \\
\hline $\begin{array}{l}360838102560301 \\
360944100162101 \\
361014100221001 \\
361049100564901 \\
361054101393601\end{array}$ & $\begin{array}{l}06-24-99 \\
04-12-99 \\
04-08-99 \\
05-21-99 \\
06-21-99\end{array}$ & $\begin{array}{r}.1 \\
.4 \\
.9 \\
1.3 \\
1.5\end{array}$ & $\begin{array}{l}5.7 \\
5.3 \\
5.6 \\
8.3 \\
3.2\end{array}$ & $\begin{array}{l}7.6 \\
7.8 \\
7.5 \\
7.7 \\
7.6\end{array}$ & $\begin{array}{l}406 \\
497 \\
635 \\
648 \\
551\end{array}$ & $\begin{array}{l}16.8 \\
16.1 \\
16.2 \\
18.3 \\
18.0\end{array}$ & $\begin{array}{l}40.0 \\
46.2 \\
57.8 \\
41.8 \\
43.8\end{array}$ & $\begin{array}{l}19.6 \\
23.1 \\
30.0 \\
27.2 \\
30.5\end{array}$ & $\begin{array}{l}3.56 \\
4.27 \\
4.00 \\
5.53 \\
6.08\end{array}$ & $\begin{array}{l}13.9 \\
26.7 \\
29.3 \\
54.9 \\
26.2\end{array}$ & $\begin{array}{l}170 \\
211 \\
212 \\
214 \\
209\end{array}$ & $\begin{array}{l}.10 \\
.09 \\
.17 \\
.10 \\
.16\end{array}$ \\
\hline $\begin{array}{l}361114099420501 \\
361517102065301 \\
362115101173901 \\
362134102035101 \\
362615100435801\end{array}$ & $\begin{array}{l}07-22-99 \\
05-26-99 \\
05-25-99 \\
05-25-99 \\
05-24-99\end{array}$ & $\begin{array}{r}8.6 \\
1.2 \\
.3 \\
.1 \\
.2\end{array}$ & $\begin{array}{l}8.3 \\
5.5 \\
7.3 \\
7.1 \\
7.3\end{array}$ & $\begin{array}{l}7.3 \\
7.8 \\
7.6 \\
7.9 \\
7.6\end{array}$ & $\begin{array}{l}526 \\
529 \\
645 \\
458 \\
573\end{array}$ & $\begin{array}{l}16.7 \\
17.5 \\
17.6 \\
18.1 \\
17.5\end{array}$ & $\begin{array}{l}96.6 \\
35.5 \\
50.3 \\
27.6 \\
35.4\end{array}$ & $\begin{array}{l}8.61 \\
23.1 \\
26.6 \\
26.0 \\
21.5\end{array}$ & $\begin{array}{l}2.09 \\
5.96 \\
5.38 \\
5.39 \\
5.56\end{array}$ & $\begin{array}{l}18.9 \\
43.1 \\
37.5 \\
30.9 \\
51.4\end{array}$ & $\begin{array}{l}198 \\
197 \\
173 \\
189 \\
197\end{array}$ & $\begin{array}{l}.08 \\
.19 \\
.36 \\
.12 \\
.10\end{array}$ \\
\hline $\begin{array}{l}362744102334901 \\
363057101384701 \\
363104100035501 \\
363154099310401 \\
363157102565601\end{array}$ & $\begin{array}{l}07-20-99 \\
05-27-99 \\
04-09-99 \\
07-22-99 \\
04-16-99\end{array}$ & $\begin{array}{l}.4 \\
.2 \\
.1 \\
.2 \\
.1\end{array}$ & $\begin{array}{l}2.4 \\
6.8 \\
7.3 \\
6.7 \\
7.1\end{array}$ & $\begin{array}{l}8.3 \\
7.7 \\
7.6 \\
7.4 \\
8.1\end{array}$ & $\begin{array}{l}740 \\
414 \\
468 \\
471 \\
413\end{array}$ & $\begin{array}{l}16.8 \\
16.9 \\
16.7 \\
16.4 \\
15.4\end{array}$ & $\begin{array}{l}7.37 \\
32.8 \\
49.9 \\
72.4 \\
45.1\end{array}$ & $\begin{array}{l}15.6 \\
21.3 \\
20.1 \\
7.92 \\
18.8\end{array}$ & $\begin{array}{l}5.48 \\
4.26 \\
1.37 \\
1.76 \\
2.81\end{array}$ & $\begin{array}{l}141 \\
24.1 \\
16.6 \\
21.8 \\
14.3\end{array}$ & $\begin{array}{l}310 \\
172 \\
221 \\
224 \\
172\end{array}$ & $\begin{array}{l}.21 \\
.06 \\
.10 \\
.07 \\
.12\end{array}$ \\
\hline $\begin{array}{l}363239100301801 \\
363427102440401 \\
364219101394101 \\
364411102321201 \\
365223102113001\end{array}$ & $\begin{array}{l}04-06-99 \\
04-15-99 \\
06-11-99 \\
06-10-99 \\
04-14-99\end{array}$ & $\begin{array}{l}.1 \\
.7 \\
.7 \\
.1 \\
.1\end{array}$ & $\begin{array}{l}5.6 \\
7.4 \\
6.9 \\
7.5 \\
7.5\end{array}$ & $\begin{array}{l}7.8 \\
8.1 \\
7.8 \\
7.7 \\
7.9\end{array}$ & $\begin{array}{l}569 \\
498 \\
503 \\
533 \\
464\end{array}$ & $\begin{array}{l}17.0 \\
15.5 \\
17.2 \\
16.5 \\
16.8\end{array}$ & $\begin{array}{l}31.4 \\
48.3 \\
29.1 \\
48.2 \\
30.0\end{array}$ & $\begin{array}{l}15.2 \\
23.7 \\
27.3 \\
26.0 \\
31.8\end{array}$ & $\begin{array}{l}4.30 \\
3.51 \\
6.80 \\
4.07 \\
5.00\end{array}$ & $\begin{array}{l}72.9 \\
18.5 \\
39.3 \\
25.1 \\
20.7\end{array}$ & $\begin{array}{l}217 \\
161 \\
214 \\
173 \\
163\end{array}$ & $\begin{array}{l}.04 \\
.26 \\
.10 \\
.20 \\
.20\end{array}$ \\
\hline $\begin{array}{l}365422101083701 \\
365445100381901 \\
365821101375301 \\
365934101573001 \\
370358100510301\end{array}$ & $\begin{array}{l}06-11-99 \\
04-07-99 \\
05-28-99 \\
04-13-99 \\
04-15-99\end{array}$ & $\begin{array}{l}.1 \\
.1 \\
.1 \\
.1 \\
.7\end{array}$ & $\begin{array}{l}6.8 \\
8.5 \\
4.8 \\
1.8 \\
3.7\end{array}$ & $\begin{array}{l}7.6 \\
7.6 \\
7.4 \\
7.5 \\
7.6\end{array}$ & $\begin{array}{l}482 \\
572 \\
732 \\
932 \\
509\end{array}$ & $\begin{array}{l}17.0 \\
16.9 \\
17.5 \\
17.5 \\
16.7\end{array}$ & $\begin{array}{l}56.8 \\
54.5 \\
74.9 \\
50.7 \\
48.2\end{array}$ & $\begin{array}{l}23.0 \\
22.6 \\
32.2 \\
32.3 \\
21.7\end{array}$ & $\begin{array}{l}3.73 \\
4.02 \\
4.81 \\
5.23 \\
3.16\end{array}$ & $\begin{array}{r}12.0 \\
31.6 \\
44.4 \\
119 \\
25.9\end{array}$ & $\begin{array}{l}171 \\
180 \\
230 \\
321 \\
184\end{array}$ & $\begin{array}{l}.23 \\
.14 \\
.15 \\
.20 \\
.13\end{array}$ \\
\hline $\begin{array}{l}370458101514401 \\
370724100281601 \\
371738101220301 \\
372534100443501 \\
372649101344701\end{array}$ & $\begin{array}{l}04-22-99 \\
04-23-99 \\
04-20-99 \\
04-16-99 \\
04-19-99\end{array}$ & $\begin{array}{r}.8 \\
.2 \\
.1 \\
.3 \\
2.4\end{array}$ & $\begin{array}{l}5.1 \\
4.2 \\
6.0 \\
2.4 \\
5.2\end{array}$ & $\begin{array}{l}7.5 \\
7.5 \\
7.5 \\
7.6 \\
7.6\end{array}$ & $\begin{array}{l}539 \\
930 \\
514 \\
574 \\
457\end{array}$ & $\begin{array}{l}14.7 \\
14.0 \\
18.1 \\
17.1 \\
17.6\end{array}$ & $\begin{array}{l}64.3 \\
126 \\
50.1 \\
59.1 \\
43.3\end{array}$ & $\begin{array}{l}14.0 \\
15.7 \\
23.4 \\
14.5 \\
14.9\end{array}$ & $\begin{array}{l}2.10 \\
3.65 \\
3.59 \\
3.81 \\
3.27\end{array}$ & $\begin{array}{l}23.9 \\
40.0 \\
24.1 \\
34.4 \\
29.2\end{array}$ & $\begin{array}{l}168 \\
149 \\
164 \\
168 \\
155\end{array}$ & $\begin{array}{l}.21 \\
.10 \\
.15 \\
.13 \\
.11\end{array}$ \\
\hline $\begin{array}{l}372956099512201 \\
373229101193201 \\
373345101070801 \\
373507102162001 \\
373527100312701\end{array}$ & $\begin{array}{l}05-26-99 \\
04-21-99 \\
04-06-99 \\
06-09-99 \\
04-09-99\end{array}$ & $\begin{array}{r}.2 \\
.3 \\
.6 \\
.1 \\
3.6\end{array}$ & $\begin{array}{l}5.4 \\
3.6 \\
5.2 \\
7.0 \\
5.7\end{array}$ & $\begin{array}{l}7.5 \\
7.5 \\
7.6 \\
7.6 \\
7.7\end{array}$ & $\begin{array}{l}435 \\
679 \\
528 \\
566 \\
365\end{array}$ & $\begin{array}{l}17.3 \\
16.9 \\
17.8 \\
15.4 \\
17.0\end{array}$ & $\begin{array}{l}44.6 \\
67.5 \\
58.5 \\
53.3 \\
46.2\end{array}$ & $\begin{array}{l}15.9 \\
31.4 \\
17.6 \\
17.2 \\
8.40\end{array}$ & $\begin{array}{l}3.86 \\
5.11 \\
3.11 \\
3.49 \\
3.27\end{array}$ & $\begin{array}{l}23.7 \\
50.1 \\
26.4 \\
37.5 \\
28.3\end{array}$ & $\begin{array}{l}190 \\
172 \\
166 \\
138 \\
142\end{array}$ & $\begin{array}{l}.08 \\
.23 \\
.24 \\
.21 \\
.09\end{array}$ \\
\hline $\begin{array}{l}373559102314901 \\
373732099291201 \\
374535102110301 \\
374650100181901 \\
375129100532301\end{array}$ & $\begin{array}{l}06-09-99 \\
05-19-99 \\
06-08-99 \\
04-14-99 \\
04-18-99\end{array}$ & $\begin{array}{r}.2 \\
11.3 \\
.7 \\
2.3\end{array}$ & $\begin{array}{l}6.8 \\
7.6 \\
6.0 \\
6.0 \\
5.4\end{array}$ & $\begin{array}{l}7.8 \\
7.5 \\
7.7 \\
7.5 \\
7.6\end{array}$ & $\begin{array}{l}462 \\
444 \\
569 \\
602 \\
377\end{array}$ & $\begin{array}{l}16.0 \\
19.2 \\
18.6 \\
15.8 \\
17.9\end{array}$ & $\begin{array}{l}47.6 \\
64.0 \\
67.6 \\
74.7 \\
46.7\end{array}$ & $\begin{array}{l}11.1 \\
9.01 \\
14.8 \\
12.8 \\
8.21\end{array}$ & $\begin{array}{l}3.80 \\
2.88 \\
<.10 \\
.76 \\
2.57\end{array}$ & $\begin{array}{l}33.2 \\
16.5 \\
25.5 \\
22.1 \\
19.3\end{array}$ & $\begin{array}{l}134 \\
172 \\
132 \\
154 \\
155\end{array}$ & $\begin{array}{l}.15 \\
.06 \\
.18 \\
.07 \\
.06\end{array}$ \\
\hline $\begin{array}{l}375447099245001 \\
375828101111801 \\
380331100352801 \\
382947100443201 \\
383008101315601\end{array}$ & $\begin{array}{l}05-19-99 \\
04-07-99 \\
04-17-99 \\
04-08-99 \\
04-28-99\end{array}$ & $\begin{array}{r}.2 \\
.4 \\
1.1 \\
.2 \\
.2\end{array}$ & $\begin{array}{l}.3 \\
2.4 \\
5.7 \\
4.3 \\
6.2\end{array}$ & $\begin{array}{l}7.3 \\
7.5 \\
7.5 \\
7.4 \\
7.8\end{array}$ & $\begin{array}{r}1390 \\
1300 \\
981 \\
819 \\
392\end{array}$ & $\begin{array}{l}15.5 \\
16.4 \\
14.9 \\
15.4 \\
13.5\end{array}$ & $\begin{array}{r}139 \\
105 \\
82.9 \\
75.8 \\
43.9\end{array}$ & $\begin{array}{l}38.4 \\
55.5 \\
36.5 \\
31.1 \\
13.3\end{array}$ & $\begin{array}{l}5.49 \\
6.51 \\
7.15 \\
7.58 \\
3.69\end{array}$ & $\begin{array}{r}114 \\
67.2 \\
54.2 \\
54.8 \\
15.0\end{array}$ & $\begin{array}{l}197 \\
154 \\
217 \\
208 \\
133\end{array}$ & $\begin{array}{l}.30 \\
.35 \\
.29 \\
.26 \\
.12\end{array}$ \\
\hline $\begin{array}{l}383758101195801 \\
383919101040101 \\
385210100164501 \\
385904099522201 \\
390622101003201\end{array}$ & $\begin{array}{l}05-22-99 \\
04-29-99 \\
06-07-99 \\
05-24-99 \\
05-23-99\end{array}$ & $\begin{array}{r}.1 \\
1.3 \\
.1 \\
.5 \\
.2\end{array}$ & $\begin{array}{l}5.7 \\
6.7 \\
7.5 \\
4.7 \\
6.5\end{array}$ & $\begin{array}{l}7.5 \\
7.6 \\
7.4 \\
7.2 \\
7.7\end{array}$ & $\begin{array}{l}706 \\
494 \\
477 \\
780 \\
591\end{array}$ & $\begin{array}{r}15.4 \\
13.9 \\
17.0 \\
15.5 \\
\mathrm{E} 16.6\end{array}$ & $\begin{array}{c}66.8 \\
54.1 \\
59.7 \\
105 \\
56.0\end{array}$ & $\begin{array}{l}26.9 \\
19.9 \\
12.3 \\
14.7 \\
20.7\end{array}$ & $\begin{array}{l}6.01 \\
4.81 \\
2.99 \\
5.66 \\
5.96\end{array}$ & $\begin{array}{l}34.6 \\
29.6 \\
18.6 \\
28.4 \\
30.5\end{array}$ & $\begin{array}{l}138 \\
151 \\
191 \\
247 \\
181\end{array}$ & $\begin{array}{l}.47 \\
.31 \\
.10 \\
.16 \\
.27\end{array}$ \\
\hline $\begin{array}{l}390830102052001 \\
390838100411701 \\
391044100051001 \\
391921101385501\end{array}$ & $\begin{array}{l}04-30-99 \\
05-21-99 \\
05-25-99 \\
05-20-99\end{array}$ & $\begin{array}{l}.5 \\
.6 \\
.3 \\
.2\end{array}$ & $\begin{array}{l}7.4 \\
4.0 \\
5.1 \\
5.3\end{array}$ & $\begin{array}{l}7.9 \\
7.5 \\
7.5 \\
7.8\end{array}$ & $\begin{array}{l}285 \\
459 \\
431 \\
365\end{array}$ & $\begin{array}{l}12.1 \\
15.5 \\
14.8 \\
15.7\end{array}$ & $\begin{array}{l}34.9 \\
47.9 \\
59.7 \\
36.4\end{array}$ & $\begin{array}{l}7.46 \\
18.6 \\
11.5 \\
11.4\end{array}$ & $\begin{array}{l}3.00 \\
6.29 \\
4.33 \\
3.95\end{array}$ & $\begin{array}{r}13.5 \\
15.9 \\
6.8 \\
30.3\end{array}$ & $\begin{array}{l}122 \\
208 \\
170 \\
170\end{array}$ & $\begin{array}{l}.05 \\
.07 \\
.07 \\
.06\end{array}$ \\
\hline
\end{tabular}




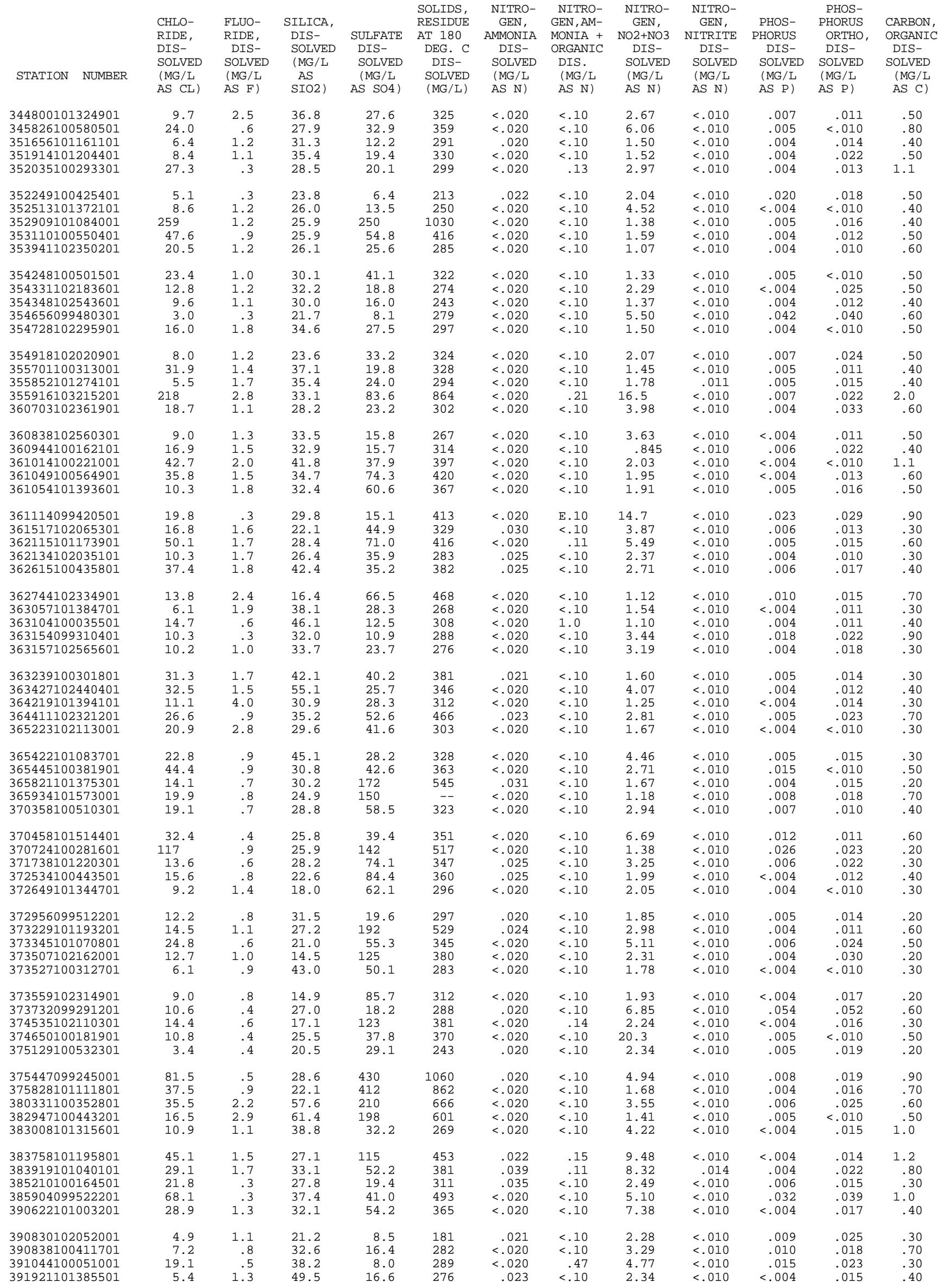




\begin{tabular}{|c|c|c|c|c|c|c|c|c|c|c|c|c|}
\hline STATION & $\begin{array}{l}\text { ALUM- } \\
\text { INUM, } \\
\text { DIS- } \\
\text { SOLVED } \\
\text { (UG/L } \\
\text { AS AL) }\end{array}$ & $\begin{array}{l}\text { ANTI- } \\
\text { MONY, } \\
\text { DIS- } \\
\text { SOLVED } \\
\text { (UG/L } \\
\text { AS SB) }\end{array}$ & $\begin{array}{c}\text { ARSENIC } \\
\text { DIS- } \\
\text { SOLVED } \\
\text { (UG/L } \\
\text { AS AS) }\end{array}$ & $\begin{array}{c}\text { BARIUM, } \\
\text { DIS- } \\
\text { SOLVED } \\
\text { (UG/L } \\
\text { AS BA) }\end{array}$ & $\begin{array}{l}\text { BERYL- } \\
\text { LIUM, } \\
\text { DIS- } \\
\text { SOLVED } \\
\text { (UG/L } \\
\text { AS BE) }\end{array}$ & $\begin{array}{l}\text { CADMIUM } \\
\text { DIS- } \\
\text { SOLVED } \\
\text { (UG/L } \\
\text { AS CD) }\end{array}$ & $\begin{array}{l}\text { CHRO- } \\
\text { MIUM, } \\
\text { DIS- } \\
\text { SOLVED } \\
\text { (UG/L } \\
\text { AS CR) }\end{array}$ & $\begin{array}{c}\text { COBALT, } \\
\text { DIS- } \\
\text { SOLVED } \\
\text { (UG/L } \\
\text { AS CO) }\end{array}$ & $\begin{array}{l}\text { COPPER, } \\
\text { DIS- } \\
\text { SOLVED } \\
\text { (UG/L } \\
\text { AS CU) }\end{array}$ & $\begin{array}{l}\text { IRON, } \\
\text { DIS- } \\
\text { SOLVED } \\
\text { (UG/L } \\
\text { AS FE) }\end{array}$ & $\begin{array}{l}\text { LEAD, } \\
\text { DIS- } \\
\text { SOLVED } \\
\text { (UG/L } \\
\text { AS PB) }\end{array}$ & $\begin{array}{l}\text { MANGA- } \\
\text { NESE, } \\
\text { DIS- } \\
\text { SOLVED } \\
\text { (UG/L } \\
\text { AS MN) }\end{array}$ \\
\hline 344800101324901 & $<1$ & $<1.00$ & 5.6 & 89.8 & $<1.00$ & $<1.00$ & 1.1 & $<1.00$ & $<1.0$ & $<10$ & $<1.00$ & $<1.0$ \\
\hline 345826100580501 & $<1$ & $<1.00$ & 3.0 & 92.1 & $<1.00$ & $<1.00$ & $<1.0$ & $<1.00$ & $<1.0$ & $<10$ & $<1.00$ & $<1.0$ \\
\hline 351656101161101 & 5 & $<1.00$ & 1.6 & 116 & $<1.00$ & $<1.00$ & 2.7 & $<1.00$ & $<1.0$ & $<10$ & $<1.00$ & $<1.0$ \\
\hline 351914101204401 & $<1$ & $<1.00$ & 1.4 & 160 & $<1.00$ & $<1.00$ & 5.2 & $<1.00$ & 2.8 & $<10$ & 1.89 & $<1.0$ \\
\hline 352035100293301 & $<1$ & $<1.00$ & 2.1 & 248 & $<1.00$ & $<1.00$ & $<1.0$ & $<1.00$ & 6.3 & $<10$ & $<1.00$ & $<1.0$ \\
\hline 352249100425401 & $<1$ & $<1.00$ & 2.0 & 560 & $<1.00$ & $<1.00$ & $<1.0$ & $<1.00$ & $<1.0$ & $<10$ & $<1.00$ & $<1.0$ \\
\hline 352513101372101 & 5 & $<1.00$ & $<1.0$ & 157 & $<1.00$ & $<1.00$ & $<1.0$ & $<1.00$ & $<1.0$ & $<10$ & $<1.00$ & $<1.0$ \\
\hline 352909101084001 & $<1$ & $<1.00$ & 3.4 & 36.9 & $<1.00$ & $<1.00$ & 3.5 & $<1.00$ & $<1.0$ & $<10$ & $<1.00$ & 4.4 \\
\hline 353110100550401 & $<1$ & $<1.00$ & 3.2 & 64.4 & $<1.00$ & $<1.00$ & 3.5 & $<1.00$ & 2.3 & $<10$ & $<1.00$ & $<1.0$ \\
\hline 353941102350201 & $<1$ & $<1.00$ & 2.8 & 102 & $<1.00$ & $<1.00$ & $<1.0$ & $<1.00$ & $<1.0$ & $<10$ & $<1.00$ & $<1.0$ \\
\hline 354248100501501 & $<1$ & $<1.00$ & 1.6 & 67.7 & $<1.00$ & $<1.00$ & 1.2 & $<1.00$ & $<1.0$ & $<10$ & $<1.00$ & $<1.0$ \\
\hline 354331102183601 & $<1$ & $<1.00$ & 3.3 & 124 & $<1.00$ & $<1.00$ & $<1.0$ & $<1.00$ & $<1.0$ & $<10$ & $<1.00$ & $<1.0$ \\
\hline 354348102543601 & $<1$ & $<1.00$ & 2.3 & 161 & $<1.00$ & $<1.00$ & $<1.0$ & $<1.00$ & $<1.0$ & $<10$ & $<1.00$ & $<1.0$ \\
\hline 354656099480301 & 6 & $<1.00$ & 3.5 & 558 & $<1.00$ & $<1.00$ & $<1.0$ & $<1.00$ & 1.2 & $<10$ & $<1.00$ & $<1.0$ \\
\hline 354728102295901 & $<1$ & $<1.00$ & 1.9 & 85.2 & $<1.00$ & $<1.00$ & 2.2 & $<1.00$ & $<1.0$ & $<10$ & $<1.00$ & $<1.0$ \\
\hline 354918102020901 & $<1$ & $<1.00$ & $<1.0$ & 49.7 & $<1.00$ & $<1.00$ & 2.2 & $<1.00$ & $<1.0$ & $<10$ & $<1.00$ & $<1.0$ \\
\hline 355701100313001 & 5 & $<1.00$ & 1.2 & 150 & $<1.00$ & $<1.00$ & 1.0 & $<1.00$ & $<1.0$ & $<10$ & $<1.00$ & $<1.0$ \\
\hline 355852101274101 & $<1$ & $<1.00$ & 1.6 & 103 & $<1.00$ & $<1.00$ & 2.0 & $<1.00$ & $<1.0$ & $<10$ & $<1.00$ & $<1.0$ \\
\hline 355916103215201 & 1 & $<1.00$ & 3.6 & 109 & $<1.00$ & $<1.00$ & $<1.0$ & $<1.00$ & 4.8 & $<10$ & $<1.00$ & 1.2 \\
\hline 360703102361901 & $<1$ & $<1.00$ & 2.4 & 121 & $<1.00$ & $<1.00$ & $<1.0$ & $<1.00$ & $<1.0$ & $<10$ & $<1.00$ & $<1.0$ \\
\hline 360838102560301 & $<1$ & $<1.00$ & 1.9 & 117 & $<1.00$ & $<1.00$ & $<1.0$ & $<1.00$ & $<1.0$ & $<10$ & $<1.00$ & $<1.0$ \\
\hline 360944100162101 & 4 & $<1.00$ & 2.8 & 248 & $<1.00$ & $<1.00$ & 3.5 & $<1.00$ & $<1.0$ & $<10$ & $<1.00$ & $<1.0$ \\
\hline 361014100221001 & 3 & $<1.00$ & 3.0 & 117 & $<1.00$ & $<1.00$ & 1.1 & $<1.00$ & $<1.0$ & $<10$ & $<1.00$ & $<1.0$ \\
\hline 361049100564901 & 3 & $<1.00$ & 1.6 & 76.8 & $<1.00$ & $<1.00$ & 3.2 & $<1.00$ & $<1.0$ & 10 & $<1.00$ & $<1.0$ \\
\hline 361054101393601 & $<1$ & $<1.00$ & 2.1 & 51.8 & $<1.00$ & $<1.00$ & 1.3 & $<1.00$ & $<1.0$ & $<10$ & $<1.00$ & $<1.0$ \\
\hline 361114099420501 & $<1$ & $<1.00$ & 1.8 & 385 & $<1.00$ & $<1.00$ & $<1.0$ & $<1.00$ & $<1.0$ & $<10$ & $<1.00$ & $<1.0$ \\
\hline 361517102065301 & 5 & $<1.00$ & $<1.0$ & 58.5 & $<1.00$ & $<1.00$ & 3.3 & $<1.00$ & $<1.0$ & $<10$ & $<1.00$ & $<1.0$ \\
\hline 362115101173901 & 5 & $<1.00$ & 2.4 & 49.6 & $<1.00$ & $<1.00$ & 1.8 & $<1.00$ & $<1.0$ & $<10$ & $<1.00$ & $<1.0$ \\
\hline 362134102035101 & 6 & $<1.00$ & 1.4 & 46.6 & $<1.00$ & $<1.00$ & 1.8 & $<1.00$ & 1.0 & $<10$ & $<1.00$ & $<1.0$ \\
\hline 362615100435801 & 4 & $<1.00$ & 5.5 & 81.5 & $<1.00$ & $<1.00$ & 3.9 & $<1.00$ & 2.3 & $<10$ & $<1.00$ & $<1.0$ \\
\hline 362744102334901 & $<1$ & $<1.00$ & 7.6 & 34.8 & $<1.00$ & $<1.00$ & -- & $<1.00$ & $<1.0$ & $<10$ & $<1.00$ & $<1.0$ \\
\hline 363057101384701 & 6 & $<1.00$ & 5.2 & 47.0 & $<1.00$ & $<1.00$ & 1.2 & $<1.00$ & $<1.0$ & $<10$ & $<1.00$ & $<1.0$ \\
\hline 363104100035501 & 2 & $<1.00$ & 4.5 & 188 & $<1.00$ & $<1.00$ & $<1.0$ & $<1.00$ & $<1.0$ & $<10$ & $<1.00$ & $<1.0$ \\
\hline 363154099310401 & $<1$ & $<1.00$ & 2.9 & 220 & $<1.00$ & $<1.00$ & $<1.0$ & $<1.00$ & $<1.0$ & $<10$ & $<1.00$ & $<1.0$ \\
\hline 363157102565601 & 4 & $<1.00$ & 2.0 & 138 & $<1.00$ & $<1.00$ & 1.1 & $<1.00$ & 1.9 & $<10$ & 2.29 & $<1.0$ \\
\hline 363239100301801 & 3 & $<1.00$ & 9.7 & 104 & $<1.00$ & $<1.00$ & 1.8 & $<1.00$ & 1.2 & $<10$ & $<1.00$ & $<1.0$ \\
\hline 363427102440401 & 5 & $<1.00$ & 2.6 & 97.9 & $<1.00$ & $<1.00$ & 1.5 & $<1.00$ & $<1.0$ & $<10$ & $<1.00$ & $<1.0$ \\
\hline 364219101394101 & $<1$ & $<1.00$ & 6.0 & 86.1 & $<1.00$ & $<1.00$ & 1.2 & $<1.00$ & $<1.0$ & $<10$ & $<1.00$ & $<1.0$ \\
\hline 364411102321201 & $<1$ & $<1.00$ & 2.8 & 50.3 & $<1.00$ & $<1.00$ & $<1.0$ & $<1.00$ & $<1.0$ & $<10$ & $<1.00$ & $<1.0$ \\
\hline 365223102113001 & 4 & $<1.00$ & 1.4 & 58.7 & $<1.00$ & $<1.00$ & 1.1 & $<1.00$ & 2.2 & $<10$ & $<1.00$ & $<1.0$ \\
\hline 365422101083701 & 1 & $<1.00$ & 3.5 & 79.2 & $<1.00$ & $<1.00$ & 3.7 & $<1.00$ & $<1.0$ & $<10$ & $<1.00$ & $<1.0$ \\
\hline 365445100381901 & 3 & $<1.00$ & 4.2 & 72.7 & $<1.00$ & $<1.00$ & 2.4 & $<1.00$ & $<1.0$ & $<10$ & $<1.00$ & $<1.0$ \\
\hline 365821101375301 & 5 & $<1.00$ & 1.5 & 42.4 & $<1.00$ & $<1.00$ & 1.4 & $<1.00$ & $<1.0$ & $<10$ & $<1.00$ & $<1.0$ \\
\hline 365934101573001 & 4 & $<1.00$ & $<1.0$ & 21.5 & $<1.00$ & $<1.00$ & $<1.0$ & $<1.00$ & 2.5 & $<10$ & $<1.00$ & $<1.0$ \\
\hline 370358100510301 & 4 & $<1.00$ & 1.5 & 47.4 & $<1.00$ & $<1.00$ & 2.2 & $<1.00$ & $<1.0$ & $<10$ & $<1.00$ & $<1.0$ \\
\hline 370458101514401 & 4 & $<1.00$ & 2.1 & 79.1 & $<1.00$ & $<1.00$ & 1.8 & $<1.00$ & $<1.0$ & $<10$ & $<1.00$ & $<1.0$ \\
\hline 370724100281601 & 4 & $<1.00$ & 2.9 & 90.4 & $<1.00$ & $<1.00$ & 1.9 & $<1.00$ & $<1.0$ & $<10$ & $<1.00$ & $<1.0$ \\
\hline 371738101220301 & 4 & $<1.00$ & 1.8 & 41.0 & $<1.00$ & $<1.00$ & 1.9 & $<1.00$ & $<1.0$ & $<10$ & $<1.00$ & $<1.0$ \\
\hline 372534100443501 & 5 & $<1.00$ & 1.4 & 47.2 & $<1.00$ & $<1.00$ & $<1.0$ & $<1.00$ & $<1.0$ & 10 & $<1.00$ & 39.2 \\
\hline 372649101344701 & 5 & $<1.00$ & $<1.0$ & 39.7 & $<1.00$ & $<1.00$ & $<1.0$ & $<1.00$ & $<1.0$ & 30 & $<1.00$ & $<1.0$ \\
\hline 372956099512201 & 4 & $<1.00$ & 2.5 & 109 & $<1.00$ & $<1.00$ & $<1.0$ & $<1.00$ & 1.0 & $<10$ & $<1.00$ & $<1.0$ \\
\hline 373229101193201 & 4 & $<1.00$ & $<1.0$ & 20.6 & $<1.00$ & $<1.00$ & 2.8 & $<1.00$ & 2.0 & $<10$ & $<1.00$ & $<1.0$ \\
\hline 373345101070801 & 5 & $<1.00$ & $<1.0$ & 61.6 & $<1.00$ & $<1.00$ & 1.3 & $<1.00$ & $<1.0$ & $<10$ & $<1.00$ & $<1.0$ \\
\hline 373507102162001 & $<1$ & $<1.00$ & $<1.0$ & 20.0 & $<1.00$ & $<1.00$ & -- & $<1.00$ & $<1.0$ & $<10$ & $<1.00$ & $<1.0$ \\
\hline 373527100312701 & 3 & $<1.00$ & 3.4 & 42.1 & $<1.00$ & $<1.00$ & 1.2 & $<1.00$ & 1.0 & $<10$ & $<1.00$ & $<1.0$ \\
\hline 373559102314901 & $<1$ & $<1.00$ & $<1.0$ & 29.8 & $<1.00$ & $<1.00$ & $<1.0$ & $<1.00$ & $<1.0$ & $<10$ & $<1.00$ & $<1.0$ \\
\hline 373732099291201 & 4 & $<1.00$ & 1.4 & 196 & $<1.00$ & $<1.00$ & 1.4 & $<1.00$ & $<1.0$ & $<10$ & $<1.00$ & $<1.0$ \\
\hline 374535102110301 & $<1$ & $<1.00$ & $<1.0$ & 26.0 & $<1.00$ & $<1.00$ & $<1.0$ & $<1.00$ & $<1.0$ & 40 & $<1.00$ & 85.9 \\
\hline 374650100181901 & 3 & $<1.00$ & 1.5 & 70.4 & $<1.00$ & $<1.00$ & 1.1 & $<1.00$ & $<1.0$ & $<10$ & $<1.00$ & $<1.0$ \\
\hline 375129100532301 & 4 & $<1.00$ & $<1.0$ & 63.1 & $<1.00$ & $<1.00$ & 1.5 & $<1.00$ & $<1.0$ & $<10$ & $<1.00$ & $<1.0$ \\
\hline 375447099245001 & 4 & $<1.00$ & 2.5 & 42.0 & $<1.00$ & $<1.00$ & $<1.0$ & $<1.00$ & 1.8 & $<10$ & $<1.00$ & $<1.0$ \\
\hline 375828101111801 & 3 & $<1.00$ & 2.2 & 19.7 & $<1.00$ & $<1.00$ & $<1.0$ & $<1.00$ & 1.7 & $<10$ & $<1.00$ & $<1.0$ \\
\hline 380331100352801 & 4 & $<1.00$ & 4.1 & 26.2 & $<1.00$ & $<1.00$ & 1.0 & $<1.00$ & 1.8 & $<10$ & $<1.00$ & $<1.0$ \\
\hline 382947100443201 & 2 & $<1.00$ & 6.7 & 20.4 & $<1.00$ & $<1.00$ & $<1.0$ & $<1.00$ & 1.2 & $<10$ & $<1.00$ & $<1.0$ \\
\hline 383008101315601 & 4 & $<1.00$ & 5.3 & 67.5 & $<1.00$ & $<1.00$ & $<1.0$ & $<1.00$ & $<1.0$ & $<10$ & $<1.00$ & $<1.0$ \\
\hline 383758101195801 & 4 & $<1.00$ & 3.5 & 88.1 & $<1.00$ & $<1.00$ & $<1.0$ & $<1.00$ & 1.6 & $<10$ & $<1.00$ & $<1.0$ \\
\hline 383919101040101 & 5 & $<1.00$ & 3.6 & 75.9 & $<1.00$ & $<1.00$ & 1.0 & $<1.00$ & $<1.0$ & $<10$ & $<1.00$ & $<1.0$ \\
\hline 385210100164501 & $<1$ & $<1.00$ & 1.2 & 127 & $<1.00$ & $<1.00$ & -- & $<1.00$ & $<1.0$ & $<10$ & $<1.00$ & $<1.0$ \\
\hline 385904099522201 & 4 & $<1.00$ & 3.4 & 251 & $<1.00$ & $<1.00$ & $<1.0$ & $<1.00$ & 2.8 & $<10$ & $<1.00$ & $<1.0$ \\
\hline 390622101003201 & 5 & $<1.00$ & 2.6 & 52.0 & $<1.00$ & $<1.00$ & 1.2 & $<1.00$ & 1.8 & $<10$ & $<1.00$ & $<1.0$ \\
\hline 390830102052001 & 5 & $<1.00$ & 4.2 & 154 & $<1.00$ & $<1.00$ & $<1.0$ & $<1.00$ & $<1.0$ & $<10$ & $<1.00$ & $<1.0$ \\
\hline 390838100411701 & 5 & $<1.00$ & 4.1 & 151 & $<1.00$ & $<1.00$ & 1.1 & $<1.00$ & 1.8 & $<10$ & $<1.00$ & $<1.0$ \\
\hline 391044100051001 & 4 & $<1.00$ & 5.9 & 298 & $<1.00$ & $<1.00$ & $<1.0$ & $<1.00$ & $<1.0$ & $<10$ & $<1.00$ & $<1.0$ \\
\hline 391921101385501 & 4 & $<1.00$ & 2.0 & 102 & $<1.00$ & $<1.00$ & 1.3 & $<1.00$ & $<1.0$ & $<10$ & 1.18 & $<1.0$ \\
\hline
\end{tabular}




\begin{tabular}{|c|c|c|c|c|c|c|c|c|c|c|c|c|}
\hline STATION NUMBER & $\begin{array}{l}\text { MOLYB- } \\
\text { DENUM, } \\
\text { DIS- } \\
\text { SOLVED } \\
\text { (UG/L } \\
\text { AS MO) }\end{array}$ & $\begin{array}{l}\text { NICKEL, } \\
\text { DIS- } \\
\text { SOLVED } \\
\text { (UG/L } \\
\text { AS NI) }\end{array}$ & $\begin{array}{l}\text { SELE- } \\
\text { NIUM, } \\
\text { DIS- } \\
\text { SOLVED } \\
\text { (UG/L } \\
\text { AS SE) }\end{array}$ & $\begin{array}{l}\text { SILVER, } \\
\text { DIS- } \\
\text { SOLVED } \\
\text { (UG/L } \\
\text { AS AG) }\end{array}$ & $\begin{array}{l}\text { ZINC, } \\
\text { DIS- } \\
\text { SOLVED } \\
\text { (UG/L } \\
\text { AS ZN) }\end{array}$ & $\begin{array}{c}\text { 2, 4-D } \\
\text { METHYL } \\
\text { ESTER, } \\
\text { WATER } \\
\text { FLTRD } \\
\text { REC } \\
\text { (UG/L) }\end{array}$ & $\begin{array}{c}2,4-D, \\
\text { DIS- } \\
\text { SOLVED } \\
\text { (UG/L) }\end{array}$ & $\begin{array}{c}\text { 2, 4-DB } \\
\text { WATER, } \\
\text { FLTRD, } \\
\text { GF } 0.7 \mathrm{U} \\
\text { REC } \\
\text { (UG/L) }\end{array}$ & $\begin{array}{c}2,6 \text {-DI- } \\
\text { ETHYL } \\
\text { ANILINE } \\
\text { WAT FLT } \\
0.7 \text { U } \\
\text { GF, REC } \\
(\mathrm{UG} / \mathrm{L})\end{array}$ & $\begin{array}{c}\text { ACETO- } \\
\text { CHLOR } \\
\text { ESA } \\
\text { FLTRD } \\
0.7 \text { UM } \\
\text { GF REC } \\
\text { (UG/L) }\end{array}$ & $\begin{array}{c}\text { ACETO- } \\
\text { CHLOR } \\
\text { OA } \\
\text { FLTRD } \\
0.7 \text { UM } \\
\text { GE REC } \\
\text { (UG/L) }\end{array}$ & $\begin{array}{l}\text { ACETO- } \\
\text { CHLOR, } \\
\text { WATER } \\
\text { FLTRD } \\
\text { REC } \\
\text { (UG/L) }\end{array}$ \\
\hline $\begin{array}{l}344800101324901 \\
345826100580501 \\
351656101161101 \\
351914101204401 \\
352035100293301\end{array}$ & $\begin{array}{r}4.0 \\
<1.0 \\
4.3 \\
2.7 \\
<1.0\end{array}$ & $\begin{array}{l}<1.00 \\
<1.00 \\
<1.00 \\
<1.00 \\
<1.00\end{array}$ & $\begin{array}{l}5.0 \\
4.0 \\
1.2 \\
3.0 \\
1.3\end{array}$ & $\begin{array}{l}<1.0 \\
<1.0 \\
<1.0 \\
<1.0 \\
<1.0\end{array}$ & $\begin{array}{r}10 \\
12 \\
35 \\
96 \\
3\end{array}$ & $\begin{array}{l}<.086 \\
<.086 \\
<.086 \\
<.086 \\
<.086\end{array}$ & $\begin{array}{l}<.08 \\
<.08 \\
<.08 \\
<.08 \\
<.08\end{array}$ & $\begin{array}{l}<.05 \\
<.05 \\
<.05 \\
<.05 \\
<.05\end{array}$ & $\begin{array}{l}<.003 \\
<.003 \\
<.003 \\
<.003 \\
<.003\end{array}$ & $\begin{array}{l}<.05 \\
<.05 \\
<.05 \\
<.05 \\
<.05\end{array}$ & $\begin{array}{l}<.05 \\
<.05 \\
<.05 \\
<.05 \\
<.05\end{array}$ & $\begin{array}{l}<.002 \\
<.002 \\
<.002 \\
<.002 \\
<.002\end{array}$ \\
\hline $\begin{array}{l}352249100425401 \\
352513101372101 \\
352909101084001 \\
353110100550401 \\
353941102350201\end{array}$ & $\begin{array}{r}<1.0 \\
5.4 \\
10.8 \\
2.8 \\
5.1\end{array}$ & $\begin{array}{l}<1.00 \\
<1.00 \\
<1.00 \\
<1.00 \\
<1.00\end{array}$ & $\begin{array}{r}1.1 \\
<1.0 \\
1.7 \\
2.6 \\
2.9\end{array}$ & $\begin{array}{l}<1.0 \\
<1.0 \\
<1.0 \\
<1.0 \\
<1.0\end{array}$ & $\begin{array}{r}4 \\
135 \\
1 \\
136 \\
49\end{array}$ & $\begin{array}{l}<.086 \\
<.086 \\
<.086 \\
<.086 \\
<.086\end{array}$ & $\begin{array}{l}<.08 \\
<.08 \\
<.08 \\
<.08 \\
<.08\end{array}$ & $\begin{array}{l}<.05 \\
<.05 \\
<.05 \\
<.05 \\
<.05\end{array}$ & $\begin{array}{l}<.003 \\
<.003 \\
<.003 \\
<.003 \\
<.003\end{array}$ & $\begin{array}{l}<.05 \\
<.05 \\
<.05 \\
<.05 \\
<.05\end{array}$ & $\begin{array}{l}<.05 \\
<.05 \\
<.05 \\
<.05 \\
<.05\end{array}$ & $\begin{array}{l}<.002 \\
<.002 \\
<.002 \\
<.002 \\
<.002\end{array}$ \\
\hline $\begin{array}{l}354248100501501 \\
354331102183601 \\
354348102543601 \\
354656099480301 \\
354728102295901\end{array}$ & $\begin{array}{r}3.4 \\
6.5 \\
<1.0 \\
1.3 \\
5.8\end{array}$ & $\begin{array}{r}<1.00 \\
<1.00 \\
<1.00 \\
1.12 \\
<1.00\end{array}$ & $\begin{array}{r}<1.0 \\
1.7 \\
1.7 \\
<1.0 \\
3.9\end{array}$ & $\begin{array}{l}<1.0 \\
<1.0 \\
<1.0 \\
<1.0 \\
<1.0\end{array}$ & $\begin{array}{r}28 \\
60 \\
8 \\
12 \\
12\end{array}$ & $\begin{array}{l}<.086 \\
<.086 \\
<.086 \\
<.086 \\
<.086\end{array}$ & $\begin{array}{l}<.08 \\
<.08 \\
<.08 \\
<.08 \\
<.08\end{array}$ & $\begin{array}{l}<.05 \\
<.05 \\
<.05 \\
<.05 \\
<.05\end{array}$ & $\begin{array}{l}<.003 \\
<.003 \\
<.003 \\
<.003 \\
<.003\end{array}$ & $\begin{array}{l}<.05 \\
<.05 \\
<.05 \\
<.05 \\
<.05\end{array}$ & $\begin{array}{l}<.05 \\
<.05 \\
<.05 \\
<.05 \\
<.05\end{array}$ & $\begin{array}{l}<.002 \\
<.002 \\
<.002 \\
<.002 \\
<.002\end{array}$ \\
\hline $\begin{array}{l}354918102020901 \\
355701100313001 \\
355852101274101 \\
355916103215201 \\
360703102361901\end{array}$ & $\begin{array}{l}6.3 \\
1.7 \\
8.1 \\
3.8 \\
4.5\end{array}$ & $\begin{array}{r}<1.00 \\
1.06 \\
<1.00 \\
1.98 \\
<1.00\end{array}$ & $\begin{array}{r}2.2 \\
<1.0 \\
2.3 \\
9.7 \\
3.3\end{array}$ & $\begin{array}{l}<1.0 \\
<1.0 \\
<1.0 \\
<1.0 \\
<1.0\end{array}$ & $\begin{array}{r}76 \\
6 \\
12 \\
3 \\
52\end{array}$ & $\begin{array}{l}<.086 \\
<.086 \\
<.086 \\
<.086 \\
<.086\end{array}$ & $\begin{array}{l}<.08 \\
<.08 \\
<.08 \\
<.08 \\
<.08\end{array}$ & $\begin{array}{l}<.05 \\
<.05 \\
<.05 \\
<.05 \\
<.05\end{array}$ & $\begin{array}{l}<.003 \\
<.003 \\
<.003 \\
<.003 \\
<.003\end{array}$ & $\begin{array}{l}<.05 \\
<.05 \\
<.05 \\
<.05 \\
<.05\end{array}$ & $\begin{array}{l}<.05 \\
<.05 \\
<.05 \\
<.05 \\
<.05\end{array}$ & $\begin{array}{l}<.002 \\
<.002 \\
<.002 \\
<.002 \\
<.002\end{array}$ \\
\hline $\begin{array}{l}360838102560301 \\
360944100162101 \\
361014100221001 \\
361049100564901 \\
361054101393601\end{array}$ & $\begin{array}{l}3.9 \\
2.1 \\
1.1 \\
4.9 \\
9.3\end{array}$ & $\begin{array}{r}<1.00 \\
<1.00 \\
1.29 \\
<1.00 \\
<1.00\end{array}$ & $\begin{array}{l}2.0 \\
1.2 \\
3.3 \\
2.7 \\
6.9\end{array}$ & $\begin{array}{l}<1.0 \\
<1.0 \\
<1.0 \\
<1.0 \\
<1.0\end{array}$ & $\begin{array}{r}3 \\
1 \\
36 \\
119 \\
63\end{array}$ & $\begin{array}{l}<.086 \\
<.086 \\
<.086 \\
<.086 \\
<.086\end{array}$ & $\begin{array}{l}<.08 \\
<.08 \\
<.08 \\
<.08 \\
<.08\end{array}$ & $\begin{array}{l}<.05 \\
<.05 \\
<.05 \\
<.05 \\
<.05\end{array}$ & $\begin{array}{l}<.003 \\
<.003 \\
<.003 \\
<.003 \\
<.003\end{array}$ & $\begin{array}{l}<.05 \\
<.05 \\
<.05 \\
<.05 \\
<.05\end{array}$ & $\begin{array}{l}<.05 \\
<.05 \\
<.05 \\
<.05 \\
<.05\end{array}$ & $\begin{array}{l}<.002 \\
<.002 \\
<.002 \\
<.002 \\
<.002\end{array}$ \\
\hline $\begin{array}{l}361114099420501 \\
361517102065301 \\
362115101173901 \\
362134102035101 \\
362615100435801\end{array}$ & $\begin{array}{r}<1.0 \\
8.2 \\
9.1 \\
15.4 \\
6.0\end{array}$ & $\begin{array}{r}1.99 \\
<1.00 \\
2.27 \\
<1.00 \\
<1.00\end{array}$ & $\begin{array}{r}<1.0 \\
3.2 \\
4.8 \\
2.0 \\
1.7\end{array}$ & $\begin{array}{l}<1.0 \\
<1.0 \\
<1.0 \\
<1.0 \\
<1.0\end{array}$ & $\begin{array}{l}18 \\
81 \\
93 \\
94 \\
11\end{array}$ & $\begin{array}{l}<.086 \\
<.086 \\
<.086 \\
<.086 \\
<.086\end{array}$ & $\begin{array}{l}<.08 \\
<.08 \\
<.08 \\
<.08 \\
<.08\end{array}$ & $\begin{array}{l}<.05 \\
<.05 \\
<.05 \\
<.05 \\
<.05\end{array}$ & $\begin{array}{l}<.003 \\
<.003 \\
<.003 \\
<.003 \\
<.003\end{array}$ & $\begin{array}{l}<.05 \\
<.05 \\
-- \\
<.05 \\
<.05\end{array}$ & $\begin{array}{l}<.05 \\
<.05 \\
-- \\
<.05 \\
<.05\end{array}$ & $\begin{array}{l}<.002 \\
<.002 \\
<.002 \\
<.002 \\
<.002\end{array}$ \\
\hline $\begin{array}{l}362744102334901 \\
363057101384701 \\
363104100035501 \\
363154099310401 \\
363157102565601\end{array}$ & $\begin{array}{r}21.9 \\
4.9 \\
1.0 \\
<1.0 \\
3.8\end{array}$ & $\begin{array}{l}<1.00 \\
<1.00 \\
<1.00 \\
<1.00 \\
<1.00\end{array}$ & $\begin{array}{r}1.7 \\
<1.0 \\
1.4 \\
<1.0 \\
2.8\end{array}$ & $\begin{array}{l}<1.0 \\
<1.0 \\
<1.0 \\
<1.0 \\
<1.0\end{array}$ & $\begin{array}{r}18 \\
51 \\
11 \\
1 \\
2\end{array}$ & $\begin{array}{l}<.086 \\
<.086 \\
<.086 \\
<.086 \\
<.086\end{array}$ & $\begin{array}{l}<.08 \\
<.08 \\
<.08 \\
<.08 \\
<.08\end{array}$ & $\begin{array}{l}<.05 \\
<.05 \\
<.05 \\
<.05 \\
<.05\end{array}$ & $\begin{array}{l}<.003 \\
<.003 \\
<.003 \\
<.003 \\
<.003\end{array}$ & $\begin{array}{l}<.05 \\
<.05 \\
<.05 \\
<.05 \\
<.05\end{array}$ & $\begin{array}{l}<.05 \\
<.05 \\
<.05 \\
<.05 \\
<.05\end{array}$ & $\begin{array}{l}<.002 \\
<.002 \\
<.002 \\
<.002 \\
<.002\end{array}$ \\
\hline $\begin{array}{l}363239100301801 \\
363427102440401 \\
364219101394101 \\
364411102321201 \\
365223102113001\end{array}$ & $\begin{array}{r}9.0 \\
6.7 \\
8.7 \\
3.4 \\
11.1\end{array}$ & $\begin{array}{r}<1.00 \\
2.31 \\
<1.00 \\
<1.00 \\
1.04\end{array}$ & $\begin{array}{r}<1.0 \\
3.3 \\
<1.0 \\
4.0 \\
4.1\end{array}$ & $\begin{array}{l}<1.0 \\
<1.0 \\
<1.0 \\
<1.0 \\
<1.0\end{array}$ & $\begin{array}{r}28 \\
5 \\
8 \\
6 \\
8\end{array}$ & $\begin{array}{l}<.086 \\
<.086 \\
<.086 \\
<.086 \\
<.086\end{array}$ & $\begin{array}{l}<.08 \\
<.08 \\
<.08 \\
<.08 \\
<.08\end{array}$ & $\begin{array}{l}<.05 \\
<.05 \\
<.05 \\
<.05 \\
<.05\end{array}$ & $\begin{array}{l}<.003 \\
<.003 \\
<.003 \\
<.003 \\
<.003\end{array}$ & $\begin{array}{l}<.05 \\
<.05 \\
<.05 \\
<.05 \\
<.05\end{array}$ & $\begin{array}{l}<.05 \\
<.05 \\
<.05 \\
<.05 \\
<.05\end{array}$ & $\begin{array}{l}<.002 \\
<.002 \\
<.002 \\
<.002 \\
<.002\end{array}$ \\
\hline $\begin{array}{l}365422101083701 \\
365445100381901 \\
365821101375301 \\
365934101573001 \\
370358100510301\end{array}$ & $\begin{array}{l}2.7 \\
5.1 \\
4.7 \\
4.2 \\
3.4\end{array}$ & $\begin{array}{r}<1.00 \\
1.33 \\
<1.00 \\
2.18 \\
<1.00\end{array}$ & $\begin{array}{l}4.5 \\
5.8 \\
1.8 \\
1.3 \\
4.4\end{array}$ & $\begin{array}{l}<1.0 \\
<1.0 \\
<1.0 \\
<1.0 \\
<1.0\end{array}$ & $\begin{array}{r}31 \\
10 \\
169 \\
78 \\
33\end{array}$ & $\begin{array}{l}<.086 \\
<.086 \\
<.086 \\
<.086 \\
<.086\end{array}$ & $\begin{array}{l}<.08 \\
<.08 \\
<.08 \\
<.08 \\
<.08\end{array}$ & $\begin{array}{l}<.05 \\
<.05 \\
<.05 \\
<.05 \\
<.05\end{array}$ & $\begin{array}{l}<.003 \\
<.003 \\
<.003 \\
<.003 \\
<.003\end{array}$ & $\begin{array}{l}<.05 \\
<.05 \\
<.05 \\
<.05 \\
<.05\end{array}$ & $\begin{array}{l}<.05 \\
<.05 \\
<.05 \\
<.05 \\
<.05\end{array}$ & $\begin{array}{l}<.002 \\
<.002 \\
<.002 \\
<.002 \\
<.002\end{array}$ \\
\hline $\begin{array}{l}370458101514401 \\
370724100281601 \\
371738101220301 \\
372534100443501 \\
372649101344701\end{array}$ & $\begin{array}{r}1.9 \\
5.9 \\
3.3 \\
25.5 \\
11.1\end{array}$ & $\begin{array}{r}2.20 \\
1.93 \\
<1.00 \\
1.69 \\
1.22\end{array}$ & $\begin{array}{l}5.1 \\
6.1 \\
3.8 \\
3.4 \\
2.6\end{array}$ & $\begin{array}{l}<1.0 \\
<1.0 \\
<1.0 \\
<1.0 \\
<1.0\end{array}$ & $\begin{array}{r}7 \\
2 \\
15 \\
14 \\
154\end{array}$ & $\begin{array}{l}<.086 \\
<.086 \\
<.086 \\
<.086 \\
<.086\end{array}$ & $\begin{array}{l}<.08 \\
<.08 \\
<.08 \\
<.08 \\
<.08\end{array}$ & $\begin{array}{l}<.05 \\
<.05 \\
<.05 \\
<.05 \\
<.05\end{array}$ & $\begin{array}{l}<.003 \\
<.003 \\
<.003 \\
<.003 \\
<.003\end{array}$ & $\begin{array}{l}<.05 \\
<.05 \\
<.05 \\
<.05 \\
<.05\end{array}$ & $\begin{array}{l}<.05 \\
<.05 \\
<.05 \\
<.05 \\
<.05\end{array}$ & $\begin{array}{l}<.002 \\
<.002 \\
<.002 \\
<.002 \\
<.002\end{array}$ \\
\hline $\begin{array}{l}372956099512201 \\
373229101193201 \\
373345101070801 \\
373507102162001 \\
373527100312701\end{array}$ & $\begin{array}{r}4.9 \\
13.3 \\
11.4 \\
6.9 \\
8.9\end{array}$ & $\begin{array}{r}<1.00 \\
1.02 \\
1.51 \\
<1.00 \\
<1.00\end{array}$ & $\begin{array}{l}2.5 \\
9.6 \\
6.3 \\
4.2 \\
2.9\end{array}$ & $\begin{array}{l}<1.0 \\
<1.0 \\
<1.0 \\
<1.0 \\
<1.0\end{array}$ & $\begin{array}{r}8 \\
2 \\
23 \\
<1 \\
<1\end{array}$ & $\begin{array}{l}<.086 \\
<.086 \\
<.086 \\
<.086 \\
<.086\end{array}$ & $\begin{array}{l}<.08 \\
<.08 \\
<.08 \\
<.08 \\
<.08\end{array}$ & $\begin{array}{l}<.05 \\
<.05 \\
<.05 \\
<.05 \\
<.05\end{array}$ & $\begin{array}{l}<.003 \\
<.003 \\
<.003 \\
<.003 \\
<.003\end{array}$ & $\begin{array}{l}<.05 \\
<.05 \\
<.05 \\
<.05 \\
<.05\end{array}$ & $\begin{array}{l}<.05 \\
<.05 \\
<.05 \\
<.05 \\
<.05\end{array}$ & $\begin{array}{l}<.002 \\
<.002 \\
<.002 \\
<.002 \\
<.002\end{array}$ \\
\hline $\begin{array}{l}373559102314901 \\
373732099291201 \\
374535102110301 \\
374650100181901 \\
375129100532301\end{array}$ & $\begin{array}{r}13.5 \\
2.0 \\
9.8 \\
4.4 \\
4.4\end{array}$ & $\begin{array}{r}<1.00 \\
1.15 \\
<1.00 \\
1.03 \\
1.29\end{array}$ & $\begin{array}{l}3.7 \\
1.4 \\
4.4 \\
2.5 \\
2.5\end{array}$ & $\begin{array}{l}<1.0 \\
<1.0 \\
<1.0 \\
<1.0 \\
<1.0\end{array}$ & $\begin{array}{r}<1 \\
7 \\
77 \\
27 \\
11\end{array}$ & $\begin{array}{l}<.086 \\
<.086 \\
<.086 \\
<.086 \\
<.086\end{array}$ & $\begin{array}{l}<.08 \\
<.08 \\
<.08 \\
<.08 \\
<.08\end{array}$ & $\begin{array}{l}<.05 \\
<.05 \\
<.05 \\
<.05 \\
<.05\end{array}$ & $\begin{array}{l}<.003 \\
<.003 \\
<.003 \\
<.003 \\
<.003\end{array}$ & $\begin{array}{l}<.05 \\
<.05 \\
<.05 \\
<.05 \\
<.05\end{array}$ & $\begin{array}{l}<.05 \\
<.05 \\
<.05 \\
<.05 \\
<.05\end{array}$ & $\begin{array}{l}<.002 \\
<.002 \\
<.002 \\
<.002 \\
<.002\end{array}$ \\
\hline $\begin{array}{l}375447099245001 \\
375828101111801 \\
380331100352801 \\
382947100443201 \\
383008101315601\end{array}$ & $\begin{array}{r}2.7 \\
5.1 \\
4.7 \\
51.7 \\
9.2\end{array}$ & $\begin{array}{r}2.73 \\
1.22 \\
1.13 \\
1.06 \\
<1.00\end{array}$ & $\begin{array}{r}6.7 \\
4.8 \\
17.8 \\
8.0 \\
3.7\end{array}$ & $\begin{array}{l}<1.0 \\
<1.0 \\
<1.0 \\
<1.0 \\
<1.0\end{array}$ & $\begin{array}{r}1 \\
2 \\
6 \\
38 \\
24\end{array}$ & $\begin{array}{l}<.086 \\
<.086 \\
<.086 \\
<.086 \\
<.086\end{array}$ & $\begin{array}{l}<.08 \\
<.08 \\
<.08 \\
<.08 \\
<.08\end{array}$ & $\begin{array}{l}<.05 \\
<.05 \\
<.05 \\
<.05 \\
<.05\end{array}$ & $\begin{array}{l}<.003 \\
<.003 \\
<.003 \\
<.003 \\
<.003\end{array}$ & $\begin{array}{l}<.05 \\
<.05 \\
<.05 \\
<.05 \\
<.05\end{array}$ & $\begin{array}{l}<.05 \\
<.05 \\
<.05 \\
<.05 \\
<.05\end{array}$ & $\begin{array}{l}<.002 \\
<.002 \\
<.002 \\
<.002 \\
<.002\end{array}$ \\
\hline $\begin{array}{l}383758101195801 \\
383919101040101 \\
385210100164501 \\
385904099522201 \\
390622101003201\end{array}$ & $\begin{array}{r}12.9 \\
11.4 \\
<1.0 \\
1.6 \\
7.1\end{array}$ & $\begin{array}{r}1.46 \\
1.06 \\
<1.00 \\
2.23 \\
<1.00\end{array}$ & $\begin{array}{r}11.5 \\
6.5 \\
3.1 \\
3.5 \\
6.1\end{array}$ & $\begin{array}{l}<1.0 \\
<1.0 \\
<1.0 \\
<1.0 \\
<1.0\end{array}$ & $\begin{array}{r}50 \\
15 \\
1 \\
3 \\
53\end{array}$ & $\begin{array}{l}<.086 \\
<.086 \\
<.086 \\
<.086 \\
<.086\end{array}$ & $\begin{array}{l}<.08 \\
<.08 \\
<.08 \\
<.08 \\
<.08\end{array}$ & $\begin{array}{l}<.05 \\
<.05 \\
<.05 \\
<.05 \\
<.05\end{array}$ & $\begin{array}{l}<.003 \\
<.003 \\
<.003 \\
<.003 \\
<.003\end{array}$ & $\begin{array}{l}<.05 \\
<.05 \\
<.05 \\
<.05 \\
<.05\end{array}$ & $\begin{array}{l}<.05 \\
<.05 \\
<.05 \\
<.05 \\
<.05\end{array}$ & $\begin{array}{l}<.002 \\
<.002 \\
<.002 \\
<.002 \\
<.002\end{array}$ \\
\hline
\end{tabular}




\begin{tabular}{|c|c|c|c|c|c|c|c|c|c|c|c|c|}
\hline STATION & $\begin{array}{c}\text { ALA- } \\
\text { CHLOR } \\
\text { OA } \\
\text { FLTRD } \\
0.7 \text { UM } \\
\text { GF REC } \\
(\text { UG/L) }\end{array}$ & $\begin{array}{c}\text { ALA- } \\
\text { CHLOR, } \\
\text { (ESA) } \\
\text { WAT FLT } \\
\text { GF } 0.7 \mathrm{U} \\
\text { REC } \\
\text { (UG/L) }\end{array}$ & $\begin{array}{l}\text { ALA- } \\
\text { CHLOR, } \\
\text { WATER, } \\
\text { DISS, } \\
\text { REC, } \\
\text { (UG/L) }\end{array}$ & $\begin{array}{c}\text { ALDI- } \\
\text { CARB } \\
\text { SULFONE } \\
\text { WAT, FLT } \\
\text { GF } 0.7 \mathrm{U} \\
\text { REC } \\
\text { (UG/L) }\end{array}$ & $\begin{array}{c}\text { ALDICA- } \\
\text { RB SUL- } \\
\text { FOXIDE, } \\
\text { WAT, FLT } \\
\text { GF } 0.7 \mathrm{U} \\
\text { REC } \\
\text { (UG/L) }\end{array}$ & $\begin{array}{c}\text { ALDI- } \\
\text { CARB, } \\
\text { WATER, } \\
\text { FLTRD, } \\
\text { GF } 0.7 U \\
\text { REC } \\
\text { (UG/L) }\end{array}$ & $\begin{array}{c}\text { ALPHA } \\
\text { BHC } \\
\text { DIS- } \\
\text { SOLVED } \\
\text { (UG/L) }\end{array}$ & $\begin{array}{l}\text { ATRA- } \\
\text { ZINE, } \\
\text { WATER, } \\
\text { DISS, } \\
\text { REC } \\
\text { (UG/L) }\end{array}$ & $\begin{array}{c}\text { BENDIO- } \\
\text { CARB, } \\
\text { WATER } \\
\text { FLTRD } \\
\text { REC } \\
\text { (UG/L) }\end{array}$ & $\begin{array}{l}\text { BEN- } \\
\text { FLUR- } \\
\text { ALIN } \\
\text { WAT FLD } \\
0.7 \text { U } \\
\text { GF, REC } \\
\text { (UG/L) }\end{array}$ & $\begin{array}{c}\text { BEN- } \\
\text { SUL- } \\
\text { FURON } \\
\text { METHYL } \\
\text { WAT FLT } \\
\text { REC } \\
\text { (UG/L) }\end{array}$ & $\begin{array}{c}\text { BENTA- } \\
\text { ZON, } \\
\text { WATER, } \\
\text { FLTRD, } \\
\text { GF } 0.7 \mathrm{U} \\
\text { REC } \\
\text { (UG/L) }\end{array}$ \\
\hline $\begin{array}{l}344800101324901 \\
345826100580501 \\
351656101161101 \\
351914101204401 \\
352035100293301\end{array}$ & $\begin{array}{l}<.05 \\
<.05 \\
<.05 \\
<.05 \\
<.05\end{array}$ & $\begin{array}{l}<.050 \\
<.050 \\
<.050 \\
<.050 \\
<.050\end{array}$ & $\begin{array}{l}<.002 \\
<.002 \\
<.002 \\
<.002 \\
<.002\end{array}$ & $\begin{array}{l}<.16 \\
<.16 \\
<.16 \\
<.16 \\
<.16\end{array}$ & $\begin{array}{l}<.03 \\
<.03 \\
<.03 \\
<.03 \\
<.03\end{array}$ & $\begin{array}{l}<.08 \\
<.08 \\
<.08 \\
<.08 \\
<.08\end{array}$ & $\begin{array}{l}<.002 \\
<.002 \\
<.002 \\
<.002 \\
<.002\end{array}$ & $\begin{array}{l}<.001 \\
<.001 \\
<.001 \\
<.001 \\
.005\end{array}$ & $\begin{array}{l}<.061 \\
<.061 \\
<.061 \\
<.061 \\
<.061\end{array}$ & $\begin{array}{l}<.002 \\
<.002 \\
<.002 \\
<.002 \\
<.002\end{array}$ & $\begin{array}{l}<.0482 \\
<.0482 \\
<.0482 \\
<.0482 \\
<.0482\end{array}$ & $\begin{array}{l}<.02 \\
<.02 \\
<.02 \\
<.02 \\
<.02\end{array}$ \\
\hline $\begin{array}{l}352249100425401 \\
352513101372101 \\
352909101084001 \\
353110100550401 \\
353941102350201\end{array}$ & $\begin{array}{l}<.05 \\
<.05 \\
<.05 \\
<.05 \\
<.05\end{array}$ & $\begin{array}{l}<.050 \\
<.050 \\
<.050 \\
<.050 \\
<.050\end{array}$ & $\begin{array}{l}<.002 \\
<.002 \\
<.002 \\
<.002 \\
<.002\end{array}$ & $\begin{array}{l}<.16 \\
<.16 \\
<.16 \\
<.16 \\
<.16\end{array}$ & $\begin{array}{l}<.03 \\
<.03 \\
<.03 \\
<.03 \\
<.03\end{array}$ & $\begin{array}{l}<.08 \\
<.08 \\
<.08 \\
<.08 \\
<.08\end{array}$ & $\begin{array}{l}<.002 \\
<.002 \\
<.002 \\
<.002 \\
<.002\end{array}$ & $\begin{array}{l}<.001 \\
<.001 \\
<.001 \\
<.001 \\
<.001\end{array}$ & $\begin{array}{l}<.061 \\
<.061 \\
<.061 \\
<.061 \\
<.061\end{array}$ & $\begin{array}{l}<.002 \\
<.002 \\
<.002 \\
<.002 \\
<.002\end{array}$ & $\begin{array}{l}<.0482 \\
<.0482 \\
<.0482 \\
<.0482 \\
<.0482\end{array}$ & $\begin{array}{l}<.02 \\
<.02 \\
<.02 \\
<.02 \\
<.02\end{array}$ \\
\hline $\begin{array}{l}354248100501501 \\
354331102183601 \\
354348102543601 \\
354656099480301 \\
354728102295901\end{array}$ & $\begin{array}{l}<.05 \\
<.05 \\
<.05 \\
<.05 \\
<.05\end{array}$ & $\begin{array}{l}<.050 \\
<.050 \\
<.050 \\
<.050 \\
<.050\end{array}$ & $\begin{array}{l}<.002 \\
<.002 \\
<.002 \\
<.002 \\
<.002\end{array}$ & $\begin{array}{l}<.16 \\
<.16 \\
<.16 \\
<.16 \\
<.16\end{array}$ & $\begin{array}{l}<.03 \\
<.03 \\
<.03 \\
<.03 \\
<.03\end{array}$ & $\begin{array}{l}<.08 \\
<.08 \\
<.08 \\
<.08 \\
<.08\end{array}$ & $\begin{array}{l}<.002 \\
<.002 \\
<.002 \\
<.002 \\
<.002\end{array}$ & $\begin{array}{l}<.001 \\
<.001 \\
<.001 \\
<.001 \\
<.001\end{array}$ & $\begin{array}{l}<.061 \\
<.061 \\
<.061 \\
<.061 \\
<.061\end{array}$ & $\begin{array}{l}<.002 \\
<.002 \\
<.002 \\
<.002 \\
<.002\end{array}$ & $\begin{array}{l}<.0482 \\
<.0482 \\
<.0482 \\
<.0482 \\
<.0482\end{array}$ & $\begin{array}{l}<.02 \\
<.02 \\
<.02 \\
<.02 \\
<.02\end{array}$ \\
\hline $\begin{array}{l}354918102020901 \\
355701100313001 \\
355852101274101 \\
355916103215201 \\
360703102361901\end{array}$ & $\begin{array}{l}<.05 \\
<.05 \\
<.05 \\
<.05 \\
<.05\end{array}$ & $\begin{array}{l}<.050 \\
<.050 \\
<.050 \\
<.050 \\
<.050\end{array}$ & $\begin{array}{l}<.002 \\
<.002 \\
<.002 \\
<.002 \\
<.002\end{array}$ & $\begin{array}{l}<.16 \\
<.16 \\
<.16 \\
<.16 \\
<.16\end{array}$ & $\begin{array}{l}<.03 \\
<.03 \\
<.03 \\
<.03 \\
<.03\end{array}$ & $\begin{array}{l}<.08 \\
<.08 \\
<.08 \\
<.08 \\
<.08\end{array}$ & $\begin{array}{l}<.002 \\
<.002 \\
<.002 \\
<.002 \\
<.002\end{array}$ & $\begin{array}{l}.019 \\
<.001 \\
<.001 \\
<.001 \\
<.001\end{array}$ & $\begin{array}{l}<.061 \\
<.061 \\
<.061 \\
<.061 \\
<.061\end{array}$ & $\begin{array}{l}<.002 \\
<.002 \\
<.002 \\
<.002 \\
<.002\end{array}$ & $\begin{array}{l}<.0482 \\
<.0482 \\
<.0482 \\
<.0482 \\
<.0482\end{array}$ & $\begin{array}{l}<.02 \\
<.02 \\
<.02 \\
<.02 \\
<.02\end{array}$ \\
\hline $\begin{array}{l}360838102560301 \\
360944100162101 \\
361014100221001 \\
361049100564901 \\
361054101393601\end{array}$ & $\begin{array}{l}<.05 \\
<.05 \\
<.05 \\
<.05 \\
<.05\end{array}$ & $\begin{array}{l}<.050 \\
<.050 \\
<.050 \\
<.050 \\
<.050\end{array}$ & $\begin{array}{l}<.002 \\
<.002 \\
<.002 \\
<.002 \\
<.002\end{array}$ & $\begin{array}{l}<.16 \\
<.16 \\
<.16 \\
<.16 \\
<.16\end{array}$ & $\begin{array}{l}<.03 \\
<.03 \\
<.03 \\
<.03 \\
<.03\end{array}$ & $\begin{array}{l}<.08 \\
<.08 \\
<.08 \\
<.08 \\
<.08\end{array}$ & $\begin{array}{l}<.002 \\
<.002 \\
<.002 \\
<.002 \\
<.002\end{array}$ & $\begin{array}{l}<.001 \\
<.001 \\
<.001 \\
<.001 \\
<.001\end{array}$ & $\begin{array}{l}<.061 \\
<.061 \\
<.061 \\
<.061 \\
<.061\end{array}$ & $\begin{array}{l}<.002 \\
<.002 \\
<.002 \\
<.002 \\
<.002\end{array}$ & $\begin{array}{l}<.0482 \\
<.0482 \\
<.0482 \\
<.0482 \\
<.0482\end{array}$ & $\begin{array}{l}<.02 \\
<.02 \\
<.02 \\
<.02 \\
<.02\end{array}$ \\
\hline $\begin{array}{l}361114099420501 \\
361517102065301 \\
362115101173901 \\
362134102035101 \\
362615100435801\end{array}$ & $\begin{array}{l}<.05 \\
<.05 \\
-- \\
<.05 \\
<.05\end{array}$ & $\begin{array}{l}<.050 \\
<.050 \\
-- \\
<.050 \\
<.050\end{array}$ & $\begin{array}{l}<.002 \\
<.002 \\
<.002 \\
<.002 \\
<.002\end{array}$ & $\begin{array}{l}<.16 \\
<.16 \\
<.16 \\
<.16 \\
<.16\end{array}$ & $\begin{array}{l}<.03 \\
<.03 \\
<.03 \\
<.03 \\
<.03\end{array}$ & $\begin{array}{l}<.08 \\
<.08 \\
<.08 \\
<.08 \\
<.08\end{array}$ & $\begin{array}{l}<.002 \\
<.002 \\
<.002 \\
<.002 \\
<.002\end{array}$ & $\begin{array}{l}<.001 \\
<.001 \\
1.06 \\
<.001 \\
<.001\end{array}$ & $\begin{array}{l}<.061 \\
<.061 \\
<.061 \\
<.061 \\
<.061\end{array}$ & $\begin{array}{l}<.002 \\
<.002 \\
<.002 \\
<.002 \\
<.002\end{array}$ & $\begin{array}{l}<.0482 \\
<.0482 \\
<.0482 \\
<.0482 \\
<.0482\end{array}$ & $\begin{array}{l}<.02 \\
<.02 \\
<.02 \\
<.02 \\
<.02\end{array}$ \\
\hline $\begin{array}{l}362744102334901 \\
363057101384701 \\
363104100035501 \\
363154099310401 \\
363157102565601\end{array}$ & $\begin{array}{l}<.05 \\
<.05 \\
<.05 \\
<.05 \\
<.05\end{array}$ & $\begin{array}{l}<.050 \\
<.050 \\
<.050 \\
<.050 \\
<.050\end{array}$ & $\begin{array}{l}<.002 \\
<.002 \\
<.002 \\
<.002 \\
<.002\end{array}$ & $\begin{array}{l}<.16 \\
<.16 \\
<.16 \\
<.16 \\
<.16\end{array}$ & $\begin{array}{l}<.03 \\
<.03 \\
<.03 \\
<.03 \\
<.03\end{array}$ & $\begin{array}{l}<.08 \\
<.08 \\
<.08 \\
<.08 \\
<.08\end{array}$ & $\begin{array}{l}<.002 \\
<.002 \\
<.002 \\
<.002 \\
<.002\end{array}$ & $\begin{array}{l}<.001 \\
<.001 \\
<.001 \\
<.001 \\
<.001\end{array}$ & $\begin{array}{l}<.061 \\
<.061 \\
<.061 \\
<.061 \\
<.061\end{array}$ & $\begin{array}{l}<.002 \\
<.002 \\
<.002 \\
<.002 \\
<.002\end{array}$ & $\begin{array}{l}<.0482 \\
<.0482 \\
<.0482 \\
<.0482 \\
<.0482\end{array}$ & $\begin{array}{l}<.02 \\
<.02 \\
<.02 \\
<.02 \\
<.02\end{array}$ \\
\hline $\begin{array}{l}363239100301801 \\
363427102440401 \\
364219101394101 \\
364411102321201 \\
365223102113001\end{array}$ & $\begin{array}{l}<.05 \\
<.05 \\
<.05 \\
<.05 \\
<.05\end{array}$ & $\begin{array}{l}<.050 \\
<.050 \\
<.050 \\
<.050 \\
<.050\end{array}$ & $\begin{array}{l}<.002 \\
<.002 \\
<.002 \\
<.002 \\
<.002\end{array}$ & $\begin{array}{l}<.16 \\
<.16 \\
<.16 \\
<.16 \\
<.16\end{array}$ & $\begin{array}{l}<.03 \\
<.03 \\
<.03 \\
<.03 \\
<.03\end{array}$ & $\begin{array}{l}<.08 \\
<.08 \\
<.08 \\
<.08 \\
<.08\end{array}$ & $\begin{array}{l}<.002 \\
<.002 \\
<.002 \\
<.002 \\
<.002\end{array}$ & $\begin{array}{l}\quad .014 \\
<.001 \\
<.001 \\
<.001 \\
<.001\end{array}$ & $\begin{array}{l}<.061 \\
<.061 \\
<.061 \\
<.061 \\
<.061\end{array}$ & $\begin{array}{l}<.002 \\
<.002 \\
<.002 \\
<.002 \\
<.002\end{array}$ & $\begin{array}{l}<.0482 \\
<.0482 \\
<.0482 \\
<.0482 \\
<.0482\end{array}$ & $\begin{array}{l}<.02 \\
<.02 \\
<.02 \\
<.02 \\
<.02\end{array}$ \\
\hline $\begin{array}{l}365422101083701 \\
365445100381901 \\
365821101375301 \\
365934101573001 \\
370358100510301\end{array}$ & $\begin{array}{l}<.05 \\
<.05 \\
<.05 \\
<.05 \\
<.05\end{array}$ & $\begin{array}{l}<.050 \\
<.050 \\
<.050 \\
<.050 \\
<.050\end{array}$ & $\begin{array}{l}<.002 \\
<.002 \\
<.002 \\
<.002 \\
<.002\end{array}$ & $\begin{array}{l}<.16 \\
<.16 \\
<.16 \\
<.16 \\
<.16\end{array}$ & $\begin{array}{l}<.03 \\
<.03 \\
<.03 \\
<.03 \\
<.03\end{array}$ & $\begin{array}{l}<.08 \\
<.08 \\
<.08 \\
<.08 \\
<.08\end{array}$ & $\begin{array}{l}<.002 \\
<.002 \\
<.002 \\
<.002 \\
<.002\end{array}$ & $\begin{array}{l}<.001 \\
<.001 \\
<.001 \\
<.001 \\
<.001\end{array}$ & $\begin{array}{l}<.061 \\
<.061 \\
<.061 \\
<.061 \\
<.061\end{array}$ & $\begin{array}{l}<.002 \\
<.002 \\
<.002 \\
<.002 \\
<.002\end{array}$ & $\begin{array}{l}<.0482 \\
<.0482 \\
<.0482 \\
<.0482 \\
<.0482\end{array}$ & $\begin{array}{l}<.02 \\
<.02 \\
<.02 \\
<.02 \\
<.02\end{array}$ \\
\hline $\begin{array}{l}370458101514401 \\
370724100281601 \\
371738101220301 \\
372534100443501 \\
372649101344701\end{array}$ & $\begin{array}{l}<.05 \\
<.05 \\
<.05 \\
<.05 \\
<.05\end{array}$ & $\begin{array}{l}<.050 \\
<.050 \\
<.050 \\
<.050 \\
<.050\end{array}$ & $\begin{array}{l}<.002 \\
<.002 \\
<.002 \\
<.002 \\
<.002\end{array}$ & $\begin{array}{l}<.16 \\
<.16 \\
<.16 \\
<.16 \\
<.16\end{array}$ & $\begin{array}{l}<.03 \\
<.03 \\
<.03 \\
<.03 \\
<.03\end{array}$ & $\begin{array}{l}<.08 \\
<.08 \\
<.08 \\
<.08 \\
<.08\end{array}$ & $\begin{array}{l}<.002 \\
<.002 \\
<.002 \\
<.002 \\
<.002\end{array}$ & $\begin{array}{l}<.001 \\
<.001 \\
<.001 \\
.044 \\
<.001\end{array}$ & $\begin{array}{l}<.061 \\
<.061 \\
<.061 \\
<.061 \\
<.061\end{array}$ & $\begin{array}{l}<.002 \\
<.002 \\
<.002 \\
<.002 \\
<.002\end{array}$ & $\begin{array}{l}<.0482 \\
<.0482 \\
<.0482 \\
<.0482 \\
<.0482\end{array}$ & $\begin{array}{l}<.02 \\
<.02 \\
<.02 \\
<.02 \\
<.02\end{array}$ \\
\hline $\begin{array}{l}372956099512201 \\
373229101193201 \\
373345101070801 \\
373507102162001 \\
373527100312701\end{array}$ & $\begin{array}{l}<.05 \\
<.05 \\
<.05 \\
<.05 \\
<.05\end{array}$ & $\begin{array}{l}<.050 \\
<.050 \\
<.050 \\
<.050 \\
<.050\end{array}$ & $\begin{array}{l}<.002 \\
<.002 \\
<.002 \\
<.002 \\
<.002\end{array}$ & $\begin{array}{l}<.16 \\
<.16 \\
<.16 \\
<.16 \\
<.16\end{array}$ & $\begin{array}{l}<.03 \\
<.03 \\
<.03 \\
<.03 \\
<.03\end{array}$ & $\begin{array}{l}<.08 \\
<.08 \\
<.08 \\
<.08 \\
<.08\end{array}$ & $\begin{array}{l}<.002 \\
<.002 \\
<.002 \\
<.002 \\
<.002\end{array}$ & $\begin{array}{l}<.001 \\
<.001 \\
.936 \\
<.001 \\
<.001\end{array}$ & $\begin{array}{l}<.061 \\
<.061 \\
<.061 \\
<.061 \\
<.061\end{array}$ & $\begin{array}{l}<.002 \\
<.002 \\
<.002 \\
<.002 \\
<.002\end{array}$ & $\begin{array}{l}<.0482 \\
<.0482 \\
<.0482 \\
<.0482 \\
<.0482\end{array}$ & $\begin{array}{l}<.02 \\
<.02 \\
<.02 \\
<.02 \\
<.02\end{array}$ \\
\hline $\begin{array}{l}373559102314901 \\
373732099291201 \\
374535102110301 \\
374650100181901 \\
375129100532301\end{array}$ & $\begin{array}{l}<.05 \\
<.05 \\
<.05 \\
<.05 \\
<.05\end{array}$ & $\begin{array}{l}<.050 \\
<.050 \\
<.050 \\
4.83 \\
<.050\end{array}$ & $\begin{array}{l}<.002 \\
<.002 \\
<.002 \\
<.002 \\
<.002\end{array}$ & $\begin{array}{l}<.16 \\
<.16 \\
<.16 \\
<.16 \\
<.16\end{array}$ & $\begin{array}{l}<.03 \\
<.03 \\
<.03 \\
<.03 \\
<.03\end{array}$ & $\begin{array}{l}<.08 \\
<.08 \\
<.08 \\
<.08 \\
<.08\end{array}$ & $\begin{array}{l}<.002 \\
<.002 \\
<.002 \\
<.002 \\
<.002\end{array}$ & $\begin{array}{r}<.001 \\
.005 \\
<.001 \\
.617 \\
<.001\end{array}$ & $\begin{array}{l}<.061 \\
<.061 \\
<.061 \\
<.061 \\
<.061\end{array}$ & $\begin{array}{l}<.002 \\
<.002 \\
<.002 \\
<.002 \\
<.002\end{array}$ & $\begin{array}{l}<.0482 \\
<.0482 \\
<.0482 \\
<.0482 \\
<.0482\end{array}$ & $\begin{array}{l}<.02 \\
<.02 \\
<.02 \\
<.02 \\
<.02\end{array}$ \\
\hline $\begin{array}{l}375447099245001 \\
375828101111801 \\
380331100352801 \\
382947100443201 \\
383008101315601\end{array}$ & $\begin{array}{l}<.05 \\
<.05 \\
<.05 \\
<.05 \\
<.05\end{array}$ & $\begin{array}{l}.150 \\
<.050 \\
<.050 \\
<.050 \\
<.050\end{array}$ & $\begin{array}{l}<.002 \\
<.002 \\
<.002 \\
<.002 \\
<.002\end{array}$ & $\begin{array}{l}<.16 \\
<.16 \\
<.16 \\
<.16 \\
<.16\end{array}$ & $\begin{array}{l}<.03 \\
<.03 \\
<.03 \\
<.03 \\
<.03\end{array}$ & $\begin{array}{l}<.08 \\
<.08 \\
<.08 \\
<.08 \\
<.08\end{array}$ & $\begin{array}{l}<.002 \\
<.002 \\
<.002 \\
<.002 \\
<.002\end{array}$ & $\begin{array}{r}.008 \\
<.001 \\
<.001 \\
<.001 \\
.040\end{array}$ & $\begin{array}{l}<.061 \\
<.061 \\
<.061 \\
<.061 \\
<.061\end{array}$ & $\begin{array}{l}<.002 \\
<.002 \\
<.002 \\
<.002 \\
<.002\end{array}$ & $\begin{array}{l}<.0482 \\
<.0482 \\
<.0482 \\
<.0482 \\
<.0482\end{array}$ & $\begin{array}{l}<.02 \\
<.02 \\
<.02 \\
<.02 \\
<.02\end{array}$ \\
\hline $\begin{array}{l}383758101195801 \\
383919101040101 \\
385210100164501 \\
385904099522201 \\
390622101003201\end{array}$ & $\begin{array}{l}<.05 \\
<.05 \\
<.05 \\
<.05 \\
<.05\end{array}$ & $\begin{array}{l}<.050 \\
<.050 \\
<.050 \\
<.050 \\
<.050\end{array}$ & $\begin{array}{l}<.002 \\
<.002 \\
<.002 \\
<.002 \\
<.002\end{array}$ & $\begin{array}{l}<.16 \\
<.16 \\
<.16 \\
<.16 \\
<.16\end{array}$ & $\begin{array}{l}<.03 \\
<.03 \\
<.03 \\
<.03 \\
<.03\end{array}$ & $\begin{array}{l}<.08 \\
<.08 \\
<.08 \\
<.08 \\
<.08\end{array}$ & $\begin{array}{l}<.002 \\
<.002 \\
<.002 \\
<.002 \\
<.002\end{array}$ & $\begin{array}{r}.102 \\
.017 \\
<.001 \\
1.38 \\
.199\end{array}$ & $\begin{array}{l}<.061 \\
<.061 \\
<.061 \\
<.061 \\
<.061\end{array}$ & $\begin{array}{l}<.002 \\
<.002 \\
<.002 \\
<.002 \\
<.002\end{array}$ & $\begin{array}{l}<.0482 \\
<.0482 \\
<.0482 \\
<.0482 \\
<.0482\end{array}$ & $\begin{array}{l}<.02 \\
<.02 \\
<.02 \\
<.02 \\
<.02\end{array}$ \\
\hline
\end{tabular}


Appendix 1. Water-quality data from 74 domestic water-supply wells completed in the central High Plains aquifer-Continued

\begin{tabular}{|c|c|c|c|c|c|c|c|c|c|c|c|c|}
\hline STATION & $\begin{array}{l}\text { BRO- } \\
\text { MACIL, } \\
\text { WATER, } \\
\text { DISS, } \\
\text { REC } \\
\text { (UG/L) }\end{array}$ & $\begin{array}{c}\text { BRO- } \\
\text { MOXYNIL } \\
\text { WATER, } \\
\text { FLTRD, } \\
\text { GF 0.7U } \\
\text { REC } \\
\text { (UG/L) }\end{array}$ & $\begin{array}{l}\text { BUTYL- } \\
\text { ATE, } \\
\text { WATER, } \\
\text { DISS, } \\
\text { REC } \\
\text { (UG/L) }\end{array}$ & $\begin{array}{c}\text { CAF- } \\
\text { FEINE, } \\
\text { WATER } \\
\text { FLTRD } \\
\text { REC } \\
\text { (UG/L) }\end{array}$ & $\begin{array}{c}\text { CAR- } \\
\text { BARYL, } \\
\text { WATER, } \\
\text { FLTRD, } \\
\text { GF } 0.7 \mathrm{U} \\
\text { REC } \\
\text { (UG/L) }\end{array}$ & $\begin{array}{c}\text { CAR- } \\
\text { BARYL } \\
\text { WATER } \\
\text { FLTRD } \\
0.7 \text { U } \\
\text { GE, REC } \\
\text { (UG/L) }\end{array}$ & $\begin{array}{c}\text { CARBO- } \\
\text { FURAN, } \\
\text { WATER, } \\
\text { FLTRD, } \\
\text { GF } 0.7 \mathrm{U} \\
\text { REC } \\
\text { (UG/L) }\end{array}$ & $\begin{array}{l}\text { CARBO- } \\
\text { FURAN } \\
\text { WATER } \\
\text { FLTRD } \\
0.7 \text { U } \\
\text { GF, REC } \\
\text { (UG/L) }\end{array}$ & $\begin{array}{l}\text { CHLOR- } \\
\text { AMBEN, } \\
\text { METHYL } \\
\text { ESTER } \\
\text { WATER } \\
\text { FLTRD } \\
\text { (UG/L) }\end{array}$ & $\begin{array}{c}\text { CHLORI- } \\
\text { MURON, } \\
\text { WATER } \\
\text { FLTRD } \\
\text { REC } \\
\text { (UG/L) }\end{array}$ & $\begin{array}{c}\text { CHLORO- } \\
\text { THALO- } \\
\text { NIL, } \\
\text { WAT,FLT } \\
\text { GF } 0.7 \mathrm{U} \\
\text { REC } \\
\text { (UG/L) }\end{array}$ & $\begin{array}{c}\text { CHLOR- } \\
\text { PYRIFOS } \\
\text { DIS- } \\
\text { SOLVED } \\
\text { (UG/L) }\end{array}$ \\
\hline $\begin{array}{l}344800101324901 \\
345826100580501 \\
351656101161101 \\
351914101204401 \\
352035100293301\end{array}$ & $\begin{array}{l}<.08 \\
<.08 \\
<.08 \\
<.08 \\
<.08\end{array}$ & $\begin{array}{l}<.06 \\
<.06 \\
<.06 \\
<.06 \\
<.06\end{array}$ & $\begin{array}{l}<.002 \\
<.002 \\
<.002 \\
<.002 \\
<.002\end{array}$ & $\begin{array}{l}<.081 \\
<.081 \\
<.081 \\
<.081 \\
<.081\end{array}$ & $\begin{array}{l}<.06 \\
<.06 \\
<.06 \\
<.06 \\
<.06\end{array}$ & $\begin{array}{l}<.003 \\
<.003 \\
<.003 \\
<.003 \\
<.003\end{array}$ & $\begin{array}{l}<.06 \\
<.06 \\
<.06 \\
<.06 \\
<.06\end{array}$ & $\begin{array}{l}<.003 \\
<.003 \\
<.003 \\
<.003 \\
<.003\end{array}$ & $\begin{array}{l}<.11 \\
<.11 \\
<.11 \\
<.11 \\
<.11\end{array}$ & $\begin{array}{l}<.037 \\
<.037 \\
<.037 \\
<.037 \\
<.037\end{array}$ & $\begin{array}{l}<.05 \\
<.05 \\
<.05 \\
<.05 \\
<.05\end{array}$ & $\begin{array}{l}<.004 \\
<.004 \\
<.004 \\
<.004 \\
<.004\end{array}$ \\
\hline $\begin{array}{l}352249100425401 \\
352513101372101 \\
352909101084001 \\
353110100550401 \\
353941102350201\end{array}$ & $\begin{array}{l}<.08 \\
<.08 \\
<.08 \\
<.08 \\
<.08\end{array}$ & $\begin{array}{l}<.06 \\
<.06 \\
<.06 \\
<.06 \\
<.06\end{array}$ & $\begin{array}{l}<.002 \\
<.002 \\
<.002 \\
<.002 \\
<.002\end{array}$ & $\begin{array}{l}<.081 \\
<.081 \\
<.081 \\
<.081 \\
<.081\end{array}$ & $\begin{array}{l}<.06 \\
<.06 \\
<.06 \\
<.06 \\
<.06\end{array}$ & $\begin{array}{l}<.003 \\
<.003 \\
<.003 \\
<.003 \\
<.003\end{array}$ & $\begin{array}{l}<.06 \\
<.06 \\
<.06 \\
<.06 \\
<.06\end{array}$ & $\begin{array}{l}<.003 \\
<.003 \\
<.003 \\
<.003 \\
<.003\end{array}$ & $\begin{array}{l}<.11 \\
<.11 \\
<.11 \\
<.11 \\
<.11\end{array}$ & $\begin{array}{l}<.037 \\
<.037 \\
<.037 \\
<.037 \\
<.037\end{array}$ & $\begin{array}{l}<.05 \\
<.05 \\
<.05 \\
<.05 \\
<.05\end{array}$ & $\begin{array}{l}<.004 \\
<.004 \\
<.004 \\
<.004 \\
<.004\end{array}$ \\
\hline $\begin{array}{l}354248100501501 \\
354331102183601 \\
354348102543601 \\
354656099480301 \\
354728102295901\end{array}$ & $\begin{array}{l}<.08 \\
<.08 \\
<.08 \\
<.08 \\
<.08\end{array}$ & $\begin{array}{l}<.06 \\
<.06 \\
<.06 \\
<.06 \\
<.06\end{array}$ & $\begin{array}{l}<.002 \\
<.002 \\
<.002 \\
<.002 \\
<.002\end{array}$ & $\begin{array}{l}<.081 \\
<.081 \\
<.081 \\
<.081 \\
<.081\end{array}$ & $\begin{array}{l}<.06 \\
<.06 \\
<.06 \\
<.06 \\
<.06\end{array}$ & $\begin{array}{l}<.003 \\
<.003 \\
<.003 \\
<.003 \\
<.003\end{array}$ & $\begin{array}{l}<.06 \\
<.06 \\
<.06 \\
<.06 \\
<.06\end{array}$ & $\begin{array}{l}<.003 \\
<.003 \\
<.003 \\
<.003 \\
<.003\end{array}$ & $\begin{array}{l}<.11 \\
<.11 \\
<.11 \\
<.11 \\
<.11\end{array}$ & $\begin{array}{l}<.037 \\
<.037 \\
<.037 \\
<.037 \\
<.037\end{array}$ & $\begin{array}{l}<.05 \\
<.05 \\
<.05 \\
<.05 \\
<.05\end{array}$ & $\begin{array}{l}<.004 \\
<.004 \\
<.004 \\
<.004 \\
<.004\end{array}$ \\
\hline $\begin{array}{l}354918102020901 \\
355701100313001 \\
355852101274101 \\
355916103215201 \\
360703102361901\end{array}$ & $\begin{array}{l}<.08 \\
<.08 \\
<.08 \\
<.08 \\
<.08\end{array}$ & $\begin{array}{l}<.06 \\
<.06 \\
<.06 \\
<.06 \\
<.06\end{array}$ & $\begin{array}{l}<.002 \\
<.002 \\
<.002 \\
<.002 \\
<.002\end{array}$ & $\begin{array}{l}<.081 \\
<.081 \\
<.081 \\
<.081 \\
<.081\end{array}$ & $\begin{array}{l}<.06 \\
<.06 \\
<.06 \\
<.06 \\
<.06\end{array}$ & $\begin{array}{l}\mathrm{E} .116 \\
<.003 \\
<.003 \\
<.003 \\
<.003\end{array}$ & $\begin{array}{l}<.06 \\
<.06 \\
<.06 \\
<.06 \\
<.06\end{array}$ & $\begin{array}{l}<.003 \\
<.003 \\
<.003 \\
<.003 \\
<.003\end{array}$ & $\begin{array}{l}<.11 \\
<.11 \\
<.11 \\
<.11 \\
<.11\end{array}$ & $\begin{array}{l}<.037 \\
<.037 \\
<.037 \\
<.037 \\
<.037\end{array}$ & $\begin{array}{l}<.05 \\
<.05 \\
<.05 \\
<.05 \\
<.05\end{array}$ & $\begin{aligned} & .007 \\
&<.004 \\
&<.004 \\
&<.004 \\
&<.004\end{aligned}$ \\
\hline $\begin{array}{l}360838102560301 \\
360944100162101 \\
361014100221001 \\
361049100564901 \\
361054101393601\end{array}$ & $\begin{array}{l}<.08 \\
<.08 \\
<.08 \\
<.08 \\
<.08\end{array}$ & $\begin{array}{l}<.06 \\
<.06 \\
<.06 \\
<.06 \\
<.06\end{array}$ & $\begin{array}{l}<.002 \\
<.002 \\
<.002 \\
<.002 \\
<.002\end{array}$ & $\begin{array}{l}<.081 \\
<.081 \\
<.081 \\
<.081 \\
<.081\end{array}$ & $\begin{array}{l}<.06 \\
<.06 \\
<.06 \\
<.06 \\
<.06\end{array}$ & $\begin{array}{l}<.003 \\
<.003 \\
<.003 \\
<.003 \\
<.003\end{array}$ & $\begin{array}{l}<.06 \\
<.06 \\
<.06 \\
<.06 \\
<.06\end{array}$ & $\begin{array}{l}<.003 \\
<.003 \\
<.003 \\
<.003 \\
<.003\end{array}$ & $\begin{array}{l}<.11 \\
<.11 \\
<.11 \\
-- \\
<.11\end{array}$ & $\begin{array}{l}<.037 \\
<.037 \\
<.037 \\
<.037 \\
<.037\end{array}$ & $\begin{array}{l}<.05 \\
<.05 \\
<.05 \\
<.05 \\
<.05\end{array}$ & $\begin{array}{l}<.004 \\
<.004 \\
<.004 \\
<.004 \\
<.004\end{array}$ \\
\hline $\begin{array}{l}361114099420501 \\
361517102065301 \\
362115101173901 \\
362134102035101 \\
362615100435801\end{array}$ & $\begin{array}{l}<.08 \\
<.08 \\
<.08 \\
<.08 \\
<.08\end{array}$ & $\begin{array}{l}<.06 \\
<.06 \\
<.06 \\
<.06 \\
<.06\end{array}$ & $\begin{array}{l}<.002 \\
<.002 \\
<.002 \\
<.002 \\
<.002\end{array}$ & $\begin{array}{l}<.081 \\
<.081 \\
<.081 \\
<.081 \\
<.081\end{array}$ & $\begin{array}{l}<.06 \\
<.06 \\
<.06 \\
<.06 \\
<.06\end{array}$ & $\begin{array}{l}<.003 \\
<.003 \\
<.003 \\
<.003 \\
<.003\end{array}$ & $\begin{array}{l}<.06 \\
<.06 \\
<.06 \\
<.06 \\
<.06\end{array}$ & $\begin{array}{l}<.003 \\
<.003 \\
<.003 \\
<.003 \\
<.003\end{array}$ & $\begin{array}{l}<.11 \\
<.11 \\
<.11 \\
<.11 \\
<.11\end{array}$ & $\begin{array}{l}<.037 \\
<.037 \\
<.037 \\
<.037 \\
<.037\end{array}$ & $\begin{array}{l}<.05 \\
<.05 \\
<.05 \\
<.05 \\
<.05\end{array}$ & $\begin{array}{l}<.004 \\
<.004 \\
<.004 \\
<.004 \\
<.004\end{array}$ \\
\hline $\begin{array}{l}362744102334901 \\
363057101384701 \\
363104100035501 \\
363154099310401 \\
363157102565601\end{array}$ & $\begin{array}{l}<.08 \\
<.08 \\
<.08 \\
<.08 \\
<.08\end{array}$ & $\begin{array}{l}<.06 \\
<.06 \\
<.06 \\
<.06 \\
<.06\end{array}$ & $\begin{array}{l}<.002 \\
<.002 \\
<.002 \\
<.002 \\
<.002\end{array}$ & $\begin{array}{l}<.081 \\
<.081 \\
<.081 \\
<.081 \\
<.081\end{array}$ & $\begin{array}{l}<.06 \\
<.06 \\
<.06 \\
<.06 \\
<.06\end{array}$ & $\begin{array}{l}<.003 \\
<.003 \\
<.003 \\
<.003 \\
<.003\end{array}$ & $\begin{array}{l}<.06 \\
<.06 \\
<.06 \\
<.06 \\
<.06\end{array}$ & $\begin{array}{l}<.003 \\
<.003 \\
<.003 \\
<.003 \\
<.003\end{array}$ & $\begin{array}{l}<.11 \\
<.11 \\
<.11 \\
<.11 \\
<.11\end{array}$ & $\begin{array}{l}<.037 \\
<.037 \\
<.037 \\
<.037 \\
<.037\end{array}$ & $\begin{array}{l}<.05 \\
<.05 \\
<.05 \\
<.05 \\
<.05\end{array}$ & $\begin{array}{l}<.004 \\
<.004 \\
<.004 \\
<.004 \\
<.004\end{array}$ \\
\hline $\begin{array}{l}363239100301801 \\
363427102440401 \\
364219101394101 \\
364411102321201 \\
365223102113001\end{array}$ & $\begin{array}{l}<.08 \\
<.08 \\
<.08 \\
<.08 \\
<.08\end{array}$ & $\begin{array}{l}<.06 \\
<.06 \\
<.06 \\
<.06 \\
<.06\end{array}$ & $\begin{array}{l}<.002 \\
<.002 \\
<.002 \\
<.002 \\
<.002\end{array}$ & $\begin{array}{l}<.081 \\
<.081 \\
<.081 \\
<.081 \\
<.081\end{array}$ & $\begin{array}{l}<.06 \\
<.06 \\
<.06 \\
<.06 \\
<.06\end{array}$ & $\begin{array}{l}<.003 \\
<.003 \\
<.003 \\
<.003 \\
<.003\end{array}$ & $\begin{array}{l}<.06 \\
<.06 \\
<.06 \\
<.06 \\
<.06\end{array}$ & $\begin{array}{l}<.003 \\
<.003 \\
<.003 \\
<.003 \\
<.003\end{array}$ & $\begin{array}{l}<.11 \\
<.11 \\
<.11 \\
<.11 \\
<.11\end{array}$ & $\begin{array}{l}<.037 \\
<.037 \\
<.037 \\
<.037 \\
<.037\end{array}$ & $\begin{array}{l}<.05 \\
<.05 \\
<.05 \\
<.05 \\
<.05\end{array}$ & $\begin{array}{l}<.004 \\
<.004 \\
<.004 \\
<.004 \\
<.004\end{array}$ \\
\hline $\begin{array}{l}365422101083701 \\
365445100381901 \\
365821101375301 \\
365934101573001 \\
370358100510301\end{array}$ & $\begin{array}{l}<.08 \\
<.08 \\
<.08 \\
<.08 \\
<.08\end{array}$ & $\begin{array}{l}<.06 \\
<.06 \\
<.06 \\
<.06 \\
<.06\end{array}$ & $\begin{array}{l}<.002 \\
<.002 \\
<.002 \\
<.002 \\
<.002\end{array}$ & $\begin{array}{l}<.081 \\
<.081 \\
<.081 \\
<.081 \\
<.081\end{array}$ & $\begin{array}{l}<.06 \\
<.06 \\
<.06 \\
<.06 \\
<.06\end{array}$ & $\begin{array}{l}<.003 \\
<.003 \\
<.003 \\
<.003 \\
<.003\end{array}$ & $\begin{array}{l}<.06 \\
<.06 \\
<.06 \\
<.06 \\
<.06\end{array}$ & $\begin{array}{l}<.003 \\
<.003 \\
<.003 \\
<.003 \\
<.003\end{array}$ & $\begin{array}{l}<.11 \\
<.11 \\
<.11 \\
<.11 \\
<.11\end{array}$ & $\begin{array}{l}<.037 \\
<.037 \\
<.037 \\
<.037 \\
<.037\end{array}$ & $\begin{array}{l}<.05 \\
<.05 \\
<.05 \\
<.05 \\
<.05\end{array}$ & $\begin{array}{l}<.004 \\
<.004 \\
<.004 \\
<.004 \\
<.004\end{array}$ \\
\hline $\begin{array}{l}370458101514401 \\
370724100281601 \\
371738101220301 \\
372534100443501 \\
372649101344701\end{array}$ & $\begin{array}{l}<.08 \\
<.08 \\
<.08 \\
<.08 \\
<.08\end{array}$ & $\begin{array}{l}<.06 \\
<.06 \\
<.06 \\
<.06 \\
<.06\end{array}$ & $\begin{array}{l}<.002 \\
<.002 \\
<.002 \\
<.002 \\
<.002\end{array}$ & $\begin{array}{l}<.081 \\
<.081 \\
<.081 \\
<.081 \\
<.081\end{array}$ & $\begin{array}{l}<.06 \\
<.06 \\
<.06 \\
<.06 \\
<.06\end{array}$ & $\begin{array}{l}<.003 \\
<.003 \\
<.003 \\
<.003 \\
<.003\end{array}$ & $\begin{array}{l}<.06 \\
<.06 \\
<.06 \\
<.06 \\
<.06\end{array}$ & $\begin{array}{l}<.003 \\
<.003 \\
<.003 \\
<.003 \\
<.003\end{array}$ & $\begin{array}{l}<.11 \\
<.11 \\
<.11 \\
<.11 \\
<.11\end{array}$ & $\begin{array}{l}<.037 \\
<.037 \\
<.037 \\
<.037 \\
<.037\end{array}$ & $\begin{array}{l}<.05 \\
<.05 \\
<.05 \\
<.05 \\
<.05\end{array}$ & $\begin{array}{l}<.004 \\
<.004 \\
<.004 \\
<.004 \\
<.004\end{array}$ \\
\hline $\begin{array}{l}372956099512201 \\
373229101193201 \\
373345101070801 \\
373507102162001 \\
373527100312701\end{array}$ & $\begin{array}{l}<.08 \\
<.08 \\
<.08 \\
<.08 \\
<.08\end{array}$ & $\begin{array}{l}<.06 \\
<.06 \\
<.06 \\
<.06 \\
<.06\end{array}$ & $\begin{array}{l}<.002 \\
<.002 \\
<.002 \\
<.002 \\
<.002\end{array}$ & $\begin{array}{l}<.081 \\
<.081 \\
<.081 \\
<.081 \\
<.081\end{array}$ & $\begin{array}{l}<.06 \\
<.06 \\
<.06 \\
<.06 \\
<.06\end{array}$ & $\begin{array}{l}<.003 \\
<.003 \\
<.003 \\
<.003 \\
<.003\end{array}$ & $\begin{array}{l}<.06 \\
<.06 \\
<.06 \\
<.06 \\
<.06\end{array}$ & $\begin{array}{l}<.003 \\
<.003 \\
<.003 \\
<.003 \\
<.003\end{array}$ & $\begin{array}{l}<.11 \\
<.11 \\
<.11 \\
<.11 \\
<.11\end{array}$ & $\begin{array}{l}<.037 \\
<.037 \\
<.037 \\
<.037 \\
<.037\end{array}$ & $\begin{array}{l}<.05 \\
<.05 \\
<.05 \\
<.05 \\
<.05\end{array}$ & $\begin{array}{l}<.004 \\
<.004 \\
<.004 \\
<.004 \\
<.004\end{array}$ \\
\hline $\begin{array}{l}373559102314901 \\
373732099291201 \\
374535102110301 \\
374650100181901 \\
375129100532301\end{array}$ & $\begin{array}{l}<.08 \\
<.08 \\
<.08 \\
<.08 \\
<.08\end{array}$ & $\begin{array}{l}<.06 \\
<.06 \\
<.06 \\
<.06 \\
<.06\end{array}$ & $\begin{array}{l}<.002 \\
<.002 \\
<.002 \\
<.002 \\
<.002\end{array}$ & $\begin{array}{l}<.081 \\
<.081 \\
<.081 \\
<.081 \\
<.081\end{array}$ & $\begin{array}{l}<.06 \\
<.06 \\
<.06 \\
<.06 \\
<.06\end{array}$ & $\begin{array}{l}<.003 \\
<.003 \\
<.003 \\
<.003 \\
<.003\end{array}$ & $\begin{array}{l}<.06 \\
<.06 \\
<.06 \\
<.06 \\
<.06\end{array}$ & $\begin{array}{l}<.003 \\
<.003 \\
<.003 \\
<.003 \\
<.003\end{array}$ & $\begin{array}{l}<.11 \\
<.11 \\
<.11 \\
<.11 \\
<.11\end{array}$ & $\begin{array}{l}<.037 \\
<.037 \\
<.037 \\
<.037 \\
<.037\end{array}$ & $\begin{array}{l}<.05 \\
<.05 \\
<.05 \\
<.05 \\
<.05\end{array}$ & $\begin{array}{l}<.004 \\
<.004 \\
<.004 \\
<.004 \\
<.004\end{array}$ \\
\hline $\begin{array}{l}375447099245001 \\
375828101111801 \\
380331100352801 \\
382947100443201 \\
383008101315601\end{array}$ & $\begin{array}{l}<.08 \\
<.08 \\
<.08 \\
<.08 \\
<.08\end{array}$ & $\begin{array}{l}<.06 \\
<.06 \\
<.06 \\
<.06 \\
<.06\end{array}$ & $\begin{array}{l}<.002 \\
<.002 \\
<.002 \\
<.002 \\
<.002\end{array}$ & $\begin{array}{l}<.081 \\
<.081 \\
<.081 \\
<.081 \\
<.081\end{array}$ & $\begin{array}{l}<.06 \\
<.06 \\
<.06 \\
<.06 \\
<.06\end{array}$ & $\begin{array}{l}<.003 \\
<.003 \\
<.003 \\
<.003 \\
<.003\end{array}$ & $\begin{array}{l}<.06 \\
<.06 \\
<.06 \\
<.06 \\
<.06\end{array}$ & $\begin{array}{l}<.003 \\
<.003 \\
<.003 \\
<.003 \\
<.003\end{array}$ & $\begin{array}{l}<.11 \\
<.11 \\
<.11 \\
<.11 \\
<.11\end{array}$ & $\begin{array}{l}<.037 \\
<.037 \\
<.037 \\
<.037 \\
<.037\end{array}$ & $\begin{array}{l}<.05 \\
<.05 \\
<.05 \\
<.05 \\
<.05\end{array}$ & $\begin{array}{l}<.004 \\
<.004 \\
<.004 \\
<.004 \\
<.004\end{array}$ \\
\hline $\begin{array}{l}383758101195801 \\
383919101040101 \\
385210100164501 \\
385904099522201 \\
390622101003201\end{array}$ & $\begin{array}{l}<.08 \\
<.08 \\
<.08 \\
<.08 \\
<.08\end{array}$ & $\begin{array}{l}<.06 \\
<.06 \\
<.06 \\
<.06 \\
<.06\end{array}$ & $\begin{array}{l}<.002 \\
<.002 \\
<.002 \\
<.002 \\
<.002\end{array}$ & $\begin{array}{l}<.081 \\
<.081 \\
<.081 \\
<.081 \\
<.081\end{array}$ & $\begin{array}{l}<.06 \\
<.06 \\
<.06 \\
<.06 \\
<.06\end{array}$ & $\begin{array}{l}<.003 \\
<.003 \\
<.003 \\
<.003 \\
<.003\end{array}$ & $\begin{array}{l}<.06 \\
<.06 \\
<.06 \\
<.06 \\
<.06\end{array}$ & $\begin{array}{l}<.003 \\
<.003 \\
<.003 \\
<.003 \\
<.003\end{array}$ & $\begin{array}{l}<.11 \\
<.11 \\
<.11 \\
<.11 \\
<.11\end{array}$ & $\begin{array}{l}<.037 \\
<.037 \\
<.037 \\
<.037 \\
<.037\end{array}$ & $\begin{array}{l}<.05 \\
<.05 \\
<.05 \\
<.05 \\
<.05\end{array}$ & $\begin{array}{l}<.004 \\
<.004 \\
<.004 \\
<.004 \\
<.004\end{array}$ \\
\hline
\end{tabular}




\begin{tabular}{|c|c|c|c|c|c|c|c|c|c|c|c|c|}
\hline STATION NUMBER & $\begin{array}{c}\text { CLOPYR- } \\
\text { ALID, } \\
\text { WATER, } \\
\text { FLTRD, } \\
\text { GF } 0.7 \mathrm{U} \\
\text { REC } \\
\text { (UG/L) }\end{array}$ & $\begin{array}{l}\text { CYANA- } \\
\text { ZINE, } \\
\text { WATER, } \\
\text { DISS, } \\
\text { REC } \\
\text { (UG/L) }\end{array}$ & $\begin{array}{l}\text { SI- } \\
\text { CLOATE, } \\
\text { WATER, } \\
\text { DISS, } \\
\text { REC } \\
\text { (UG/L) }\end{array}$ & $\begin{array}{c}\text { DACTHAL } \\
\text { MONO- } \\
\text { ACID, } \\
\text { WAT, FLT } \\
\text { GF 0.7U } \\
\text { REC } \\
\text { (UG/L) }\end{array}$ & $\begin{array}{l}\text { DCPA } \\
\text { WATER } \\
\text { FLTRD } \\
0.7 \text { U } \\
\text { GE, REC } \\
\text { (UG/L) }\end{array}$ & $\begin{array}{l}\text { DEETHYL } \\
\text { ATRA- } \\
\text { ZINE, } \\
\text { WATER, } \\
\text { DISS, } \\
\text { REC } \\
\text { (UG/L) }\end{array}$ & $\begin{array}{l}\text { DEETHYL } \\
\text { DEISO- } \\
\text { PROPYL } \\
\text { ATRAZIN } \\
\text { DISS, } \\
\text { REC } \\
\text { (UG/L) }\end{array}$ & $\begin{array}{c}\text { DEISO- } \\
\text { PROPYL } \\
\text { ATRAZIN } \\
\text { WATER, } \\
\text { DISS, } \\
\text { REC } \\
\text { (UG/L) }\end{array}$ & $\begin{array}{c}\text { DI- } \\
\text { AZINON, } \\
\text { DIS- } \\
\text { SOLVED } \\
\text { (UG/L) }\end{array}$ & $\begin{array}{c}\text { DICAMBA } \\
\text { WATER, } \\
\text { FLTRD, } \\
\text { GF } 0.7 \mathrm{U} \\
\text { REC } \\
\text { (UG/L) }\end{array}$ & $\begin{array}{c}\text { DICHLOR } \\
\text { PROP, } \\
\text { WATER, } \\
\text { FLTRD, } \\
\text { GF } 0.7 \mathrm{U} \\
\text { REC } \\
\text { (UG/L) }\end{array}$ & $\begin{array}{l}\text { DI- } \\
\text { ELDRIN } \\
\text { DIS- } \\
\text { SOLVED } \\
\text { (UG/L) }\end{array}$ \\
\hline $\begin{array}{l}344800101324901 \\
345826100580501 \\
351656101161101 \\
351914101204401 \\
352035100293301\end{array}$ & $\begin{array}{l}<.04 \\
<.04 \\
<.04 \\
<.04 \\
<.04\end{array}$ & $\begin{array}{l}<.004 \\
<.004 \\
<.004 \\
<.004 \\
<.004\end{array}$ & $\begin{array}{l}<.05 \\
<.05 \\
<.05 \\
<.05 \\
<.05\end{array}$ & $\begin{array}{l}<.07 \\
<.07 \\
<.07 \\
<.07 \\
<.07\end{array}$ & $\begin{array}{l}<.002 \\
<.002 \\
<.002 \\
<.002 \\
<.002\end{array}$ & $\begin{array}{l}<.002 \\
<.002 \\
<.002 \\
<.002 \\
\mathrm{E} .011\end{array}$ & $\begin{array}{l}<.06 \\
<.06 \\
<.06 \\
<.06 \\
<.06\end{array}$ & $\begin{array}{l}<.07 \\
<.07 \\
<.07 \\
<.07 \\
<.07\end{array}$ & $\begin{array}{l}<.002 \\
<.002 \\
<.002 \\
<.002 \\
<.002\end{array}$ & $\begin{array}{l}<.10 \\
<.10 \\
<.10 \\
<.10 \\
<.10\end{array}$ & $\begin{array}{l}<.05 \\
<.05 \\
<.05 \\
<.05 \\
<.05\end{array}$ & $\begin{array}{l}<.001 \\
<.001 \\
<.001 \\
<.001 \\
<.001\end{array}$ \\
\hline $\begin{array}{l}352249100425401 \\
352513101372101 \\
352909101084001 \\
353110100550401 \\
353941102350201\end{array}$ & $\begin{array}{l}<.04 \\
<.04 \\
<.04 \\
<.04 \\
<.04\end{array}$ & $\begin{array}{l}<.004 \\
<.004 \\
<.004 \\
<.004 \\
<.004\end{array}$ & $\begin{array}{l}<.05 \\
<.05 \\
<.05 \\
<.05 \\
<.05\end{array}$ & $\begin{array}{l}<.07 \\
<.07 \\
<.07 \\
<.07 \\
<.07\end{array}$ & $\begin{array}{l}<.002 \\
<.002 \\
<.002 \\
<.002 \\
<.002\end{array}$ & $\begin{array}{l}<.002 \\
<.002 \\
<.002 \\
<.002 \\
<.002\end{array}$ & $\begin{array}{l}<.06 \\
<.06 \\
<.06 \\
<.06 \\
<.06\end{array}$ & $\begin{array}{l}<.07 \\
<.07 \\
<.07 \\
<.07 \\
<.07\end{array}$ & $\begin{array}{l}<.002 \\
<.002 \\
<.002 \\
<.002 \\
<.002\end{array}$ & $\begin{array}{l}<.10 \\
<.10 \\
<.10 \\
<.10 \\
<.10\end{array}$ & $\begin{array}{l}<.05 \\
<.05 \\
<.05 \\
<.05 \\
<.05\end{array}$ & $\begin{array}{l}<.001 \\
<.001 \\
<.001 \\
<.001 \\
<.001\end{array}$ \\
\hline $\begin{array}{l}354248100501501 \\
354331102183601 \\
354348102543601 \\
354656099480301 \\
354728102295901\end{array}$ & $\begin{array}{l}<.04 \\
<.04 \\
<.04 \\
<.04 \\
<.04\end{array}$ & $\begin{array}{l}<.004 \\
<.004 \\
<.004 \\
<.004 \\
<.004\end{array}$ & $\begin{array}{l}<.05 \\
<.05 \\
<.05 \\
<.05 \\
<.05\end{array}$ & $\begin{array}{l}<.07 \\
<.07 \\
<.07 \\
<.07 \\
<.07\end{array}$ & $\begin{array}{l}<.002 \\
<.002 \\
<.002 \\
<.002 \\
<.002\end{array}$ & $\begin{array}{l}<.002 \\
<.002 \\
<.002 \\
<.002 \\
<.002\end{array}$ & $\begin{array}{l}<.06 \\
<.06 \\
<.06 \\
<.06 \\
<.06\end{array}$ & $\begin{array}{l}<.07 \\
<.07 \\
<.07 \\
<.07 \\
<.07\end{array}$ & $\begin{array}{l}<.002 \\
<.002 \\
<.002 \\
<.002 \\
<.002\end{array}$ & $\begin{array}{l}<.10 \\
<.10 \\
<.10 \\
<.10 \\
<.10\end{array}$ & $\begin{array}{l}<.05 \\
<.05 \\
<.05 \\
<.05 \\
<.05\end{array}$ & $\begin{array}{l}<.001 \\
<.001 \\
<.001 \\
<.001 \\
<.001\end{array}$ \\
\hline $\begin{array}{l}354918102020901 \\
355701100313001 \\
355852101274101 \\
355916103215201 \\
360703102361901\end{array}$ & $\begin{array}{l}<.04 \\
<.04 \\
<.04 \\
<.04 \\
<.04\end{array}$ & $\begin{array}{l}<.004 \\
<.004 \\
<.004 \\
<.004 \\
<.004\end{array}$ & $\begin{array}{l}<.05 \\
<.05 \\
<.05 \\
<.05 \\
<.05\end{array}$ & $\begin{array}{l}<.07 \\
<.07 \\
<.07 \\
<.07 \\
<.07\end{array}$ & $\begin{array}{l}<.002 \\
<.002 \\
<.002 \\
<.002 \\
<.002\end{array}$ & $\begin{array}{l}<.006 \\
<.002 \\
<.002 \\
<.002 \\
<.002\end{array}$ & $\begin{array}{l}<.06 \\
<.06 \\
<.06 \\
<.06 \\
<.06\end{array}$ & $\begin{array}{l}<.07 \\
<.07 \\
<.07 \\
<.07 \\
<.07\end{array}$ & $\begin{array}{l}.089 \\
<.002 \\
<.002 \\
<.002 \\
<.002\end{array}$ & $\begin{array}{l}<.10 \\
<.10 \\
<.10 \\
<.10 \\
<.10\end{array}$ & $\begin{array}{l}<.05 \\
<.05 \\
-- \\
<.05 \\
<.05\end{array}$ & $\begin{array}{l}<.001 \\
<.001 \\
<.001 \\
<.001 \\
<.001\end{array}$ \\
\hline $\begin{array}{l}360838102560301 \\
360944100162101 \\
361014100221001 \\
361049100564901 \\
361054101393601\end{array}$ & $\begin{array}{l}<.04 \\
<.04 \\
<.04 \\
<.04 \\
<.04\end{array}$ & $\begin{array}{l}<.004 \\
<.004 \\
<.004 \\
<.004 \\
<.004\end{array}$ & $\begin{array}{l}<.05 \\
<.05 \\
<.05 \\
<.05 \\
<.05\end{array}$ & $\begin{array}{l}<.07 \\
<.07 \\
<.07 \\
<.07 \\
<.07\end{array}$ & $\begin{array}{l}<.002 \\
<.002 \\
<.002 \\
<.002 \\
<.002\end{array}$ & $\begin{array}{l}<.002 \\
<.002 \\
<.002 \\
<.002 \\
<.002\end{array}$ & $\begin{array}{l}<.06 \\
<.06 \\
<.06 \\
<.06 \\
<.06\end{array}$ & $\begin{array}{l}<.07 \\
<.07 \\
<.07 \\
<.07 \\
<.07\end{array}$ & $\begin{array}{l}<.002 \\
<.002 \\
<.002 \\
<.002 \\
<.002\end{array}$ & $\begin{array}{l}<.10 \\
<.10 \\
<.10 \\
<.10 \\
<.10\end{array}$ & $\begin{array}{l}<.05 \\
<.05 \\
<.05 \\
<.05 \\
<.05\end{array}$ & $\begin{array}{l}<.001 \\
<.001 \\
<.001 \\
<.001 \\
<.001\end{array}$ \\
\hline $\begin{array}{l}361114099420501 \\
361517102065301 \\
362115101173901 \\
362134102035101 \\
362615100435801\end{array}$ & $\begin{array}{l}<.04 \\
<.04 \\
<.04 \\
<.04 \\
<.04\end{array}$ & $\begin{array}{l}<.004 \\
<.004 \\
<.004 \\
<.004 \\
<.004\end{array}$ & $\begin{array}{l}<.05 \\
<.05 \\
<.05 \\
<.05 \\
<.05\end{array}$ & $\begin{array}{l}<.07 \\
<.07 \\
<.07 \\
<.07 \\
<.07\end{array}$ & $\begin{array}{l}<.002 \\
<.002 \\
<.002 \\
<.002 \\
<.002\end{array}$ & $\begin{array}{l}<.002 \\
<.002 \\
\mathrm{E} .318 \\
<.002 \\
<.002\end{array}$ & $\begin{array}{l}<.06 \\
<.06 \\
<.06 \\
<.06 \\
<.06\end{array}$ & $\begin{array}{l}<.07 \\
<.07 \\
<.07 \\
<.07 \\
<.07\end{array}$ & $\begin{array}{l}<.002 \\
<.002 \\
<.002 \\
<.002 \\
<.002\end{array}$ & $\begin{array}{l}<.10 \\
<.10 \\
<.10 \\
<.10 \\
<.10\end{array}$ & $\begin{array}{l}<.05 \\
<.05 \\
<.05 \\
<.05 \\
<.05\end{array}$ & $\begin{array}{l}<.001 \\
<.001 \\
<.001 \\
<.001 \\
<.001\end{array}$ \\
\hline $\begin{array}{l}362744102334901 \\
363057101384701 \\
363104100035501 \\
363154099310401 \\
363157102565601\end{array}$ & $\begin{array}{l}<.04 \\
<.04 \\
<.04 \\
<.04 \\
<.04\end{array}$ & $\begin{array}{l}<.004 \\
<.004 \\
<.004 \\
<.004 \\
<.004\end{array}$ & $\begin{array}{l}<.05 \\
<.05 \\
<.05 \\
<.05 \\
<.05\end{array}$ & $\begin{array}{l}<.07 \\
<.07 \\
<.07 \\
<.07 \\
<.07\end{array}$ & $\begin{array}{l}<.002 \\
<.002 \\
<.002 \\
<.002 \\
<.002\end{array}$ & $\begin{array}{l}<.002 \\
<.002 \\
<.002 \\
<.002 \\
<.002\end{array}$ & $\begin{array}{l}<.06 \\
<.06 \\
<.06 \\
<.06 \\
<.06\end{array}$ & $\begin{array}{l}<.07 \\
<.07 \\
<.07 \\
<.07 \\
<.07\end{array}$ & $\begin{array}{l}<.002 \\
<.002 \\
<.002 \\
<.002 \\
<.002\end{array}$ & $\begin{array}{l}<.10 \\
<.10 \\
<.10 \\
<.10 \\
<.10\end{array}$ & $\begin{array}{l}<.05 \\
<.05 \\
<.05 \\
<.05 \\
<.05\end{array}$ & $\begin{array}{l}<.001 \\
<.001 \\
<.001 \\
<.001 \\
<.001\end{array}$ \\
\hline $\begin{array}{l}363239100301801 \\
363427102440401 \\
364219101394101 \\
364411102321201 \\
365223102113001\end{array}$ & $\begin{array}{l}<.04 \\
<.04 \\
<.04 \\
<.04 \\
<.04\end{array}$ & $\begin{array}{l}<.004 \\
<.004 \\
<.004 \\
<.004 \\
<.004\end{array}$ & $\begin{array}{l}<.05 \\
<.05 \\
<.05 \\
<.05 \\
<.05\end{array}$ & $\begin{array}{l}<.07 \\
<.07 \\
<.07 \\
<.07 \\
<.07\end{array}$ & $\begin{array}{l}<.002 \\
<.002 \\
<.002 \\
<.002 \\
<.002\end{array}$ & $\begin{array}{l}\mathrm{E} .006 \\
<.002 \\
<.002 \\
<.002 \\
<.002\end{array}$ & $\begin{array}{l}<.06 \\
<.06 \\
<.06 \\
<.06 \\
<.06\end{array}$ & $\begin{array}{l}<.07 \\
<.07 \\
<.07 \\
<.07 \\
<.07\end{array}$ & $\begin{array}{l}<.002 \\
<.002 \\
<.002 \\
<.002 \\
<.002\end{array}$ & $\begin{array}{l}<.10 \\
<.10 \\
<.10 \\
<.10 \\
<.10\end{array}$ & $\begin{array}{l}-- \\
<.05 \\
<.05 \\
<.05 \\
<.05\end{array}$ & $\begin{array}{l}<.001 \\
<.001 \\
<.001 \\
<.001 \\
<.001\end{array}$ \\
\hline $\begin{array}{l}365422101083701 \\
365445100381901 \\
365821101375301 \\
365934101573001 \\
370358100510301\end{array}$ & $\begin{array}{l}<.04 \\
<.04 \\
<.04 \\
<.04 \\
<.04\end{array}$ & $\begin{array}{l}<.004 \\
<.004 \\
<.004 \\
<.004 \\
<.004\end{array}$ & $\begin{array}{l}<.05 \\
<.05 \\
<.05 \\
<.05 \\
<.05\end{array}$ & $\begin{array}{l}<.07 \\
<.07 \\
<.07 \\
<.07 \\
<.07\end{array}$ & $\begin{array}{l}<.002 \\
<.002 \\
<.002 \\
<.002 \\
<.002\end{array}$ & $\begin{array}{l}<.002 \\
<.002 \\
<.002 \\
<.002 \\
<.002\end{array}$ & $\begin{array}{l}<.06 \\
<.06 \\
<.06 \\
<.06 \\
<.06\end{array}$ & $\begin{array}{l}<.07 \\
<.07 \\
<.07 \\
<.07 \\
<.07\end{array}$ & $\begin{array}{l}<.002 \\
<.002 \\
<.002 \\
<.002 \\
<.002\end{array}$ & $\begin{array}{l}<.10 \\
<.10 \\
<.10 \\
<.10 \\
<.10\end{array}$ & $\begin{array}{l}<.05 \\
<.05 \\
<.05 \\
<.05 \\
<.05\end{array}$ & $\begin{array}{l}<.001 \\
<.001 \\
<.001 \\
<.001 \\
<.001\end{array}$ \\
\hline $\begin{array}{l}370458101514401 \\
370724100281601 \\
371738101220301 \\
372534100443501 \\
372649101344701\end{array}$ & $\begin{array}{l}<.04 \\
<.04 \\
<.04 \\
<.04 \\
<.04\end{array}$ & $\begin{array}{l}<.004 \\
<.004 \\
<.004 \\
<.004 \\
<.004\end{array}$ & $\begin{array}{l}<.05 \\
<.05 \\
<.05 \\
<.05 \\
<.05\end{array}$ & $\begin{array}{l}<.07 \\
<.07 \\
<.07 \\
<.07 \\
<.07\end{array}$ & $\begin{array}{l}<.002 \\
<.002 \\
<.002 \\
<.002 \\
<.002\end{array}$ & $\begin{array}{l}<.002 \\
<.002 \\
<.002 \\
\mathrm{E} .046 \\
<.002\end{array}$ & $\begin{array}{l}<.06 \\
<.06 \\
<.06 \\
<.06 \\
<.06\end{array}$ & $\begin{array}{l}<.07 \\
<.07 \\
<.07 \\
<.07 \\
<.07\end{array}$ & $\begin{array}{l}<.002 \\
<.002 \\
<.002 \\
<.002 \\
<.002\end{array}$ & $\begin{array}{l}<.10 \\
<.10 \\
<.10 \\
<.10 \\
<.10\end{array}$ & $\begin{array}{l}<.05 \\
<.05 \\
<.05 \\
<.05 \\
<.05\end{array}$ & $\begin{array}{l}<.001 \\
<.001 \\
<.001 \\
<.001 \\
<.001\end{array}$ \\
\hline $\begin{array}{l}372956099512201 \\
373229101193201 \\
373345101070801 \\
373507102162001 \\
373527100312701\end{array}$ & $\begin{array}{l}<.04 \\
<.04 \\
<.04 \\
<.04 \\
<.04\end{array}$ & $\begin{array}{l}<.004 \\
<.004 \\
<.004 \\
<.004 \\
<.004\end{array}$ & $\begin{array}{l}<.05 \\
<.05 \\
<.05 \\
<.05 \\
<.05\end{array}$ & $\begin{array}{l}<.07 \\
<.07 \\
<.07 \\
<.07 \\
<.07\end{array}$ & $\begin{array}{l}<.002 \\
<.002 \\
<.002 \\
<.002 \\
<.002\end{array}$ & $\begin{array}{l}<.002 \\
<.002 \\
\mathrm{E} .462 \\
\mathrm{E} .004 \\
<.002\end{array}$ & $\begin{array}{l}<.06 \\
<.06 \\
<.06 \\
<.06 \\
<.06\end{array}$ & $\begin{array}{l}<.07 \\
<.07 \\
<.07 \\
<.07 \\
<.07\end{array}$ & $\begin{array}{l}<.002 \\
<.002 \\
<.002 \\
<.002 \\
<.002\end{array}$ & $\begin{array}{l}<.10 \\
<.10 \\
<.10 \\
<.10 \\
<.10\end{array}$ & $\begin{array}{l}<.05 \\
<.05 \\
-- \\
<.05 \\
<.05\end{array}$ & $\begin{array}{l}<.001 \\
<.001 \\
<.001 \\
<.001 \\
<.001\end{array}$ \\
\hline $\begin{array}{l}373559102314901 \\
373732099291201 \\
374535102110301 \\
374650100181901 \\
375129100532301\end{array}$ & $\begin{array}{l}<.04 \\
<.04 \\
<.04 \\
<.04 \\
<.04\end{array}$ & $\begin{array}{l}<.004 \\
<.004 \\
<.004 \\
<.004 \\
<.004\end{array}$ & $\begin{array}{l}<.05 \\
<.05 \\
<.05 \\
<.05 \\
<.05\end{array}$ & $\begin{array}{l}<.07 \\
<.07 \\
<.07 \\
<.07 \\
<.07\end{array}$ & $\begin{array}{l}<.002 \\
<.002 \\
<.002 \\
<.002 \\
<.002\end{array}$ & $\begin{array}{l}<.002 \\
\mathrm{E} .008 \\
<.002 \\
\mathrm{E} 1.9 \\
<.002\end{array}$ & $\begin{array}{l}<.06 \\
<.06 \\
<.06 \\
.15 \\
<.06\end{array}$ & $\begin{array}{l}<.07 \\
<.07 \\
<.07 \\
<.07 \\
<.07\end{array}$ & $\begin{array}{l}<.002 \\
<.002 \\
<.002 \\
<.002 \\
<.002\end{array}$ & $\begin{array}{l}<.10 \\
<.10 \\
<.10 \\
<.10 \\
<.10\end{array}$ & $\begin{array}{l}<.05 \\
<.05 \\
<.05 \\
<.05 \\
<.05\end{array}$ & $\begin{array}{l}<.001 \\
<.001 \\
<.001 \\
<.001 \\
<.001\end{array}$ \\
\hline $\begin{array}{l}375447099245001 \\
375828101111801 \\
380331100352801 \\
382947100443201 \\
383008101315601\end{array}$ & $\begin{array}{l}<.04 \\
<.04 \\
<.04 \\
<.04 \\
<.04\end{array}$ & $\begin{array}{l}<.004 \\
<.004 \\
<.004 \\
<.004 \\
<.004\end{array}$ & $\begin{array}{l}<.05 \\
<.05 \\
<.05 \\
<.05 \\
<.05\end{array}$ & $\begin{array}{l}<.07 \\
<.07 \\
<.07 \\
<.07 \\
<.07\end{array}$ & $\begin{array}{l}<.002 \\
<.002 \\
<.002 \\
<.002 \\
<.002\end{array}$ & $\begin{array}{l}\mathrm{E} .083 \\
<.002 \\
<.002 \\
<.002 \\
\mathrm{E} .052\end{array}$ & $\begin{array}{l}<.06 \\
<.06 \\
<.06 \\
<.06 \\
<.06\end{array}$ & $\begin{array}{l}<.07 \\
<.07 \\
<.07 \\
<.07 \\
<.07\end{array}$ & $\begin{array}{l}<.002 \\
<.002 \\
<.002 \\
<.002 \\
<.002\end{array}$ & $\begin{array}{l}<.10 \\
<.10 \\
<.10 \\
<.10 \\
<.10\end{array}$ & $\begin{array}{l}<.05 \\
<.05 \\
<.05 \\
<.05 \\
<.05\end{array}$ & $\begin{array}{l}<.001 \\
<.001 \\
<.001 \\
<.001 \\
<.001\end{array}$ \\
\hline $\begin{array}{l}383758101195801 \\
383919101040101 \\
385210100164501 \\
385904099522201 \\
390622101003201\end{array}$ & $\begin{array}{l}<.04 \\
<.04 \\
<.04 \\
<.04 \\
<.04\end{array}$ & $\begin{array}{l}<.004 \\
<.004 \\
<.004 \\
<.004 \\
<.004\end{array}$ & $\begin{array}{l}<.05 \\
<.05 \\
<.05 \\
<.05 \\
<.05\end{array}$ & $\begin{array}{l}<.07 \\
<.07 \\
<.07 \\
<.07 \\
<.07\end{array}$ & $\begin{array}{l}<.002 \\
<.002 \\
<.002 \\
<.002 \\
<.002\end{array}$ & $\begin{array}{l}\mathrm{E} .139 \\
\mathrm{E} .026 \\
<.002 \\
\mathrm{E} .605 \\
\mathrm{E} .132\end{array}$ & $\begin{array}{l}<.06 \\
<.06 \\
<.06 \\
<.06 \\
<.06\end{array}$ & $\begin{array}{l}<.07 \\
<.07 \\
<.07 \\
<.07 \\
<.07\end{array}$ & $\begin{array}{l}<.002 \\
<.002 \\
<.002 \\
<.002 \\
<.002\end{array}$ & $\begin{array}{l}<.10 \\
<.10 \\
<.10 \\
<.10 \\
<.10\end{array}$ & $\begin{array}{l}<.05 \\
<.05 \\
<.05 \\
<.05 \\
<.05\end{array}$ & $\begin{array}{l}<.001 \\
<.001 \\
<.001 \\
<.001 \\
<.001\end{array}$ \\
\hline $\begin{array}{l}390830102052001 \\
390838100411701 \\
391044100051001 \\
391921101385501\end{array}$ & $\begin{array}{l}<.04 \\
<.04 \\
<.04 \\
<.04\end{array}$ & $\begin{array}{l}<.004 \\
<.004 \\
<.004 \\
<.004\end{array}$ & $\begin{array}{l}<.05 \\
<.05 \\
<.05 \\
<.05\end{array}$ & $\begin{array}{l}<.07 \\
<.07 \\
<.07 \\
<.07\end{array}$ & $\begin{array}{l}<.002 \\
<.002 \\
<.002 \\
<.002\end{array}$ & $\begin{array}{l}<.002 \\
\mathrm{E} .003 \\
<.002 \\
\mathrm{E} .061\end{array}$ & $\begin{array}{l}<.06 \\
<.06 \\
<.06 \\
<.06\end{array}$ & $\begin{array}{l}<.07 \\
<.07 \\
<.07 \\
<.07\end{array}$ & $\begin{array}{l}<.002 \\
<.002 \\
<.002 \\
<.002\end{array}$ & $\begin{array}{c}<.10 \\
<.10 \\
-- \\
<.10\end{array}$ & $\begin{array}{l}<.05 \\
<.05 \\
<.05 \\
<.05\end{array}$ & $\begin{array}{l}<.001 \\
<.001 \\
<.001 \\
<.001\end{array}$ \\
\hline
\end{tabular}


Appendix 1. Water-quality data from 74 domestic water-supply wells completed in the central High Plains aquifer-Continued

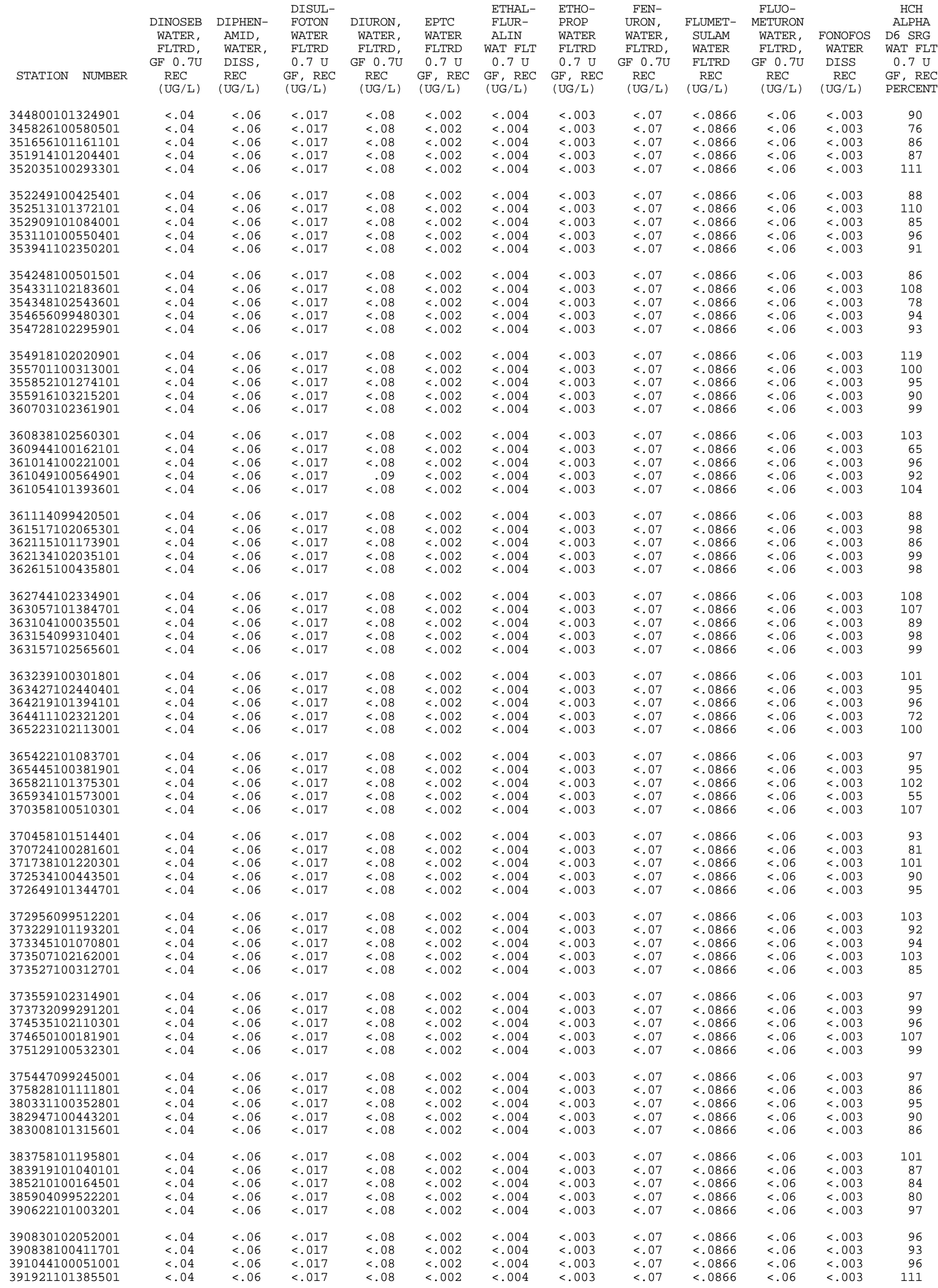




\begin{tabular}{|c|c|c|c|c|c|c|c|c|c|c|c|c|}
\hline STATION NUMBER & $\begin{array}{l}\text { HYDROXY } \\
\text { ATRA- } \\
\text { ZINE } \\
\text { WATER } \\
\text { FLTRD } \\
\text { REC } \\
\text { (UG/L) }\end{array}$ & $\begin{array}{l}\text { IMAZ- } \\
\text { AQUIN } \\
\text { WATER } \\
\text { FLTRD } \\
\text { REC } \\
\text { (UG/L) }\end{array}$ & $\begin{array}{l}\text { IMAZE- } \\
\text { THAPYR } \\
\text { WATER } \\
\text { FLTRD } \\
\text { REC } \\
\text { (UG/L) }\end{array}$ & $\begin{array}{l}\text { IMID- } \\
\text { ACLOP- } \\
\text { RID } \\
\text { WATER } \\
\text { FLTRD } \\
\text { REC } \\
\text { (UG/L) }\end{array}$ & $\begin{array}{l}\text { LINDANE } \\
\text { DIS- } \\
\text { SOLVED } \\
\text { (UG/L) }\end{array}$ & $\begin{array}{c}\text { LINURON } \\
\text { WATER, } \\
\text { FLTRD, } \\
\text { GF } 0.7 \mathrm{U} \\
\text { REC } \\
\text { (UG/L) }\end{array}$ & $\begin{array}{l}\text { LIN- } \\
\text { URON } \\
\text { WATER } \\
\text { FLTRD } \\
0.7 \text { U } \\
\text { GE, REC } \\
\text { (UG/L) }\end{array}$ & $\begin{array}{l}\text { MALA- } \\
\text { THION, } \\
\text { DIS- } \\
\text { SOLVED } \\
\text { (UG/L) }\end{array}$ & $\begin{array}{c}\text { MCPA, } \\
\text { WATER, } \\
\text { FLTRD, } \\
\text { GF } 0.7 \mathrm{U} \\
\text { REC } \\
\text { (UG/L) }\end{array}$ & $\begin{array}{c}\text { MCPB, } \\
\text { WATER, } \\
\text { FLTRD, } \\
\text { GF 0.7U } \\
\text { REC } \\
\text { (UG/L) }\end{array}$ & $\begin{array}{l}\text { METAL- } \\
\text { AXYL } \\
\text { WATER } \\
\text { FLTRD } \\
\text { REC } \\
\text { (UG/L) }\end{array}$ & $\begin{array}{c}\text { METHIO- } \\
\text { CARB, } \\
\text { WATER, } \\
\text { FLTRD, } \\
\text { GF } 0.7 \mathrm{U} \\
\text { REC } \\
\text { (UG/L) }\end{array}$ \\
\hline $\begin{array}{l}344800101324901 \\
345826100580501 \\
351656101161101 \\
351914101204401 \\
352035100293301\end{array}$ & $\begin{array}{l}<.193 \\
<.193 \\
<.193 \\
<.193 \\
<.193\end{array}$ & $\begin{array}{l}<.103 \\
<.103 \\
<.103 \\
<.103 \\
<.103\end{array}$ & $\begin{array}{l}<.088 \\
-- \\
<.088 \\
<.088 \\
<.088\end{array}$ & $\begin{array}{l}<.1060 \\
<.1060 \\
<.1060 \\
<.1060 \\
<.1060\end{array}$ & $\begin{array}{l}<.004 \\
<.004 \\
<.004 \\
<.004 \\
<.004\end{array}$ & $\begin{array}{l}<.07 \\
<.07 \\
<.07 \\
<.07 \\
<.07\end{array}$ & $\begin{array}{l}<.002 \\
<.002 \\
<.002 \\
<.002 \\
<.002\end{array}$ & $\begin{array}{l}<.005 \\
<.005 \\
<.005 \\
<.005 \\
<.005\end{array}$ & $\begin{array}{l}<.06 \\
<.06 \\
<.06 \\
<.06 \\
<.06\end{array}$ & $\begin{array}{l}<.06 \\
<.06 \\
<.06 \\
<.06 \\
<.06\end{array}$ & $\begin{array}{l}<.057 \\
<.057 \\
<.057 \\
<.057 \\
<.057\end{array}$ & $\begin{array}{l}<.08 \\
<.08 \\
<.08 \\
<.08 \\
<.08\end{array}$ \\
\hline $\begin{array}{l}352249100425401 \\
352513101372101 \\
352909101084001 \\
353110100550401 \\
353941102350201\end{array}$ & $\begin{array}{l}<.193 \\
<.193 \\
<.193 \\
<.193 \\
<.193\end{array}$ & $\begin{array}{l}<.103 \\
<.103 \\
<.103 \\
<.103 \\
<.103\end{array}$ & $\begin{array}{l}<.088 \\
<.088 \\
<.088 \\
-- \\
<.088\end{array}$ & $\begin{array}{l}<.1060 \\
<.1060 \\
<.1060 \\
<.1060 \\
<.1060\end{array}$ & $\begin{array}{l}<.004 \\
<.004 \\
<.004 \\
<.004 \\
<.004\end{array}$ & $\begin{array}{l}<.07 \\
<.07 \\
<.07 \\
<.07 \\
<.07\end{array}$ & $\begin{array}{l}<.002 \\
<.002 \\
<.002 \\
<.002 \\
<.002\end{array}$ & $\begin{array}{l}<.005 \\
<.005 \\
<.005 \\
<.005 \\
<.005\end{array}$ & $\begin{array}{l}<.06 \\
<.06 \\
<.06 \\
<.06 \\
<.06\end{array}$ & $\begin{array}{l}<.06 \\
<.06 \\
<.06 \\
<.06 \\
<.06\end{array}$ & $\begin{array}{l}<.057 \\
<.057 \\
<.057 \\
<.057 \\
<.057\end{array}$ & $\begin{array}{l}<.08 \\
<.08 \\
<.08 \\
<.08 \\
<.08\end{array}$ \\
\hline $\begin{array}{l}354248100501501 \\
354331102183601 \\
354348102543601 \\
354656099480301 \\
354728102295901\end{array}$ & $\begin{array}{l}<.193 \\
<.193 \\
<.193 \\
<.193 \\
<.193\end{array}$ & $\begin{array}{l}<.103 \\
<.103 \\
<.103 \\
<.103 \\
<.103\end{array}$ & $\begin{array}{l}<.088 \\
<.088 \\
<.088 \\
<.088 \\
<.088\end{array}$ & $\begin{array}{l}<.1060 \\
<.1060 \\
<.1060 \\
<.1060 \\
<.1060\end{array}$ & $\begin{array}{l}<.004 \\
<.004 \\
<.004 \\
<.004 \\
<.004\end{array}$ & $\begin{array}{l}<.07 \\
<.07 \\
<.07 \\
<.07 \\
<.07\end{array}$ & $\begin{array}{l}<.002 \\
<.002 \\
<.002 \\
<.002 \\
<.002\end{array}$ & $\begin{array}{l}<.005 \\
<.005 \\
<.005 \\
<.005 \\
<.005\end{array}$ & $\begin{array}{l}<.06 \\
<.06 \\
<.06 \\
<.06 \\
<.06\end{array}$ & $\begin{array}{l}<.06 \\
<.06 \\
<.06 \\
<.06 \\
<.06\end{array}$ & $\begin{array}{l}<.057 \\
<.057 \\
<.057 \\
<.057 \\
<.057\end{array}$ & $\begin{array}{l}<.08 \\
<.08 \\
<.08 \\
<.08 \\
<.08\end{array}$ \\
\hline $\begin{array}{l}354918102020901 \\
355701100313001 \\
355852101274101 \\
355916103215201 \\
360703102361901\end{array}$ & $\begin{array}{l}<.193 \\
<.193 \\
-- \\
<.193 \\
<.193\end{array}$ & $\begin{array}{l}<.103 \\
<.103 \\
<.103 \\
<.103 \\
<.103\end{array}$ & $\begin{array}{l}<.088 \\
<.088 \\
<.088 \\
<.088 \\
<.088\end{array}$ & $\begin{array}{l}<.1060 \\
<.1060 \\
<.1060 \\
<.1060 \\
<.1060\end{array}$ & $\begin{array}{l}<.004 \\
<.004 \\
<.004 \\
<.004 \\
<.004\end{array}$ & $\begin{array}{l}<.07 \\
<.07 \\
<.07 \\
<.07 \\
<.07\end{array}$ & $\begin{array}{l}<.002 \\
<.002 \\
<.002 \\
<.002 \\
<.002\end{array}$ & $\begin{array}{l}<.005 \\
<.005 \\
<.005 \\
<.005 \\
<.005\end{array}$ & $\begin{array}{l}<.06 \\
<.06 \\
<.06 \\
<.06 \\
<.06\end{array}$ & $\begin{array}{l}<.06 \\
<.06 \\
<.06 \\
<.06 \\
<.06\end{array}$ & $\begin{array}{l}<.057 \\
<.057 \\
<.057 \\
<.057 \\
<.057\end{array}$ & $\begin{array}{l}<.08 \\
<.08 \\
<.08 \\
<.08 \\
<.08\end{array}$ \\
\hline $\begin{array}{l}360838102560301 \\
360944100162101 \\
361014100221001 \\
361049100564901 \\
361054101393601\end{array}$ & $\begin{array}{l}<.193 \\
<.193 \\
<.193 \\
<.193 \\
<.193\end{array}$ & $\begin{array}{l}<.103 \\
<.103 \\
<.103 \\
<.103 \\
<.103\end{array}$ & $\begin{array}{l}<.088 \\
<.088 \\
<.088 \\
<.088 \\
<.088\end{array}$ & $\begin{array}{l}<.1060 \\
<.1060 \\
<.1060 \\
<.1060 \\
<.1060\end{array}$ & $\begin{array}{l}<.004 \\
<.004 \\
<.004 \\
<.004 \\
<.004\end{array}$ & $\begin{array}{l}<.07 \\
<.07 \\
<.07 \\
<.07 \\
<.07\end{array}$ & $\begin{array}{l}<.002 \\
<.002 \\
<.002 \\
<.002 \\
<.002\end{array}$ & $\begin{array}{l}<.005 \\
<.005 \\
<.005 \\
<.005 \\
<.005\end{array}$ & $\begin{array}{l}<.06 \\
<.06 \\
<.06 \\
<.06 \\
<.06\end{array}$ & $\begin{array}{l}<.06 \\
<.06 \\
<.06 \\
<.06 \\
<.06\end{array}$ & $\begin{array}{l}<.057 \\
<.057 \\
<.057 \\
<.057 \\
<.057\end{array}$ & $\begin{array}{l}<.08 \\
<.08 \\
<.08 \\
<.08 \\
<.08\end{array}$ \\
\hline $\begin{array}{l}361114099420501 \\
361517102065301 \\
362115101173901 \\
362134102035101 \\
362615100435801\end{array}$ & $\begin{array}{l}<.193 \\
<.193 \\
\mathrm{E} .325 \\
<.193 \\
<.193\end{array}$ & $\begin{array}{l}<.103 \\
<.103 \\
<.103 \\
<.103 \\
<.103\end{array}$ & $\begin{array}{l}<.088 \\
<.088 \\
<.088 \\
<.088 \\
<.088\end{array}$ & $\begin{array}{l}<.1060 \\
<.1060 \\
<.1060 \\
<.1060 \\
<.1060\end{array}$ & $\begin{array}{l}<.004 \\
<.004 \\
<.004 \\
<.004 \\
<.004\end{array}$ & $\begin{array}{l}<.07 \\
<.07 \\
<.07 \\
<.07 \\
<.07\end{array}$ & $\begin{array}{l}<.002 \\
<.002 \\
<.002 \\
<.002 \\
<.002\end{array}$ & $\begin{array}{l}<.005 \\
<.005 \\
<.005 \\
<.005 \\
<.005\end{array}$ & $\begin{array}{l}<.06 \\
<.06 \\
<.06 \\
<.06 \\
<.06\end{array}$ & $\begin{array}{l}<.06 \\
<.06 \\
<.06 \\
<.06 \\
<.06\end{array}$ & $\begin{array}{l}<.057 \\
<.057 \\
<.057 \\
<.057 \\
<.057\end{array}$ & $\begin{array}{l}<.08 \\
<.08 \\
<.08 \\
<.08 \\
<.08\end{array}$ \\
\hline $\begin{array}{l}362744102334901 \\
363057101384701 \\
363104100035501 \\
363154099310401 \\
363157102565601\end{array}$ & $\begin{array}{l}<.193 \\
<.193 \\
<.193 \\
<.193 \\
<.193\end{array}$ & $\begin{array}{l}<.103 \\
<.103 \\
<.103 \\
<.103 \\
<.103\end{array}$ & $\begin{array}{l}<.088 \\
<.088 \\
<.088 \\
<.088 \\
<.088\end{array}$ & $\begin{array}{l}<.1060 \\
<.1060 \\
<.1060 \\
<.1060 \\
<.1060\end{array}$ & $\begin{array}{l}<.004 \\
<.004 \\
<.004 \\
<.004 \\
<.004\end{array}$ & $\begin{array}{l}<.07 \\
<.07 \\
<.07 \\
<.07 \\
<.07\end{array}$ & $\begin{array}{l}<.002 \\
<.002 \\
<.002 \\
<.002 \\
<.002\end{array}$ & $\begin{array}{l}<.005 \\
<.005 \\
<.005 \\
<.005 \\
<.005\end{array}$ & $\begin{array}{l}<.06 \\
<.06 \\
<.06 \\
<.06 \\
<.06\end{array}$ & $\begin{array}{l}<.06 \\
<.06 \\
<.06 \\
<.06 \\
<.06\end{array}$ & $\begin{array}{l}<.057 \\
<.057 \\
<.057 \\
<.057 \\
<.057\end{array}$ & $\begin{array}{l}<.08 \\
<.08 \\
<.08 \\
<.08 \\
<.08\end{array}$ \\
\hline $\begin{array}{l}363239100301801 \\
363427102440401 \\
364219101394101 \\
364411102321201 \\
365223102113001\end{array}$ & $\begin{aligned} & -- \\
< & .193 \\
< & .193 \\
< & .193 \\
< & .193\end{aligned}$ & $\begin{array}{l}<.103 \\
<.103 \\
<.103 \\
<.103 \\
<.103\end{array}$ & $\begin{array}{l}<.088 \\
<.088 \\
<.088 \\
<.088 \\
<.088\end{array}$ & $\begin{array}{l}<.1060 \\
<.1060 \\
<.1060 \\
<.1060 \\
<.1060\end{array}$ & $\begin{array}{l}<.004 \\
<.004 \\
<.004 \\
<.004 \\
<.004\end{array}$ & $\begin{array}{l}<.07 \\
<.07 \\
<.07 \\
<.07 \\
<.07\end{array}$ & $\begin{array}{l}<.002 \\
<.002 \\
<.002 \\
<.002 \\
<.002\end{array}$ & $\begin{array}{l}<.005 \\
<.005 \\
<.005 \\
<.005 \\
<.005\end{array}$ & $\begin{array}{l}<.06 \\
<.06 \\
<.06 \\
<.06 \\
<.06\end{array}$ & $\begin{array}{l}<.06 \\
<.06 \\
<.06 \\
<.06 \\
<.06\end{array}$ & $\begin{array}{l}<.057 \\
<.057 \\
<.057 \\
<.057 \\
<.057\end{array}$ & $\begin{array}{l}<.08 \\
<.08 \\
<.08 \\
<.08 \\
<.08\end{array}$ \\
\hline $\begin{array}{l}365422101083701 \\
365445100381901 \\
365821101375301 \\
365934101573001 \\
370358100510301\end{array}$ & $\begin{array}{l}<.193 \\
<.193 \\
<.193 \\
<.193 \\
<.193\end{array}$ & $\begin{array}{l}<.103 \\
<.103 \\
<.103 \\
<.103 \\
<.103\end{array}$ & $\begin{array}{l}<.088 \\
<.088 \\
<.088 \\
<.088 \\
<.088\end{array}$ & $\begin{array}{l}<.1060 \\
<.1060 \\
<.1060 \\
<.1060 \\
<.1060\end{array}$ & $\begin{array}{l}<.004 \\
<.004 \\
<.004 \\
<.004 \\
<.004\end{array}$ & $\begin{array}{l}<.07 \\
<.07 \\
<.07 \\
<.07 \\
<.07\end{array}$ & $\begin{array}{l}<.002 \\
<.002 \\
<.002 \\
<.002 \\
<.002\end{array}$ & $\begin{array}{l}<.005 \\
<.005 \\
<.005 \\
<.005 \\
<.005\end{array}$ & $\begin{array}{l}<.06 \\
<.06 \\
<.06 \\
<.06 \\
<.06\end{array}$ & $\begin{array}{l}<.06 \\
<.06 \\
<.06 \\
<.06 \\
<.06\end{array}$ & $\begin{array}{l}<.057 \\
<.057 \\
<.057 \\
<.057 \\
<.057\end{array}$ & $\begin{array}{l}<.08 \\
<.08 \\
<.08 \\
<.08 \\
<.08\end{array}$ \\
\hline $\begin{array}{l}370458101514401 \\
370724100281601 \\
371738101220301 \\
372534100443501 \\
372649101344701\end{array}$ & $\begin{array}{l}<.193 \\
<.193 \\
<.193 \\
<.193 \\
<.193\end{array}$ & $\begin{array}{l}<.103 \\
<.103 \\
<.103 \\
<.103 \\
<.103\end{array}$ & $\begin{array}{l}<.088 \\
<.088 \\
<.088 \\
<.088 \\
<.088\end{array}$ & $\begin{array}{l}<.1060 \\
<.1060 \\
<.1060 \\
<.1060 \\
<.1060\end{array}$ & $\begin{array}{l}<.004 \\
<.004 \\
<.004 \\
<.004 \\
<.004\end{array}$ & $\begin{array}{l}<.07 \\
<.07 \\
<.07 \\
<.07 \\
<.07\end{array}$ & $\begin{array}{l}<.002 \\
<.002 \\
<.002 \\
<.002 \\
<.002\end{array}$ & $\begin{array}{l}<.005 \\
<.005 \\
<.005 \\
<.005 \\
<.005\end{array}$ & $\begin{array}{l}<.06 \\
<.06 \\
<.06 \\
<.06 \\
<.06\end{array}$ & $\begin{array}{l}<.06 \\
<.06 \\
<.06 \\
<.06 \\
<.06\end{array}$ & $\begin{array}{l}<.057 \\
<.057 \\
<.057 \\
<.057 \\
<.057\end{array}$ & $\begin{array}{l}<.08 \\
<.08 \\
<.08 \\
<.08 \\
<.08\end{array}$ \\
\hline $\begin{array}{l}372956099512201 \\
373229101193201 \\
373345101070801 \\
373507102162001 \\
373527100312701\end{array}$ & $\begin{array}{l}<.193 \\
<.193 \\
-- \\
<.193 \\
<.193\end{array}$ & $\begin{array}{l}<.103 \\
<.103 \\
<.103 \\
<.103 \\
<.103\end{array}$ & $\begin{array}{l}<.088 \\
<.088 \\
<.088 \\
<.088 \\
<.088\end{array}$ & $\begin{array}{l}<.1060 \\
<.1060 \\
<.1060 \\
<.1060 \\
<.1060\end{array}$ & $\begin{array}{l}<.004 \\
<.004 \\
<.004 \\
<.004 \\
<.004\end{array}$ & $\begin{array}{l}<.07 \\
<.07 \\
<.07 \\
<.07 \\
<.07\end{array}$ & $\begin{array}{l}<.002 \\
<.002 \\
<.002 \\
<.002 \\
<.002\end{array}$ & $\begin{array}{l}<.005 \\
<.005 \\
<.005 \\
<.005 \\
<.005\end{array}$ & $\begin{array}{l}<.06 \\
<.06 \\
<.06 \\
<.06 \\
<.06\end{array}$ & $\begin{array}{l}<.06 \\
<.06 \\
<.06 \\
<.06 \\
<.06\end{array}$ & $\begin{array}{l}<.057 \\
<.057 \\
<.057 \\
<.057 \\
<.057\end{array}$ & $\begin{array}{l}<.08 \\
<.08 \\
<.08 \\
<.08 \\
<.08\end{array}$ \\
\hline $\begin{array}{l}373559102314901 \\
373732099291201 \\
374535102110301 \\
374650100181901 \\
375129100532301\end{array}$ & $\begin{array}{l}<.193 \\
<.193 \\
<.193 \\
<.193 \\
<.193\end{array}$ & $\begin{array}{l}<.103 \\
<.103 \\
<.103 \\
<.103 \\
<.103\end{array}$ & $\begin{array}{l}<.088 \\
<.088 \\
<.088 \\
<.088 \\
<.088\end{array}$ & $\begin{array}{l}<.1060 \\
<.1060 \\
<.1060 \\
<.1060 \\
<.1060\end{array}$ & $\begin{array}{l}<.004 \\
<.004 \\
<.004 \\
<.004 \\
<.004\end{array}$ & $\begin{array}{l}<.07 \\
<.07 \\
<.07 \\
<.07 \\
<.07\end{array}$ & $\begin{array}{l}<.002 \\
<.002 \\
<.002 \\
<.002 \\
<.002\end{array}$ & $\begin{array}{l}<.005 \\
<.005 \\
<.005 \\
<.005 \\
<.005\end{array}$ & $\begin{array}{l}<.06 \\
<.06 \\
<.06 \\
<.06 \\
<.06\end{array}$ & $\begin{array}{l}<.06 \\
<.06 \\
<.06 \\
<.06 \\
<.06\end{array}$ & $\begin{array}{l}<.057 \\
<.057 \\
<.057 \\
<.057 \\
<.057\end{array}$ & $\begin{array}{l}<.08 \\
<.08 \\
<.08 \\
<.08 \\
<.08\end{array}$ \\
\hline $\begin{array}{l}375447099245001 \\
375828101111801 \\
380331100352801 \\
382947100443201 \\
383008101315601\end{array}$ & $\begin{array}{l}<.193 \\
<.193 \\
<.193 \\
<.193 \\
<.193\end{array}$ & $\begin{array}{l}<.103 \\
<.103 \\
<.103 \\
<.103 \\
<.103\end{array}$ & $\begin{array}{l}<.088 \\
<.088 \\
<.088 \\
<.088 \\
<.088\end{array}$ & $\begin{array}{l}<.1060 \\
<.1060 \\
<.1060 \\
<.1060 \\
<.1060\end{array}$ & $\begin{array}{l}<.004 \\
<.004 \\
<.004 \\
<.004 \\
<.004\end{array}$ & $\begin{array}{l}<.07 \\
<.07 \\
<.07 \\
<.07 \\
<.07\end{array}$ & $\begin{array}{l}<.002 \\
<.002 \\
<.002 \\
<.002 \\
<.002\end{array}$ & $\begin{array}{l}<.005 \\
<.005 \\
<.005 \\
<.005 \\
<.005\end{array}$ & $\begin{array}{l}<.06 \\
<.06 \\
<.06 \\
<.06 \\
<.06\end{array}$ & $\begin{array}{l}<.06 \\
<.06 \\
<.06 \\
<.06 \\
<.06\end{array}$ & $\begin{array}{l}<.057 \\
<.057 \\
<.057 \\
<.057 \\
<.057\end{array}$ & $\begin{array}{l}<.08 \\
<.08 \\
<.08 \\
<.08 \\
<.08\end{array}$ \\
\hline $\begin{array}{l}383758101195801 \\
383919101040101 \\
385210100164501 \\
385904099522201 \\
390622101003201\end{array}$ & $\begin{array}{l}<.193 \\
<.193 \\
<.193 \\
<.193 \\
<.193\end{array}$ & $\begin{array}{l}<.103 \\
<.103 \\
<.103 \\
<.103 \\
<.103\end{array}$ & $\begin{array}{l}<.088 \\
<.088 \\
<.088 \\
<.088 \\
<.088\end{array}$ & $\begin{array}{l}<.1060 \\
<.1060 \\
<.1060 \\
<.1060 \\
<.1060\end{array}$ & $\begin{array}{l}<.004 \\
<.004 \\
<.004 \\
<.004 \\
<.004\end{array}$ & $\begin{array}{l}<.07 \\
<.07 \\
<.07 \\
<.07 \\
<.07\end{array}$ & $\begin{array}{l}<.002 \\
<.002 \\
<.002 \\
<.002 \\
<.002\end{array}$ & $\begin{array}{l}<.005 \\
<.005 \\
<.005 \\
<.005 \\
<.005\end{array}$ & $\begin{array}{l}<.06 \\
<.06 \\
<.06 \\
<.06 \\
<.06\end{array}$ & $\begin{array}{l}<.06 \\
<.06 \\
<.06 \\
<.06 \\
<.06\end{array}$ & $\begin{array}{l}<.057 \\
<.057 \\
<.057 \\
<.057 \\
<.057\end{array}$ & $\begin{array}{l}<.08 \\
<.08 \\
<.08 \\
<.08 \\
<.08\end{array}$ \\
\hline $\begin{array}{l}390830102052001 \\
390838100411701 \\
391044100051001 \\
391921101385501\end{array}$ & $\begin{array}{l}<.193 \\
<.193 \\
<.193 \\
<.193\end{array}$ & $\begin{array}{l}<.103 \\
<.103 \\
<.103 \\
<.103\end{array}$ & $\begin{array}{l}<.088 \\
<.088 \\
<.088 \\
<.088\end{array}$ & $\begin{array}{l}<.1060 \\
<.1060 \\
<.1060 \\
<.1060\end{array}$ & $\begin{array}{l}<.004 \\
<.004 \\
<.004 \\
<.004\end{array}$ & $\begin{array}{l}<.07 \\
<.07 \\
<.07 \\
<.07\end{array}$ & $\begin{array}{l}<.002 \\
<.002 \\
<.002 \\
<.002\end{array}$ & $\begin{array}{l}<.005 \\
<.005 \\
<.005 \\
.008\end{array}$ & $\begin{array}{l}<.06 \\
<.06 \\
<.06 \\
<.06\end{array}$ & $\begin{array}{l}<.06 \\
<.06 \\
<.06 \\
<.06\end{array}$ & $\begin{array}{l}<.057 \\
<.057 \\
<.057 \\
<.057\end{array}$ & $\begin{array}{l}<.08 \\
<.08 \\
<.08 \\
<.08\end{array}$ \\
\hline
\end{tabular}




\begin{tabular}{|c|c|c|c|c|c|c|c|c|c|c|c|c|}
\hline STATION NUMBER & $\begin{array}{l}\text { METH- } \\
\text { OMYL } \\
\text { OXIME } \\
\text { WATER } \\
\text { FLTRD } \\
\text { REC } \\
\text { (UG/L) }\end{array}$ & $\begin{array}{c}\text { METH- } \\
\text { OMYL, } \\
\text { WATER, } \\
\text { FLTRD, } \\
\text { GF 0.7U } \\
\text { REC } \\
\text { (UG/L) }\end{array}$ & $\begin{array}{l}\text { METHYL } \\
\text { AZIN- } \\
\text { PHOS } \\
\text { WAT FLT } \\
0.7 \text { U } \\
\text { GE, REC } \\
\text { (UG/L) }\end{array}$ & $\begin{array}{c}\text { METHYL } \\
\text { PARA- } \\
\text { THION } \\
\text { WAT FLT } \\
0.7 \text { U } \\
\text { GE, REC } \\
(\text { UG/L) }\end{array}$ & $\begin{array}{c}\text { METOLA- } \\
\text { CHLOR } \\
\text { ESA } \\
\text { FLTRD } \\
0.7 \text { UM } \\
\text { GF REC } \\
\text { (UG/L) }\end{array}$ & $\begin{array}{c}\text { METOLA- } \\
\text { CHLOR } \\
\text { OA } \\
\text { FLTRD } \\
0.7 \text { UM } \\
\text { GF REC } \\
\text { (UG/L) }\end{array}$ & $\begin{array}{l}\text { METO- } \\
\text { LACHLOR } \\
\text { WATER } \\
\text { DISSOLV } \\
\text { (UG/L) }\end{array}$ & $\begin{array}{l}\text { METRI- } \\
\text { BUZIN } \\
\text { SENCOR } \\
\text { WATER } \\
\text { DISSOLV } \\
\text { (UG/L) }\end{array}$ & $\begin{array}{c}\text { MET- } \\
\text { SUL- } \\
\text { FURON } \\
\text { METHYL } \\
\text { WAT FLT } \\
\text { REC } \\
\text { (UG/L) }\end{array}$ & $\begin{array}{c}\text { MOL- } \\
\text { INATE } \\
\text { WATER } \\
\text { FLTRD } \\
0.7 \text { U } \\
\text { GE, REC } \\
\text { (UG/L) }\end{array}$ & $\begin{array}{c}\text { NAPROP- } \\
\text { AMIDE } \\
\text { WATER } \\
\text { FLTRD } \\
0.7 \mathrm{U} \\
\text { GE, REC } \\
\text { (UG/L) }\end{array}$ & $\begin{array}{c}\text { NEB- } \\
\text { URON, } \\
\text { WATER, } \\
\text { FLTRD, } \\
\text { GF } 0.7 \mathrm{U} \\
\text { REC } \\
\text { (UG/L) }\end{array}$ \\
\hline $\begin{array}{l}344800101324901 \\
345826100580501 \\
351656101161101 \\
351914101204401 \\
352035100293301\end{array}$ & $\begin{array}{l}<.0102 \\
<.0102 \\
<.0102 \\
<.0102 \\
<.0102\end{array}$ & $\begin{array}{l}<.08 \\
<.08 \\
<.08 \\
<.08 \\
<.08\end{array}$ & $\begin{array}{l}<.001 \\
<.001 \\
<.001 \\
<.001 \\
<.001\end{array}$ & $\begin{array}{l}<.006 \\
<.006 \\
<.006 \\
<.006 \\
<.006\end{array}$ & $\begin{array}{l}<.05 \\
<.05 \\
<.05 \\
<.05 \\
<.05\end{array}$ & $\begin{array}{l}<.05 \\
<.05 \\
<.05 \\
<.05 \\
<.05\end{array}$ & $\begin{array}{l}<.002 \\
<.002 \\
<.002 \\
<.002 \\
<.002\end{array}$ & $\begin{array}{l}<.004 \\
<.004 \\
<.004 \\
<.004 \\
<.004\end{array}$ & $\begin{array}{l}<.1138 \\
<.1138 \\
<.1138 \\
<.1138 \\
<.1138\end{array}$ & $\begin{array}{l}<.004 \\
<.004 \\
<.004 \\
<.004 \\
<.004\end{array}$ & $\begin{array}{l}<.003 \\
<.003 \\
<.003 \\
<.003 \\
<.003\end{array}$ & $\begin{array}{l}<.07 \\
<.07 \\
<.07 \\
<.07 \\
<.07\end{array}$ \\
\hline $\begin{array}{l}352249100425401 \\
352513101372101 \\
352909101084001 \\
353110100550401 \\
353941102350201\end{array}$ & $\begin{array}{l}<.0102 \\
<.0102 \\
<.0102 \\
<.0102 \\
<.0102\end{array}$ & $\begin{array}{l}<.08 \\
<.08 \\
<.08 \\
<.08 \\
<.08\end{array}$ & $\begin{array}{l}<.001 \\
<.001 \\
<.001 \\
<.001 \\
<.001\end{array}$ & $\begin{array}{l}<.006 \\
<.006 \\
<.006 \\
<.006 \\
<.006\end{array}$ & $\begin{array}{l}<.05 \\
<.05 \\
<.05 \\
<.05 \\
<.05\end{array}$ & $\begin{array}{l}<.05 \\
<.05 \\
<.05 \\
<.05 \\
<.05\end{array}$ & $\begin{array}{l}<.002 \\
<.002 \\
<.002 \\
<.002 \\
<.002\end{array}$ & $\begin{array}{l}<.004 \\
<.004 \\
<.004 \\
<.004 \\
<.004\end{array}$ & $\begin{array}{l}<.1138 \\
<.1138 \\
<.1138 \\
<.1138 \\
<.1138\end{array}$ & $\begin{array}{l}<.004 \\
<.004 \\
<.004 \\
<.004 \\
<.004\end{array}$ & $\begin{array}{l}<.003 \\
<.003 \\
<.003 \\
<.003 \\
<.003\end{array}$ & $\begin{array}{l}<.07 \\
<.07 \\
<.07 \\
<.07 \\
<.07\end{array}$ \\
\hline $\begin{array}{l}354248100501501 \\
354331102183601 \\
354348102543601 \\
354656099480301 \\
354728102295901\end{array}$ & $\begin{array}{l}<.0102 \\
<.0102 \\
<.0102 \\
<.0102 \\
<.0102\end{array}$ & $\begin{array}{l}<.08 \\
<.08 \\
<.08 \\
<.08 \\
<.08\end{array}$ & $\begin{array}{l}<.001 \\
<.001 \\
<.001 \\
<.001 \\
<.001\end{array}$ & $\begin{array}{l}<.006 \\
<.006 \\
<.006 \\
<.006 \\
<.006\end{array}$ & $\begin{array}{l}<.05 \\
<.05 \\
<.05 \\
<.05 \\
<.05\end{array}$ & $\begin{array}{l}<.05 \\
<.05 \\
<.05 \\
<.05 \\
<.05\end{array}$ & $\begin{array}{l}<.002 \\
<.002 \\
<.002 \\
<.002 \\
<.002\end{array}$ & $\begin{array}{l}<.004 \\
<.004 \\
<.004 \\
<.004 \\
<.004\end{array}$ & $\begin{array}{l}<.1138 \\
<.1138 \\
<.1138 \\
<.1138 \\
<.1138\end{array}$ & $\begin{array}{l}<.004 \\
<.004 \\
<.004 \\
<.004 \\
<.004\end{array}$ & $\begin{array}{l}<.003 \\
<.003 \\
<.003 \\
<.003 \\
<.003\end{array}$ & $\begin{array}{l}<.07 \\
<.07 \\
<.07 \\
<.07 \\
<.07\end{array}$ \\
\hline $\begin{array}{l}354918102020901 \\
355701100313001 \\
355852101274101 \\
355916103215201 \\
360703102361901\end{array}$ & $\begin{array}{l}<.0102 \\
<.0102 \\
<.0102 \\
<.0102 \\
<.0102\end{array}$ & $\begin{array}{l}<.08 \\
<.08 \\
<.08 \\
<.08 \\
<.08\end{array}$ & $\begin{array}{l}<.007 \\
<.001 \\
<.001 \\
<.001 \\
<.001\end{array}$ & $\begin{array}{l}<.006 \\
<.006 \\
<.006 \\
<.006 \\
<.006\end{array}$ & $\begin{array}{l}<.05 \\
<.05 \\
<.05 \\
<.05 \\
<.05\end{array}$ & $\begin{array}{l}<.05 \\
<.05 \\
<.05 \\
<.05 \\
<.05\end{array}$ & $\begin{array}{l}.029 \\
<.002 \\
<.002 \\
<.002 \\
<.002\end{array}$ & $\begin{array}{l}<.004 \\
<.004 \\
<.004 \\
<.004 \\
<.004\end{array}$ & $\begin{array}{l}<.1138 \\
<.1138 \\
<.1138 \\
<.1138 \\
<.1138\end{array}$ & $\begin{array}{l}<.004 \\
<.004 \\
<.004 \\
<.004 \\
<.004\end{array}$ & $\begin{array}{l}<.003 \\
<.003 \\
<.003 \\
<.003 \\
<.003\end{array}$ & $\begin{array}{l}<.07 \\
<.07 \\
<.07 \\
<.07 \\
<.07\end{array}$ \\
\hline $\begin{array}{l}360838102560301 \\
360944100162101 \\
361014100221001 \\
361049100564901 \\
361054101393601\end{array}$ & $\begin{array}{l}<.0102 \\
<.0102 \\
<.0102 \\
<.0102 \\
<.0102\end{array}$ & $\begin{array}{l}<.08 \\
<.08 \\
<.08 \\
<.08 \\
<.08\end{array}$ & $\begin{array}{l}<.001 \\
<.001 \\
<.001 \\
<.001 \\
<.001\end{array}$ & $\begin{array}{l}<.006 \\
<.006 \\
<.006 \\
<.006 \\
<.006\end{array}$ & $\begin{array}{l}<.05 \\
<.05 \\
<.05 \\
<.05 \\
<.05\end{array}$ & $\begin{array}{l}<.05 \\
<.05 \\
<.05 \\
<.05 \\
<.05\end{array}$ & $\begin{array}{l}<.002 \\
<.002 \\
<.002 \\
<.002 \\
<.002\end{array}$ & $\begin{array}{l}<.004 \\
<.004 \\
<.004 \\
<.004 \\
<.004\end{array}$ & $\begin{array}{l}<.1138 \\
<.1138 \\
<.1138 \\
<.1138 \\
<.1138\end{array}$ & $\begin{array}{l}<.004 \\
<.004 \\
<.004 \\
<.004 \\
<.004\end{array}$ & $\begin{array}{l}<.003 \\
<.003 \\
<.003 \\
<.003 \\
<.003\end{array}$ & $\begin{array}{l}<.07 \\
<.07 \\
<.07 \\
<.07 \\
<.07\end{array}$ \\
\hline $\begin{array}{l}361114099420501 \\
361517102065301 \\
362115101173901 \\
362134102035101 \\
362615100435801\end{array}$ & $\begin{array}{l}<.0102 \\
<.0102 \\
<.0102 \\
<.0102 \\
<.0102\end{array}$ & $\begin{array}{l}<.08 \\
<.08 \\
<.08 \\
<.08 \\
<.08\end{array}$ & $\begin{array}{l}<.001 \\
<.001 \\
<.001 \\
<.001 \\
<.001\end{array}$ & $\begin{array}{l}<.006 \\
<.006 \\
<.006 \\
<.006 \\
<.006\end{array}$ & $\begin{array}{l}<.05 \\
<.05 \\
-- \\
<.05 \\
<.05\end{array}$ & $\begin{array}{l}<.05 \\
<.05 \\
-- \\
<.05 \\
<.05\end{array}$ & $\begin{array}{l}<.002 \\
<.002 \\
<.002 \\
<.002 \\
<.002\end{array}$ & $\begin{array}{l}<.004 \\
<.004 \\
<.004 \\
<.004 \\
<.004\end{array}$ & $\begin{array}{l}<.1138 \\
<.1138 \\
<.1138 \\
<.1138 \\
<.1138\end{array}$ & $\begin{array}{l}<.004 \\
<.004 \\
<.004 \\
<.004 \\
<.004\end{array}$ & $\begin{array}{l}<.003 \\
<.003 \\
<.003 \\
<.003 \\
<.003\end{array}$ & $\begin{array}{l}<.07 \\
<.07 \\
<.07 \\
<.07 \\
<.07\end{array}$ \\
\hline $\begin{array}{l}362744102334901 \\
363057101384701 \\
363104100035501 \\
363154099310401 \\
363157102565601\end{array}$ & $\begin{array}{l}<.0102 \\
<.0102 \\
<.0102 \\
<.0102 \\
<.0102\end{array}$ & $\begin{array}{l}<.08 \\
<.08 \\
<.08 \\
<.08 \\
<.08\end{array}$ & $\begin{array}{l}<.001 \\
<.001 \\
<.001 \\
<.001 \\
<.001\end{array}$ & $\begin{array}{l}<.006 \\
<.006 \\
<.006 \\
<.006 \\
<.006\end{array}$ & $\begin{array}{l}<.05 \\
<.05 \\
<.05 \\
<.05 \\
<.05\end{array}$ & $\begin{array}{l}<.05 \\
<.05 \\
<.05 \\
<.05 \\
<.05\end{array}$ & $\begin{array}{l}<.002 \\
<.002 \\
<.002 \\
<.002 \\
<.002\end{array}$ & $\begin{array}{l}<.004 \\
<.004 \\
<.004 \\
<.004 \\
<.004\end{array}$ & $\begin{array}{l}<.1138 \\
<.1138 \\
<.1138 \\
<.1138 \\
<.1138\end{array}$ & $\begin{array}{l}<.004 \\
<.004 \\
<.004 \\
<.004 \\
<.004\end{array}$ & $\begin{array}{l}<.003 \\
<.003 \\
<.003 \\
<.003 \\
<.003\end{array}$ & $\begin{array}{l}<.07 \\
<.07 \\
<.07 \\
<.07 \\
<.07\end{array}$ \\
\hline $\begin{array}{l}363239100301801 \\
363427102440401 \\
364219101394101 \\
364411102321201 \\
365223102113001\end{array}$ & $\begin{array}{l}<.0102 \\
<.0102 \\
<.0102 \\
<.0102 \\
<.0102\end{array}$ & $\begin{array}{l}<.08 \\
<.08 \\
<.08 \\
<.08 \\
<.08\end{array}$ & $\begin{array}{l}<.001 \\
<.001 \\
<.001 \\
<.001 \\
<.001\end{array}$ & $\begin{array}{l}<.006 \\
<.006 \\
<.006 \\
<.006 \\
<.006\end{array}$ & $\begin{array}{l}<.05 \\
<.05 \\
<.05 \\
<.05 \\
<.05\end{array}$ & $\begin{array}{l}<.05 \\
<.05 \\
<.05 \\
<.05 \\
<.05\end{array}$ & $\begin{array}{l}<.002 \\
<.002 \\
<.002 \\
<.002 \\
<.002\end{array}$ & $\begin{array}{l}<.004 \\
<.004 \\
<.004 \\
<.004 \\
<.004\end{array}$ & $\begin{array}{l}<.1138 \\
<.1138 \\
<.1138 \\
<.1138 \\
<.1138\end{array}$ & $\begin{array}{l}<.004 \\
<.004 \\
<.004 \\
<.004 \\
<.004\end{array}$ & $\begin{array}{l}<.003 \\
<.003 \\
<.003 \\
<.003 \\
<.003\end{array}$ & $\begin{array}{l}<.07 \\
<.07 \\
<.07 \\
<.07 \\
<.07\end{array}$ \\
\hline $\begin{array}{l}365422101083701 \\
365445100381901 \\
365821101375301 \\
365934101573001 \\
370358100510301\end{array}$ & $\begin{array}{l}<.0102 \\
<.0102 \\
<.0102 \\
<.0102 \\
<.0102\end{array}$ & $\begin{array}{l}<.08 \\
<.08 \\
<.08 \\
<.08 \\
<.08\end{array}$ & $\begin{array}{l}<.001 \\
<.001 \\
<.001 \\
<.001 \\
<.001\end{array}$ & $\begin{array}{l}<.006 \\
<.006 \\
<.006 \\
<.006 \\
<.006\end{array}$ & $\begin{array}{l}<.05 \\
<.05 \\
<.05 \\
<.05 \\
<.05\end{array}$ & $\begin{array}{l}<.05 \\
<.05 \\
<.05 \\
<.05 \\
<.05\end{array}$ & $\begin{array}{l}<.002 \\
<.002 \\
<.002 \\
<.002 \\
<.002\end{array}$ & $\begin{array}{l}<.004 \\
<.004 \\
<.004 \\
<.004 \\
<.004\end{array}$ & $\begin{array}{l}<.1138 \\
<.1138 \\
<.1138 \\
<.1138 \\
<.1138\end{array}$ & $\begin{array}{l}<.004 \\
<.004 \\
<.004 \\
<.004 \\
<.004\end{array}$ & $\begin{array}{l}<.003 \\
<.003 \\
<.003 \\
<.003 \\
<.003\end{array}$ & $\begin{array}{l}<.07 \\
<.07 \\
<.07 \\
<.07 \\
<.07\end{array}$ \\
\hline $\begin{array}{l}370458101514401 \\
370724100281601 \\
371738101220301 \\
372534100443501 \\
372649101344701\end{array}$ & $\begin{array}{l}<.0102 \\
<.0102 \\
<.0102 \\
<.0102 \\
<.0102\end{array}$ & $\begin{array}{l}<.08 \\
<.08 \\
<.08 \\
<.08 \\
<.08\end{array}$ & $\begin{array}{l}<.001 \\
<.001 \\
<.001 \\
<.001 \\
<.001\end{array}$ & $\begin{array}{l}<.006 \\
<.006 \\
<.006 \\
<.006 \\
<.006\end{array}$ & $\begin{array}{l}<.05 \\
<.05 \\
<.05 \\
<.05 \\
<.05\end{array}$ & $\begin{array}{l}<.05 \\
<.05 \\
<.05 \\
<.05 \\
<.05\end{array}$ & $\begin{array}{l}<.002 \\
<.002 \\
<.002 \\
<.002 \\
<.002\end{array}$ & $\begin{array}{l}<.004 \\
<.004 \\
<.004 \\
<.004 \\
<.004\end{array}$ & $\begin{array}{l}<.1138 \\
<.1138 \\
<.1138 \\
<.1138 \\
<.1138\end{array}$ & $\begin{array}{l}<.004 \\
<.004 \\
<.004 \\
<.004 \\
<.004\end{array}$ & $\begin{array}{l}<.003 \\
<.003 \\
<.003 \\
<.003 \\
<.003\end{array}$ & $\begin{array}{l}<.07 \\
<.07 \\
<.07 \\
<.07 \\
<.07\end{array}$ \\
\hline $\begin{array}{l}372956099512201 \\
373229101193201 \\
373345101070801 \\
373507102162001 \\
373527100312701\end{array}$ & $\begin{array}{l}<.0102 \\
<.0102 \\
<.0102 \\
<.0102 \\
<.0102\end{array}$ & $\begin{array}{l}<.08 \\
<.08 \\
<.08 \\
<.08 \\
<.08\end{array}$ & $\begin{array}{l}<.001 \\
<.001 \\
<.001 \\
<.001 \\
<.001\end{array}$ & $\begin{array}{l}<.006 \\
<.006 \\
<.006 \\
<.006 \\
<.006\end{array}$ & $\begin{array}{l}<.05 \\
<.05 \\
<.05 \\
<.05 \\
<.05\end{array}$ & $\begin{array}{l}<.05 \\
<.05 \\
<.05 \\
<.05 \\
<.05\end{array}$ & $\begin{array}{l}<.002 \\
<.002 \\
<.002 \\
<.002 \\
<.002\end{array}$ & $\begin{array}{l}<.004 \\
<.004 \\
<.004 \\
<.004 \\
<.004\end{array}$ & $\begin{array}{l}<.1138 \\
<.1138 \\
<.1138 \\
<.1138 \\
<.1138\end{array}$ & $\begin{array}{l}<.004 \\
<.004 \\
<.004 \\
<.004 \\
<.004\end{array}$ & $\begin{array}{l}<.003 \\
<.003 \\
<.003 \\
<.003 \\
<.003\end{array}$ & $\begin{array}{l}<.07 \\
<.07 \\
<.07 \\
<.07 \\
<.07\end{array}$ \\
\hline $\begin{array}{l}373559102314901 \\
373732099291201 \\
374535102110301 \\
374650100181901 \\
375129100532301\end{array}$ & $\begin{array}{l}<.0102 \\
<.0102 \\
<.0102 \\
<.0102 \\
<.0102\end{array}$ & $\begin{array}{l}<.08 \\
<.08 \\
<.08 \\
<.08 \\
<.08\end{array}$ & $\begin{array}{l}<.001 \\
<.001 \\
<.001 \\
<.001 \\
<.001\end{array}$ & $\begin{array}{l}<.006 \\
<.006 \\
<.006 \\
<.006 \\
<.006\end{array}$ & $\begin{array}{l}<.05 \\
<.05 \\
<.05 \\
1.94 \\
<.05\end{array}$ & $\begin{array}{l}<.05 \\
<.05 \\
<.05 \\
.25 \\
<.05\end{array}$ & $\begin{array}{l}<.002 \\
<.002 \\
<.002 \\
\mathrm{E} .003 \\
<.002\end{array}$ & $\begin{array}{l}<.004 \\
<.004 \\
<.004 \\
<.004 \\
<.004\end{array}$ & $\begin{array}{l}<.1138 \\
<.1138 \\
<.1138 \\
<.1138 \\
<.1138\end{array}$ & $\begin{array}{l}<.004 \\
<.004 \\
<.004 \\
<.004 \\
<.004\end{array}$ & $\begin{array}{l}<.003 \\
<.003 \\
<.003 \\
<.003 \\
<.003\end{array}$ & $\begin{array}{l}<.07 \\
<.07 \\
<.07 \\
<.07 \\
<.07\end{array}$ \\
\hline $\begin{array}{l}375447099245001 \\
375828101111801 \\
380331100352801 \\
382947100443201 \\
383008101315601\end{array}$ & $\begin{array}{l}<.0102 \\
<.0102 \\
<.0102 \\
<.0102 \\
<.0102\end{array}$ & $\begin{array}{l}<.08 \\
<.08 \\
<.08 \\
<.08 \\
<.08\end{array}$ & $\begin{array}{l}<.001 \\
<.001 \\
<.001 \\
<.001 \\
<.001\end{array}$ & $\begin{array}{l}<.006 \\
<.006 \\
<.006 \\
<.006 \\
<.006\end{array}$ & $\begin{array}{l}.29 \\
<.05 \\
<.05 \\
<.05 \\
<.05\end{array}$ & $\begin{array}{l}<.05 \\
<.05 \\
<.05 \\
<.05 \\
<.05\end{array}$ & $\begin{array}{l}<.002 \\
<.002 \\
<.002 \\
<.002 \\
<.002\end{array}$ & $\begin{array}{l}<.004 \\
<.004 \\
<.004 \\
<.004 \\
<.004\end{array}$ & $\begin{array}{l}<.1138 \\
<.1138 \\
<.1138 \\
<.1138 \\
<.1138\end{array}$ & $\begin{array}{l}<.004 \\
<.004 \\
<.004 \\
<.004 \\
<.004\end{array}$ & $\begin{array}{l}<.003 \\
<.003 \\
<.003 \\
<.003 \\
<.003\end{array}$ & $\begin{array}{l}<.07 \\
<.07 \\
<.07 \\
<.07 \\
<.07\end{array}$ \\
\hline $\begin{array}{l}383758101195801 \\
383919101040101 \\
385210100164501 \\
385904099522201 \\
390622101003201\end{array}$ & $\begin{array}{l}<.0102 \\
<.0102 \\
<.0102 \\
<.0102 \\
<.0102\end{array}$ & $\begin{array}{l}<.08 \\
<.08 \\
<.08 \\
<.08 \\
<.08\end{array}$ & $\begin{array}{l}<.001 \\
<.001 \\
<.001 \\
<.001 \\
<.001\end{array}$ & $\begin{array}{l}<.006 \\
<.006 \\
<.006 \\
<.006 \\
<.006\end{array}$ & $\begin{array}{l}<.05 \\
<.05 \\
<.05 \\
.14 \\
.19\end{array}$ & $\begin{array}{l}<.05 \\
<.05 \\
<.05 \\
<.05 \\
\quad .15\end{array}$ & $\begin{array}{l}<.002 \\
<.002 \\
<.002 \\
.005 \\
.006\end{array}$ & $\begin{array}{l}<.004 \\
<.004 \\
<.004 \\
<.004 \\
<.004\end{array}$ & $\begin{array}{l}<.1138 \\
<.1138 \\
<.1138 \\
<.1138 \\
<.1138\end{array}$ & $\begin{array}{l}<.004 \\
<.004 \\
<.004 \\
<.004 \\
<.004\end{array}$ & $\begin{array}{l}<.003 \\
<.003 \\
<.003 \\
<.003 \\
<.003\end{array}$ & $\begin{array}{l}<.07 \\
<.07 \\
<.07 \\
<.07 \\
<.07\end{array}$ \\
\hline
\end{tabular}




\begin{tabular}{|c|c|c|c|c|c|c|c|c|c|c|c|c|}
\hline STATION NUMBER & $\begin{array}{l}\text { NICOSUL } \\
\text { FURON } \\
\text { WATER } \\
\text { FLTRD } \\
\text { REC } \\
\text { (UG/L) }\end{array}$ & $\begin{array}{c}\text { NORFLUR } \\
\text { AZON, } \\
\text { WATER, } \\
\text { FLTRD, } \\
\text { GF } 0.7 \mathrm{U} \\
\text { REC } \\
\text { (UG/L) }\end{array}$ & $\begin{array}{c}\text { ORY- } \\
\text { ZALIN, } \\
\text { WATER, } \\
\text { FLTRD, } \\
\text { GF 0.7U } \\
\text { REC } \\
\text { (UG/L) }\end{array}$ & $\begin{array}{l}\text { OXAMYL } \\
\text { OXIME } \\
\text { WATER } \\
\text { FLTRD } \\
\text { REC } \\
\text { (UG/L) }\end{array}$ & $\begin{array}{c}\text { OXAMYL, } \\
\text { WATER, } \\
\text { FLTRD, } \\
\text { GF 0.7U } \\
\text { REC } \\
\text { (UG/L) }\end{array}$ & $\begin{array}{l}\text { P, } P^{\prime} \\
\text { DDE } \\
\text { DISSOLV } \\
(U G / L)\end{array}$ & $\begin{array}{l}\text { PARA- } \\
\text { THION, } \\
\text { DIS- } \\
\text { SOLVED } \\
\text { (UG/L) }\end{array}$ & $\begin{array}{l}\text { PEB- } \\
\text { ULATE } \\
\text { WATER } \\
\text { FILTRD } \\
0.7 \text { U } \\
\text { GF, REC } \\
\text { (UG/L) }\end{array}$ & $\begin{array}{l}\text { PENDI- } \\
\text { METH- } \\
\text { ALIN } \\
\text { WAT FLT } \\
0.7 \text { U } \\
\text { GE, REC } \\
\text { (UG/L) }\end{array}$ & $\begin{array}{c}\text { PER- } \\
\text { METHRIN } \\
\text { CIS } \\
\text { WAT FLT } \\
0.7 \text { U } \\
\text { GF, REC } \\
\text { (UG/L) }\end{array}$ & $\begin{array}{l}\text { PHORATE } \\
\text { WATER } \\
\text { FLTRD } \\
0.7 \text { U } \\
\text { GF, REC } \\
\text { (UG/L) }\end{array}$ & $\begin{array}{c}\text { PIC- } \\
\text { LORAM, } \\
\text { WATER, } \\
\text { FLTRD, } \\
\text { GF } 0.7 \mathrm{U} \\
\text { REC } \\
\text { (UG/L) }\end{array}$ \\
\hline $\begin{array}{l}344800101324901 \\
345826100580501 \\
351656101161101 \\
351914101204401 \\
352035100293301\end{array}$ & $\begin{array}{l}<.065 \\
<.065 \\
<.065 \\
<.065 \\
<.065\end{array}$ & $\begin{array}{l}<.08 \\
<.08 \\
<.08 \\
<.08 \\
<.08\end{array}$ & $\begin{array}{l}<.07 \\
<.07 \\
<.07 \\
<.07 \\
<.07\end{array}$ & $\begin{array}{l}<.064 \\
<.064 \\
<.064 \\
<.064 \\
<.064\end{array}$ & $\begin{array}{l}<.02 \\
<.02 \\
<.02 \\
<.02 \\
<.02\end{array}$ & $\begin{array}{l}<.006 \\
<.006 \\
<.006 \\
<.006 \\
<.006\end{array}$ & $\begin{array}{l}<.004 \\
<.004 \\
<.004 \\
<.004 \\
<.004\end{array}$ & $\begin{array}{l}<.004 \\
<.004 \\
<.004 \\
<.004 \\
<.004\end{array}$ & $\begin{array}{l}<.004 \\
<.004 \\
<.004 \\
<.004 \\
<.004\end{array}$ & $\begin{array}{l}<.005 \\
<.005 \\
<.005 \\
<.005 \\
<.005\end{array}$ & $\begin{array}{l}<.002 \\
<.002 \\
<.002 \\
<.002 \\
<.002\end{array}$ & $\begin{array}{l}<.07 \\
<.07 \\
<.07 \\
<.07 \\
<.07\end{array}$ \\
\hline $\begin{array}{l}352249100425401 \\
352513101372101 \\
352909101084001 \\
353110100550401 \\
353941102350201\end{array}$ & $\begin{array}{l}<.065 \\
<.065 \\
<.065 \\
<.065 \\
<.065\end{array}$ & $\begin{array}{l}<.08 \\
<.08 \\
<.08 \\
<.08 \\
<.08\end{array}$ & $\begin{array}{l}<.07 \\
<.07 \\
<.07 \\
<.07 \\
<.07\end{array}$ & $\begin{array}{l}<.064 \\
<.064 \\
<.064 \\
<.064 \\
<.064\end{array}$ & $\begin{array}{l}<.02 \\
<.02 \\
<.02 \\
<.02 \\
<.02\end{array}$ & $\begin{array}{l}<.006 \\
<.006 \\
<.006 \\
<.006 \\
<.006\end{array}$ & $\begin{array}{l}<.004 \\
<.004 \\
<.004 \\
<.004 \\
<.004\end{array}$ & $\begin{array}{l}<.004 \\
<.004 \\
<.004 \\
<.004 \\
<.004\end{array}$ & $\begin{array}{l}<.004 \\
<.004 \\
<.004 \\
<.004 \\
<.004\end{array}$ & $\begin{array}{l}<.005 \\
<.005 \\
<.005 \\
<.005 \\
<.005\end{array}$ & $\begin{array}{l}<.002 \\
<.002 \\
<.002 \\
<.002 \\
<.002\end{array}$ & $\begin{array}{l}<.07 \\
<.07 \\
<.07 \\
<.07 \\
<.07\end{array}$ \\
\hline $\begin{array}{l}354248100501501 \\
354331102183601 \\
354348102543601 \\
354656099480301 \\
354728102295901\end{array}$ & $\begin{array}{l}<.065 \\
<.065 \\
<.065 \\
<.065 \\
<.065\end{array}$ & $\begin{array}{l}<.08 \\
<.08 \\
<.08 \\
<.08 \\
<.08\end{array}$ & $\begin{array}{l}<.07 \\
<.07 \\
<.07 \\
<.07 \\
<.07\end{array}$ & $\begin{array}{l}<.064 \\
<.064 \\
<.064 \\
<.064 \\
<.064\end{array}$ & $\begin{array}{l}<.02 \\
<.02 \\
<.02 \\
<.02 \\
<.02\end{array}$ & $\begin{array}{l}<.006 \\
<.006 \\
<.006 \\
<.006 \\
<.006\end{array}$ & $\begin{array}{l}<.004 \\
<.004 \\
<.004 \\
<.004 \\
<.004\end{array}$ & $\begin{array}{l}<.004 \\
<.004 \\
<.004 \\
<.004 \\
<.004\end{array}$ & $\begin{array}{l}<.004 \\
<.004 \\
<.004 \\
<.004 \\
<.004\end{array}$ & $\begin{array}{l}<.005 \\
<.005 \\
<.005 \\
<.005 \\
<.005\end{array}$ & $\begin{array}{l}<.002 \\
<.002 \\
<.002 \\
<.002 \\
<.002\end{array}$ & $\begin{array}{l}<.07 \\
<.07 \\
<.07 \\
<.07 \\
<.07\end{array}$ \\
\hline $\begin{array}{l}354918102020901 \\
355701100313001 \\
355852101274101 \\
355916103215201 \\
360703102361901\end{array}$ & $\begin{array}{l}<.065 \\
<.065 \\
<.065 \\
<.065 \\
<.065\end{array}$ & $\begin{array}{l}<.08 \\
<.08 \\
<.08 \\
<.08 \\
<.08\end{array}$ & $\begin{array}{l}<.07 \\
<.07 \\
<.07 \\
<.07 \\
<.07\end{array}$ & $\begin{array}{l}<.064 \\
<.064 \\
<.064 \\
<.064 \\
<.064\end{array}$ & $\begin{array}{l}<.02 \\
<.02 \\
<.02 \\
<.02 \\
<.02\end{array}$ & $\begin{array}{l}<.006 \\
<.006 \\
<.006 \\
<.006 \\
<.006\end{array}$ & $\begin{array}{l}<.004 \\
<.004 \\
<.004 \\
<.004 \\
<.004\end{array}$ & $\begin{array}{l}<.004 \\
<.004 \\
<.004 \\
<.004 \\
<.004\end{array}$ & $\begin{array}{l}<.010 \\
<.004 \\
<.004 \\
<.004 \\
<.004\end{array}$ & $\begin{array}{l}<.005 \\
<.005 \\
<.005 \\
<.005 \\
<.005\end{array}$ & $\begin{array}{l}<.002 \\
<.002 \\
<.002 \\
<.002 \\
<.002\end{array}$ & $\begin{array}{l}<.07 \\
<.07 \\
<.07 \\
<.07 \\
<.07\end{array}$ \\
\hline $\begin{array}{l}360838102560301 \\
360944100162101 \\
361014100221001 \\
361049100564901 \\
361054101393601\end{array}$ & $\begin{array}{l}<.065 \\
<.065 \\
<.065 \\
<.065 \\
<.065\end{array}$ & $\begin{array}{l}<.08 \\
<.08 \\
<.08 \\
-- \\
<.08\end{array}$ & $\begin{array}{l}<.07 \\
<.07 \\
<.07 \\
<.07 \\
<.07\end{array}$ & $\begin{array}{l}<.064 \\
<.064 \\
<.064 \\
-- \\
<.064\end{array}$ & $\begin{array}{l}<.02 \\
<.02 \\
<.02 \\
<.02 \\
<.02\end{array}$ & $\begin{array}{l}<.006 \\
<.006 \\
<.006 \\
<.006 \\
<.006\end{array}$ & $\begin{array}{l}<.004 \\
<.004 \\
<.004 \\
<.004 \\
<.004\end{array}$ & $\begin{array}{l}<.004 \\
<.004 \\
<.004 \\
<.004 \\
<.004\end{array}$ & $\begin{array}{l}<.004 \\
<.004 \\
<.004 \\
<.004 \\
<.004\end{array}$ & $\begin{array}{l}<.005 \\
<.005 \\
<.005 \\
<.005 \\
<.005\end{array}$ & $\begin{array}{l}<.002 \\
<.002 \\
<.002 \\
<.002 \\
<.002\end{array}$ & $\begin{array}{l}<.07 \\
<.07 \\
<.07 \\
<.07 \\
<.07\end{array}$ \\
\hline $\begin{array}{l}361114099420501 \\
361517102065301 \\
362115101173901 \\
362134102035101 \\
362615100435801\end{array}$ & $\begin{array}{l}<.065 \\
<.065 \\
<.065 \\
<.065 \\
<.065\end{array}$ & $\begin{array}{l}<.08 \\
<.08 \\
<.08 \\
<.08 \\
<.08\end{array}$ & $\begin{array}{l}<.07 \\
<.07 \\
<.07 \\
<.07 \\
<.07\end{array}$ & $\begin{array}{l}<.064 \\
<.064 \\
<.064 \\
<.064 \\
<.064\end{array}$ & $\begin{array}{l}<.02 \\
<.02 \\
<.02 \\
<.02 \\
<.02\end{array}$ & $\begin{array}{l}<.006 \\
<.006 \\
<.006 \\
<.006 \\
<.006\end{array}$ & $\begin{array}{l}<.004 \\
<.004 \\
<.004 \\
<.004 \\
<.004\end{array}$ & $\begin{array}{l}<.004 \\
<.004 \\
<.004 \\
<.004 \\
<.004\end{array}$ & $\begin{array}{l}<.004 \\
<.004 \\
<.004 \\
<.004 \\
<.004\end{array}$ & $\begin{array}{l}<.005 \\
<.005 \\
<.005 \\
<.005 \\
<.005\end{array}$ & $\begin{array}{l}<.002 \\
<.002 \\
<.002 \\
<.002 \\
<.002\end{array}$ & $\begin{array}{l}<.07 \\
<.07 \\
<.07 \\
<.07 \\
<.07\end{array}$ \\
\hline $\begin{array}{l}362744102334901 \\
363057101384701 \\
363104100035501 \\
363154099310401 \\
363157102565601\end{array}$ & $\begin{array}{l}<.065 \\
<.065 \\
<.065 \\
<.065 \\
<.065\end{array}$ & $\begin{array}{l}<.08 \\
<.08 \\
<.08 \\
<.08 \\
<.08\end{array}$ & $\begin{array}{l}<.07 \\
<.07 \\
<.07 \\
<.07 \\
<.07\end{array}$ & $\begin{array}{l}<.064 \\
<.064 \\
<.064 \\
<.064 \\
<.064\end{array}$ & $\begin{array}{l}<.02 \\
<.02 \\
<.02 \\
<.02 \\
<.02\end{array}$ & $\begin{array}{l}<.006 \\
<.006 \\
<.006 \\
<.006 \\
<.006\end{array}$ & $\begin{array}{l}<.004 \\
<.004 \\
<.004 \\
<.004 \\
<.004\end{array}$ & $\begin{array}{l}<.004 \\
<.004 \\
<.004 \\
<.004 \\
<.004\end{array}$ & $\begin{array}{l}<.004 \\
<.004 \\
<.004 \\
<.004 \\
<.004\end{array}$ & $\begin{array}{l}<.005 \\
<.005 \\
<.005 \\
<.005 \\
<.005\end{array}$ & $\begin{array}{l}<.002 \\
<.002 \\
<.002 \\
<.002 \\
<.002\end{array}$ & $\begin{array}{l}<.07 \\
<.07 \\
<.07 \\
<.07 \\
<.07\end{array}$ \\
\hline $\begin{array}{l}363239100301801 \\
363427102440401 \\
364219101394101 \\
364411102321201 \\
365223102113001\end{array}$ & $\begin{array}{l}<.065 \\
<.065 \\
<.065 \\
<.065 \\
<.065\end{array}$ & $\begin{array}{l}<.08 \\
<.08 \\
<.08 \\
<.08 \\
<.08\end{array}$ & $\begin{array}{l}<.07 \\
<.07 \\
<.07 \\
<.07 \\
<.07\end{array}$ & $\begin{array}{l}<.064 \\
<.064 \\
<.064 \\
<.064 \\
<.064\end{array}$ & $\begin{array}{l}<.02 \\
<.02 \\
<.02 \\
<.02 \\
<.02\end{array}$ & $\begin{array}{l}<.006 \\
<.006 \\
<.006 \\
<.006 \\
<.006\end{array}$ & $\begin{array}{l}<.004 \\
<.004 \\
<.004 \\
<.004 \\
<.004\end{array}$ & $\begin{array}{l}<.004 \\
<.004 \\
<.004 \\
<.004 \\
<.004\end{array}$ & $\begin{array}{l}<.004 \\
<.004 \\
<.004 \\
.098 \\
<.004\end{array}$ & $\begin{array}{l}<.005 \\
<.005 \\
<.005 \\
<.005 \\
<.005\end{array}$ & $\begin{array}{l}<.002 \\
<.002 \\
<.002 \\
<.002 \\
<.002\end{array}$ & $\begin{array}{l}<.07 \\
<.07 \\
<.07 \\
<.07 \\
<.07\end{array}$ \\
\hline $\begin{array}{l}365422101083701 \\
365445100381901 \\
365821101375301 \\
365934101573001 \\
370358100510301\end{array}$ & $\begin{array}{l}<.065 \\
<.065 \\
<.065 \\
<.065 \\
<.065\end{array}$ & $\begin{array}{l}<.08 \\
<.08 \\
<.08 \\
<.08 \\
<.08\end{array}$ & $\begin{array}{l}<.07 \\
<.07 \\
<.07 \\
<.07 \\
<.07\end{array}$ & $\begin{array}{l}<.064 \\
<.064 \\
<.064 \\
<.064 \\
<.064\end{array}$ & $\begin{array}{l}<.02 \\
<.02 \\
<.02 \\
<.02 \\
<.02\end{array}$ & $\begin{array}{l}<.006 \\
<.006 \\
<.006 \\
<.006 \\
<.006\end{array}$ & $\begin{array}{l}<.004 \\
<.004 \\
<.004 \\
<.004 \\
<.004\end{array}$ & $\begin{array}{l}<.004 \\
<.004 \\
<.004 \\
<.004 \\
<.004\end{array}$ & $\begin{array}{l}<.004 \\
<.004 \\
<.004 \\
<.004 \\
<.004\end{array}$ & $\begin{array}{l}<.005 \\
<.005 \\
<.005 \\
<.005 \\
<.005\end{array}$ & $\begin{array}{l}<.002 \\
<.002 \\
<.002 \\
<.002 \\
<.002\end{array}$ & $\begin{array}{l}<.07 \\
<.07 \\
<.07 \\
<.07 \\
<.07\end{array}$ \\
\hline $\begin{array}{l}370458101514401 \\
370724100281601 \\
371738101220301 \\
372534100443501 \\
372649101344701\end{array}$ & $\begin{array}{l}<.065 \\
<.065 \\
<.065 \\
<.065 \\
<.065\end{array}$ & $\begin{array}{l}<.08 \\
<.08 \\
<.08 \\
<.08 \\
<.08\end{array}$ & $\begin{array}{l}<.07 \\
<.07 \\
<.07 \\
<.07 \\
<.07\end{array}$ & $\begin{array}{l}<.064 \\
<.064 \\
<.064 \\
<.064 \\
<.064\end{array}$ & $\begin{array}{l}<.02 \\
<.02 \\
<.02 \\
<.02 \\
<.02\end{array}$ & $\begin{array}{l}<.006 \\
<.006 \\
<.006 \\
<.006 \\
<.006\end{array}$ & $\begin{array}{l}<.004 \\
<.004 \\
<.004 \\
<.004 \\
<.004\end{array}$ & $\begin{array}{l}<.004 \\
<.004 \\
<.004 \\
<.004 \\
<.004\end{array}$ & $\begin{array}{l}<.004 \\
<.004 \\
<.004 \\
<.004 \\
<.004\end{array}$ & $\begin{array}{l}<.005 \\
<.005 \\
<.005 \\
<.005 \\
<.005\end{array}$ & $\begin{array}{l}<.002 \\
<.002 \\
<.002 \\
<.002 \\
<.002\end{array}$ & $\begin{array}{l}<.07 \\
<.07 \\
<.07 \\
<.07 \\
<.07\end{array}$ \\
\hline $\begin{array}{l}372956099512201 \\
373229101193201 \\
373345101070801 \\
373507102162001 \\
373527100312701\end{array}$ & $\begin{array}{l}<.065 \\
<.065 \\
<.065 \\
<.065 \\
<.065\end{array}$ & $\begin{array}{l}<.08 \\
<.08 \\
<.08 \\
<.08 \\
<.08\end{array}$ & $\begin{array}{l}<.07 \\
<.07 \\
<.07 \\
<.07 \\
<.07\end{array}$ & $\begin{array}{l}<.064 \\
<.064 \\
<.064 \\
<.064 \\
<.064\end{array}$ & $\begin{array}{l}<.02 \\
<.02 \\
<.02 \\
<.02 \\
<.02\end{array}$ & $\begin{array}{l}<.006 \\
<.006 \\
<.006 \\
<.006 \\
<.006\end{array}$ & $\begin{array}{l}<.004 \\
<.004 \\
<.004 \\
<.004 \\
<.004\end{array}$ & $\begin{array}{l}<.004 \\
<.004 \\
<.004 \\
<.004 \\
<.004\end{array}$ & $\begin{array}{l}<.004 \\
<.004 \\
<.004 \\
<.004 \\
<.004\end{array}$ & $\begin{array}{l}<.005 \\
<.005 \\
<.005 \\
<.005 \\
<.005\end{array}$ & $\begin{array}{l}<.002 \\
<.002 \\
<.002 \\
<.002 \\
<.002\end{array}$ & $\begin{array}{l}<.07 \\
<.07 \\
<.07 \\
<.07 \\
<.07\end{array}$ \\
\hline $\begin{array}{l}373559102314901 \\
373732099291201 \\
374535102110301 \\
374650100181901 \\
375129100532301\end{array}$ & $\begin{array}{l}<.065 \\
<.065 \\
<.065 \\
<.065 \\
<.065\end{array}$ & $\begin{array}{l}<.08 \\
<.08 \\
<.08 \\
<.08 \\
<.08\end{array}$ & $\begin{array}{l}<.07 \\
<.07 \\
<.07 \\
<.07 \\
<.07\end{array}$ & $\begin{array}{l}<.064 \\
<.064 \\
<.064 \\
<.064 \\
<.064\end{array}$ & $\begin{array}{l}<.02 \\
<.02 \\
<.02 \\
<.02 \\
<.02\end{array}$ & $\begin{array}{l}<.006 \\
<.006 \\
<.006 \\
<.006 \\
<.006\end{array}$ & $\begin{array}{l}<.004 \\
<.004 \\
<.004 \\
<.004 \\
<.004\end{array}$ & $\begin{array}{l}<.004 \\
<.004 \\
<.004 \\
<.004 \\
<.004\end{array}$ & $\begin{array}{l}<.004 \\
<.004 \\
<.004 \\
<.004 \\
<.004\end{array}$ & $\begin{array}{l}<.005 \\
<.005 \\
<.005 \\
<.005 \\
<.005\end{array}$ & $\begin{array}{l}<.002 \\
<.002 \\
<.002 \\
<.002 \\
<.002\end{array}$ & $\begin{array}{l}<.07 \\
<.07 \\
<.07 \\
<.07 \\
<.07\end{array}$ \\
\hline $\begin{array}{l}375447099245001 \\
375828101111801 \\
380331100352801 \\
382947100443201 \\
383008101315601\end{array}$ & $\begin{array}{l}<.065 \\
<.065 \\
<.065 \\
<.065 \\
<.065\end{array}$ & $\begin{array}{l}<.08 \\
<.08 \\
<.08 \\
<.08 \\
<.08\end{array}$ & $\begin{array}{l}<.07 \\
<.07 \\
<.07 \\
<.07 \\
<.07\end{array}$ & $\begin{array}{l}<.064 \\
<.064 \\
<.064 \\
<.064 \\
<.064\end{array}$ & $\begin{array}{l}<.02 \\
<.02 \\
<.02 \\
<.02 \\
<.02\end{array}$ & $\begin{array}{l}<.006 \\
<.006 \\
<.006 \\
<.006 \\
<.006\end{array}$ & $\begin{array}{l}<.004 \\
<.004 \\
<.004 \\
<.004 \\
<.004\end{array}$ & $\begin{array}{l}<.004 \\
<.004 \\
<.004 \\
<.004 \\
<.004\end{array}$ & $\begin{array}{l}<.004 \\
<.004 \\
<.004 \\
<.004 \\
<.004\end{array}$ & $\begin{array}{l}<.005 \\
<.005 \\
<.005 \\
<.005 \\
<.005\end{array}$ & $\begin{array}{l}<.002 \\
<.002 \\
<.002 \\
<.002 \\
<.002\end{array}$ & $\begin{array}{l}<.07 \\
<.07 \\
<.07 \\
<.07 \\
<.07\end{array}$ \\
\hline $\begin{array}{l}383758101195801 \\
383919101040101 \\
385210100164501 \\
385904099522201 \\
390622101003201\end{array}$ & $\begin{array}{l}<.065 \\
<.065 \\
<.065 \\
<.065 \\
<.065\end{array}$ & $\begin{array}{l}<.08 \\
<.08 \\
<.08 \\
<.08 \\
<.08\end{array}$ & $\begin{array}{l}<.07 \\
<.07 \\
<.07 \\
<.07 \\
<.07\end{array}$ & $\begin{array}{l}<.064 \\
<.064 \\
<.064 \\
<.064 \\
<.064\end{array}$ & $\begin{array}{l}<.02 \\
<.02 \\
<.02 \\
<.02 \\
<.02\end{array}$ & $\begin{array}{l}<.006 \\
<.006 \\
<.006 \\
<.006 \\
<.006\end{array}$ & $\begin{array}{l}<.004 \\
<.004 \\
<.004 \\
<.004 \\
<.004\end{array}$ & $\begin{array}{l}<.004 \\
<.004 \\
<.004 \\
<.004 \\
<.004\end{array}$ & $\begin{array}{l}<.004 \\
<.004 \\
<.004 \\
<.004 \\
<.004\end{array}$ & $\begin{array}{l}<.005 \\
<.005 \\
<.005 \\
<.005 \\
<.005\end{array}$ & $\begin{array}{l}<.002 \\
<.002 \\
<.002 \\
<.002 \\
<.002\end{array}$ & $\begin{array}{l}<.07 \\
<.07 \\
<.07 \\
\text { E. } 32 \\
\text { E. } 61\end{array}$ \\
\hline $\begin{array}{l}390830102052001 \\
390838100411701 \\
391044100051001 \\
391921101385501\end{array}$ & $\begin{array}{l}<.065 \\
<.065 \\
<.065 \\
<.065\end{array}$ & $\begin{array}{l}<.08 \\
<.08 \\
<.08 \\
<.08\end{array}$ & $\begin{array}{l}<.07 \\
<.07 \\
<.07 \\
<.07\end{array}$ & $\begin{array}{l}<.064 \\
<.064 \\
<.064 \\
<.064\end{array}$ & $\begin{array}{l}<.02 \\
<.02 \\
<.02 \\
<.02\end{array}$ & $\begin{array}{l}<.006 \\
<.006 \\
<.006 \\
<.006\end{array}$ & $\begin{array}{l}<.004 \\
<.004 \\
<.004 \\
<.004\end{array}$ & $\begin{array}{l}<.004 \\
<.004 \\
<.004 \\
<.004\end{array}$ & $\begin{array}{l}<.004 \\
<.004 \\
<.004 \\
<.004\end{array}$ & $\begin{array}{l}<.005 \\
<.005 \\
<.005 \\
<.005\end{array}$ & $\begin{array}{l}<.002 \\
<.002 \\
<.002 \\
<.002\end{array}$ & $\begin{array}{l}<.07 \\
<.07 \\
<.07 \\
<.07\end{array}$ \\
\hline
\end{tabular}


Appendix 1. Water-quality data from 74 domestic water-supply wells completed in the central High Plains aquifer-Continued

\begin{tabular}{|c|c|c|c|c|c|c|c|c|c|c|c|c|}
\hline STATION NUMBER & $\begin{array}{l}\text { PRO- } \\
\text { METON, } \\
\text { WATER, } \\
\text { DISS, } \\
\text { REC } \\
\text { (UG/L) }\end{array}$ & $\begin{array}{l}\text { PRON- } \\
\text { AMIDE } \\
\text { WATER } \\
\text { FLTRD } \\
0.7 \text { U } \\
\text { GE, REC } \\
\text { (UG/L) }\end{array}$ & $\begin{array}{l}\text { PROPA- } \\
\text { CHLOR, } \\
\text { WATER, } \\
\text { DISS, } \\
\text { REC } \\
\text { (UG/L) }\end{array}$ & $\begin{array}{l}\text { PRO- } \\
\text { PANIL } \\
\text { WATER } \\
\text { FLTRD } \\
0.7 \text { U } \\
\text { GF, REC } \\
\text { (UG/L) }\end{array}$ & $\begin{array}{c}\text { PRO- } \\
\text { PARGITE } \\
\text { WATER } \\
\text { FLTRD } \\
0.7 \text { U } \\
\text { GE, REC } \\
\text { (UG/L) }\end{array}$ & $\begin{array}{c}\text { PRO- } \\
\text { PHAM, } \\
\text { WATER, } \\
\text { FLTRD, } \\
\text { GF } 0.7 \mathrm{U} \\
\text { REC } \\
(\mathrm{UG} / \mathrm{L})\end{array}$ & $\begin{array}{l}\text { PROP- } \\
\text { ICONA- } \\
\text { ZOLE , } \\
\text { WATER } \\
\text { FLTRD } \\
\text { REC } \\
\text { (UG/L) }\end{array}$ & $\begin{array}{c}\text { PRO- } \\
\text { POXUR, } \\
\text { WATER, } \\
\text { FLTRD, } \\
\text { GF } 0.7 \mathrm{U} \\
\text { REC } \\
\text { (UG/L) }\end{array}$ & $\begin{array}{l}\text { SIDURON } \\
\text { WATER } \\
\text { FLTRD } \\
\text { REC } \\
\text { (UG/L) }\end{array}$ & $\begin{array}{l}\text { SI- } \\
\text { MAZINE, } \\
\text { WATER, } \\
\text { DISS, } \\
\text { REC } \\
\text { (UG/L) }\end{array}$ & $\begin{array}{c}\text { SULFO- } \\
\text { MET- } \\
\text { RURON } \\
\text { METHYL } \\
\text { WTR FLT } \\
\text { REC } \\
\text { (UG/L) }\end{array}$ & $\begin{array}{c}\text { TEBU- } \\
\text { THIURON } \\
\text { WATER } \\
\text { FLTRD } \\
0.7 \text { U } \\
\text { GF, REC } \\
(U G / L)\end{array}$ \\
\hline $\begin{array}{l}344800101324901 \\
345826100580501 \\
351656101161101 \\
351914101204401 \\
352035100293301\end{array}$ & $\begin{array}{l}<.018 \\
<.018 \\
<.018 \\
<.018 \\
<.018\end{array}$ & $\begin{array}{l}<.003 \\
<.003 \\
<.003 \\
<.003 \\
<.003\end{array}$ & $\begin{array}{l}<.007 \\
<.007 \\
<.007 \\
<.007 \\
<.007\end{array}$ & $\begin{array}{l}<.004 \\
<.004 \\
<.004 \\
<.004 \\
<.004\end{array}$ & $\begin{array}{l}<.013 \\
<.013 \\
<.013 \\
<.013 \\
\quad--\end{array}$ & $\begin{array}{l}<.07 \\
<.07 \\
<.07 \\
<.07 \\
<.07\end{array}$ & $\begin{array}{l}<.064 \\
<.064 \\
<.064 \\
<.064 \\
<.064\end{array}$ & $\begin{array}{l}<.06 \\
<.06 \\
<.06 \\
<.06 \\
<.06\end{array}$ & $\begin{array}{l}<.093 \\
<.093 \\
<.093 \\
<.093 \\
<.093\end{array}$ & $\begin{array}{l}<.005 \\
<.005 \\
<.005 \\
<.005 \\
<.005\end{array}$ & $\begin{array}{l}<.039 \\
<.039 \\
<.039 \\
<.039 \\
<.039\end{array}$ & $\begin{array}{l}.103 \\
<.010 \\
<.010 \\
<.010 \\
<.010\end{array}$ \\
\hline $\begin{array}{l}352249100425401 \\
352513101372101 \\
352909101084001 \\
353110100550401 \\
353941102350201\end{array}$ & $\begin{array}{l}<.018 \\
<.018 \\
<.018 \\
<.018 \\
<.018\end{array}$ & $\begin{array}{l}<.003 \\
<.003 \\
<.003 \\
<.003 \\
<.003\end{array}$ & $\begin{array}{l}<.007 \\
<.007 \\
<.007 \\
<.007 \\
<.007\end{array}$ & $\begin{array}{l}<.004 \\
<.004 \\
<.004 \\
<.004 \\
<.004\end{array}$ & $\begin{array}{l}<.013 \\
<.013 \\
<.013 \\
<.013 \\
<.013\end{array}$ & $\begin{array}{l}<.07 \\
<.07 \\
<.07 \\
<.07 \\
<.07\end{array}$ & $\begin{array}{l}<.064 \\
<.064 \\
<.064 \\
<.064 \\
<.064\end{array}$ & $\begin{array}{l}<.06 \\
<.06 \\
<.06 \\
<.06 \\
<.06\end{array}$ & $\begin{array}{l}<.093 \\
<.093 \\
<.093 \\
<.093 \\
<.093\end{array}$ & $\begin{array}{l}<.005 \\
<.005 \\
<.005 \\
<.005 \\
<.005\end{array}$ & $\begin{array}{l}<.039 \\
<.039 \\
<.039 \\
<.039 \\
<.039\end{array}$ & $\begin{array}{l}<.010 \\
<.010 \\
<.010 \\
<.010 \\
<.010\end{array}$ \\
\hline $\begin{array}{l}354248100501501 \\
354331102183601 \\
354348102543601 \\
354656099480301 \\
354728102295901\end{array}$ & $\begin{array}{l}<.018 \\
<.018 \\
<.018 \\
<.018 \\
<.018\end{array}$ & $\begin{array}{l}<.003 \\
<.003 \\
<.003 \\
<.003 \\
<.003\end{array}$ & $\begin{array}{l}<.007 \\
<.007 \\
<.007 \\
<.007 \\
<.007\end{array}$ & $\begin{array}{l}<.004 \\
<.004 \\
<.004 \\
<.004 \\
<.004\end{array}$ & $\begin{array}{l}<.013 \\
<.013 \\
<.013 \\
<.013 \\
<.013\end{array}$ & $\begin{array}{l}<.07 \\
<.07 \\
<.07 \\
<.07 \\
<.07\end{array}$ & $\begin{array}{l}<.064 \\
<.064 \\
<.064 \\
<.064 \\
<.064\end{array}$ & $\begin{array}{l}<.06 \\
<.06 \\
<.06 \\
<.06 \\
<.06\end{array}$ & $\begin{array}{l}<.093 \\
-- \\
<.093 \\
<.093 \\
<.093\end{array}$ & $\begin{array}{l}<.005 \\
<.005 \\
<.005 \\
<.005 \\
<.005\end{array}$ & $\begin{array}{l}<.039 \\
<.039 \\
<.039 \\
<.039 \\
<.039\end{array}$ & $\begin{array}{l}<.010 \\
<.010 \\
<.010 \\
<.010 \\
<.010\end{array}$ \\
\hline $\begin{array}{l}354918102020901 \\
355701100313001 \\
355852101274101 \\
355916103215201 \\
360703102361901\end{array}$ & $\begin{array}{l}.056 \\
<.018 \\
<.018 \\
<.018 \\
<.018\end{array}$ & $\begin{array}{l}<.003 \\
<.003 \\
<.003 \\
<.003 \\
<.003\end{array}$ & $\begin{array}{l}<.007 \\
<.007 \\
<.007 \\
<.007 \\
<.007\end{array}$ & $\begin{array}{l}<.004 \\
<.004 \\
<.004 \\
<.004 \\
<.004\end{array}$ & $\begin{array}{c}<.013 \\
<.013 \\
-- \\
<.013 \\
<.013\end{array}$ & $\begin{array}{l}<.07 \\
<.07 \\
<.07 \\
<.07 \\
<.07\end{array}$ & $\begin{array}{l}<.064 \\
<.064 \\
<.064 \\
<.064 \\
<.064\end{array}$ & $\begin{array}{l}<.06 \\
<.06 \\
<.06 \\
<.06 \\
<.06\end{array}$ & $\begin{array}{l}<.093 \\
<.093 \\
<.093 \\
<.093 \\
<.093\end{array}$ & $\begin{array}{l}.014 \\
<.005 \\
<.005 \\
<.005 \\
<.005\end{array}$ & $\begin{array}{l}<.039 \\
<.039 \\
<.039 \\
<.039 \\
<.039\end{array}$ & $\begin{array}{l}<.010 \\
<.010 \\
<.010 \\
<.010 \\
<.010\end{array}$ \\
\hline $\begin{array}{l}360838102560301 \\
360944100162101 \\
361014100221001 \\
361049100564901 \\
361054101393601\end{array}$ & $\begin{array}{l}<.018 \\
<.018 \\
<.018 \\
<.018 \\
<.018\end{array}$ & $\begin{array}{l}<.003 \\
<.003 \\
<.003 \\
<.003 \\
<.003\end{array}$ & $\begin{array}{l}<.007 \\
<.007 \\
<.007 \\
<.007 \\
<.007\end{array}$ & $\begin{array}{l}<.004 \\
<.004 \\
<.004 \\
<.004 \\
<.004\end{array}$ & $\begin{array}{l}<.013 \\
<.013 \\
<.013 \\
<.013 \\
<.013\end{array}$ & $\begin{array}{l}<.07 \\
<.07 \\
<.07 \\
<.07 \\
<.07\end{array}$ & $\begin{array}{l}<.064 \\
<.064 \\
<.064 \\
<.064 \\
<.064\end{array}$ & $\begin{array}{l}<.06 \\
<.06 \\
<.06 \\
<.06 \\
<.06\end{array}$ & $\begin{array}{l}<.093 \\
<.093 \\
<.093 \\
<.093 \\
<.093\end{array}$ & $\begin{array}{l}<.005 \\
<.005 \\
<.005 \\
<.005 \\
<.005\end{array}$ & $\begin{array}{l}<.039 \\
<.039 \\
<.039 \\
<.039 \\
<.039\end{array}$ & $\begin{array}{l}<.010 \\
<.010 \\
<.010 \\
<.010 \\
<.010\end{array}$ \\
\hline $\begin{array}{l}361114099420501 \\
361517102065301 \\
362115101173901 \\
362134102035101 \\
362615100435801\end{array}$ & $\begin{array}{l}<.018 \\
<.018 \\
<.018 \\
<.018 \\
<.018\end{array}$ & $\begin{array}{l}<.003 \\
<.003 \\
<.003 \\
<.003 \\
<.003\end{array}$ & $\begin{array}{l}<.007 \\
<.007 \\
<.007 \\
<.007 \\
<.007\end{array}$ & $\begin{array}{l}<.004 \\
<.004 \\
<.004 \\
<.004 \\
<.004\end{array}$ & $\begin{array}{l}<.013 \\
<.013 \\
<.013 \\
<.013 \\
<.013\end{array}$ & $\begin{array}{l}<.07 \\
<.07 \\
<.07 \\
<.07 \\
<.07\end{array}$ & $\begin{array}{l}<.064 \\
<.064 \\
<.064 \\
<.064 \\
<.064\end{array}$ & $\begin{array}{l}<.06 \\
<.06 \\
<.06 \\
<.06 \\
<.06\end{array}$ & $\begin{array}{l}<.093 \\
<.093 \\
<.093 \\
<.093 \\
<.093\end{array}$ & $\begin{array}{l}<.005 \\
<.005 \\
<.005 \\
<.005 \\
<.005\end{array}$ & $\begin{array}{l}<.039 \\
<.039 \\
<.039 \\
<.039 \\
<.039\end{array}$ & $\begin{array}{l}<.010 \\
<.010 \\
<.010 \\
<.010 \\
<.010\end{array}$ \\
\hline $\begin{array}{l}362744102334901 \\
363057101384701 \\
363104100035501 \\
363154099310401 \\
363157102565601\end{array}$ & $\begin{array}{l}<.018 \\
<.018 \\
<.018 \\
<.018 \\
<.018\end{array}$ & $\begin{array}{l}<.003 \\
<.003 \\
<.003 \\
<.003 \\
<.003\end{array}$ & $\begin{array}{l}<.007 \\
<.007 \\
<.007 \\
<.007 \\
<.007\end{array}$ & $\begin{array}{l}<.004 \\
<.004 \\
<.004 \\
<.004 \\
<.004\end{array}$ & $\begin{aligned} & -- \\
< & .013 \\
< & <.013 \\
< & <.013 \\
< & <.013\end{aligned}$ & $\begin{array}{l}<.07 \\
<.07 \\
<.07 \\
<.07 \\
<.07\end{array}$ & $\begin{array}{l}<.064 \\
<.064 \\
<.064 \\
<.064 \\
<.064\end{array}$ & $\begin{array}{l}<.06 \\
<.06 \\
<.06 \\
<.06 \\
<.06\end{array}$ & $\begin{array}{l}<.093 \\
<.093 \\
<.093 \\
<.093 \\
<.093\end{array}$ & $\begin{array}{l}<.005 \\
<.005 \\
<.005 \\
<.005 \\
<.005\end{array}$ & $\begin{array}{l}<.039 \\
<.039 \\
<.039 \\
<.039 \\
<.039\end{array}$ & $\begin{array}{l}<.010 \\
<.010 \\
<.010 \\
<.010 \\
<.010\end{array}$ \\
\hline $\begin{array}{l}363239100301801 \\
363427102440401 \\
364219101394101 \\
364411102321201 \\
365223102113001\end{array}$ & $\begin{array}{l}<.018 \\
<.018 \\
<.018 \\
<.018 \\
<.018\end{array}$ & $\begin{array}{l}<.003 \\
<.003 \\
<.003 \\
<.003 \\
<.003\end{array}$ & $\begin{array}{l}<.007 \\
<.007 \\
<.007 \\
<.007 \\
<.007\end{array}$ & $\begin{array}{l}<.004 \\
<.004 \\
<.004 \\
<.004 \\
<.004\end{array}$ & $\begin{array}{l}<.013 \\
<.013 \\
<.013 \\
<.013 \\
<.013\end{array}$ & $\begin{array}{l}<.07 \\
<.07 \\
<.07 \\
<.07 \\
<.07\end{array}$ & $\begin{array}{l}<.064 \\
<.064 \\
<.064 \\
<.064 \\
<.064\end{array}$ & $\begin{array}{l}<.06 \\
<.06 \\
<.06 \\
<.06 \\
<.06\end{array}$ & $\begin{array}{l}<.093 \\
<.093 \\
<.093 \\
<.093 \\
<.093\end{array}$ & $\begin{array}{l}<.005 \\
<.005 \\
<.005 \\
<.005 \\
<.005\end{array}$ & $\begin{array}{l}<.039 \\
<.039 \\
<.039 \\
<.039 \\
<.039\end{array}$ & $\begin{array}{l}<.010 \\
<.010 \\
<.010 \\
<.010 \\
<.010\end{array}$ \\
\hline $\begin{array}{l}365422101083701 \\
365445100381901 \\
365821101375301 \\
365934101573001 \\
370358100510301\end{array}$ & $\begin{array}{l}<.018 \\
<.018 \\
<.018 \\
<.018 \\
<.018\end{array}$ & $\begin{array}{l}<.003 \\
<.003 \\
<.003 \\
<.003 \\
<.003\end{array}$ & $\begin{array}{l}<.007 \\
<.007 \\
<.007 \\
<.007 \\
<.007\end{array}$ & $\begin{array}{l}<.004 \\
<.004 \\
<.004 \\
<.004 \\
<.004\end{array}$ & $\begin{array}{l}<.013 \\
<.013 \\
<.013 \\
<.013 \\
<.013\end{array}$ & $\begin{array}{l}<.07 \\
<.07 \\
<.07 \\
<.07 \\
<.07\end{array}$ & $\begin{array}{l}<.064 \\
<.064 \\
<.064 \\
<.064 \\
<.064\end{array}$ & $\begin{array}{l}<.06 \\
<.06 \\
<.06 \\
<.06 \\
<.06\end{array}$ & $\begin{array}{l}<.093 \\
<.093 \\
<.093 \\
<.093 \\
<.093\end{array}$ & $\begin{array}{l}<.005 \\
<.005 \\
<.005 \\
<.005 \\
<.005\end{array}$ & $\begin{array}{l}<.039 \\
<.039 \\
<.039 \\
<.039 \\
<.039\end{array}$ & $\begin{array}{l}<.010 \\
<.010 \\
<.010 \\
<.010 \\
<.010\end{array}$ \\
\hline $\begin{array}{l}370458101514401 \\
370724100281601 \\
371738101220301 \\
372534100443501 \\
372649101344701\end{array}$ & $\begin{array}{l}<.018 \\
<.018 \\
<.018 \\
<.018 \\
<.018\end{array}$ & $\begin{array}{l}<.003 \\
<.003 \\
<.003 \\
<.003 \\
<.003\end{array}$ & $\begin{array}{l}<.007 \\
<.007 \\
<.007 \\
<.007 \\
<.007\end{array}$ & $\begin{array}{l}<.004 \\
<.004 \\
<.004 \\
<.004 \\
<.004\end{array}$ & $\begin{array}{l}<.013 \\
<.013 \\
<.013 \\
<.013 \\
<.013\end{array}$ & $\begin{array}{l}<.07 \\
<.07 \\
<.07 \\
<.07 \\
<.07\end{array}$ & $\begin{array}{l}<.064 \\
<.064 \\
<.064 \\
<.064 \\
<.064\end{array}$ & $\begin{array}{l}<.06 \\
<.06 \\
<.06 \\
<.06 \\
<.06\end{array}$ & $\begin{array}{l}<.093 \\
<.093 \\
<.093 \\
<.093 \\
<.093\end{array}$ & $\begin{array}{l}<.005 \\
<.005 \\
<.005 \\
<.005 \\
<.005\end{array}$ & $\begin{array}{l}<.039 \\
<.039 \\
<.039 \\
<.039 \\
<.039\end{array}$ & $\begin{array}{l}<.077 \\
<.010 \\
<.010 \\
<.010 \\
<.010\end{array}$ \\
\hline $\begin{array}{l}372956099512201 \\
373229101193201 \\
373345101070801 \\
373507102162001 \\
373527100312701\end{array}$ & $\begin{array}{l}<.018 \\
<.018 \\
<.018 \\
<.018 \\
<.018\end{array}$ & $\begin{array}{l}<.003 \\
<.003 \\
<.003 \\
<.003 \\
<.003\end{array}$ & $\begin{array}{l}<.007 \\
<.007 \\
<.007 \\
<.007 \\
<.007\end{array}$ & $\begin{array}{l}<.004 \\
<.004 \\
<.004 \\
<.004 \\
<.004\end{array}$ & $\begin{array}{l}<.013 \\
<.013 \\
<.013 \\
<.013 \\
<.013\end{array}$ & $\begin{array}{l}<.07 \\
<.07 \\
<.07 \\
<.07 \\
<.07\end{array}$ & $\begin{array}{l}<.064 \\
<.064 \\
<.064 \\
<.064 \\
<.064\end{array}$ & $\begin{array}{l}<.06 \\
<.06 \\
<.06 \\
<.06 \\
<.06\end{array}$ & $\begin{array}{l}<.093 \\
<.093 \\
<.093 \\
<.093 \\
<.093\end{array}$ & $\begin{array}{l}<.005 \\
<.005 \\
<.005 \\
<.005 \\
<.005\end{array}$ & $\begin{array}{l}<.039 \\
<.039 \\
<.039 \\
<.039 \\
<.039\end{array}$ & $\begin{array}{l}<.010 \\
<.010 \\
<.010 \\
<.010 \\
<.010\end{array}$ \\
\hline $\begin{array}{l}373559102314901 \\
373732099291201 \\
374535102110301 \\
374650100181901 \\
375129100532301\end{array}$ & $\begin{array}{l}<.018 \\
<.018 \\
<.018 \\
<.018 \\
<.018\end{array}$ & $\begin{array}{l}<.003 \\
<.003 \\
<.003 \\
<.003 \\
<.003\end{array}$ & $\begin{array}{l}<.007 \\
<.007 \\
<.007 \\
<.007 \\
<.007\end{array}$ & $\begin{array}{l}<.004 \\
<.004 \\
<.004 \\
<.004 \\
<.004\end{array}$ & $\begin{array}{l}<.013 \\
<.013 \\
<.013 \\
<.013 \\
<.013\end{array}$ & $\begin{array}{l}<.07 \\
<.07 \\
<.07 \\
<.07 \\
<.07\end{array}$ & $\begin{array}{l}<.064 \\
<.064 \\
<.064 \\
<.064 \\
<.064\end{array}$ & $\begin{array}{l}<.06 \\
<.06 \\
<.06 \\
<.06 \\
<.06\end{array}$ & $\begin{array}{l}<.093 \\
<.093 \\
<.093 \\
<.093 \\
<.093\end{array}$ & $\begin{array}{l}<.005 \\
<.005 \\
<.005 \\
<.005 \\
<.005\end{array}$ & $\begin{array}{l}<.039 \\
<.039 \\
<.039 \\
<.039 \\
<.039\end{array}$ & $\begin{array}{l}<.010 \\
<.010 \\
<.010 \\
<.010 \\
<.010\end{array}$ \\
\hline $\begin{array}{l}375447099245001 \\
375828101111801 \\
380331100352801 \\
382947100443201 \\
383008101315601\end{array}$ & $\begin{array}{l}<.018 \\
<.018 \\
<.018 \\
<.018 \\
<.018\end{array}$ & $\begin{array}{l}<.003 \\
<.003 \\
<.003 \\
<.003 \\
<.003\end{array}$ & $\begin{array}{l}<.007 \\
<.007 \\
<.007 \\
<.007 \\
<.007\end{array}$ & $\begin{array}{l}<.004 \\
<.004 \\
<.004 \\
<.004 \\
<.004\end{array}$ & $\begin{array}{l}<.013 \\
<.013 \\
<.013 \\
<.013 \\
<.013\end{array}$ & $\begin{array}{l}<.07 \\
<.07 \\
<.07 \\
<.07 \\
<.07\end{array}$ & $\begin{array}{l}<.064 \\
<.064 \\
<.064 \\
<.064 \\
<.064\end{array}$ & $\begin{array}{l}<.06 \\
<.06 \\
<.06 \\
<.06 \\
<.06\end{array}$ & $\begin{array}{l}<.093 \\
<.093 \\
<.093 \\
<.093 \\
<.093\end{array}$ & $\begin{array}{l}<.005 \\
<.005 \\
<.005 \\
<.005 \\
<.005\end{array}$ & $\begin{array}{l}<.039 \\
<.039 \\
<.039 \\
<.039 \\
<.039\end{array}$ & $\begin{array}{l}<.010 \\
<.010 \\
<.010 \\
<.010 \\
<.010\end{array}$ \\
\hline $\begin{array}{l}383758101195801 \\
383919101040101 \\
385210100164501 \\
385904099522201 \\
390622101003201\end{array}$ & $\begin{array}{l}<.018 \\
<.018 \\
<.018 \\
<.018 \\
<.018\end{array}$ & $\begin{array}{l}<.003 \\
<.003 \\
<.003 \\
<.003 \\
<.003\end{array}$ & $\begin{array}{l}<.007 \\
<.007 \\
<.007 \\
<.007 \\
<.007\end{array}$ & $\begin{array}{l}<.004 \\
<.004 \\
<.004 \\
<.004 \\
<.004\end{array}$ & $\begin{array}{l}<.013 \\
<.013 \\
<.013 \\
<.013 \\
<.013\end{array}$ & $\begin{array}{l}<.07 \\
<.07 \\
<.07 \\
<.07 \\
<.07\end{array}$ & $\begin{array}{l}<.064 \\
<.064 \\
<.064 \\
<.064 \\
<.064\end{array}$ & $\begin{array}{l}<.06 \\
<.06 \\
<.06 \\
<.06 \\
<.06\end{array}$ & $\begin{array}{l}<.093 \\
<.093 \\
<.093 \\
<.093 \\
<.093\end{array}$ & $\begin{array}{l}<.005 \\
<.005 \\
<.005 \\
.011 \\
<.005\end{array}$ & $\begin{array}{l}<.039 \\
<.039 \\
<.039 \\
<.039 \\
<.039\end{array}$ & $\begin{array}{l}<.010 \\
<.010 \\
<.010 \\
<.010 \\
<.010\end{array}$ \\
\hline
\end{tabular}




\begin{tabular}{|c|c|c|c|c|c|c|c|c|c|c|c|c|}
\hline STATION NUMBER & $\begin{array}{l}\text { TER- } \\
\text { BACIL, } \\
\text { WATER, } \\
\text { DISS, } \\
\text { REC } \\
\text { (UG/L) }\end{array}$ & $\begin{array}{l}\text { TER- } \\
\text { BACIL } \\
\text { WATER } \\
\text { FLTRD } \\
0.7 \text { U } \\
\text { GF, REC } \\
\text { (UG/L) }\end{array}$ & $\begin{array}{l}\text { TER- } \\
\text { BUFOS } \\
\text { WATER } \\
\text { FLTRD } \\
0.7 \text { U } \\
\text { GF, REC } \\
\text { (UG/L) }\end{array}$ & $\begin{array}{c}\text { THIO- } \\
\text { BENCARB } \\
\text { WATER } \\
\text { FLTRD } \\
0.7 \text { U } \\
\text { GF, REC } \\
\text { (UG/L) }\end{array}$ & $\begin{array}{l}\text { TRIAL- } \\
\text { LATE } \\
\text { WATER } \\
\text { FLTRD } \\
0.7 \text { U } \\
\text { GF, REC } \\
\text { (UG/L) }\end{array}$ & $\begin{array}{c}\text { TRI- } \\
\text { BENURON } \\
\text { METHYL } \\
\text { WATER } \\
\text { FLTRD } \\
\text { (UG/L) }\end{array}$ & $\begin{array}{c}\text { TRI- } \\
\text { CLOPYR, } \\
\text { WATER, } \\
\text { FLTRD, } \\
\text { GF } 0.7 \mathrm{U} \\
\text { REC } \\
\text { (UG/L) }\end{array}$ & $\begin{array}{l}\text { TRI- } \\
\text { FLUR- } \\
\text { ALIN } \\
\text { WAT FLT } \\
0.7 \text { U } \\
\text { GF, REC } \\
\text { (UG/L) }\end{array}$ & $\begin{array}{l}1,1,1- \\
\text { TRI- } \\
\text { CHLORO- } \\
\text { ETHANE } \\
\text { TOTAL } \\
\text { (UG/L) }\end{array}$ & $\begin{array}{c}1,1,2- \\
\text { TRI- } \\
\text { CHLORO- } \\
\text { ETHANE } \\
\text { TOTAL } \\
\text { (UG/L) }\end{array}$ & $\begin{array}{c}1,1-D I- \\
\text { CHLORO- } \\
\text { ETHANE } \\
\text { TOTAL } \\
\text { (UG/L) }\end{array}$ & $\begin{array}{c}1,1-D I- \\
\text { CHLORO- } \\
\text { ETHYL- } \\
\text { ENE } \\
\text { TOTAL } \\
\text { (UG/L) }\end{array}$ \\
\hline $\begin{array}{l}344800101324901 \\
345826100580501 \\
351656101161101 \\
351914101204401 \\
352035100293301\end{array}$ & $\begin{array}{l}<.10 \\
<.10 \\
<.10 \\
<.10 \\
<.10\end{array}$ & $\begin{array}{l}<.007 \\
<.007 \\
<.007 \\
<.007 \\
<.007\end{array}$ & $\begin{array}{l}<.013 \\
<.013 \\
<.013 \\
<.013 \\
<.013\end{array}$ & $\begin{array}{l}<.002 \\
<.002 \\
<.002 \\
<.002 \\
<.002\end{array}$ & $\begin{array}{l}<.001 \\
<.001 \\
<.001 \\
<.001 \\
<.001\end{array}$ & $\begin{array}{l}<.07 \\
<.07 \\
<.07 \\
<.07 \\
<.07\end{array}$ & $\begin{array}{l}<.10 \\
<.10 \\
<.10 \\
<.10 \\
<.10\end{array}$ & $\begin{array}{l}<.002 \\
<.002 \\
<.002 \\
<.002 \\
<.002\end{array}$ & $\begin{array}{l}<.03 \\
<.03 \\
<.03 \\
<.03 \\
<.03\end{array}$ & $\begin{array}{l}<.06 \\
<.06 \\
<.06 \\
<.06 \\
<.06\end{array}$ & $\begin{array}{l}<.07 \\
<.07 \\
<.07 \\
<.07 \\
<.07\end{array}$ & $\begin{array}{l}<.04 \\
<.04 \\
<.04 \\
<.04 \\
<.04\end{array}$ \\
\hline $\begin{array}{l}352249100425401 \\
352513101372101 \\
352909101084001 \\
353110100550401 \\
353941102350201\end{array}$ & $\begin{array}{l}<.10 \\
<.10 \\
<.10 \\
<.10 \\
<.10\end{array}$ & $\begin{array}{l}<.007 \\
<.007 \\
<.007 \\
<.007 \\
<.007\end{array}$ & $\begin{array}{l}<.013 \\
<.013 \\
<.013 \\
<.013 \\
<.013\end{array}$ & $\begin{array}{l}<.002 \\
<.002 \\
<.002 \\
<.002 \\
<.002\end{array}$ & $\begin{array}{l}<.001 \\
<.001 \\
<.001 \\
<.001 \\
<.001\end{array}$ & $\begin{array}{l}<.07 \\
<.07 \\
<.07 \\
<.07 \\
<.07\end{array}$ & $\begin{array}{l}<.10 \\
<.10 \\
<.10 \\
<.10 \\
<.10\end{array}$ & $\begin{array}{l}<.002 \\
<.002 \\
<.002 \\
<.002 \\
<.002\end{array}$ & $\begin{array}{l}<.03 \\
<.03 \\
<.03 \\
<.03 \\
<.03\end{array}$ & $\begin{array}{l}<.06 \\
<.06 \\
<.06 \\
<.06 \\
<.06\end{array}$ & $\begin{array}{l}<.07 \\
<.07 \\
<.07 \\
<.07 \\
<.07\end{array}$ & $\begin{array}{l}<.04 \\
<.04 \\
<.04 \\
<.04 \\
<.04\end{array}$ \\
\hline $\begin{array}{l}354248100501501 \\
354331102183601 \\
354348102543601 \\
354656099480301 \\
354728102295901\end{array}$ & $\begin{array}{l}<.10 \\
<.10 \\
<.10 \\
<.10 \\
<.10\end{array}$ & $\begin{array}{l}<.007 \\
<.007 \\
<.007 \\
<.007 \\
<.007\end{array}$ & $\begin{array}{l}<.013 \\
<.013 \\
<.013 \\
<.013 \\
<.013\end{array}$ & $\begin{array}{l}<.002 \\
<.002 \\
<.002 \\
<.002 \\
<.002\end{array}$ & $\begin{array}{l}<.001 \\
<.001 \\
<.001 \\
<.001 \\
<.001\end{array}$ & $\begin{array}{l}<.07 \\
<.07 \\
<.07 \\
<.07 \\
<.07\end{array}$ & $\begin{array}{l}<.10 \\
<.10 \\
<.10 \\
<.10 \\
<.10\end{array}$ & $\begin{array}{l}<.002 \\
<.002 \\
<.002 \\
<.002 \\
<.002\end{array}$ & $\begin{array}{l}<.03 \\
<.03 \\
<.03 \\
<.03 \\
<.03\end{array}$ & $\begin{array}{l}<.06 \\
<.06 \\
<.06 \\
<.06 \\
<.06\end{array}$ & $\begin{array}{l}<.07 \\
<.07 \\
<.07 \\
<.07 \\
<.07\end{array}$ & $\begin{array}{l}<.04 \\
<.04 \\
<.04 \\
<.04 \\
<.04\end{array}$ \\
\hline $\begin{array}{l}354918102020901 \\
355701100313001 \\
355852101274101 \\
355916103215201 \\
360703102361901\end{array}$ & $\begin{array}{l}<.10 \\
<.10 \\
<.10 \\
<.10 \\
<.10\end{array}$ & $\begin{array}{l}<.007 \\
<.007 \\
<.007 \\
<.007 \\
<.007\end{array}$ & $\begin{array}{l}<.013 \\
<.013 \\
<.013 \\
<.013 \\
<.013\end{array}$ & $\begin{array}{l}<.002 \\
<.002 \\
<.002 \\
<.002 \\
<.002\end{array}$ & $\begin{array}{l}<.001 \\
<.001 \\
<.001 \\
<.001 \\
<.001\end{array}$ & $\begin{array}{l}<.07 \\
<.07 \\
<.07 \\
<.07 \\
<.07\end{array}$ & $\begin{array}{l}<.10 \\
<.10 \\
<.10 \\
<.10 \\
<.10\end{array}$ & $\begin{array}{l}<.002 \\
<.002 \\
<.002 \\
<.002 \\
<.002\end{array}$ & $\begin{array}{l}<.03 \\
<.03 \\
<.03 \\
<.03 \\
<.03\end{array}$ & $\begin{array}{l}<.06 \\
<.06 \\
<.06 \\
<.06 \\
<.06\end{array}$ & $\begin{array}{l}<.07 \\
<.07 \\
<.07 \\
<.07 \\
<.07\end{array}$ & $\begin{array}{l}<.04 \\
<.04 \\
<.04 \\
<.04 \\
<.04\end{array}$ \\
\hline $\begin{array}{l}360838102560301 \\
360944100162101 \\
361014100221001 \\
361049100564901 \\
361054101393601\end{array}$ & $\begin{array}{l}<.10 \\
<.10 \\
<.10 \\
<.10 \\
<.10\end{array}$ & $\begin{array}{l}<.007 \\
<.007 \\
<.007 \\
<.007 \\
<.007\end{array}$ & $\begin{array}{l}<.013 \\
<.013 \\
<.013 \\
<.013 \\
<.013\end{array}$ & $\begin{array}{l}<.002 \\
<.002 \\
<.002 \\
<.002 \\
<.002\end{array}$ & $\begin{array}{l}<.001 \\
<.001 \\
<.001 \\
<.001 \\
<.001\end{array}$ & $\begin{array}{l}<.07 \\
<.07 \\
<.07 \\
<.07 \\
<.07\end{array}$ & $\begin{array}{l}<.10 \\
<.10 \\
<.10 \\
<.10 \\
<.10\end{array}$ & $\begin{array}{l}<.002 \\
<.002 \\
<.002 \\
<.002 \\
<.002\end{array}$ & $\begin{array}{l}<.03 \\
<.03 \\
<.03 \\
<.03 \\
<.03\end{array}$ & $\begin{array}{l}<.06 \\
<.06 \\
<.06 \\
<.06 \\
<.06\end{array}$ & $\begin{array}{l}<.07 \\
<.07 \\
<.07 \\
<.07 \\
<.07\end{array}$ & $\begin{array}{l}<.04 \\
<.04 \\
<.04 \\
<.04 \\
<.04\end{array}$ \\
\hline $\begin{array}{l}361114099420501 \\
361517102065301 \\
362115101173901 \\
362134102035101 \\
362615100435801\end{array}$ & $\begin{array}{l}<.10 \\
<.10 \\
<.10 \\
<.10 \\
<.10\end{array}$ & $\begin{array}{l}<.007 \\
<.007 \\
<.007 \\
<.007 \\
<.007\end{array}$ & $\begin{array}{l}<.013 \\
<.013 \\
<.013 \\
<.013 \\
<.013\end{array}$ & $\begin{array}{l}<.002 \\
<.002 \\
<.002 \\
<.002 \\
<.002\end{array}$ & $\begin{array}{l}<.001 \\
<.001 \\
<.001 \\
<.001 \\
<.001\end{array}$ & $\begin{array}{l}<.07 \\
<.07 \\
<.07 \\
<.07 \\
<.07\end{array}$ & $\begin{array}{l}<.10 \\
<.10 \\
<.10 \\
<.10 \\
<.10\end{array}$ & $\begin{array}{l}<.002 \\
<.002 \\
<.002 \\
<.002 \\
<.002\end{array}$ & $\begin{array}{l}<.03 \\
<.03 \\
<.03 \\
<.03 \\
<.03\end{array}$ & $\begin{array}{l}<.06 \\
<.06 \\
<.06 \\
<.06 \\
<.06\end{array}$ & $\begin{array}{l}<.07 \\
<.07 \\
<.07 \\
<.07 \\
<.07\end{array}$ & $\begin{array}{l}<.04 \\
<.04 \\
<.04 \\
<.04 \\
<.04\end{array}$ \\
\hline $\begin{array}{l}362744102334901 \\
363057101384701 \\
363104100035501 \\
363154099310401 \\
363157102565601\end{array}$ & $\begin{array}{l}<.10 \\
<.10 \\
<.10 \\
<.10 \\
<.10\end{array}$ & $\begin{array}{l}<.007 \\
<.007 \\
<.007 \\
<.007 \\
<.007\end{array}$ & $\begin{array}{l}<.013 \\
<.013 \\
<.013 \\
<.013 \\
<.013\end{array}$ & $\begin{array}{l}<.002 \\
<.002 \\
<.002 \\
<.002 \\
<.002\end{array}$ & $\begin{array}{l}<.001 \\
<.001 \\
<.001 \\
<.001 \\
<.001\end{array}$ & $\begin{array}{l}<.07 \\
<.07 \\
<.07 \\
<.07 \\
<.07\end{array}$ & $\begin{array}{l}<.10 \\
<.10 \\
<.10 \\
<.10 \\
<.10\end{array}$ & $\begin{array}{l}<.002 \\
<.002 \\
<.002 \\
<.002 \\
<.002\end{array}$ & $\begin{array}{l}<.03 \\
<.03 \\
<.03 \\
<.03 \\
<.03\end{array}$ & $\begin{array}{l}<.06 \\
<.06 \\
<.06 \\
<.06 \\
<.06\end{array}$ & $\begin{array}{l}<.07 \\
<.07 \\
<.07 \\
<.07 \\
<.07\end{array}$ & $\begin{array}{l}<.04 \\
<.04 \\
<.04 \\
<.04 \\
<.04\end{array}$ \\
\hline $\begin{array}{l}363239100301801 \\
363427102440401 \\
364219101394101 \\
364411102321201 \\
365223102113001\end{array}$ & $\begin{array}{l}<.10 \\
<.10 \\
<.10 \\
<.10 \\
<.10\end{array}$ & $\begin{array}{l}<.007 \\
<.007 \\
<.007 \\
<.007 \\
<.007\end{array}$ & $\begin{array}{l}<.013 \\
<.013 \\
<.013 \\
<.013 \\
<.013\end{array}$ & $\begin{array}{l}<.002 \\
<.002 \\
<.002 \\
<.002 \\
<.002\end{array}$ & $\begin{array}{l}<.001 \\
<.001 \\
<.001 \\
<.001 \\
<.001\end{array}$ & $\begin{array}{l}<.07 \\
<.07 \\
<.07 \\
<.07 \\
<.07\end{array}$ & $\begin{array}{l}<.10 \\
<.10 \\
<.10 \\
<.10 \\
<.10\end{array}$ & $\begin{array}{l}<.002 \\
<.002 \\
<.002 \\
<.002 \\
<.002\end{array}$ & $\begin{array}{l}<.03 \\
<.03 \\
<.03 \\
<.03 \\
<.03\end{array}$ & $\begin{array}{l}<.06 \\
<.06 \\
<.06 \\
<.06 \\
<.06\end{array}$ & $\begin{array}{l}<.07 \\
<.07 \\
<.07 \\
<.07 \\
<.07\end{array}$ & $\begin{array}{l}<.04 \\
<.04 \\
<.04 \\
<.04 \\
<.04\end{array}$ \\
\hline $\begin{array}{l}365422101083701 \\
365445100381901 \\
365821101375301 \\
365934101573001 \\
370358100510301\end{array}$ & $\begin{array}{l}<.10 \\
<.10 \\
<.10 \\
<.10 \\
<.10\end{array}$ & $\begin{array}{l}<.007 \\
<.007 \\
<.007 \\
<.007 \\
<.007\end{array}$ & $\begin{array}{l}<.013 \\
<.013 \\
<.013 \\
<.013 \\
<.013\end{array}$ & $\begin{array}{l}<.002 \\
<.002 \\
<.002 \\
<.002 \\
<.002\end{array}$ & $\begin{array}{l}<.001 \\
<.001 \\
<.001 \\
<.001 \\
<.001\end{array}$ & $\begin{array}{l}<.07 \\
<.07 \\
<.07 \\
<.07 \\
<.07\end{array}$ & $\begin{array}{l}<.10 \\
<.10 \\
<.10 \\
<.10 \\
<.10\end{array}$ & $\begin{array}{l}<.002 \\
<.002 \\
<.002 \\
<.002 \\
<.002\end{array}$ & $\begin{array}{l}<.03 \\
<.03 \\
<.03 \\
<.03 \\
<.03\end{array}$ & $\begin{array}{l}<.06 \\
<.06 \\
<.06 \\
<.06 \\
<.06\end{array}$ & $\begin{array}{l}<.07 \\
<.07 \\
<.07 \\
<.07 \\
<.07\end{array}$ & $\begin{array}{l}<.04 \\
<.04 \\
<.04 \\
<.04 \\
<.04\end{array}$ \\
\hline $\begin{array}{l}370458101514401 \\
370724100281601 \\
371738101220301 \\
372534100443501 \\
372649101344701\end{array}$ & $\begin{array}{l}<.10 \\
<.10 \\
<.10 \\
<.10 \\
<.10\end{array}$ & $\begin{array}{l}<.007 \\
<.007 \\
<.007 \\
<.007 \\
<.007\end{array}$ & $\begin{array}{l}<.013 \\
<.013 \\
<.013 \\
<.013 \\
<.013\end{array}$ & $\begin{array}{l}<.002 \\
<.002 \\
<.002 \\
<.002 \\
<.002\end{array}$ & $\begin{array}{l}<.001 \\
<.001 \\
<.001 \\
<.001 \\
<.001\end{array}$ & $\begin{array}{l}<.07 \\
<.07 \\
<.07 \\
<.07 \\
<.07\end{array}$ & $\begin{array}{l}<.10 \\
<.10 \\
<.10 \\
<.10 \\
<.10\end{array}$ & $\begin{array}{l}<.002 \\
<.002 \\
<.002 \\
<.002 \\
<.002\end{array}$ & $\begin{array}{l}<.03 \\
<.03 \\
<.03 \\
<.03 \\
<.03\end{array}$ & $\begin{array}{l}<.06 \\
<.06 \\
<.06 \\
<.06 \\
<.06\end{array}$ & $\begin{array}{l}<.07 \\
<.07 \\
<.07 \\
<.07 \\
<.07\end{array}$ & $\begin{array}{l}<.04 \\
<.04 \\
<.04 \\
<.04 \\
<.04\end{array}$ \\
\hline $\begin{array}{l}372956099512201 \\
373229101193201 \\
373345101070801 \\
373507102162001 \\
373527100312701\end{array}$ & $\begin{array}{l}<.10 \\
<.10 \\
<.10 \\
<.10 \\
<.10\end{array}$ & $\begin{array}{l}<.007 \\
<.007 \\
<.007 \\
<.007 \\
<.007\end{array}$ & $\begin{array}{l}<.013 \\
<.013 \\
<.013 \\
<.013 \\
<.013\end{array}$ & $\begin{array}{l}<.002 \\
<.002 \\
<.002 \\
<.002 \\
<.002\end{array}$ & $\begin{array}{l}<.001 \\
<.001 \\
<.001 \\
<.001 \\
<.001\end{array}$ & $\begin{array}{l}<.07 \\
<.07 \\
<.07 \\
<.07 \\
<.07\end{array}$ & $\begin{array}{l}<.10 \\
<.10 \\
<.10 \\
<.10 \\
<.10\end{array}$ & $\begin{array}{l}<.002 \\
<.002 \\
<.002 \\
<.002 \\
<.002\end{array}$ & $\begin{array}{l}<.03 \\
<.03 \\
<.03 \\
<.03 \\
<.03\end{array}$ & $\begin{array}{l}<.06 \\
<.06 \\
<.06 \\
<.06 \\
<.06\end{array}$ & $\begin{array}{l}<.07 \\
<.07 \\
<.07 \\
<.07 \\
<.07\end{array}$ & $\begin{array}{l}<.04 \\
<.04 \\
<.04 \\
<.04 \\
<.04\end{array}$ \\
\hline $\begin{array}{l}373559102314901 \\
373732099291201 \\
374535102110301 \\
374650100181901 \\
375129100532301\end{array}$ & $\begin{array}{l}<.10 \\
<.10 \\
<.10 \\
<.10 \\
<.10\end{array}$ & $\begin{array}{l}<.007 \\
<.007 \\
<.007 \\
<.007 \\
<.007\end{array}$ & $\begin{array}{l}<.013 \\
<.013 \\
<.013 \\
<.013 \\
<.013\end{array}$ & $\begin{array}{l}<.002 \\
<.002 \\
<.002 \\
<.002 \\
<.002\end{array}$ & $\begin{array}{l}<.001 \\
<.001 \\
<.001 \\
<.001 \\
<.001\end{array}$ & $\begin{array}{l}<.07 \\
<.07 \\
<.07 \\
<.07 \\
<.07\end{array}$ & $\begin{array}{l}<.10 \\
<.10 \\
<.10 \\
<.10 \\
<.10\end{array}$ & $\begin{array}{l}<.002 \\
<.002 \\
<.002 \\
<.002 \\
<.002\end{array}$ & $\begin{array}{l}<.03 \\
<.03 \\
<.03 \\
<.03 \\
<.03\end{array}$ & $\begin{array}{l}<.06 \\
<.06 \\
<.06 \\
<.06 \\
<.06\end{array}$ & $\begin{array}{l}<.07 \\
<.07 \\
<.07 \\
<.07 \\
<.07\end{array}$ & $\begin{array}{l}<.04 \\
<.04 \\
<.04 \\
<.04 \\
<.04\end{array}$ \\
\hline $\begin{array}{l}375447099245001 \\
375828101111801 \\
380331100352801 \\
382947100443201 \\
383008101315601\end{array}$ & $\begin{array}{l}<.10 \\
<.10 \\
<.10 \\
<.10 \\
<.10\end{array}$ & $\begin{array}{l}<.007 \\
<.007 \\
<.007 \\
<.007 \\
<.007\end{array}$ & $\begin{array}{l}<.013 \\
<.013 \\
<.013 \\
<.013 \\
<.013\end{array}$ & $\begin{array}{l}<.002 \\
<.002 \\
<.002 \\
<.002 \\
<.002\end{array}$ & $\begin{array}{l}<.001 \\
<.001 \\
<.001 \\
<.001 \\
<.001\end{array}$ & $\begin{array}{l}<.07 \\
<.07 \\
<.07 \\
<.07 \\
<.07\end{array}$ & $\begin{array}{l}<.10 \\
<.10 \\
<.10 \\
<.10 \\
<.10\end{array}$ & $\begin{array}{l}<.002 \\
<.002 \\
<.002 \\
<.002 \\
<.002\end{array}$ & $\begin{array}{l}<.03 \\
<.03 \\
<.03 \\
<.03 \\
<.03\end{array}$ & $\begin{array}{l}<.06 \\
<.06 \\
<.06 \\
<.06 \\
<.06\end{array}$ & $\begin{array}{l}<.07 \\
<.07 \\
<.07 \\
<.07 \\
<.07\end{array}$ & $\begin{array}{l}<.04 \\
<.04 \\
<.04 \\
<.04 \\
<.04\end{array}$ \\
\hline $\begin{array}{l}383758101195801 \\
383919101040101 \\
385210100164501 \\
385904099522201 \\
390622101003201\end{array}$ & $\begin{array}{l}<.10 \\
<.10 \\
<.10 \\
<.10 \\
<.10\end{array}$ & $\begin{array}{l}<.007 \\
<.007 \\
<.007 \\
<.007 \\
<.007\end{array}$ & $\begin{array}{l}<.013 \\
<.013 \\
<.013 \\
<.013 \\
<.013\end{array}$ & $\begin{array}{l}<.002 \\
<.002 \\
<.002 \\
<.002 \\
<.002\end{array}$ & $\begin{array}{l}<.001 \\
<.001 \\
<.001 \\
<.001 \\
<.001\end{array}$ & $\begin{array}{l}<.07 \\
<.07 \\
<.07 \\
<.07 \\
<.07\end{array}$ & $\begin{array}{l}<.10 \\
<.10 \\
<.10 \\
<.10 \\
<.10\end{array}$ & $\begin{array}{l}<.002 \\
<.002 \\
<.002 \\
<.002 \\
<.002\end{array}$ & $\begin{array}{l}<.03 \\
<.03 \\
<.03 \\
<.03 \\
<.03\end{array}$ & $\begin{array}{l}<.06 \\
<.06 \\
<.06 \\
<.06 \\
<.06\end{array}$ & $\begin{array}{l}<.07 \\
<.07 \\
<.07 \\
<.07 \\
<.07\end{array}$ & $\begin{array}{l}<.04 \\
<.04 \\
<.04 \\
<.04 \\
<.04\end{array}$ \\
\hline $\begin{array}{l}390830102052001 \\
390838100411701 \\
391044100051001 \\
391921101385501\end{array}$ & $\begin{array}{l}<.10 \\
<.10 \\
<.10 \\
<.10\end{array}$ & $\begin{array}{l}<.007 \\
<.007 \\
<.007 \\
<.007\end{array}$ & $\begin{array}{l}<.013 \\
<.013 \\
<.013 \\
<.013\end{array}$ & $\begin{array}{l}<.002 \\
<.002 \\
<.002 \\
<.002\end{array}$ & $\begin{array}{l}<.001 \\
<.001 \\
<.001 \\
<.001\end{array}$ & $\begin{array}{l}<.07 \\
<.07 \\
<.07 \\
<.07\end{array}$ & $\begin{array}{l}<.10 \\
<.10 \\
<.10 \\
<.10\end{array}$ & $\begin{array}{l}<.002 \\
<.002 \\
<.002 \\
<.002\end{array}$ & $\begin{array}{l}<.03 \\
<.03 \\
<.03 \\
<.03\end{array}$ & $\begin{array}{l}<.06 \\
<.06 \\
<.06 \\
<.06\end{array}$ & $\begin{array}{l}<.07 \\
<.07 \\
<.07 \\
<.07\end{array}$ & $\begin{array}{l}<.04 \\
<.04 \\
<.04 \\
<.04\end{array}$ \\
\hline
\end{tabular}




\begin{tabular}{|c|c|c|c|c|c|c|c|c|c|c|c|c|}
\hline STATION NUMBER & $\begin{array}{l}\text { 1,1-DI } \\
\text { CHLORO- } \\
\text { PRO- } \\
\text { PENE, } \\
\text { WAT, WH } \\
\text { TOTAL } \\
\text { (UG/L) }\end{array}$ & $\begin{array}{c}\text { 123-TRI } \\
\text { CHLORO- } \\
\text { PROPANE } \\
\text { WATER } \\
\text { WHOLE } \\
\text { TOTAL } \\
\text { (UG/L) }\end{array}$ & $\begin{array}{c}1,2- \\
\text { DIBROMO } \\
\text { ETHANE } \\
\text { WATER } \\
\text { WHOLE } \\
\text { TOTAL } \\
\text { (UG/L) }\end{array}$ & $\begin{array}{c}\text { 1,2-DI- } \\
\text { CHLORO- } \\
\text { ETHANE } \\
\text { TOTAL } \\
\text { (UG/L) }\end{array}$ & $\begin{array}{c}1,2-D I- \\
\text { CHLORO- } \\
\text { PROPANE } \\
\text { TOTAL } \\
\text { (UG/L) }\end{array}$ & $\begin{array}{c}\text { TRANS- } \\
1,2-\text { DI- } \\
\text { CHLORO- } \\
\text { ETHENE } \\
\text { TOTAL } \\
\text { (UG/L) }\end{array}$ & $\begin{array}{c}2,2-\mathrm{DI} \\
\text { CHLORO- } \\
\text { PRO- } \\
\text { PANE } \\
\text { WAT, WH } \\
\text { TOTAL } \\
\text { (UG/L) }\end{array}$ & $\begin{array}{c}\text { 2BUTENE } \\
\text { TRANS-1 } \\
4-D I- \\
\text { CHLORO } \\
\text { UNFLTRD } \\
\text { RECOVER } \\
\text { (UG/L) }\end{array}$ & $\begin{array}{c}\text { 2-HEXA- } \\
\text { NONE } \\
\text { WATER } \\
\text { WHOLE } \\
\text { TOTAL } \\
\text { (UG/L) }\end{array}$ & $\begin{array}{l}\text { ACETONE } \\
\text { WATER } \\
\text { WHOLE } \\
\text { TOTAL } \\
\text { (UG/L) }\end{array}$ & $\begin{array}{l}\text { ACRYLO- } \\
\text { NITRILE } \\
\text { TOTAL } \\
\text { (UG/L) }\end{array}$ & $\begin{array}{c}1,2,3- \\
\text { TRI- } \\
\text { CHLORO } \\
\text { BENZENE } \\
\text { WAT, WH } \\
\text { REC } \\
\text { (UG/L) }\end{array}$ \\
\hline $\begin{array}{l}344800101324901 \\
345826100580501 \\
351656101161101 \\
351914101204401 \\
352035100293301\end{array}$ & $\begin{array}{l}<.03 \\
<.03 \\
<.03 \\
<.03 \\
<.03\end{array}$ & $\begin{array}{l}<.2 \\
<.2 \\
<.2 \\
<.2 \\
<.2\end{array}$ & $\begin{array}{l}<.04 \\
<.04 \\
<.04 \\
<.04 \\
<.04\end{array}$ & $\begin{array}{l}<.1 \\
<.1 \\
<.1 \\
<.1 \\
<.1\end{array}$ & $\begin{array}{l}<.07 \\
<.07 \\
<.07 \\
<.07 \\
<.07\end{array}$ & $\begin{array}{l}<.03 \\
<.03 \\
<.03 \\
<.03 \\
<.03\end{array}$ & $\begin{array}{l}<.08 \\
<.08 \\
<.08 \\
<.08 \\
<.08\end{array}$ & $\begin{array}{l}<.7 \\
<.7 \\
<.7 \\
<.7 \\
<.7\end{array}$ & $\begin{array}{l}<.7 \\
<.7 \\
<.7 \\
<.7 \\
<.7\end{array}$ & $\begin{array}{l}<5 \\
<5 \\
<5 \\
<5 \\
<5\end{array}$ & $\begin{array}{l}<1 \\
<1 \\
<1 \\
<1 \\
<1\end{array}$ & $\begin{array}{l}<.3 \\
<.3 \\
<.3 \\
<.3 \\
<.3\end{array}$ \\
\hline $\begin{array}{l}352249100425401 \\
352513101372101 \\
352909101084001 \\
353110100550401 \\
353941102350201\end{array}$ & $\begin{array}{l}<.03 \\
<.03 \\
<.03 \\
<.03 \\
<.03\end{array}$ & $\begin{array}{l}<.2 \\
<.2 \\
<.2 \\
<.2 \\
<.2\end{array}$ & $\begin{array}{l}<.04 \\
<.04 \\
<.04 \\
<.04 \\
<.04\end{array}$ & $\begin{array}{l}<.1 \\
<.1 \\
<.1 \\
<.1 \\
<.1\end{array}$ & $\begin{array}{l}<.07 \\
<.07 \\
<.07 \\
<.07 \\
<.07\end{array}$ & $\begin{array}{l}<.03 \\
<.03 \\
<.03 \\
<.03 \\
<.03\end{array}$ & $\begin{array}{l}<.08 \\
<.08 \\
<.08 \\
<.08 \\
<.08\end{array}$ & $\begin{array}{l}<.7 \\
<.7 \\
<.7 \\
<.7 \\
<.7\end{array}$ & $\begin{array}{l}<.7 \\
<.7 \\
<.7 \\
<.7 \\
<.7\end{array}$ & $\begin{array}{l}<5 \\
<5 \\
<5 \\
<5 \\
<5\end{array}$ & $\begin{array}{l}<1 \\
<1 \\
<1 \\
<1 \\
<1\end{array}$ & $\begin{array}{l}<.3 \\
<.3 \\
<.3 \\
<.3 \\
<.3\end{array}$ \\
\hline $\begin{array}{l}354248100501501 \\
354331102183601 \\
354348102543601 \\
354656099480301 \\
354728102295901\end{array}$ & $\begin{array}{l}<.03 \\
<.03 \\
<.03 \\
<.03 \\
<.03\end{array}$ & $\begin{array}{l}<.2 \\
<.2 \\
<.2 \\
<.2 \\
<.2\end{array}$ & $\begin{array}{l}<.04 \\
<.04 \\
<.04 \\
<.04 \\
<.04\end{array}$ & $\begin{array}{l}<.1 \\
<.1 \\
<.1 \\
<.1 \\
<.1\end{array}$ & $\begin{array}{l}<.07 \\
<.07 \\
<.07 \\
<.07 \\
<.07\end{array}$ & $\begin{array}{l}<.03 \\
<.03 \\
<.03 \\
<.03 \\
<.03\end{array}$ & $\begin{array}{l}<.08 \\
<.08 \\
<.08 \\
<.08 \\
<.08\end{array}$ & $\begin{array}{l}<.7 \\
<.7 \\
<.7 \\
<.7 \\
<.7\end{array}$ & $\begin{array}{l}<.7 \\
<.7 \\
<.7 \\
<.7 \\
<.7\end{array}$ & $\begin{array}{l}<5 \\
<5 \\
<5 \\
<5 \\
<5\end{array}$ & $\begin{array}{l}<1 \\
<1 \\
<1 \\
<1 \\
<1\end{array}$ & $\begin{array}{l}<.3 \\
<.3 \\
<.3 \\
<.3 \\
<.3\end{array}$ \\
\hline $\begin{array}{l}354918102020901 \\
355701100313001 \\
355852101274101 \\
355916103215201 \\
360703102361901\end{array}$ & $\begin{array}{l}<.03 \\
<.03 \\
<.03 \\
<.03 \\
<.03\end{array}$ & $\begin{array}{l}<.2 \\
<.2 \\
<.2 \\
<.2 \\
<.2\end{array}$ & $\begin{array}{l}<.04 \\
<.04 \\
<.04 \\
<.04 \\
<.04\end{array}$ & $\begin{array}{l}<.1 \\
<.1 \\
<.1 \\
<.1 \\
<.1\end{array}$ & $\begin{array}{l}<.07 \\
<.07 \\
<.07 \\
<.07 \\
<.07\end{array}$ & $\begin{array}{l}<.03 \\
<.03 \\
<.03 \\
<.03 \\
<.03\end{array}$ & $\begin{array}{l}<.08 \\
<.08 \\
<.08 \\
<.08 \\
<.08\end{array}$ & $\begin{array}{l}<.7 \\
<.7 \\
<.7 \\
<.7 \\
<.7\end{array}$ & $\begin{array}{l}<.7 \\
<.7 \\
<.7 \\
<.7 \\
<.7\end{array}$ & $\begin{array}{l}<5 \\
<5 \\
<5 \\
<5 \\
<5\end{array}$ & $\begin{array}{l}<1 \\
<1 \\
<1 \\
<1 \\
<1\end{array}$ & $\begin{array}{l}<.3 \\
<.3 \\
<.3 \\
<.3 \\
<.3\end{array}$ \\
\hline $\begin{array}{l}360838102560301 \\
360944100162101 \\
361014100221001 \\
361049100564901 \\
361054101393601\end{array}$ & $\begin{array}{l}<.03 \\
<.03 \\
<.03 \\
<.03 \\
<.03\end{array}$ & $\begin{array}{l}<.2 \\
<.2 \\
<.2 \\
<.2 \\
<.2\end{array}$ & $\begin{array}{l}<.04 \\
<.04 \\
<.04 \\
<.04 \\
<.04\end{array}$ & $\begin{array}{l}<.1 \\
<.1 \\
<.1 \\
<.1 \\
<.1\end{array}$ & $\begin{array}{l}<.07 \\
<.07 \\
<.07 \\
<.07 \\
<.07\end{array}$ & $\begin{array}{l}<.03 \\
<.03 \\
<.03 \\
<.03 \\
<.03\end{array}$ & $\begin{array}{l}<.08 \\
<.08 \\
<.08 \\
<.08 \\
<.08\end{array}$ & $\begin{array}{l}<.7 \\
<.7 \\
<.7 \\
<.7 \\
<.7\end{array}$ & $\begin{array}{l}<.7 \\
<.7 \\
<.7 \\
<.7 \\
<.7\end{array}$ & $\begin{array}{l}<5 \\
<5 \\
<5 \\
<5 \\
<5\end{array}$ & $\begin{array}{l}<1 \\
<1 \\
<1 \\
<1 \\
<1\end{array}$ & $\begin{array}{l}<.3 \\
<.3 \\
<.3 \\
<.3 \\
<.3\end{array}$ \\
\hline $\begin{array}{l}361114099420501 \\
361517102065301 \\
362115101173901 \\
362134102035101 \\
362615100435801\end{array}$ & $\begin{array}{l}<.03 \\
<.03 \\
<.03 \\
<.03 \\
<.03\end{array}$ & $\begin{array}{l}<.2 \\
<.2 \\
<.2 \\
<.2 \\
<.2\end{array}$ & $\begin{array}{l}<.04 \\
<.04 \\
<.04 \\
<.04 \\
<.04\end{array}$ & $\begin{array}{l}<.1 \\
<.1 \\
<.1 \\
<.1 \\
<.1\end{array}$ & $\begin{array}{l}<.07 \\
<.07 \\
<.07 \\
<.07 \\
<.07\end{array}$ & $\begin{array}{l}<.03 \\
<.03 \\
<.03 \\
<.03 \\
<.03\end{array}$ & $\begin{array}{l}<.08 \\
<.08 \\
<.08 \\
<.08 \\
<.08\end{array}$ & $\begin{array}{l}<.7 \\
<.7 \\
<.7 \\
<.7 \\
<.7\end{array}$ & $\begin{array}{l}<.7 \\
<.7 \\
<.7 \\
<.7 \\
<.7\end{array}$ & $\begin{array}{l}<5 \\
<5 \\
<5 \\
<5 \\
<5\end{array}$ & $\begin{array}{l}<1 \\
<1 \\
<1 \\
<1 \\
<1\end{array}$ & $\begin{array}{l}<.3 \\
<.3 \\
<.3 \\
<.3 \\
<.3\end{array}$ \\
\hline $\begin{array}{l}362744102334901 \\
363057101384701 \\
363104100035501 \\
363154099310401 \\
363157102565601\end{array}$ & $\begin{array}{l}<.03 \\
<.03 \\
<.03 \\
<.03 \\
<.03\end{array}$ & $\begin{array}{l}<.2 \\
<.2 \\
<.2 \\
<.2 \\
<.2\end{array}$ & $\begin{array}{l}<.04 \\
<.04 \\
<.04 \\
<.04 \\
<.04\end{array}$ & $\begin{array}{l}<.1 \\
<.1 \\
<.1 \\
<.1 \\
<.1\end{array}$ & $\begin{array}{l}<.07 \\
<.07 \\
<.07 \\
<.07 \\
<.07\end{array}$ & $\begin{array}{l}<.03 \\
<.03 \\
<.03 \\
<.03 \\
<.03\end{array}$ & $\begin{array}{l}<.08 \\
<.08 \\
<.08 \\
<.08 \\
<.08\end{array}$ & $\begin{array}{l}<.7 \\
<.7 \\
<.7 \\
<.7 \\
<.7\end{array}$ & $\begin{array}{l}<.7 \\
<.7 \\
<.7 \\
<.7 \\
<.7\end{array}$ & $\begin{array}{l}<5 \\
<5 \\
<5 \\
<5 \\
<5\end{array}$ & $\begin{array}{l}<1 \\
<1 \\
<1 \\
<1 \\
<1\end{array}$ & $\begin{array}{l}<.3 \\
<.3 \\
<.3 \\
<.3 \\
<.3\end{array}$ \\
\hline $\begin{array}{l}363239100301801 \\
363427102440401 \\
364219101394101 \\
364411102321201 \\
365223102113001\end{array}$ & $\begin{array}{l}<.03 \\
<.03 \\
<.03 \\
<.03 \\
<.03\end{array}$ & $\begin{array}{l}<.2 \\
<.2 \\
<.2 \\
<.2 \\
<.2\end{array}$ & $\begin{array}{l}<.04 \\
<.04 \\
<.04 \\
<.04 \\
<.04\end{array}$ & $\begin{array}{l}<.1 \\
<.1 \\
<.1 \\
<.1 \\
<.1\end{array}$ & $\begin{array}{l}<.07 \\
<.07 \\
<.07 \\
<.07 \\
<.07\end{array}$ & $\begin{array}{l}<.03 \\
<.03 \\
<.03 \\
<.03 \\
<.03\end{array}$ & $\begin{array}{l}<.08 \\
<.08 \\
<.08 \\
<.08 \\
<.08\end{array}$ & $\begin{array}{l}<.7 \\
<.7 \\
<.7 \\
<.7 \\
<.7\end{array}$ & $\begin{array}{l}<.7 \\
<.7 \\
<.7 \\
<.7 \\
<.7\end{array}$ & $\begin{array}{l}<5 \\
<5 \\
<5 \\
<5 \\
<5\end{array}$ & $\begin{array}{l}<1 \\
<1 \\
<1 \\
<1 \\
<1\end{array}$ & $\begin{array}{l}<.3 \\
<.3 \\
<.3 \\
<.3 \\
<.3\end{array}$ \\
\hline $\begin{array}{l}365422101083701 \\
365445100381901 \\
365821101375301 \\
365934101573001 \\
370358100510301\end{array}$ & $\begin{array}{l}<.03 \\
<.03 \\
<.03 \\
<.03 \\
<.03\end{array}$ & $\begin{array}{l}<.2 \\
<.2 \\
<.2 \\
<.2 \\
<.2\end{array}$ & $\begin{array}{l}<.04 \\
<.04 \\
<.04 \\
<.04 \\
<.04\end{array}$ & $\begin{array}{l}<.1 \\
<.1 \\
<.1 \\
<.1 \\
<.1\end{array}$ & $\begin{array}{l}<.07 \\
<.07 \\
<.07 \\
<.07 \\
<.07\end{array}$ & $\begin{array}{l}<.03 \\
<.03 \\
<.03 \\
<.03 \\
<.03\end{array}$ & $\begin{array}{l}<.08 \\
<.08 \\
<.08 \\
<.08 \\
<.08\end{array}$ & $\begin{array}{l}<.7 \\
<.7 \\
<.7 \\
<.7 \\
<.7\end{array}$ & $\begin{array}{l}<.7 \\
<.7 \\
<.7 \\
<.7 \\
<.7\end{array}$ & $\begin{array}{l}<5 \\
<5 \\
<5 \\
<5 \\
<5\end{array}$ & $\begin{array}{l}<1 \\
<1 \\
<1 \\
<1 \\
<1\end{array}$ & $\begin{array}{l}<.3 \\
<.3 \\
<.3 \\
<.3 \\
<.3\end{array}$ \\
\hline $\begin{array}{l}370458101514401 \\
370724100281601 \\
371738101220301 \\
372534100443501 \\
372649101344701\end{array}$ & $\begin{array}{l}<.03 \\
<.03 \\
<.03 \\
<.03 \\
<.03\end{array}$ & $\begin{array}{l}<.2 \\
<.2 \\
<.2 \\
<.2 \\
<.2\end{array}$ & $\begin{array}{l}<.04 \\
<.04 \\
<.04 \\
<.04 \\
<.04\end{array}$ & $\begin{array}{l}<.1 \\
<.1 \\
<.1 \\
<.1 \\
<.1\end{array}$ & $\begin{array}{l}<.07 \\
<.07 \\
<.07 \\
<.07 \\
<.07\end{array}$ & $\begin{array}{l}<.03 \\
<.03 \\
<.03 \\
<.03 \\
<.03\end{array}$ & $\begin{array}{l}<.08 \\
<.08 \\
<.08 \\
<.08 \\
<.08\end{array}$ & $\begin{array}{l}<.7 \\
<.7 \\
<.7 \\
<.7 \\
<.7\end{array}$ & $\begin{array}{l}<.7 \\
<.7 \\
<.7 \\
<.7 \\
<.7\end{array}$ & $\begin{array}{l}<5 \\
<5 \\
<5 \\
<5 \\
<5\end{array}$ & $\begin{array}{l}<1 \\
<1 \\
<1 \\
<1 \\
<1\end{array}$ & $\begin{array}{l}<.3 \\
<.3 \\
<.3 \\
<.3 \\
<.3\end{array}$ \\
\hline $\begin{array}{l}372956099512201 \\
373229101193201 \\
373345101070801 \\
373507102162001 \\
373527100312701\end{array}$ & $\begin{array}{l}<.03 \\
<.03 \\
<.03 \\
<.03 \\
<.03\end{array}$ & $\begin{array}{l}<.2 \\
<.2 \\
<.2 \\
<.2 \\
<.2\end{array}$ & $\begin{array}{l}<.04 \\
<.04 \\
<.04 \\
<.04 \\
<.04\end{array}$ & $\begin{array}{l}<.1 \\
<.1 \\
<.1 \\
<.1 \\
<.1\end{array}$ & $\begin{array}{l}<.07 \\
<.07 \\
<.07 \\
<.07 \\
<.07\end{array}$ & $\begin{array}{l}<.03 \\
<.03 \\
<.03 \\
<.03 \\
<.03\end{array}$ & $\begin{array}{l}<.08 \\
<.08 \\
<.08 \\
<.08 \\
<.08\end{array}$ & $\begin{array}{l}<.7 \\
<.7 \\
<.7 \\
<.7 \\
<.7\end{array}$ & $\begin{array}{l}<.7 \\
<.7 \\
<.7 \\
<.7 \\
<.7\end{array}$ & $\begin{array}{l}<5 \\
<5 \\
<5 \\
<5 \\
<5\end{array}$ & $\begin{array}{l}<1 \\
<1 \\
<1 \\
<1 \\
<1\end{array}$ & $\begin{array}{l}<.3 \\
<.3 \\
<.3 \\
<.3 \\
<.3\end{array}$ \\
\hline $\begin{array}{l}373559102314901 \\
373732099291201 \\
374535102110301 \\
374650100181901 \\
375129100532301\end{array}$ & $\begin{array}{l}<.03 \\
<.03 \\
<.03 \\
<.03 \\
<.03\end{array}$ & $\begin{array}{l}<.2 \\
<.2 \\
<.2 \\
<.2 \\
<.2\end{array}$ & $\begin{array}{l}<.04 \\
<.04 \\
<.04 \\
<.04 \\
<.04\end{array}$ & $\begin{array}{l}<.1 \\
<.1 \\
<.1 \\
<.1 \\
<.1\end{array}$ & $\begin{array}{l}<.07 \\
<.07 \\
<.07 \\
<.07 \\
<.07\end{array}$ & $\begin{array}{l}<.03 \\
<.03 \\
<.03 \\
<.03 \\
<.03\end{array}$ & $\begin{array}{l}<.08 \\
<.08 \\
<.08 \\
<.08 \\
<.08\end{array}$ & $\begin{array}{l}<.7 \\
<.7 \\
<.7 \\
<.7 \\
<.7\end{array}$ & $\begin{array}{l}<.7 \\
<.7 \\
<.7 \\
<.7 \\
<.7\end{array}$ & $\begin{array}{l}<5 \\
<5 \\
<5 \\
<5 \\
<5\end{array}$ & $\begin{array}{l}<1 \\
<1 \\
<1 \\
<1 \\
<1\end{array}$ & $\begin{array}{l}<.3 \\
<.3 \\
<.3 \\
<.3 \\
<.3\end{array}$ \\
\hline $\begin{array}{l}375447099245001 \\
375828101111801 \\
380331100352801 \\
382947100443201 \\
383008101315601\end{array}$ & $\begin{array}{l}<.03 \\
<.03 \\
<.03 \\
<.03 \\
<.03\end{array}$ & $\begin{array}{l}<.2 \\
<.2 \\
<.2 \\
<.2 \\
<.2\end{array}$ & $\begin{array}{l}<.04 \\
<.04 \\
<.04 \\
<.04 \\
<.04\end{array}$ & $\begin{array}{l}<.1 \\
<.1 \\
<.1 \\
<.1 \\
<.1\end{array}$ & $\begin{array}{l}<.07 \\
<.07 \\
<.07 \\
<.07 \\
<.07\end{array}$ & $\begin{array}{l}<.03 \\
<.03 \\
<.03 \\
<.03 \\
<.03\end{array}$ & $\begin{array}{l}<.08 \\
<.08 \\
<.08 \\
<.08 \\
<.08\end{array}$ & $\begin{array}{l}<.7 \\
<.7 \\
<.7 \\
<.7 \\
<.7\end{array}$ & $\begin{array}{l}<.7 \\
<.7 \\
<.7 \\
<.7 \\
<.7\end{array}$ & $\begin{array}{l}<5 \\
<5 \\
<5 \\
<5 \\
<5\end{array}$ & $\begin{array}{l}<1 \\
<1 \\
<1 \\
<1 \\
<1\end{array}$ & $\begin{array}{l}<.3 \\
<.3 \\
<.3 \\
<.3 \\
<.3\end{array}$ \\
\hline $\begin{array}{l}383758101195801 \\
383919101040101 \\
385210100164501 \\
385904099522201 \\
390622101003201\end{array}$ & $\begin{array}{l}<.03 \\
<.03 \\
<.03 \\
<.03 \\
<.03\end{array}$ & $\begin{array}{l}<.2 \\
<.2 \\
<.2 \\
<.2 \\
<.2\end{array}$ & $\begin{array}{l}<.04 \\
<.04 \\
<.04 \\
<.04 \\
<.04\end{array}$ & $\begin{array}{l}<.1 \\
<.1 \\
<.1 \\
<.1 \\
<.1\end{array}$ & $\begin{array}{l}<.07 \\
<.07 \\
<.07 \\
<.07 \\
<.07\end{array}$ & $\begin{array}{l}<.03 \\
<.03 \\
<.03 \\
<.03 \\
<.03\end{array}$ & $\begin{array}{l}<.08 \\
<.08 \\
<.08 \\
<.08 \\
<.08\end{array}$ & $\begin{array}{l}<.7 \\
<.7 \\
<.7 \\
<.7 \\
<.7\end{array}$ & $\begin{array}{l}<.7 \\
<.7 \\
<.7 \\
<.7 \\
<.7\end{array}$ & $\begin{array}{l}<5 \\
<5 \\
<5 \\
<5 \\
<5\end{array}$ & $\begin{array}{l}<1 \\
<1 \\
<1 \\
<1 \\
<1\end{array}$ & $\begin{array}{l}<.3 \\
<.3 \\
<.3 \\
<.3 \\
<.3\end{array}$ \\
\hline $\begin{array}{l}390830102052001 \\
390838100411701 \\
391044100051001 \\
391921101385501\end{array}$ & $\begin{array}{l}<.03 \\
<.03 \\
<.03 \\
<.03\end{array}$ & $\begin{array}{l}<.2 \\
<.2 \\
<.2 \\
<.2\end{array}$ & $\begin{array}{l}<.04 \\
<.04 \\
<.04 \\
<.04\end{array}$ & $\begin{array}{l}<.1 \\
<.1 \\
<.1 \\
<.1\end{array}$ & $\begin{array}{l}<.07 \\
<.07 \\
<.07 \\
<.07\end{array}$ & $\begin{array}{l}<.03 \\
<.03 \\
<.03 \\
<.03\end{array}$ & $\begin{array}{l}<.08 \\
<.08 \\
<.08 \\
<.08\end{array}$ & $\begin{array}{l}<.7 \\
<.7 \\
<.7 \\
<.7\end{array}$ & $\begin{array}{l}<.7 \\
<.7 \\
<.7 \\
<.7\end{array}$ & $\begin{array}{l}<5 \\
<5 \\
<5 \\
<5\end{array}$ & $\begin{array}{l}<1 \\
<1 \\
<1 \\
<1\end{array}$ & $\begin{array}{l}<.3 \\
<.3 \\
<.3 \\
<.3\end{array}$ \\
\hline
\end{tabular}




\begin{tabular}{|c|c|c|c|c|c|c|c|c|c|c|c|c|}
\hline STATION NUMBER & $\begin{array}{l}\text { BENZENE } \\
\text { 123-TRI } \\
\text { METHYL- } \\
\text { WATER } \\
\text { UNFLTRD } \\
\text { RECOVER } \\
\text { (UG/L) }\end{array}$ & $\begin{array}{c}\text { BENZENE } \\
1,2,4- \\
\text { TRI- } \\
\text { CHLORO- } \\
\text { WAT UNF } \\
\text { REC } \\
\text { (UG/L) }\end{array}$ & $\begin{array}{l}\text { BENZENE } \\
\text { 124-TRI } \\
\text { METHYL } \\
\text { UNFILT } \\
\text { RECOVER } \\
\text { (UG/L) }\end{array}$ & $\begin{array}{c}\text { BENZENE } \\
\text { 135-TRI } \\
\text { METHYL } \\
\text { WATER } \\
\text { UNELTRD } \\
\text { REC } \\
\text { (UG/L) }\end{array}$ & $\begin{array}{c}\text { BENZENE } \\
1,3-D I- \\
\text { CHLORO- } \\
\text { WATER } \\
\text { UNFLTRD } \\
\text { REC } \\
\text { (UG/L) }\end{array}$ & $\begin{array}{c}\text { BENZENE } \\
1,4-D I- \\
\text { CHLORO- } \\
\text { WATER } \\
\text { UNFLTRD } \\
\text { REC } \\
\text { (UG/L) }\end{array}$ & $\begin{array}{l}\text { ISO- } \\
\text { PROPYL- } \\
\text { BENZENE } \\
\text { WATER } \\
\text { WHOLE } \\
\text { REC } \\
\text { (UG/L) }\end{array}$ & $\begin{array}{c}\text { BENZENE } \\
\text { N-BUTYL } \\
\text { WATER } \\
\text { UNFLTRD } \\
\text { REC } \\
\text { (UG/L) }\end{array}$ & $\begin{array}{c}\text { BENZENE } \\
\text { N-PROPY } \\
\text { WATER } \\
\text { UNFLTRD } \\
\text { REC } \\
\text { (UG/L) }\end{array}$ & $\begin{array}{c}\text { BENZENE } \\
\text { O-DI- } \\
\text { CHLORO- } \\
\text { WATER } \\
\text { UNELTRD } \\
\text { REC } \\
\text { (UG/L) }\end{array}$ & $\begin{array}{l}\text { BENZENE } \\
\text { SEC } \\
\text { BUTYL- } \\
\text { WATER } \\
\text { UNFLTRD } \\
\text { REC } \\
\text { (UG/L) }\end{array}$ & $\begin{array}{c}\text { BENZENE } \\
\text { TERT- } \\
\text { BUTYL- } \\
\text { WATER } \\
\text { UNELTRD } \\
\text { REC } \\
\text { (UG/L) }\end{array}$ \\
\hline $\begin{array}{l}344800101324901 \\
345826100580501 \\
351656101161101 \\
351914101204401 \\
352035100293301\end{array}$ & $\begin{array}{l}<.1 \\
<.1 \\
<.1 \\
<.1 \\
<.1\end{array}$ & $\begin{array}{l}<.2 \\
<.2 \\
<.2 \\
<.2 \\
<.2\end{array}$ & $\begin{array}{l}<.06 \\
<.06 \\
<.06 \\
<.06 \\
<.06\end{array}$ & $\begin{array}{l}<.04 \\
<.04 \\
<.04 \\
<.04 \\
<.04\end{array}$ & $\begin{array}{l}<.05 \\
<.05 \\
<.05 \\
<.05 \\
<.05\end{array}$ & $\begin{array}{l}<.05 \\
<.05 \\
<.05 \\
<.05 \\
<.05\end{array}$ & $\begin{array}{l}<.03 \\
<.03 \\
<.03 \\
<.03 \\
<.03\end{array}$ & $\begin{array}{l}<.2 \\
<.2 \\
<.2 \\
<.2 \\
<.2\end{array}$ & $\begin{array}{l}<.04 \\
<.04 \\
<.04 \\
<.04 \\
<.04\end{array}$ & $\begin{array}{l}<.05 \\
<.05 \\
<.05 \\
<.05 \\
<.05\end{array}$ & $\begin{array}{l}<.05 \\
<.05 \\
<.05 \\
<.05 \\
<.05\end{array}$ & $\begin{array}{l}<.10 \\
<.10 \\
<.10 \\
<.10 \\
<.10\end{array}$ \\
\hline $\begin{array}{l}352249100425401 \\
352513101372101 \\
352909101084001 \\
353110100550401 \\
353941102350201\end{array}$ & $\begin{array}{l}<.1 \\
<.1 \\
<.1 \\
<.1 \\
<.1\end{array}$ & $\begin{array}{l}<.2 \\
<.2 \\
<.2 \\
<.2 \\
<.2\end{array}$ & $\begin{array}{l}<.06 \\
<.06 \\
<.06 \\
<.06 \\
<.06\end{array}$ & $\begin{array}{l}<.04 \\
<.04 \\
<.04 \\
<.04 \\
<.04\end{array}$ & $\begin{array}{l}<.05 \\
<.05 \\
<.05 \\
<.05 \\
<.05\end{array}$ & $\begin{array}{l}<.05 \\
<.05 \\
<.05 \\
<.05 \\
<.05\end{array}$ & $\begin{array}{l}<.03 \\
<.03 \\
<.03 \\
<.03 \\
<.03\end{array}$ & $\begin{array}{l}<.2 \\
<.2 \\
<.2 \\
<.2 \\
<.2\end{array}$ & $\begin{array}{l}<.04 \\
<.04 \\
<.04 \\
<.04 \\
<.04\end{array}$ & $\begin{array}{l}<.05 \\
<.05 \\
<.05 \\
<.05 \\
<.05\end{array}$ & $\begin{array}{l}<.05 \\
<.05 \\
<.05 \\
<.05 \\
<.05\end{array}$ & $\begin{array}{l}<.10 \\
<.10 \\
<.10 \\
<.10 \\
<.10\end{array}$ \\
\hline $\begin{array}{l}354248100501501 \\
354331102183601 \\
354348102543601 \\
354656099480301 \\
354728102295901\end{array}$ & $\begin{array}{l}<.1 \\
<.1 \\
<.1 \\
<.1 \\
<.1\end{array}$ & $\begin{array}{l}<.2 \\
<.2 \\
<.2 \\
<.2 \\
<.2\end{array}$ & $\begin{array}{l}<.06 \\
<.06 \\
<.06 \\
<.06 \\
<.06\end{array}$ & $\begin{array}{l}<.04 \\
<.04 \\
<.04 \\
<.04 \\
<.04\end{array}$ & $\begin{array}{l}<.05 \\
<.05 \\
<.05 \\
<.05 \\
<.05\end{array}$ & $\begin{array}{l}<.05 \\
<.05 \\
<.05 \\
<.05 \\
<.05\end{array}$ & $\begin{array}{l}<.03 \\
<.03 \\
<.03 \\
<.03 \\
<.03\end{array}$ & $\begin{array}{l}<.2 \\
<.2 \\
<.2 \\
<.2 \\
<.2\end{array}$ & $\begin{array}{l}<.04 \\
<.04 \\
<.04 \\
<.04 \\
<.04\end{array}$ & $\begin{array}{l}<.05 \\
<.05 \\
<.05 \\
<.05 \\
<.05\end{array}$ & $\begin{array}{l}<.05 \\
<.05 \\
<.05 \\
<.05 \\
<.05\end{array}$ & $\begin{array}{l}<.10 \\
<.10 \\
<.10 \\
<.10 \\
<.10\end{array}$ \\
\hline $\begin{array}{l}354918102020901 \\
355701100313001 \\
355852101274101 \\
355916103215201 \\
360703102361901\end{array}$ & $\begin{array}{l}<.1 \\
<.1 \\
<.1 \\
<.1 \\
<.1\end{array}$ & $\begin{array}{l}<.2 \\
<.2 \\
<.2 \\
<.2 \\
<.2\end{array}$ & $\begin{array}{l}<.06 \\
<.06 \\
<.06 \\
<.06 \\
<.06\end{array}$ & $\begin{array}{l}<.04 \\
<.04 \\
<.04 \\
<.04 \\
<.04\end{array}$ & $\begin{array}{l}<.05 \\
<.05 \\
<.05 \\
<.05 \\
<.05\end{array}$ & $\begin{array}{l}<.05 \\
<.05 \\
<.05 \\
<.05 \\
<.05\end{array}$ & $\begin{array}{l}<.03 \\
<.03 \\
<.03 \\
<.03 \\
<.03\end{array}$ & $\begin{array}{l}<.2 \\
<.2 \\
<.2 \\
<.2 \\
<.2\end{array}$ & $\begin{array}{l}<.04 \\
<.04 \\
<.04 \\
<.04 \\
<.04\end{array}$ & $\begin{array}{l}<.05 \\
<.05 \\
<.05 \\
<.05 \\
<.05\end{array}$ & $\begin{array}{l}<.05 \\
<.05 \\
<.05 \\
<.05 \\
<.05\end{array}$ & $\begin{array}{l}<.10 \\
<.10 \\
<.10 \\
<.10 \\
<.10\end{array}$ \\
\hline $\begin{array}{l}360838102560301 \\
360944100162101 \\
361014100221001 \\
361049100564901 \\
361054101393601\end{array}$ & $\begin{array}{l}<.1 \\
<.1 \\
<.1 \\
<.1 \\
<.1\end{array}$ & $\begin{array}{l}<.2 \\
<.2 \\
<.2 \\
<.2 \\
<.2\end{array}$ & $\begin{array}{l}<.06 \\
<.06 \\
<.06 \\
<.06 \\
<.06\end{array}$ & $\begin{array}{l}<.04 \\
<.04 \\
<.04 \\
<.04 \\
<.04\end{array}$ & $\begin{array}{l}<.05 \\
<.05 \\
<.05 \\
<.05 \\
<.05\end{array}$ & $\begin{array}{l}<.05 \\
<.05 \\
<.05 \\
<.05 \\
<.05\end{array}$ & $\begin{array}{l}<.03 \\
<.03 \\
<.03 \\
<.03 \\
<.03\end{array}$ & $\begin{array}{l}<.2 \\
<.2 \\
<.2 \\
<.2 \\
<.2\end{array}$ & $\begin{array}{l}<.04 \\
<.04 \\
<.04 \\
<.04 \\
<.04\end{array}$ & $\begin{array}{l}<.05 \\
<.05 \\
<.05 \\
<.05 \\
<.05\end{array}$ & $\begin{array}{l}<.05 \\
<.05 \\
<.05 \\
<.05 \\
<.05\end{array}$ & $\begin{array}{l}<.10 \\
<.10 \\
<.10 \\
<.10 \\
<.10\end{array}$ \\
\hline $\begin{array}{l}361114099420501 \\
361517102065301 \\
362115101173901 \\
362134102035101 \\
362615100435801\end{array}$ & $\begin{array}{l}<.1 \\
<.1 \\
<.1 \\
<.1 \\
<.1\end{array}$ & $\begin{array}{l}<.2 \\
<.2 \\
<.2 \\
<.2 \\
<.2\end{array}$ & $\begin{array}{l}<.06 \\
<.06 \\
<.06 \\
<.06 \\
<.06\end{array}$ & $\begin{array}{l}<.04 \\
<.04 \\
<.04 \\
<.04 \\
<.04\end{array}$ & $\begin{array}{l}<.05 \\
<.05 \\
<.05 \\
<.05 \\
<.05\end{array}$ & $\begin{array}{l}<.05 \\
<.05 \\
<.05 \\
<.05 \\
<.05\end{array}$ & $\begin{array}{l}<.03 \\
<.03 \\
<.03 \\
<.03 \\
<.03\end{array}$ & $\begin{array}{l}<.2 \\
<.2 \\
<.2 \\
<.2 \\
<.2\end{array}$ & $\begin{array}{l}<.04 \\
<.04 \\
<.04 \\
<.04 \\
<.04\end{array}$ & $\begin{array}{l}<.05 \\
<.05 \\
<.05 \\
<.05 \\
<.05\end{array}$ & $\begin{array}{l}<.05 \\
<.05 \\
<.05 \\
<.05 \\
<.05\end{array}$ & $\begin{array}{l}<.10 \\
<.10 \\
<.10 \\
<.10 \\
<.10\end{array}$ \\
\hline $\begin{array}{l}362744102334901 \\
363057101384701 \\
363104100035501 \\
363154099310401 \\
363157102565601\end{array}$ & $\begin{array}{l}<.1 \\
<.1 \\
<.1 \\
<.1 \\
<.1\end{array}$ & $\begin{array}{l}<.2 \\
<.2 \\
<.2 \\
<.2 \\
<.2\end{array}$ & $\begin{array}{l}<.06 \\
<.06 \\
<.06 \\
<.06 \\
<.06\end{array}$ & $\begin{array}{l}<.04 \\
<.04 \\
<.04 \\
<.04 \\
<.04\end{array}$ & $\begin{array}{l}<.05 \\
<.05 \\
<.05 \\
<.05 \\
<.05\end{array}$ & $\begin{array}{l}\text { E. } 08 \\
<.05 \\
<.05 \\
<.05 \\
<.05\end{array}$ & $\begin{array}{l}<.03 \\
<.03 \\
<.03 \\
<.03 \\
<.03\end{array}$ & $\begin{array}{l}<.2 \\
<.2 \\
<.2 \\
<.2 \\
<.2\end{array}$ & $\begin{array}{l}<.04 \\
<.04 \\
<.04 \\
<.04 \\
<.04\end{array}$ & $\begin{array}{l}1.50 \\
<.05 \\
<.05 \\
<.05 \\
<.05\end{array}$ & $\begin{array}{l}<.05 \\
<.05 \\
<.05 \\
<.05 \\
<.05\end{array}$ & $\begin{array}{l}<.10 \\
<.10 \\
<.10 \\
<.10 \\
<.10\end{array}$ \\
\hline $\begin{array}{l}363239100301801 \\
363427102440401 \\
364219101394101 \\
364411102321201 \\
365223102113001\end{array}$ & $\begin{array}{l}<.1 \\
<.1 \\
<.1 \\
<.1 \\
<.1\end{array}$ & $\begin{array}{l}<.2 \\
<.2 \\
<.2 \\
<.2 \\
<.2\end{array}$ & $\begin{array}{l}<.06 \\
<.06 \\
<.06 \\
<.06 \\
<.06\end{array}$ & $\begin{array}{l}<.04 \\
<.04 \\
<.04 \\
<.04 \\
<.04\end{array}$ & $\begin{array}{l}<.05 \\
<.05 \\
<.05 \\
<.05 \\
<.05\end{array}$ & $\begin{array}{l}<.05 \\
<.05 \\
<.05 \\
<.05 \\
<.05\end{array}$ & $\begin{array}{l}<.03 \\
<.03 \\
<.03 \\
<.03 \\
<.03\end{array}$ & $\begin{array}{l}<.2 \\
<.2 \\
<.2 \\
<.2 \\
<.2\end{array}$ & $\begin{array}{l}<.04 \\
<.04 \\
<.04 \\
<.04 \\
<.04\end{array}$ & $\begin{array}{l}<.05 \\
<.05 \\
<.05 \\
<.05 \\
<.05\end{array}$ & $\begin{array}{l}<.05 \\
<.05 \\
<.05 \\
<.05 \\
<.05\end{array}$ & $\begin{array}{l}<.10 \\
<.10 \\
<.10 \\
<.10 \\
<.10\end{array}$ \\
\hline $\begin{array}{l}365422101083701 \\
365445100381901 \\
365821101375301 \\
365934101573001 \\
370358100510301\end{array}$ & $\begin{array}{l}<.1 \\
<.1 \\
<.1 \\
<.1 \\
<.1\end{array}$ & $\begin{array}{l}<.2 \\
<.2 \\
<.2 \\
<.2 \\
<.2\end{array}$ & $\begin{array}{l}<.06 \\
<.06 \\
<.06 \\
<.06 \\
<.06\end{array}$ & $\begin{array}{l}<.04 \\
<.04 \\
<.04 \\
<.04 \\
<.04\end{array}$ & $\begin{array}{l}<.05 \\
<.05 \\
<.05 \\
<.05 \\
<.05\end{array}$ & $\begin{array}{l}<.05 \\
<.05 \\
<.05 \\
<.05 \\
<.05\end{array}$ & $\begin{array}{l}<.03 \\
<.03 \\
<.03 \\
<.03 \\
<.03\end{array}$ & $\begin{array}{l}<.2 \\
<.2 \\
<.2 \\
<.2 \\
<.2\end{array}$ & $\begin{array}{l}<.04 \\
<.04 \\
<.04 \\
<.04 \\
<.04\end{array}$ & $\begin{array}{l}<.05 \\
<.05 \\
<.05 \\
<.05 \\
<.05\end{array}$ & $\begin{array}{l}<.05 \\
<.05 \\
<.05 \\
<.05 \\
<.05\end{array}$ & $\begin{array}{l}<.10 \\
<.10 \\
<.10 \\
<.10 \\
<.10\end{array}$ \\
\hline $\begin{array}{l}370458101514401 \\
370724100281601 \\
371738101220301 \\
372534100443501 \\
372649101344701\end{array}$ & $\begin{array}{l}<.1 \\
<.1 \\
<.1 \\
<.1 \\
<.1\end{array}$ & $\begin{array}{l}<.2 \\
<.2 \\
<.2 \\
<.2 \\
<.2\end{array}$ & $\begin{array}{l}<.06 \\
<.06 \\
<.06 \\
<.06 \\
<.06\end{array}$ & $\begin{array}{l}<.04 \\
<.04 \\
<.04 \\
<.04 \\
<.04\end{array}$ & $\begin{array}{l}<.05 \\
<.05 \\
<.05 \\
<.05 \\
<.05\end{array}$ & $\begin{array}{l}<.05 \\
<.05 \\
<.05 \\
<.05 \\
<.05\end{array}$ & $\begin{array}{l}<.03 \\
<.03 \\
<.03 \\
<.03 \\
<.03\end{array}$ & $\begin{array}{l}<.2 \\
<.2 \\
<.2 \\
<.2 \\
<.2\end{array}$ & $\begin{array}{l}<.04 \\
<.04 \\
<.04 \\
<.04 \\
<.04\end{array}$ & $\begin{array}{l}<.05 \\
<.05 \\
<.05 \\
<.05 \\
<.05\end{array}$ & $\begin{array}{l}<.05 \\
<.05 \\
<.05 \\
<.05 \\
<.05\end{array}$ & $\begin{array}{l}<.10 \\
<.10 \\
<.10 \\
<.10 \\
<.10\end{array}$ \\
\hline $\begin{array}{l}372956099512201 \\
373229101193201 \\
373345101070801 \\
373507102162001 \\
373527100312701\end{array}$ & $\begin{array}{l}<.1 \\
<.1 \\
<.1 \\
<.1 \\
<.1\end{array}$ & $\begin{array}{l}<.2 \\
<.2 \\
<.2 \\
<.2 \\
<.2\end{array}$ & $\begin{array}{l}<.06 \\
<.06 \\
<.06 \\
<.06 \\
<.06\end{array}$ & $\begin{array}{l}<.04 \\
<.04 \\
<.04 \\
<.04 \\
<.04\end{array}$ & $\begin{array}{l}<.05 \\
<.05 \\
<.05 \\
<.05 \\
<.05\end{array}$ & $\begin{array}{l}<.05 \\
<.05 \\
<.05 \\
<.05 \\
<.05\end{array}$ & $\begin{array}{l}<.03 \\
<.03 \\
<.03 \\
<.03 \\
<.03\end{array}$ & $\begin{array}{l}<.2 \\
<.2 \\
<.2 \\
<.2 \\
<.2\end{array}$ & $\begin{array}{l}<.04 \\
<.04 \\
<.04 \\
<.04 \\
<.04\end{array}$ & $\begin{array}{l}<.05 \\
<.05 \\
<.05 \\
<.05 \\
<.05\end{array}$ & $\begin{array}{l}<.05 \\
<.05 \\
<.05 \\
<.05 \\
<.05\end{array}$ & $\begin{array}{l}<.10 \\
<.10 \\
<.10 \\
<.10 \\
<.10\end{array}$ \\
\hline $\begin{array}{l}373559102314901 \\
373732099291201 \\
374535102110301 \\
374650100181901 \\
375129100532301\end{array}$ & $\begin{array}{l}<.1 \\
<.1 \\
<.1 \\
<.1 \\
<.1\end{array}$ & $\begin{array}{l}<.2 \\
<.2 \\
<.2 \\
<.2 \\
<.2\end{array}$ & $\begin{array}{l}<.06 \\
<.06 \\
<.06 \\
<.06 \\
<.06\end{array}$ & $\begin{array}{l}<.04 \\
<.04 \\
<.04 \\
<.04 \\
<.04\end{array}$ & $\begin{array}{l}<.05 \\
<.05 \\
<.05 \\
<.05 \\
<.05\end{array}$ & $\begin{array}{l}<.05 \\
<.05 \\
<.05 \\
<.05 \\
<.05\end{array}$ & $\begin{array}{l}<.03 \\
<.03 \\
<.03 \\
<.03 \\
<.03\end{array}$ & $\begin{array}{l}<.2 \\
<.2 \\
<.2 \\
<.2 \\
<.2\end{array}$ & $\begin{array}{l}<.04 \\
<.04 \\
<.04 \\
<.04 \\
<.04\end{array}$ & $\begin{array}{l}<.05 \\
<.05 \\
<.05 \\
<.05 \\
<.05\end{array}$ & $\begin{array}{l}<.05 \\
<.05 \\
<.05 \\
<.05 \\
<.05\end{array}$ & $\begin{array}{l}<.10 \\
<.10 \\
<.10 \\
<.10 \\
<.10\end{array}$ \\
\hline $\begin{array}{l}375447099245001 \\
375828101111801 \\
380331100352801 \\
382947100443201 \\
383008101315601\end{array}$ & $\begin{array}{l}<.1 \\
<.1 \\
<.1 \\
<.1 \\
<.1\end{array}$ & $\begin{array}{l}<.2 \\
<.2 \\
<.2 \\
<.2 \\
<.2\end{array}$ & $\begin{array}{l}<.06 \\
<.06 \\
<.06 \\
<.06 \\
<.06\end{array}$ & $\begin{array}{l}<.04 \\
<.04 \\
<.04 \\
<.04 \\
<.04\end{array}$ & $\begin{array}{l}<.05 \\
<.05 \\
<.05 \\
<.05 \\
<.05\end{array}$ & $\begin{array}{l}<.05 \\
<.05 \\
<.05 \\
<.05 \\
<.05\end{array}$ & $\begin{array}{l}<.03 \\
<.03 \\
<.03 \\
<.03 \\
<.03\end{array}$ & $\begin{array}{l}<.2 \\
<.2 \\
<.2 \\
<.2 \\
<.2\end{array}$ & $\begin{array}{l}<.04 \\
<.04 \\
<.04 \\
<.04 \\
<.04\end{array}$ & $\begin{array}{l}<.05 \\
<.05 \\
<.05 \\
<.05 \\
<.05\end{array}$ & $\begin{array}{l}<.05 \\
<.05 \\
<.05 \\
<.05 \\
<.05\end{array}$ & $\begin{array}{l}<.10 \\
<.10 \\
<.10 \\
<.10 \\
<.10\end{array}$ \\
\hline $\begin{array}{l}383758101195801 \\
383919101040101 \\
385210100164501 \\
385904099522201 \\
390622101003201\end{array}$ & $\begin{array}{l}<.1 \\
<.1 \\
<.1 \\
<.1 \\
<.1\end{array}$ & $\begin{array}{l}<.2 \\
<.2 \\
<.2 \\
<.2 \\
<.2\end{array}$ & $\begin{array}{l}<.06 \\
<.06 \\
<.06 \\
<.06 \\
<.06\end{array}$ & $\begin{array}{l}<.04 \\
<.04 \\
<.04 \\
<.04 \\
<.04\end{array}$ & $\begin{array}{l}<.05 \\
<.05 \\
<.05 \\
<.05 \\
<.05\end{array}$ & $\begin{array}{l}<.05 \\
<.05 \\
<.05 \\
<.05 \\
<.05\end{array}$ & $\begin{array}{l}<.03 \\
<.03 \\
<.03 \\
<.03 \\
<.03\end{array}$ & $\begin{array}{l}<.2 \\
<.2 \\
<.2 \\
<.2 \\
<.2\end{array}$ & $\begin{array}{l}<.04 \\
<.04 \\
<.04 \\
<.04 \\
<.04\end{array}$ & $\begin{array}{l}<.05 \\
<.05 \\
<.05 \\
<.05 \\
<.05\end{array}$ & $\begin{array}{l}<.05 \\
<.05 \\
<.05 \\
<.05 \\
<.05\end{array}$ & $\begin{array}{l}<.10 \\
<.10 \\
<.10 \\
<.10 \\
<.10\end{array}$ \\
\hline $\begin{array}{l}390830102052001 \\
390838100411701 \\
391044100051001 \\
391921101385501\end{array}$ & $\begin{array}{l}<.1 \\
<.1 \\
<.1 \\
<.1\end{array}$ & $\begin{array}{l}<.2 \\
<.2 \\
<.2 \\
<.2\end{array}$ & $\begin{array}{l}<.06 \\
<.06 \\
<.06 \\
<.06\end{array}$ & $\begin{array}{l}<.04 \\
<.04 \\
<.04 \\
<.04\end{array}$ & $\begin{array}{l}<.05 \\
<.05 \\
<.05 \\
<.05\end{array}$ & $\begin{array}{l}<.05 \\
<.05 \\
<.05 \\
<.05\end{array}$ & $\begin{array}{l}<.03 \\
<.03 \\
<.03 \\
<.03\end{array}$ & $\begin{array}{l}<.2 \\
<.2 \\
<.2 \\
<.2\end{array}$ & $\begin{array}{l}<.04 \\
<.04 \\
<.04 \\
<.04\end{array}$ & $\begin{array}{l}<.05 \\
<.05 \\
<.05 \\
<.05\end{array}$ & $\begin{array}{l}<.05 \\
<.05 \\
<.05 \\
<.05\end{array}$ & $\begin{array}{l}<.10 \\
<.10 \\
<.10 \\
<.10\end{array}$ \\
\hline
\end{tabular}


Appendix 1. Water-quality data from 74 domestic water-supply wells completed in the central High Plains aquifer-Continued

\begin{tabular}{|c|c|c|c|c|c|c|c|c|c|c|c|c|}
\hline STATION NUMBER & $\begin{array}{c}\text { BENZENE } \\
\text { TOTAL } \\
\text { (UG/L) }\end{array}$ & $\begin{array}{l}\text { BROMO- } \\
\text { BENZENE } \\
\text { WATER, } \\
\text { WHOLE, } \\
\text { TOTAL } \\
\text { (UG/L) }\end{array}$ & $\begin{array}{c}\text { BROMO- } \\
\text { ETHENE } \\
\text { WATER } \\
\text { UNFLTRD } \\
\text { RECOVER } \\
\text { (UG/L) }\end{array}$ & $\begin{array}{l}\text { BROMO- } \\
\text { FORM } \\
\text { TOTAL } \\
\text { (UG/L) }\end{array}$ & $\begin{array}{l}\text { CARBON } \\
\text { DI- } \\
\text { SULFIDE } \\
\text { WATER } \\
\text { WHOLE } \\
\text { TOTAL } \\
\text { (UG/L) }\end{array}$ & $\begin{array}{l}\text { CARBON } \\
\text { TETRA- } \\
\text { CHLO- } \\
\text { RIDE } \\
\text { TOTAL } \\
\text { (UG/L) }\end{array}$ & $\begin{array}{l}\text { CHLORO- } \\
\text { BENZENE } \\
\text { TOTAL } \\
\text { (UG/L) }\end{array}$ & $\begin{array}{c}\text { CHLORO- } \\
\text { DI- } \\
\text { BROMO- } \\
\text { METHANE } \\
\text { TOTAL } \\
\text { (UG/L) }\end{array}$ & $\begin{array}{l}\text { CHLORO- } \\
\text { ETHANE } \\
\text { TOTAL } \\
\text { (UG/L) }\end{array}$ & $\begin{array}{l}\text { CHLORO- } \\
\text { FORM } \\
\text { TOTAL } \\
\text { (UG/L) }\end{array}$ & $\begin{array}{l}\text { CIS-1, } 2 \\
\text {-DI- } \\
\text { CHLORO- } \\
\text { ETHENE } \\
\text { WATER } \\
\text { TOTAL } \\
\text { (UG/L) }\end{array}$ & $\begin{array}{c}\text { CIS } \\
1,3-D I- \\
\text { CHLORO- } \\
\text { PROPENE } \\
\text { TOTAL } \\
\text { (UG/L) }\end{array}$ \\
\hline $\begin{array}{l}344800101324901 \\
345826100580501 \\
351656101161101 \\
351914101204401 \\
352035100293301\end{array}$ & $\begin{array}{l}<.10 \\
<.10 \\
<.10 \\
<.10 \\
<.10\end{array}$ & $\begin{array}{l}<.04 \\
<.04 \\
<.04 \\
<.04 \\
<.04\end{array}$ & $\begin{array}{l}<.1 \\
<.1 \\
<.1 \\
<.1 \\
<.1\end{array}$ & $\begin{array}{l}<.10 \\
<.10 \\
<.10 \\
<.10 \\
<.10\end{array}$ & $\begin{array}{l}<.37 \\
<.37 \\
<.37 \\
<.37 \\
<.37\end{array}$ & $\begin{array}{l}<.09 \\
<.09 \\
<.09 \\
<.09 \\
<.09\end{array}$ & $\begin{array}{l}<.03 \\
<.03 \\
<.03 \\
<.03 \\
<.03\end{array}$ & $\begin{array}{l}<.2 \\
<.2 \\
<.2 \\
<.2 \\
<.2\end{array}$ & $\begin{array}{l}<.1 \\
<.1 \\
<.1 \\
<.1 \\
<.1\end{array}$ & $\begin{array}{l}<.05 \\
<.05 \\
<.05 \\
<.05 \\
<.05\end{array}$ & $\begin{array}{l}<.04 \\
<.04 \\
<.04 \\
<.04 \\
<.04\end{array}$ & $\begin{array}{l}<.09 \\
<.09 \\
<.09 \\
<.09 \\
<.09\end{array}$ \\
\hline $\begin{array}{l}352249100425401 \\
352513101372101 \\
352909101084001 \\
353110100550401 \\
353941102350201\end{array}$ & $\begin{array}{l}<.10 \\
<.10 \\
<.10 \\
<.10 \\
<.10\end{array}$ & $\begin{array}{l}<.04 \\
<.04 \\
<.04 \\
<.04 \\
<.04\end{array}$ & $\begin{array}{l}<.1 \\
<.1 \\
<.1 \\
<.1 \\
<.1\end{array}$ & $\begin{array}{l}<.10 \\
<.10 \\
<.10 \\
<.10 \\
<.10\end{array}$ & $\begin{array}{l}<.37 \\
<.37 \\
<.37 \\
<.37 \\
<.37\end{array}$ & $\begin{array}{l}<.09 \\
<.09 \\
<.09 \\
<.09 \\
<.09\end{array}$ & $\begin{array}{l}<.03 \\
<.03 \\
<.03 \\
<.03 \\
<.03\end{array}$ & $\begin{array}{l}<.2 \\
<.2 \\
<.2 \\
<.2 \\
<.2\end{array}$ & $\begin{array}{l}<.1 \\
<.1 \\
<.1 \\
<.1 \\
<.1\end{array}$ & $\begin{array}{l}<.05 \\
<.05 \\
<.05 \\
<.05 \\
<.05\end{array}$ & $\begin{array}{l}<.04 \\
<.04 \\
<.04 \\
<.04 \\
<.04\end{array}$ & $\begin{array}{l}<.09 \\
<.09 \\
<.09 \\
<.09 \\
<.09\end{array}$ \\
\hline $\begin{array}{l}354248100501501 \\
354331102183601 \\
354348102543601 \\
354656099480301 \\
354728102295901\end{array}$ & $\begin{array}{l}<.10 \\
<.10 \\
<.10 \\
<.10 \\
<.10\end{array}$ & $\begin{array}{l}<.04 \\
<.04 \\
<.04 \\
<.04 \\
<.04\end{array}$ & $\begin{array}{l}<.1 \\
<.1 \\
<.1 \\
<.1 \\
<.1\end{array}$ & $\begin{array}{l}<.10 \\
<.10 \\
<.10 \\
<.10 \\
<.10\end{array}$ & $\begin{array}{l}<.37 \\
<.37 \\
<.37 \\
<.37 \\
<.37\end{array}$ & $\begin{array}{l}<.09 \\
<.09 \\
<.09 \\
<.09 \\
<.09\end{array}$ & $\begin{array}{l}<.03 \\
<.03 \\
<.03 \\
<.03 \\
<.03\end{array}$ & $\begin{array}{l}<.2 \\
<.2 \\
<.2 \\
<.2 \\
<.2\end{array}$ & $\begin{array}{l}<.1 \\
<.1 \\
<.1 \\
<.1 \\
<.1\end{array}$ & $\begin{array}{l}<.05 \\
<.05 \\
<.05 \\
<.05 \\
<.05\end{array}$ & $\begin{array}{l}<.04 \\
<.04 \\
<.04 \\
<.04 \\
<.04\end{array}$ & $\begin{array}{l}<.09 \\
<.09 \\
<.09 \\
<.09 \\
<.09\end{array}$ \\
\hline $\begin{array}{l}354918102020901 \\
355701100313001 \\
355852101274101 \\
355916103215201 \\
360703102361901\end{array}$ & $\begin{array}{l}<.10 \\
<.10 \\
<.10 \\
<.10 \\
<.10\end{array}$ & $\begin{array}{l}<.04 \\
<.04 \\
<.04 \\
<.04 \\
<.04\end{array}$ & $\begin{array}{l}<.1 \\
<.1 \\
<.1 \\
<.1 \\
<.1\end{array}$ & $\begin{array}{l}<.10 \\
<.10 \\
<.10 \\
<.10 \\
<.10\end{array}$ & $\begin{array}{l}<.37 \\
<.37 \\
<.37 \\
<.37 \\
<.37\end{array}$ & $\begin{array}{l}<.09 \\
<.09 \\
<.09 \\
<.09 \\
<.09\end{array}$ & $\begin{array}{l}<.03 \\
<.03 \\
<.03 \\
<.03 \\
<.03\end{array}$ & $\begin{array}{l}<.2 \\
<.2 \\
<.2 \\
<.2 \\
<.2\end{array}$ & $\begin{array}{l}<.1 \\
<.1 \\
<.1 \\
<.1 \\
<.1\end{array}$ & $\begin{array}{l}<.05 \\
<.05 \\
<.05 \\
<.05 \\
<.05\end{array}$ & $\begin{array}{l}<.04 \\
<.04 \\
<.04 \\
<.04 \\
<.04\end{array}$ & $\begin{array}{l}<.09 \\
<.09 \\
<.09 \\
<.09 \\
<.09\end{array}$ \\
\hline $\begin{array}{l}360838102560301 \\
360944100162101 \\
361014100221001 \\
361049100564901 \\
361054101393601\end{array}$ & $\begin{array}{l}<.10 \\
<.10 \\
<.10 \\
<.10 \\
<.10\end{array}$ & $\begin{array}{l}<.04 \\
<.04 \\
<.04 \\
<.04 \\
<.04\end{array}$ & $\begin{array}{l}<.1 \\
<.1 \\
<.1 \\
<.1 \\
<.1\end{array}$ & $\begin{array}{l}<.10 \\
<.10 \\
<.10 \\
<.10 \\
<.10\end{array}$ & $\begin{array}{l}<.37 \\
<.37 \\
<.37 \\
<.37 \\
<.37\end{array}$ & $\begin{array}{l}<.09 \\
<.09 \\
<.09 \\
<.09 \\
<.09\end{array}$ & $\begin{array}{l}<.03 \\
<.03 \\
<.03 \\
<.03 \\
<.03\end{array}$ & $\begin{array}{l}<.2 \\
<.2 \\
<.2 \\
<.2 \\
<.2\end{array}$ & $\begin{array}{l}<.1 \\
<.1 \\
<.1 \\
<.1 \\
<.1\end{array}$ & $\begin{array}{l}<.05 \\
<.05 \\
<.05 \\
<.05 \\
<.05\end{array}$ & $\begin{array}{l}<.04 \\
<.04 \\
<.04 \\
<.04 \\
<.04\end{array}$ & $\begin{array}{l}<.09 \\
<.09 \\
<.09 \\
<.09 \\
<.09\end{array}$ \\
\hline $\begin{array}{l}361114099420501 \\
361517102065301 \\
362115101173901 \\
362134102035101 \\
362615100435801\end{array}$ & $\begin{array}{l}<.10 \\
<.10 \\
<.10 \\
<.10 \\
<.10\end{array}$ & $\begin{array}{l}<.04 \\
<.04 \\
<.04 \\
<.04 \\
<.04\end{array}$ & $\begin{array}{l}<.1 \\
<.1 \\
<.1 \\
<.1 \\
<.1\end{array}$ & $\begin{array}{l}<.10 \\
<.10 \\
<.10 \\
<.10 \\
<.10\end{array}$ & $\begin{array}{l}<.37 \\
<.37 \\
<.37 \\
<.37 \\
<.37\end{array}$ & $\begin{array}{l}<.09 \\
<.09 \\
<.09 \\
<.09 \\
<.09\end{array}$ & $\begin{array}{l}<.03 \\
<.03 \\
<.03 \\
<.03 \\
<.03\end{array}$ & $\begin{array}{l}<.2 \\
<.2 \\
<.2 \\
<.2 \\
<.2\end{array}$ & $\begin{array}{l}<.1 \\
<.1 \\
<.1 \\
<.1 \\
<.1\end{array}$ & $\begin{array}{l}<.05 \\
<.05 \\
<.05 \\
<.05 \\
<.05\end{array}$ & $\begin{array}{l}<.04 \\
<.04 \\
<.04 \\
<.04 \\
<.04\end{array}$ & $\begin{array}{l}<.09 \\
<.09 \\
<.09 \\
<.09 \\
<.09\end{array}$ \\
\hline $\begin{array}{l}362744102334901 \\
363057101384701 \\
363104100035501 \\
363154099310401 \\
363157102565601\end{array}$ & $\begin{array}{l}<.10 \\
<.10 \\
<.10 \\
<.10 \\
<.10\end{array}$ & $\begin{array}{l}<.04 \\
<.04 \\
<.04 \\
<.04 \\
<.04\end{array}$ & $\begin{array}{l}<.1 \\
<.1 \\
<.1 \\
<.1 \\
<.1\end{array}$ & $\begin{array}{l}<.10 \\
<.10 \\
<.10 \\
<.10 \\
<.10\end{array}$ & $\begin{array}{l}<.37 \\
<.37 \\
<.37 \\
<.37 \\
<.37\end{array}$ & $\begin{array}{l}<.09 \\
<.09 \\
<.09 \\
<.09 \\
<.09\end{array}$ & $\begin{array}{l}<.03 \\
<.03 \\
<.03 \\
<.03 \\
<.03\end{array}$ & $\begin{array}{l}<.2 \\
<.2 \\
<.2 \\
<.2 \\
<.2\end{array}$ & $\begin{array}{l}<.1 \\
<.1 \\
<.1 \\
<.1 \\
<.1\end{array}$ & $\begin{array}{l}\text { E.05 } \\
<.05 \\
<.05 \\
<.05 \\
<.05\end{array}$ & $\begin{array}{l}<.04 \\
<.04 \\
<.04 \\
<.04 \\
<.04\end{array}$ & $\begin{array}{l}<.09 \\
<.09 \\
<.09 \\
<.09 \\
<.09\end{array}$ \\
\hline $\begin{array}{l}363239100301801 \\
363427102440401 \\
364219101394101 \\
364411102321201 \\
365223102113001\end{array}$ & $\begin{array}{l}<.10 \\
<.10 \\
<.10 \\
<.10 \\
<.10\end{array}$ & $\begin{array}{l}<.04 \\
<.04 \\
<.04 \\
<.04 \\
<.04\end{array}$ & $\begin{array}{l}<.1 \\
<.1 \\
<.1 \\
<.1 \\
<.1\end{array}$ & $\begin{array}{l}<.10 \\
<.10 \\
<.10 \\
<.10 \\
<.10\end{array}$ & $\begin{array}{l}<.37 \\
<.37 \\
<.37 \\
<.37 \\
<.37\end{array}$ & $\begin{array}{l}<.09 \\
<.09 \\
<.09 \\
<.09 \\
<.09\end{array}$ & $\begin{array}{l}<.03 \\
<.03 \\
<.03 \\
<.03 \\
<.03\end{array}$ & $\begin{array}{l}<.2 \\
<.2 \\
<.2 \\
<.2 \\
<.2\end{array}$ & $\begin{array}{l}<.1 \\
<.1 \\
<.1 \\
<.1 \\
<.1\end{array}$ & $\begin{array}{l}<.05 \\
<.05 \\
<.05 \\
<.05 \\
<.05\end{array}$ & $\begin{array}{l}<.04 \\
<.04 \\
<.04 \\
<.04 \\
<.04\end{array}$ & $\begin{array}{l}<.09 \\
<.09 \\
<.09 \\
<.09 \\
<.09\end{array}$ \\
\hline $\begin{array}{l}365422101083701 \\
365445100381901 \\
365821101375301 \\
365934101573001 \\
370358100510301\end{array}$ & $\begin{array}{l}<.10 \\
<.10 \\
<.10 \\
<.10 \\
<.10\end{array}$ & $\begin{array}{l}<.04 \\
<.04 \\
<.04 \\
<.04 \\
<.04\end{array}$ & $\begin{array}{l}<.1 \\
<.1 \\
<.1 \\
<.1 \\
<.1\end{array}$ & $\begin{array}{l}<.10 \\
<.10 \\
<.10 \\
<.10 \\
<.10\end{array}$ & $\begin{array}{l}<.37 \\
<.37 \\
<.37 \\
<.37 \\
<.37\end{array}$ & $\begin{array}{l}<.09 \\
<.09 \\
<.09 \\
<.09 \\
<.09\end{array}$ & $\begin{array}{l}<.03 \\
<.03 \\
<.03 \\
<.03 \\
<.03\end{array}$ & $\begin{array}{l}<.2 \\
<.2 \\
<.2 \\
<.2 \\
<.2\end{array}$ & $\begin{array}{l}<.1 \\
<.1 \\
<.1 \\
<.1 \\
<.1\end{array}$ & $\begin{array}{l}<.05 \\
<.05 \\
<.05 \\
<.05 \\
<.05\end{array}$ & $\begin{array}{l}<.04 \\
<.04 \\
<.04 \\
<.04 \\
<.04\end{array}$ & $\begin{array}{l}<.09 \\
<.09 \\
<.09 \\
<.09 \\
<.09\end{array}$ \\
\hline $\begin{array}{l}370458101514401 \\
370724100281601 \\
371738101220301 \\
372534100443501 \\
372649101344701\end{array}$ & $\begin{array}{l}<.10 \\
<.10 \\
<.10 \\
<.10 \\
<.10\end{array}$ & $\begin{array}{l}<.04 \\
<.04 \\
<.04 \\
<.04 \\
<.04\end{array}$ & $\begin{array}{l}<.1 \\
<.1 \\
<.1 \\
<.1 \\
<.1\end{array}$ & $\begin{array}{l}<.10 \\
<.10 \\
<.10 \\
<.10 \\
<.10\end{array}$ & $\begin{array}{l}<.37 \\
<.37 \\
<.37 \\
<.37 \\
<.37\end{array}$ & $\begin{array}{l}<.09 \\
<.09 \\
<.09 \\
<.09 \\
<.09\end{array}$ & $\begin{array}{l}<.03 \\
<.03 \\
<.03 \\
<.03 \\
<.03\end{array}$ & $\begin{array}{l}<.2 \\
<.2 \\
<.2 \\
<.2 \\
<.2\end{array}$ & $\begin{array}{l}<.1 \\
<.1 \\
<.1 \\
<.1 \\
<.1\end{array}$ & $\begin{array}{l}<.05 \\
<.05 \\
<.05 \\
<.05 \\
<.05\end{array}$ & $\begin{array}{l}<.04 \\
<.04 \\
<.04 \\
<.04 \\
<.04\end{array}$ & $\begin{array}{l}<.09 \\
<.09 \\
<.09 \\
<.09 \\
<.09\end{array}$ \\
\hline $\begin{array}{l}372956099512201 \\
373229101193201 \\
373345101070801 \\
373507102162001 \\
373527100312701\end{array}$ & $\begin{array}{l}<.10 \\
<.10 \\
<.10 \\
<.10 \\
<.10\end{array}$ & $\begin{array}{l}<.04 \\
<.04 \\
<.04 \\
<.04 \\
<.04\end{array}$ & $\begin{array}{l}<.1 \\
<.1 \\
<.1 \\
<.1 \\
<.1\end{array}$ & $\begin{array}{l}<.10 \\
<.10 \\
<.10 \\
<.10 \\
<.10\end{array}$ & $\begin{array}{l}<.37 \\
<.37 \\
<.37 \\
<.37 \\
<.37\end{array}$ & $\begin{array}{l}<.09 \\
<.09 \\
<.09 \\
<.09 \\
<.09\end{array}$ & $\begin{array}{l}<.03 \\
<.03 \\
<.03 \\
<.03 \\
<.03\end{array}$ & $\begin{array}{l}<.2 \\
<.2 \\
<.2 \\
<.2 \\
<.2\end{array}$ & $\begin{array}{l}<.1 \\
<.1 \\
<.1 \\
<.1 \\
<.1\end{array}$ & $\begin{array}{l}<.05 \\
<.05 \\
<.05 \\
<.05 \\
<.05\end{array}$ & $\begin{array}{l}<.04 \\
<.04 \\
<.04 \\
<.04 \\
<.04\end{array}$ & $\begin{array}{l}<.09 \\
<.09 \\
<.09 \\
<.09 \\
<.09\end{array}$ \\
\hline $\begin{array}{l}373559102314901 \\
373732099291201 \\
374535102110301 \\
374650100181901 \\
375129100532301\end{array}$ & $\begin{array}{l}<.10 \\
<.10 \\
<.10 \\
<.10 \\
<.10\end{array}$ & $\begin{array}{l}<.04 \\
<.04 \\
<.04 \\
<.04 \\
<.04\end{array}$ & $\begin{array}{l}<.1 \\
<.1 \\
<.1 \\
<.1 \\
<.1\end{array}$ & $\begin{array}{l}<.10 \\
<.10 \\
<.10 \\
<.10 \\
<.10\end{array}$ & $\begin{array}{l}<.37 \\
<.37 \\
<.37 \\
<.37 \\
<.37\end{array}$ & $\begin{array}{l}<.09 \\
<.09 \\
<.09 \\
<.09 \\
<.09\end{array}$ & $\begin{array}{l}<.03 \\
<.03 \\
<.03 \\
<.03 \\
<.03\end{array}$ & $\begin{array}{l}<.2 \\
<.2 \\
<.2 \\
<.2 \\
<.2\end{array}$ & $\begin{array}{l}<.1 \\
<.1 \\
<.1 \\
<.1 \\
<.1\end{array}$ & $\begin{array}{l}<.05 \\
<.05 \\
<.05 \\
<.05 \\
<.05\end{array}$ & $\begin{array}{l}<.04 \\
<.04 \\
<.04 \\
<.04 \\
<.04\end{array}$ & $\begin{array}{l}<.09 \\
<.09 \\
<.09 \\
<.09 \\
<.09\end{array}$ \\
\hline $\begin{array}{l}375447099245001 \\
375828101111801 \\
380331100352801 \\
382947100443201 \\
383008101315601\end{array}$ & $\begin{array}{l}<.10 \\
<.10 \\
<.10 \\
<.10 \\
<.10\end{array}$ & $\begin{array}{l}<.04 \\
<.04 \\
<.04 \\
<.04 \\
<.04\end{array}$ & $\begin{array}{l}<.1 \\
<.1 \\
<.1 \\
<.1 \\
<.1\end{array}$ & $\begin{array}{l}<.10 \\
<.10 \\
<.10 \\
<.10 \\
<.10\end{array}$ & $\begin{array}{l}<.37 \\
<.37 \\
<.37 \\
<.37 \\
<.37\end{array}$ & $\begin{array}{l}<.09 \\
<.09 \\
<.09 \\
<.09 \\
<.09\end{array}$ & $\begin{array}{l}<.03 \\
<.03 \\
<.03 \\
<.03 \\
<.03\end{array}$ & $\begin{array}{l}<.2 \\
<.2 \\
<.2 \\
<.2 \\
<.2\end{array}$ & $\begin{array}{l}<.1 \\
<.1 \\
<.1 \\
<.1 \\
<.1\end{array}$ & $\begin{array}{l}<.05 \\
<.05 \\
<.05 \\
<.05 \\
<.05\end{array}$ & $\begin{array}{l}<.04 \\
<.04 \\
<.04 \\
<.04 \\
<.04\end{array}$ & $\begin{array}{l}<.09 \\
<.09 \\
<.09 \\
<.09 \\
<.09\end{array}$ \\
\hline $\begin{array}{l}383758101195801 \\
383919101040101 \\
385210100164501 \\
385904099522201 \\
390622101003201\end{array}$ & $\begin{array}{l}<.10 \\
<.10 \\
<.10 \\
<.10 \\
<.10\end{array}$ & $\begin{array}{l}<.04 \\
<.04 \\
<.04 \\
<.04 \\
<.04\end{array}$ & $\begin{array}{l}<.1 \\
<.1 \\
<.1 \\
<.1 \\
<.1\end{array}$ & $\begin{array}{l}<.10 \\
<.10 \\
<.10 \\
<.10 \\
<.10\end{array}$ & $\begin{array}{l}<.37 \\
<.37 \\
<.37 \\
<.37 \\
<.37\end{array}$ & $\begin{array}{l}<.09 \\
<.09 \\
<.09 \\
<.09 \\
<.09\end{array}$ & $\begin{array}{l}<.03 \\
<.03 \\
<.03 \\
<.03 \\
<.03\end{array}$ & $\begin{array}{l}<.2 \\
<.2 \\
<.2 \\
<.2 \\
<.2\end{array}$ & $\begin{array}{l}<.1 \\
<.1 \\
<.1 \\
<.1 \\
<.1\end{array}$ & $\begin{array}{l}<.05 \\
<.05 \\
<.05 \\
<.05 \\
<.05\end{array}$ & $\begin{array}{l}<.04 \\
<.04 \\
<.04 \\
<.04 \\
<.04\end{array}$ & $\begin{array}{l}<.09 \\
<.09 \\
<.09 \\
<.09 \\
<.09\end{array}$ \\
\hline
\end{tabular}




\begin{tabular}{|c|c|c|c|c|c|c|c|c|c|c|c|c|}
\hline STATION NUMBER & $\begin{array}{l}\text { DIBROMO } \\
\text { CHLORO- } \\
\text { PROPANE } \\
\text { WATER } \\
\text { WHOLE } \\
\text { TOT.REC } \\
\text { (UG/L) }\end{array}$ & $\begin{array}{c}\text { DI- } \\
\text { BROMO- } \\
\text { METHANE } \\
\text { WATER } \\
\text { WHOLE } \\
\text { RECOVER } \\
\text { (UG/L) }\end{array}$ & $\begin{array}{c}\text { BROMO- } \\
\text { DI- } \\
\text { CHLORO- } \\
\text { METHANE } \\
\text { TOTAL } \\
\text { (UG/L) }\end{array}$ & $\begin{array}{l}\quad \text { DI- } \\
\text { CHLORO- } \\
\text { DI- } \\
\text { FLUORO- } \\
\text { METHANE } \\
\text { TOTAL } \\
\text { (UG/L) }\end{array}$ & $\begin{array}{l}\text { DI-ISO- } \\
\text { PROPYL- } \\
\text { ETHER, } \\
\text { WATER, } \\
\text { UNFLTRD } \\
\text { RECOVER } \\
\text { (UG/L) }\end{array}$ & $\begin{array}{c}\text { ETHANE, } \\
\text { 1112- } \\
\text { TETRA- } \\
\text { CHLORO- } \\
\text { WAT UNF } \\
\text { REC } \\
\text { (UG/L) }\end{array}$ & $\begin{array}{c}\text { ETHANE, } \\
1,1,2,2 \\
\text { TETRA- } \\
\text { CHLORO- } \\
\text { WAT UNF } \\
\text { REC } \\
\text { (UG/L) }\end{array}$ & $\begin{array}{c}\text { ETHANE } \\
\text { 12DICL } \\
\text { SURROG } \\
\text { VOC } \\
\text { UNFLTRD } \\
\text { REC } \\
\text { PERCENT }\end{array}$ & $\begin{array}{c}\text { ETHANE } \\
\text { HEXA- } \\
\text { CHLORO- } \\
\text { WATER } \\
\text { UNFLTRD } \\
\text { RECOVER } \\
\text { (UG/L) }\end{array}$ & $\begin{array}{c}\text { ETHER } \\
\text { ETHYL } \\
\text { WATER } \\
\text { UNFLTRD } \\
\text { RECOVER } \\
\text { (UG/L) }\end{array}$ & $\begin{array}{l}\text { ETHER } \\
\text { TERT- } \\
\text { BUTYL } \\
\text { ETHYL } \\
\text { UNFLTRD } \\
\text { RECOVER } \\
\text { (UG/L) }\end{array}$ & $\begin{array}{l}\text { ETHER } \\
\text { TERT- } \\
\text { PENTYL } \\
\text { METHYL } \\
\text { UNELTRD } \\
\text { RECOVER } \\
\text { (UG/L) }\end{array}$ \\
\hline $\begin{array}{l}344800101324901 \\
345826100580501 \\
351656101161101 \\
351914101204401 \\
352035100293301\end{array}$ & $\begin{array}{l}<.2 \\
<.2 \\
<.2 \\
<.2 \\
<.2\end{array}$ & $\begin{array}{l}<.05 \\
<.05 \\
<.05 \\
<.05 \\
<.05\end{array}$ & $\begin{array}{l}<.05 \\
<.05 \\
<.05 \\
<.05 \\
<.05\end{array}$ & $\begin{array}{l}<.1 \\
<.1 \\
<.1 \\
<.1 \\
<.1\end{array}$ & $\begin{array}{l}<.1 \\
<.1 \\
<.1 \\
<.1 \\
<.1\end{array}$ & $\begin{array}{l}<.04 \\
<.04 \\
<.04 \\
<.04 \\
<.04\end{array}$ & $\begin{array}{l}<.13 \\
<.13 \\
<.13 \\
<.13 \\
<.13\end{array}$ & $\begin{array}{r}100 \\
99 \\
99 \\
106 \\
106\end{array}$ & $\begin{array}{l}<.4 \\
<.4 \\
<.4 \\
<.4 \\
<.4\end{array}$ & $\begin{array}{l}<.2 \\
<.2 \\
<.2 \\
<.2 \\
<.2\end{array}$ & $\begin{array}{l}<.05 \\
<.05 \\
<.05 \\
<.05 \\
<.05\end{array}$ & $\begin{array}{l}<.1 \\
<.1 \\
<.1 \\
<.1 \\
<.1\end{array}$ \\
\hline $\begin{array}{l}352249100425401 \\
352513101372101 \\
352909101084001 \\
353110100550401 \\
353941102350201\end{array}$ & $\begin{array}{l}<.2 \\
<.2 \\
<.2 \\
<.2 \\
<.2\end{array}$ & $\begin{array}{l}<.05 \\
<.05 \\
<.05 \\
<.05 \\
<.05\end{array}$ & $\begin{array}{l}<.05 \\
<.05 \\
<.05 \\
<.05 \\
<.05\end{array}$ & $\begin{array}{l}<.1 \\
<.1 \\
<.1 \\
<.1 \\
<.1\end{array}$ & $\begin{array}{l}<.1 \\
<.1 \\
<.1 \\
<.1 \\
<.1\end{array}$ & $\begin{array}{l}<.04 \\
<.04 \\
<.04 \\
<.04 \\
<.04\end{array}$ & $\begin{array}{l}<.13 \\
<.13 \\
<.13 \\
<.13 \\
<.13\end{array}$ & $\begin{array}{l}101 \\
100 \\
109 \\
103 \\
107\end{array}$ & $\begin{array}{l}<.4 \\
<.4 \\
<.4 \\
<.4 \\
<.4\end{array}$ & $\begin{array}{l}<.2 \\
<.2 \\
<.2 \\
<.2 \\
<.2\end{array}$ & $\begin{array}{l}<.05 \\
<.05 \\
<.05 \\
<.05 \\
<.05\end{array}$ & $\begin{array}{l}<.1 \\
<.1 \\
<.1 \\
<.1 \\
<.1\end{array}$ \\
\hline $\begin{array}{l}354248100501501 \\
354331102183601 \\
354348102543601 \\
354656099480301 \\
354728102295901\end{array}$ & $\begin{array}{l}<.2 \\
<.2 \\
<.2 \\
<.2 \\
<.2\end{array}$ & $\begin{array}{l}<.05 \\
<.05 \\
<.05 \\
<.05 \\
<.05\end{array}$ & $\begin{array}{l}<.05 \\
<.05 \\
<.05 \\
<.05 \\
<.05\end{array}$ & $\begin{array}{l}<.1 \\
<.1 \\
<.1 \\
<.1 \\
<.1\end{array}$ & $\begin{array}{l}<.1 \\
<.1 \\
<.1 \\
<.1 \\
<.1\end{array}$ & $\begin{array}{l}<.04 \\
<.04 \\
<.04 \\
<.04 \\
<.04\end{array}$ & $\begin{array}{l}<.13 \\
<.13 \\
<.13 \\
<.13 \\
<.13\end{array}$ & $\begin{array}{l}101 \\
109 \\
121 \\
103 \\
101\end{array}$ & $\begin{array}{l}<.4 \\
<.4 \\
<.4 \\
<.4 \\
<.4\end{array}$ & $\begin{array}{l}<.2 \\
<.2 \\
<.2 \\
<.2 \\
<.2\end{array}$ & $\begin{array}{l}<.05 \\
<.05 \\
<.05 \\
<.05 \\
<.05\end{array}$ & $\begin{array}{l}<.1 \\
<.1 \\
<.1 \\
<.1 \\
<.1\end{array}$ \\
\hline $\begin{array}{l}354918102020901 \\
355701100313001 \\
355852101274101 \\
355916103215201 \\
360703102361901\end{array}$ & $\begin{array}{l}<.2 \\
<.2 \\
<.2 \\
<.2 \\
<.2\end{array}$ & $\begin{array}{l}<.05 \\
<.05 \\
<.05 \\
<.05 \\
<.05\end{array}$ & $\begin{array}{l}<.05 \\
<.05 \\
<.05 \\
<.05 \\
<.05\end{array}$ & $\begin{array}{l}<.1 \\
<.1 \\
<.1 \\
<.1 \\
<.1\end{array}$ & $\begin{array}{l}<.1 \\
<.1 \\
<.1 \\
<.1 \\
<.1\end{array}$ & $\begin{array}{l}<.04 \\
<.04 \\
<.04 \\
<.04 \\
<.04\end{array}$ & $\begin{array}{l}<.13 \\
<.13 \\
<.13 \\
<.13 \\
<.13\end{array}$ & $\begin{array}{l}114 \\
100 \\
107 \\
101 \\
111\end{array}$ & $\begin{array}{l}<.4 \\
<.4 \\
<.4 \\
<.4 \\
<.4\end{array}$ & $\begin{array}{l}<.2 \\
<.2 \\
<.2 \\
<.2 \\
<.2\end{array}$ & $\begin{array}{l}<.05 \\
<.05 \\
<.05 \\
<.05 \\
<.05\end{array}$ & $\begin{array}{l}<.1 \\
<.1 \\
<.1 \\
<.1 \\
<.1\end{array}$ \\
\hline $\begin{array}{l}360838102560301 \\
360944100162101 \\
361014100221001 \\
361049100564901 \\
361054101393601\end{array}$ & $\begin{array}{l}<.2 \\
<.2 \\
<.2 \\
<.2 \\
<.2\end{array}$ & $\begin{array}{l}<.05 \\
<.05 \\
<.05 \\
<.05 \\
<.05\end{array}$ & $\begin{array}{l}<.05 \\
<.05 \\
<.05 \\
<.05 \\
<.05\end{array}$ & $\begin{array}{l}<.1 \\
<.1 \\
<.1 \\
<.1 \\
<.1\end{array}$ & $\begin{array}{l}<.1 \\
<.1 \\
<.1 \\
<.1 \\
<.1\end{array}$ & $\begin{array}{l}<.04 \\
<.04 \\
<.04 \\
<.04 \\
<.04\end{array}$ & $\begin{array}{l}<.13 \\
<.13 \\
<.13 \\
<.13 \\
<.13\end{array}$ & $\begin{array}{r}106 \\
95 \\
112 \\
105 \\
109\end{array}$ & $\begin{array}{l}<.4 \\
<.4 \\
<.4 \\
<.4 \\
<.4\end{array}$ & $\begin{array}{l}<.2 \\
<.2 \\
<.2 \\
<.2 \\
<.2\end{array}$ & $\begin{array}{l}<.05 \\
<.05 \\
<.05 \\
<.05 \\
<.05\end{array}$ & $\begin{array}{l}<.1 \\
<.1 \\
<.1 \\
<.1 \\
<.1\end{array}$ \\
\hline $\begin{array}{l}361114099420501 \\
361517102065301 \\
362115101173901 \\
362134102035101 \\
362615100435801\end{array}$ & $\begin{array}{l}<.2 \\
<.2 \\
<.2 \\
<.2 \\
<.2\end{array}$ & $\begin{array}{l}<.05 \\
<.05 \\
<.05 \\
<.05 \\
<.05\end{array}$ & $\begin{array}{l}<.05 \\
<.05 \\
<.05 \\
<.05 \\
<.05\end{array}$ & $\begin{array}{l}<.1 \\
<.1 \\
<.1 \\
<.1 \\
<.1\end{array}$ & $\begin{array}{l}<.1 \\
<.1 \\
<.1 \\
<.1 \\
<.1\end{array}$ & $\begin{array}{l}<.04 \\
<.04 \\
<.04 \\
<.04 \\
<.04\end{array}$ & $\begin{array}{l}<.13 \\
<.13 \\
<.13 \\
<.13 \\
<.13\end{array}$ & $\begin{array}{r}100 \\
111 \\
98 \\
110 \\
109\end{array}$ & $\begin{array}{l}<.4 \\
<.4 \\
<.4 \\
<.4 \\
<.4\end{array}$ & $\begin{array}{l}<.2 \\
<.2 \\
<.2 \\
<.2 \\
<.2\end{array}$ & $\begin{array}{l}<.05 \\
<.05 \\
<.05 \\
<.05 \\
<.05\end{array}$ & $\begin{array}{l}<.1 \\
<.1 \\
<.1 \\
<.1 \\
<.1\end{array}$ \\
\hline $\begin{array}{l}362744102334901 \\
363057101384701 \\
363104100035501 \\
363154099310401 \\
363157102565601\end{array}$ & $\begin{array}{l}<.2 \\
<.2 \\
<.2 \\
<.2 \\
<.2\end{array}$ & $\begin{array}{l}<.05 \\
<.05 \\
<.05 \\
<.05 \\
<.05\end{array}$ & $\begin{array}{l}<.05 \\
<.05 \\
<.05 \\
<.05 \\
<.05\end{array}$ & $\begin{array}{l}<.1 \\
<.1 \\
<.1 \\
<.1 \\
<.1\end{array}$ & $\begin{array}{l}<.1 \\
<.1 \\
<.1 \\
<.1 \\
<.1\end{array}$ & $\begin{array}{l}<.04 \\
<.04 \\
<.04 \\
<.04 \\
<.04\end{array}$ & $\begin{array}{l}<.13 \\
<.13 \\
<.13 \\
<.13 \\
<.13\end{array}$ & $\begin{array}{r}107 \\
99 \\
93 \\
105 \\
109\end{array}$ & $\begin{array}{l}<.4 \\
<.4 \\
<.4 \\
<.4 \\
<.4\end{array}$ & $\begin{array}{l}<.2 \\
<.2 \\
<.2 \\
<.2 \\
<.2\end{array}$ & $\begin{array}{l}<.05 \\
<.05 \\
<.05 \\
<.05 \\
<.05\end{array}$ & $\begin{array}{l}<.1 \\
<.1 \\
<.1 \\
<.1 \\
<.1\end{array}$ \\
\hline $\begin{array}{l}363239100301801 \\
363427102440401 \\
364219101394101 \\
364411102321201 \\
365223102113001\end{array}$ & $\begin{array}{l}<.2 \\
<.2 \\
<.2 \\
<.2 \\
<.2\end{array}$ & $\begin{array}{l}<.05 \\
<.05 \\
<.05 \\
<.05 \\
<.05\end{array}$ & $\begin{array}{l}<.05 \\
<.05 \\
<.05 \\
<.05 \\
<.05\end{array}$ & $\begin{array}{l}<.1 \\
<.1 \\
<.1 \\
<.1 \\
<.1\end{array}$ & $\begin{array}{l}<.1 \\
<.1 \\
<.1 \\
<.1 \\
<.1\end{array}$ & $\begin{array}{l}<.04 \\
<.04 \\
<.04 \\
<.04 \\
<.04\end{array}$ & $\begin{array}{l}<.13 \\
<.13 \\
<.13 \\
<.13 \\
<.13\end{array}$ & $\begin{array}{l}110 \\
105 \\
100 \\
105 \\
107\end{array}$ & $\begin{array}{l}<.4 \\
<.4 \\
<.4 \\
<.4 \\
<.4\end{array}$ & $\begin{array}{l}<.2 \\
<.2 \\
<.2 \\
<.2 \\
<.2\end{array}$ & $\begin{array}{l}<.05 \\
<.05 \\
<.05 \\
<.05 \\
<.05\end{array}$ & $\begin{array}{l}<.1 \\
<.1 \\
<.1 \\
<.1 \\
<.1\end{array}$ \\
\hline $\begin{array}{l}365422101083701 \\
365445100381901 \\
365821101375301 \\
365934101573001 \\
370358100510301\end{array}$ & $\begin{array}{l}<.2 \\
<.2 \\
<.2 \\
<.2 \\
<.2\end{array}$ & $\begin{array}{l}<.05 \\
<.05 \\
<.05 \\
<.05 \\
<.05\end{array}$ & $\begin{array}{l}<.05 \\
<.05 \\
<.05 \\
<.05 \\
<.05\end{array}$ & $\begin{array}{l}<.1 \\
<.1 \\
<.1 \\
<.1 \\
<.1\end{array}$ & $\begin{array}{l}<.1 \\
<.1 \\
<.1 \\
<.1 \\
<.1\end{array}$ & $\begin{array}{l}<.04 \\
<.04 \\
<.04 \\
<.04 \\
<.04\end{array}$ & $\begin{array}{l}<.13 \\
<.13 \\
<.13 \\
<.13 \\
<.13\end{array}$ & $\begin{array}{r}105 \\
115 \\
113 \\
95 \\
97\end{array}$ & $\begin{array}{l}<.4 \\
<.4 \\
<.4 \\
<.4 \\
<.4\end{array}$ & $\begin{array}{l}<.2 \\
<.2 \\
<.2 \\
<.2 \\
<.2\end{array}$ & $\begin{array}{l}<.05 \\
<.05 \\
<.05 \\
<.05 \\
<.05\end{array}$ & $\begin{array}{l}<.1 \\
<.1 \\
<.1 \\
<.1 \\
<.1\end{array}$ \\
\hline $\begin{array}{l}370458101514401 \\
370724100281601 \\
371738101220301 \\
372534100443501 \\
372649101344701\end{array}$ & $\begin{array}{l}<.2 \\
<.2 \\
<.2 \\
<.2 \\
<.2\end{array}$ & $\begin{array}{l}<.05 \\
<.05 \\
<.05 \\
<.05 \\
<.05\end{array}$ & $\begin{array}{l}<.05 \\
<.05 \\
<.05 \\
<.05 \\
<.05\end{array}$ & $\begin{array}{l}<.1 \\
<.1 \\
<.1 \\
<.1 \\
<.1\end{array}$ & $\begin{array}{l}<.1 \\
<.1 \\
<.1 \\
<.1 \\
<.1\end{array}$ & $\begin{array}{l}<.04 \\
<.04 \\
<.04 \\
<.04 \\
<.04\end{array}$ & $\begin{array}{l}<.13 \\
<.13 \\
<.13 \\
<.13 \\
<.13\end{array}$ & $\begin{array}{r}107 \\
107 \\
98 \\
109 \\
98\end{array}$ & $\begin{array}{l}<.4 \\
<.4 \\
<.4 \\
<.4 \\
<.4\end{array}$ & $\begin{array}{l}<.2 \\
<.2 \\
<.2 \\
<.2 \\
<.2\end{array}$ & $\begin{array}{l}<.05 \\
<.05 \\
<.05 \\
<.05 \\
<.05\end{array}$ & $\begin{array}{l}<.1 \\
<.1 \\
<.1 \\
<.1 \\
<.1\end{array}$ \\
\hline $\begin{array}{l}372956099512201 \\
373229101193201 \\
373345101070801 \\
373507102162001 \\
373527100312701\end{array}$ & $\begin{array}{l}<.2 \\
<.2 \\
<.2 \\
<.2 \\
<.2\end{array}$ & $\begin{array}{l}<.05 \\
<.05 \\
<.05 \\
<.05 \\
<.05\end{array}$ & $\begin{array}{l}<.05 \\
<.05 \\
<.05 \\
<.05 \\
<.05\end{array}$ & $\begin{array}{l}<.1 \\
<.1 \\
<.1 \\
<.1 \\
<.1\end{array}$ & $\begin{array}{l}<.1 \\
<.1 \\
<.1 \\
<.1 \\
<.1\end{array}$ & $\begin{array}{l}<.04 \\
<.04 \\
<.04 \\
<.04 \\
<.04\end{array}$ & $\begin{array}{l}<.13 \\
<.13 \\
<.13 \\
<.13 \\
<.13\end{array}$ & $\begin{array}{r}105 \\
108 \\
110 \\
111 \\
95\end{array}$ & $\begin{array}{l}<.4 \\
<.4 \\
<.4 \\
<.4 \\
<.4\end{array}$ & $\begin{array}{l}<.2 \\
<.2 \\
<.2 \\
<.2 \\
<.2\end{array}$ & $\begin{array}{l}<.05 \\
<.05 \\
<.05 \\
<.05 \\
<.05\end{array}$ & $\begin{array}{l}<.1 \\
<.1 \\
<.1 \\
<.1 \\
<.1\end{array}$ \\
\hline $\begin{array}{l}373559102314901 \\
373732099291201 \\
374535102110301 \\
374650100181901 \\
375129100532301\end{array}$ & $\begin{array}{l}<.2 \\
<.2 \\
<.2 \\
<.2 \\
<.2\end{array}$ & $\begin{array}{l}<.05 \\
<.05 \\
<.05 \\
<.05 \\
<.05\end{array}$ & $\begin{array}{l}<.05 \\
<.05 \\
<.05 \\
<.05 \\
<.05\end{array}$ & $\begin{array}{l}<.1 \\
<.1 \\
<.1 \\
<.1 \\
<.1\end{array}$ & $\begin{array}{l}<.1 \\
<.1 \\
<.1 \\
<.1 \\
<.1\end{array}$ & $\begin{array}{l}<.04 \\
<.04 \\
<.04 \\
<.04 \\
<.04\end{array}$ & $\begin{array}{l}<.13 \\
<.13 \\
<.13 \\
<.13 \\
<.13\end{array}$ & $\begin{array}{r}113 \\
102 \\
109 \\
95 \\
110\end{array}$ & $\begin{array}{l}<.4 \\
<.4 \\
<.4 \\
<.4 \\
<.4\end{array}$ & $\begin{array}{l}<.2 \\
<.2 \\
<.2 \\
<.2 \\
<.2\end{array}$ & $\begin{array}{l}<.05 \\
<.05 \\
<.05 \\
<.05 \\
<.05\end{array}$ & $\begin{array}{l}<.1 \\
<.1 \\
<.1 \\
<.1 \\
<.1\end{array}$ \\
\hline $\begin{array}{l}375447099245001 \\
375828101111801 \\
380331100352801 \\
382947100443201 \\
383008101315601\end{array}$ & $\begin{array}{l}<.2 \\
<.2 \\
<.2 \\
<.2 \\
<.2\end{array}$ & $\begin{array}{l}<.05 \\
<.05 \\
<.05 \\
<.05 \\
<.05\end{array}$ & $\begin{array}{l}<.05 \\
<.05 \\
<.05 \\
<.05 \\
<.05\end{array}$ & $\begin{array}{l}<.1 \\
<.1 \\
<.1 \\
<.1 \\
<.1\end{array}$ & $\begin{array}{l}<.1 \\
<.1 \\
<.1 \\
<.1 \\
<.1\end{array}$ & $\begin{array}{l}<.04 \\
<.04 \\
<.04 \\
<.04 \\
<.04\end{array}$ & $\begin{array}{l}<.13 \\
<.13 \\
<.13 \\
<.13 \\
<.13\end{array}$ & $\begin{array}{l}100 \\
108 \\
109 \\
119 \\
107\end{array}$ & $\begin{array}{l}<.4 \\
<.4 \\
<.4 \\
<.4 \\
<.4\end{array}$ & $\begin{array}{l}<.2 \\
<.2 \\
<.2 \\
<.2 \\
<.2\end{array}$ & $\begin{array}{l}<.05 \\
<.05 \\
<.05 \\
<.05 \\
<.05\end{array}$ & $\begin{array}{l}<.1 \\
<.1 \\
<.1 \\
<.1 \\
<.1\end{array}$ \\
\hline $\begin{array}{l}383758101195801 \\
383919101040101 \\
385210100164501 \\
385904099522201 \\
390622101003201\end{array}$ & $\begin{array}{l}<.2 \\
<.2 \\
<.2 \\
<.2 \\
<.2\end{array}$ & $\begin{array}{l}<.05 \\
<.05 \\
<.05 \\
<.05 \\
<.05\end{array}$ & $\begin{array}{l}<.05 \\
<.05 \\
<.05 \\
<.05 \\
<.05\end{array}$ & $\begin{array}{l}<.1 \\
<.1 \\
<.1 \\
<.1 \\
<.1\end{array}$ & $\begin{array}{l}<.1 \\
<.1 \\
<.1 \\
<.1 \\
<.1\end{array}$ & $\begin{array}{l}<.04 \\
<.04 \\
<.04 \\
<.04 \\
<.04\end{array}$ & $\begin{array}{l}<.13 \\
<.13 \\
<.13 \\
<.13 \\
<.13\end{array}$ & $\begin{array}{r}97 \\
113 \\
105 \\
98 \\
95\end{array}$ & $\begin{array}{l}<.4 \\
<.4 \\
<.4 \\
<.4 \\
<.4\end{array}$ & $\begin{array}{l}<.2 \\
<.2 \\
<.2 \\
<.2 \\
<.2\end{array}$ & $\begin{array}{l}<.05 \\
<.05 \\
<.05 \\
<.05 \\
<.05\end{array}$ & $\begin{array}{l}<.1 \\
<.1 \\
<.1 \\
<.1 \\
<.1\end{array}$ \\
\hline $\begin{array}{l}390830102052001 \\
390838100411701 \\
391044100051001 \\
391921101385501\end{array}$ & $\begin{array}{l}<.2 \\
<.2 \\
<.2 \\
<.2\end{array}$ & $\begin{array}{l}<.05 \\
<.05 \\
<.05 \\
<.05\end{array}$ & $\begin{array}{l}<.05 \\
<.05 \\
<.05 \\
<.05\end{array}$ & $\begin{array}{l}<.1 \\
<.1 \\
<.1 \\
\mathrm{E} .2\end{array}$ & $\begin{array}{l}<.1 \\
<.1 \\
<.1 \\
<.1\end{array}$ & $\begin{array}{l}<.04 \\
<.04 \\
<.04 \\
<.04\end{array}$ & $\begin{array}{l}<.13 \\
<.13 \\
<.13 \\
<.13\end{array}$ & $\begin{array}{l}102 \\
110 \\
102 \\
103\end{array}$ & $\begin{array}{l}<.4 \\
<.4 \\
<.4 \\
<.4\end{array}$ & $\begin{array}{l}<.2 \\
<.2 \\
<.2 \\
<.2\end{array}$ & $\begin{array}{l}<.05 \\
<.05 \\
<.05 \\
<.05\end{array}$ & $\begin{array}{l}<.1 \\
<.1 \\
<.1 \\
<.1\end{array}$ \\
\hline
\end{tabular}


Appendix 1. Water-quality data from 74 domestic water-supply wells completed in the central High Plains aquifer-Continued

\begin{tabular}{|c|c|c|c|c|c|c|c|c|c|c|c|c|}
\hline STATION NUMBER & $\begin{array}{l}\text { ETHYL- } \\
\text { BENZENE } \\
\text { TOTAL } \\
\text { (UG/L) }\end{array}$ & $\begin{array}{c}\text { FREON- } \\
113 \\
\text { WATER } \\
\text { UNFLTRD } \\
\text { REC } \\
\text { (UG/L) }\end{array}$ & $\begin{array}{c}\text { FURAN, } \\
\text { TETRA- } \\
\text { HYDRO- } \\
\text { WATER } \\
\text { UNFLTRD } \\
\text { RECOVER } \\
\text { (UG/L) }\end{array}$ & $\begin{array}{l}\text { HEXA- } \\
\text { CHLORO- } \\
\text { BUT- } \\
\text { ADIENE } \\
\text { TOTAL } \\
\text { (UG/L) }\end{array}$ & $\begin{array}{c}\text { ISO- } \\
\text { DURENE } \\
\text { WATER } \\
\text { UNFLTRD } \\
\text { RECOVER } \\
\text { (UG/L) }\end{array}$ & $\begin{array}{l}\text { METHAC- } \\
\text { RYLATE } \\
\text { ETHYL- } \\
\text { WATER } \\
\text { UNFLTRD } \\
\text { RECOVER } \\
\text { (UG/L) }\end{array}$ & $\begin{array}{l}\text { METHAC- } \\
\text { RYLATE } \\
\text { METHYL } \\
\text { WATER } \\
\text { UNFLTRD } \\
\text { RECOVER } \\
\text { (UG/L) }\end{array}$ & $\begin{array}{c}\text { METH- } \\
\text { ACRYLO- } \\
\text { NITRILE } \\
\text { WATER } \\
\text { UNFLTRD } \\
\text { RECOVER } \\
\text { (UG/L) }\end{array}$ & $\begin{array}{l}\text { METHANE } \\
\text { BROMO } \\
\text { CHLORO- } \\
\text { WAT } \\
\text { UNFLTRD } \\
\text { REC } \\
\text { (UG/L) }\end{array}$ & $\begin{array}{l}\text { METHYL } \\
\text { ACRY- } \\
\text { LATE } \\
\text { WATER } \\
\text { UNFLTRD } \\
\text { RECOVER } \\
\text { (UG/L) }\end{array}$ & $\begin{array}{l}\text { METHYL } \\
\text { IODIDE } \\
\text { WATER } \\
\text { UNFLTRD } \\
\text { RECOVER } \\
\text { (UG/L) }\end{array}$ & $\begin{array}{c}\text { METHYL } \\
\text { TERT- } \\
\text { BUTYL } \\
\text { ETHER } \\
\text { WAT UNF } \\
\text { REC } \\
\text { (UG/L) }\end{array}$ \\
\hline $\begin{array}{l}344800101324901 \\
345826100580501 \\
351656101161101 \\
351914101204401 \\
352035100293301\end{array}$ & $\begin{array}{l}<.03 \\
<.03 \\
<.03 \\
<.03 \\
<.03\end{array}$ & $\begin{array}{l}<.03 \\
<.03 \\
<.03 \\
<.03 \\
<.03\end{array}$ & $\begin{array}{l}<9 \\
<9 \\
<9 \\
<9 \\
<9\end{array}$ & $\begin{array}{l}<.1 \\
<.1 \\
<.1 \\
<.1 \\
<.1\end{array}$ & $\begin{array}{l}<.2 \\
<.2 \\
<.2 \\
<.2 \\
<.2\end{array}$ & $\begin{array}{l}<.3 \\
<.3 \\
<.3 \\
<.3 \\
<.3\end{array}$ & $\begin{array}{l}<.3 \\
<.3 \\
<.3 \\
<.3 \\
<.3\end{array}$ & $\begin{array}{l}<.6 \\
<.6 \\
<.6 \\
<.6 \\
<.6\end{array}$ & $\begin{array}{l}<.04 \\
<.04 \\
<.04 \\
<.04 \\
<.04\end{array}$ & $\begin{array}{l}<1 \\
<1 \\
<1 \\
<1 \\
<1\end{array}$ & $\begin{array}{l}<.2 \\
<.2 \\
<.2 \\
<.2 \\
<.2\end{array}$ & $\begin{array}{l}<.2 \\
<.2 \\
<.2 \\
<.2 \\
<.2\end{array}$ \\
\hline $\begin{array}{l}352249100425401 \\
352513101372101 \\
352909101084001 \\
353110100550401 \\
353941102350201\end{array}$ & $\begin{array}{l}<.03 \\
<.03 \\
<.03 \\
<.03 \\
<.03\end{array}$ & $\begin{array}{l}<.03 \\
<.03 \\
<.03 \\
<.03 \\
<.03\end{array}$ & $\begin{array}{l}<9 \\
<9 \\
<9 \\
<9 \\
<9\end{array}$ & $\begin{array}{l}<.1 \\
<.1 \\
<.1 \\
<.1 \\
<.1\end{array}$ & $\begin{array}{l}<.2 \\
<.2 \\
<.2 \\
<.2 \\
<.2\end{array}$ & $\begin{array}{l}<.3 \\
<.3 \\
<.3 \\
<.3 \\
<.3\end{array}$ & $\begin{array}{l}<.3 \\
<.3 \\
<.3 \\
<.3 \\
<.3\end{array}$ & $\begin{array}{l}<.6 \\
<.6 \\
<.6 \\
<.6 \\
<.6\end{array}$ & $\begin{array}{l}<.04 \\
<.04 \\
<.04 \\
<.04 \\
<.04\end{array}$ & $\begin{array}{l}<1 \\
<1 \\
<1 \\
<1 \\
<1\end{array}$ & $\begin{array}{l}<.2 \\
<.2 \\
<.2 \\
<.2 \\
<.2\end{array}$ & $\begin{array}{l}<.2 \\
<.2 \\
<.2 \\
<.2 \\
<.2\end{array}$ \\
\hline $\begin{array}{l}354248100501501 \\
354331102183601 \\
354348102543601 \\
354656099480301 \\
354728102295901\end{array}$ & $\begin{array}{l}<.03 \\
<.03 \\
<.03 \\
<.03 \\
<.03\end{array}$ & $\begin{array}{l}<.03 \\
<.03 \\
<.03 \\
<.03 \\
<.03\end{array}$ & $\begin{array}{l}<9 \\
<9 \\
<9 \\
<9 \\
<9\end{array}$ & $\begin{array}{l}<.1 \\
<.1 \\
<.1 \\
<.1 \\
<.1\end{array}$ & $\begin{array}{l}<.2 \\
<.2 \\
<.2 \\
<.2 \\
<.2\end{array}$ & $\begin{array}{l}<.3 \\
<.3 \\
<.3 \\
<.3 \\
<.3\end{array}$ & $\begin{array}{l}<.3 \\
<.3 \\
<.3 \\
<.3 \\
<.3\end{array}$ & $\begin{array}{l}<.6 \\
<.6 \\
<.6 \\
<.6 \\
<.6\end{array}$ & $\begin{array}{l}<.04 \\
<.04 \\
<.04 \\
<.04 \\
<.04\end{array}$ & $\begin{array}{l}<1 \\
<1 \\
<1 \\
<1 \\
<1\end{array}$ & $\begin{array}{l}<.2 \\
<.2 \\
<.2 \\
<.2 \\
<.2\end{array}$ & $\begin{array}{l}<.2 \\
<.2 \\
<.2 \\
<.2 \\
<.2\end{array}$ \\
\hline $\begin{array}{l}354918102020901 \\
355701100313001 \\
355852101274101 \\
355916103215201 \\
360703102361901\end{array}$ & $\begin{array}{l}<.03 \\
<.03 \\
<.03 \\
<.03 \\
<.03\end{array}$ & $\begin{array}{l}<.03 \\
<.03 \\
<.03 \\
<.03 \\
<.03\end{array}$ & $\begin{array}{l}<9 \\
<9 \\
<9 \\
<9 \\
<9\end{array}$ & $\begin{array}{l}<.1 \\
<.1 \\
<.1 \\
<.1 \\
<.1\end{array}$ & $\begin{array}{l}<.2 \\
<.2 \\
<.2 \\
<.2 \\
<.2\end{array}$ & $\begin{array}{l}<.3 \\
<.3 \\
<.3 \\
<.3 \\
<.3\end{array}$ & $\begin{array}{l}<.3 \\
<.3 \\
<.3 \\
<.3 \\
<.3\end{array}$ & $\begin{array}{l}<.6 \\
<.6 \\
<.6 \\
<.6 \\
<.6\end{array}$ & $\begin{array}{l}<.04 \\
<.04 \\
<.04 \\
<.04 \\
<.04\end{array}$ & $\begin{array}{l}<1 \\
<1 \\
<1 \\
<1 \\
<1\end{array}$ & $\begin{array}{l}<.2 \\
<.2 \\
<.2 \\
<.2 \\
<.2\end{array}$ & $\begin{array}{l}<.2 \\
<.2 \\
<.2 \\
<.2 \\
<.2\end{array}$ \\
\hline $\begin{array}{l}360838102560301 \\
360944100162101 \\
361014100221001 \\
361049100564901 \\
361054101393601\end{array}$ & $\begin{array}{l}<.03 \\
<.03 \\
<.03 \\
<.03 \\
<.03\end{array}$ & $\begin{array}{l}<.03 \\
<.03 \\
<.03 \\
<.03 \\
<.03\end{array}$ & $\begin{array}{l}<9 \\
<9 \\
<9 \\
<9 \\
<9\end{array}$ & $\begin{array}{l}<.1 \\
<.1 \\
<.1 \\
<.1 \\
<.1\end{array}$ & $\begin{array}{l}<.2 \\
<.2 \\
<.2 \\
<.2 \\
<.2\end{array}$ & $\begin{array}{l}<.3 \\
<.3 \\
<.3 \\
<.3 \\
<.3\end{array}$ & $\begin{array}{l}<.3 \\
<.3 \\
<.3 \\
<.3 \\
<.3\end{array}$ & $\begin{array}{l}<.6 \\
<.6 \\
<.6 \\
<.6 \\
<.6\end{array}$ & $\begin{array}{l}<.04 \\
<.04 \\
<.04 \\
<.04 \\
<.04\end{array}$ & $\begin{array}{l}<1 \\
<1 \\
<1 \\
<1 \\
<1\end{array}$ & $\begin{array}{l}<.2 \\
<.2 \\
<.2 \\
<.2 \\
<.2\end{array}$ & $\begin{array}{l}<.2 \\
<.2 \\
<.2 \\
<.2 \\
<.2\end{array}$ \\
\hline $\begin{array}{l}361114099420501 \\
361517102065301 \\
362115101173901 \\
362134102035101 \\
362615100435801\end{array}$ & $\begin{array}{l}<.03 \\
<.03 \\
<.03 \\
<.03 \\
<.03\end{array}$ & $\begin{array}{l}<.03 \\
<.03 \\
<.03 \\
<.03 \\
<.03\end{array}$ & $\begin{array}{l}<9 \\
<9 \\
<9 \\
<9 \\
<9\end{array}$ & $\begin{array}{l}<.1 \\
<.1 \\
<.1 \\
<.1 \\
<.1\end{array}$ & $\begin{array}{l}<.2 \\
<.2 \\
<.2 \\
<.2 \\
<.2\end{array}$ & $\begin{array}{l}<.3 \\
<.3 \\
<.3 \\
<.3 \\
<.3\end{array}$ & $\begin{array}{l}<.3 \\
<.3 \\
<.3 \\
<.3 \\
<.3\end{array}$ & $\begin{array}{l}<.6 \\
<.6 \\
<.6 \\
<.6 \\
<.6\end{array}$ & $\begin{array}{l}<.04 \\
<.04 \\
<.04 \\
<.04 \\
<.04\end{array}$ & $\begin{array}{l}<1 \\
<1 \\
<1 \\
<1 \\
<1\end{array}$ & $\begin{array}{l}<.2 \\
<.2 \\
<.2 \\
<.2 \\
<.2\end{array}$ & $\begin{array}{l}<.2 \\
<.2 \\
<.2 \\
<.2 \\
<.2\end{array}$ \\
\hline $\begin{array}{l}362744102334901 \\
363057101384701 \\
363104100035501 \\
363154099310401 \\
363157102565601\end{array}$ & $\begin{array}{l}<.03 \\
<.03 \\
<.03 \\
<.03 \\
<.03\end{array}$ & $\begin{array}{l}<.03 \\
<.03 \\
<.03 \\
<.03 \\
<.03\end{array}$ & $\begin{array}{l}<9 \\
<9 \\
<9 \\
<9 \\
<9\end{array}$ & $\begin{array}{l}<.1 \\
<.1 \\
<.1 \\
<.1 \\
<.1\end{array}$ & $\begin{array}{l}<.2 \\
<.2 \\
<.2 \\
<.2 \\
<.2\end{array}$ & $\begin{array}{l}<.3 \\
<.3 \\
<.3 \\
<.3 \\
<.3\end{array}$ & $\begin{array}{l}<.3 \\
<.3 \\
<.3 \\
<.3 \\
<.3\end{array}$ & $\begin{array}{l}<.6 \\
<.6 \\
<.6 \\
<.6 \\
<.6\end{array}$ & $\begin{array}{l}<.04 \\
<.04 \\
<.04 \\
<.04 \\
<.04\end{array}$ & $\begin{array}{l}<1 \\
<1 \\
<1 \\
<1 \\
<1\end{array}$ & $\begin{array}{l}<.2 \\
<.2 \\
<.2 \\
<.2 \\
<.2\end{array}$ & $\begin{array}{l}<.2 \\
<.2 \\
<.2 \\
<.2 \\
<.2\end{array}$ \\
\hline $\begin{array}{l}363239100301801 \\
363427102440401 \\
364219101394101 \\
364411102321201 \\
365223102113001\end{array}$ & $\begin{array}{l}<.03 \\
<.03 \\
<.03 \\
<.03 \\
<.03\end{array}$ & $\begin{array}{l}<.03 \\
<.03 \\
<.03 \\
<.03 \\
<.03\end{array}$ & $\begin{array}{l}<9 \\
<9 \\
<9 \\
<9 \\
<9\end{array}$ & $\begin{array}{l}<.1 \\
<.1 \\
<.1 \\
<.1 \\
<.1\end{array}$ & $\begin{array}{l}<.2 \\
<.2 \\
<.2 \\
<.2 \\
<.2\end{array}$ & $\begin{array}{l}<.3 \\
<.3 \\
<.3 \\
<.3 \\
<.3\end{array}$ & $\begin{array}{l}<.3 \\
<.3 \\
<.3 \\
<.3 \\
<.3\end{array}$ & $\begin{array}{l}<.6 \\
<.6 \\
<.6 \\
<.6 \\
<.6\end{array}$ & $\begin{array}{l}<.04 \\
<.04 \\
<.04 \\
<.04 \\
<.04\end{array}$ & $\begin{array}{l}<1 \\
<1 \\
<1 \\
<1 \\
<1\end{array}$ & $\begin{array}{l}<.2 \\
<.2 \\
<.2 \\
<.2 \\
<.2\end{array}$ & $\begin{array}{l}<.2 \\
<.2 \\
<.2 \\
<.2 \\
<.2\end{array}$ \\
\hline $\begin{array}{l}365422101083701 \\
365445100381901 \\
365821101375301 \\
365934101573001 \\
370358100510301\end{array}$ & $\begin{array}{l}<.03 \\
<.03 \\
<.03 \\
<.03 \\
<.03\end{array}$ & $\begin{array}{l}<.03 \\
<.03 \\
<.03 \\
<.03 \\
<.03\end{array}$ & $\begin{array}{l}<9 \\
<9 \\
<9 \\
<9 \\
<9\end{array}$ & $\begin{array}{l}<.1 \\
<.1 \\
<.1 \\
<.1 \\
<.1\end{array}$ & $\begin{array}{l}<.2 \\
<.2 \\
<.2 \\
<.2 \\
<.2\end{array}$ & $\begin{array}{l}<.3 \\
<.3 \\
<.3 \\
<.3 \\
<.3\end{array}$ & $\begin{array}{l}<.3 \\
<.3 \\
<.3 \\
<.3 \\
<.3\end{array}$ & $\begin{array}{l}<.6 \\
<.6 \\
<.6 \\
<.6 \\
<.6\end{array}$ & $\begin{array}{l}<.04 \\
<.04 \\
<.04 \\
<.04 \\
<.04\end{array}$ & $\begin{array}{l}<1 \\
<1 \\
<1 \\
<1 \\
<1\end{array}$ & $\begin{array}{l}<.2 \\
<.2 \\
<.2 \\
<.2 \\
<.2\end{array}$ & $\begin{array}{l}<.2 \\
<.2 \\
<.2 \\
<.2 \\
<.2\end{array}$ \\
\hline $\begin{array}{l}370458101514401 \\
370724100281601 \\
371738101220301 \\
372534100443501 \\
372649101344701\end{array}$ & $\begin{array}{l}<.03 \\
<.03 \\
<.03 \\
<.03 \\
<.03\end{array}$ & $\begin{array}{l}<.03 \\
<.03 \\
<.03 \\
<.03 \\
<.03\end{array}$ & $\begin{array}{l}<9 \\
<9 \\
<9 \\
<9 \\
<9\end{array}$ & $\begin{array}{l}<.1 \\
<.1 \\
<.1 \\
<.1 \\
<.1\end{array}$ & $\begin{array}{l}<.2 \\
<.2 \\
<.2 \\
<.2 \\
<.2\end{array}$ & $\begin{array}{l}<.3 \\
<.3 \\
<.3 \\
<.3 \\
<.3\end{array}$ & $\begin{array}{l}<.3 \\
<.3 \\
<.3 \\
<.3 \\
<.3\end{array}$ & $\begin{array}{l}<.6 \\
<.6 \\
<.6 \\
<.6 \\
<.6\end{array}$ & $\begin{array}{l}<.04 \\
<.04 \\
<.04 \\
<.04 \\
<.04\end{array}$ & $\begin{array}{l}<1 \\
<1 \\
<1 \\
<1 \\
<1\end{array}$ & $\begin{array}{l}<.2 \\
<.2 \\
<.2 \\
<.2 \\
<.2\end{array}$ & $\begin{array}{l}<.2 \\
<.2 \\
<.2 \\
<.2 \\
<.2\end{array}$ \\
\hline $\begin{array}{l}372956099512201 \\
373229101193201 \\
373345101070801 \\
373507102162001 \\
373527100312701\end{array}$ & $\begin{array}{l}<.03 \\
<.03 \\
<.03 \\
<.03 \\
<.03\end{array}$ & $\begin{array}{l}<.03 \\
<.03 \\
<.03 \\
<.03 \\
<.03\end{array}$ & $\begin{array}{l}<9 \\
<9 \\
<9 \\
<9 \\
<9\end{array}$ & $\begin{array}{l}<.1 \\
<.1 \\
<.1 \\
<.1 \\
<.1\end{array}$ & $\begin{array}{l}<.2 \\
<.2 \\
<.2 \\
<.2 \\
<.2\end{array}$ & $\begin{array}{l}<.3 \\
<.3 \\
<.3 \\
<.3 \\
<.3\end{array}$ & $\begin{array}{l}<.3 \\
<.3 \\
<.3 \\
<.3 \\
<.3\end{array}$ & $\begin{array}{l}<.6 \\
<.6 \\
<.6 \\
<.6 \\
<.6\end{array}$ & $\begin{array}{l}<.04 \\
<.04 \\
<.04 \\
<.04 \\
<.04\end{array}$ & $\begin{array}{l}<1 \\
<1 \\
<1 \\
<1 \\
<1\end{array}$ & $\begin{array}{l}<.2 \\
<.2 \\
<.2 \\
<.2 \\
<.2\end{array}$ & $\begin{array}{l}<.2 \\
<.2 \\
<.2 \\
<.2 \\
<.2\end{array}$ \\
\hline $\begin{array}{l}373559102314901 \\
373732099291201 \\
374535102110301 \\
374650100181901 \\
375129100532301\end{array}$ & $\begin{array}{l}<.03 \\
<.03 \\
<.03 \\
<.03 \\
<.03\end{array}$ & $\begin{array}{l}<.03 \\
<.03 \\
<.03 \\
<.03 \\
<.03\end{array}$ & $\begin{array}{l}<9 \\
<9 \\
<9 \\
<9 \\
<9\end{array}$ & $\begin{array}{l}<.1 \\
<.1 \\
<.1 \\
<.1 \\
<.1\end{array}$ & $\begin{array}{l}<.2 \\
<.2 \\
<.2 \\
<.2 \\
<.2\end{array}$ & $\begin{array}{l}<.3 \\
<.3 \\
<.3 \\
<.3 \\
<.3\end{array}$ & $\begin{array}{l}<.3 \\
<.3 \\
<.3 \\
<.3 \\
<.3\end{array}$ & $\begin{array}{l}<.6 \\
<.6 \\
<.6 \\
<.6 \\
<.6\end{array}$ & $\begin{array}{l}<.04 \\
<.04 \\
<.04 \\
<.04 \\
<.04\end{array}$ & $\begin{array}{l}<1 \\
<1 \\
<1 \\
<1 \\
<1\end{array}$ & $\begin{array}{l}<.2 \\
<.2 \\
<.2 \\
<.2 \\
<.2\end{array}$ & $\begin{array}{l}<.2 \\
<.2 \\
<.2 \\
<.2 \\
<.2\end{array}$ \\
\hline $\begin{array}{l}375447099245001 \\
375828101111801 \\
380331100352801 \\
382947100443201 \\
383008101315601\end{array}$ & $\begin{array}{l}<.03 \\
<.03 \\
<.03 \\
<.03 \\
<.03\end{array}$ & $\begin{array}{l}<.03 \\
<.03 \\
<.03 \\
<.03 \\
<.03\end{array}$ & $\begin{array}{l}<9 \\
<9 \\
<9 \\
<9 \\
<9\end{array}$ & $\begin{array}{l}<.1 \\
<.1 \\
<.1 \\
<.1 \\
<.1\end{array}$ & $\begin{array}{l}<.2 \\
<.2 \\
<.2 \\
<.2 \\
<.2\end{array}$ & $\begin{array}{l}<.3 \\
<.3 \\
<.3 \\
<.3 \\
<.3\end{array}$ & $\begin{array}{l}<.3 \\
<.3 \\
<.3 \\
<.3 \\
<.3\end{array}$ & $\begin{array}{l}<.6 \\
<.6 \\
<.6 \\
<.6 \\
<.6\end{array}$ & $\begin{array}{l}<.04 \\
<.04 \\
<.04 \\
<.04 \\
<.04\end{array}$ & $\begin{array}{l}<1 \\
<1 \\
<1 \\
<1 \\
<1\end{array}$ & $\begin{array}{l}<.2 \\
<.2 \\
<.2 \\
<.2 \\
<.2\end{array}$ & $\begin{array}{l}<.2 \\
<.2 \\
<.2 \\
<.2 \\
<.2\end{array}$ \\
\hline $\begin{array}{l}383758101195801 \\
383919101040101 \\
385210100164501 \\
385904099522201 \\
390622101003201\end{array}$ & $\begin{array}{l}<.03 \\
<.03 \\
<.03 \\
<.03 \\
<.03\end{array}$ & $\begin{array}{l}<.03 \\
<.03 \\
<.03 \\
<.03 \\
<.03\end{array}$ & $\begin{array}{l}<9 \\
<9 \\
<9 \\
<9 \\
<9\end{array}$ & $\begin{array}{l}<.1 \\
<.1 \\
<.1 \\
<.1 \\
<.1\end{array}$ & $\begin{array}{l}<.2 \\
<.2 \\
<.2 \\
<.2 \\
<.2\end{array}$ & $\begin{array}{l}<.3 \\
<.3 \\
<.3 \\
<.3 \\
<.3\end{array}$ & $\begin{array}{l}<.3 \\
<.3 \\
<.3 \\
<.3 \\
<.3\end{array}$ & $\begin{array}{l}<.6 \\
<.6 \\
<.6 \\
<.6 \\
<.6\end{array}$ & $\begin{array}{l}<.04 \\
<.04 \\
<.04 \\
<.04 \\
<.04\end{array}$ & $\begin{array}{l}<1 \\
<1 \\
<1 \\
<1 \\
<1\end{array}$ & $\begin{array}{l}<.2 \\
<.2 \\
<.2 \\
<.2 \\
<.2\end{array}$ & $\begin{array}{l}<.2 \\
<.2 \\
<.2 \\
<.2 \\
<.2\end{array}$ \\
\hline $\begin{array}{l}390830102052001 \\
390838100411701 \\
391044100051001 \\
391921101385501\end{array}$ & $\begin{array}{l}<.03 \\
<.03 \\
<.03 \\
<.03\end{array}$ & $\begin{array}{l}<.03 \\
<.03 \\
<.03 \\
<.03\end{array}$ & $\begin{array}{l}<9 \\
<9 \\
<9 \\
<9\end{array}$ & $\begin{array}{l}<.1 \\
<.1 \\
<.1 \\
<.1\end{array}$ & $\begin{array}{l}<.2 \\
<.2 \\
<.2 \\
<.2\end{array}$ & $\begin{array}{l}<.3 \\
<.3 \\
<.3 \\
<.3\end{array}$ & $\begin{array}{l}<.3 \\
<.3 \\
<.3 \\
<.3\end{array}$ & $\begin{array}{l}<.6 \\
<.6 \\
<.6 \\
<.6\end{array}$ & $\begin{array}{l}<.04 \\
<.04 \\
<.04 \\
<.04\end{array}$ & $\begin{array}{l}<1 \\
<1 \\
<1 \\
<1\end{array}$ & $\begin{array}{l}<.2 \\
<.2 \\
<.2 \\
<.2\end{array}$ & $\begin{array}{l}<.2 \\
<.2 \\
<.2 \\
<.2\end{array}$ \\
\hline
\end{tabular}


STATION NUMBER

344800101324901 345826100580501 351656101161101 351914101204401 352035100293301

352249100425401 352513101372101 353110100550401 353941102350201

354248100501501 354331102183601 354348102543601 354656099480301

354918102020901 355701100313001 355852101274101
355916103215201 360703102361901

360838102560301 360944100162101 361014100221001 361049100564901 361054101393601

361114099420501 361517102065301 362115101173901 362134102035101 362615100435801

362744102334901 363057101384701 363104100035501 363154099310401 363157102565601

363239100301801 363427102440401 364219101394101 365223102113001

365422101083701 365445100381901 365821101375301 365934101573001 370358100510301

370458101514401 370724100281601 371738101220301 372534100443501 372649101344701

372956099512201 373229101193201 373345101070801 373507102162001 373527100312701

373559102314901 373732099291201 374535102110301 374650100181901 375129100532301

375447099245001 375828101111801 380331100352801 382947100443201 383008101315601

383758101195801 383919101040101 385210100164501 385904099522201 390622101003201

390830102052001 390838100411701 391044100051001 391921101385501

METHYL-
ETHYL-
KETONE
WATER
WHOLE
TOTAL
(UG/L)

$\begin{array}{ccc}\text { METHYL } & \text { META/ } & \\ \text { ISO- } & \text { PARA- } & \\ \text { BUTYL } & \text { XYLENE } & \\ \text { KETONE } & \text { WATER } & \text { NAPHTH- } \\ \text { WAT.WH. } & \text { UNFLTRD } & \text { ALENE } \\ \text { TOTAL } & \text { REC } & \text { TOTAL } \\ \text { (UG/L) } & \text { (UG/L) } & \text { (UG/L) }\end{array}$

O-
CHLORO-
TOLUENE
WATER
WHOLE
TOTAL
(UG/L)

O-
XYLENE
WATER
WHOLE
TOTAL
(UG/L)

P-ISO-

PROPYL- TETRA 1,3-DITOLUENE METHYL CHLOROWATER BENZENE PROPANE WHOLE UNFLTRD WAT. WH REC REC TOTAI $\begin{array}{llll}\text { TOTAL } & \text { TOTAL } & \text { TOTAL } & \text { TOTA } \\ (\mathrm{UG} / \mathrm{L}) & \text { (UG/L) } & \text { (UG/L) } & \text { (UG/ })\end{array}$

$\begin{array}{llll}<.1 & <.2 & <.4 & <2 \\ <.1 & <.2 & <.4 & <2 \\ <.1 & <.2 & <.4 & <2 \\ <.1 & <.2 & <.4 & <2 \\ <.1 & <.2 & <.4 & <2 \\ & & & \\ <.1 & <.2 & <.4 & <2 \\ <.1 & <.2 & <.4 & <2 \\ <.1 & <.2 & <.4 & <2 \\ <.1 & <.2 & <.4 & <2 \\ <.1 & <.2 & <.4 & <2 \\ & & & \\ <.1 & <.2 & <.4 & <2 \\ <.1 & <.2 & <.4 & <2 \\ <.1 & <.2 & <.4 & <2 \\ <.1 & <.2 & <.4 & <2 \\ <.1 & <.2 & <.4 & <2 \\ & & & \\ <.1 & <.2 & <.4 & <2 \\ <.1 & <.2 & <.4 & <2 \\ <.1 & <.2 & <.4 & <2 \\ <.1 & <.2 & <.4 & <2 \\ <.1 & <.2 & <.4 & <2\end{array}$

$<.4<.06$

$<.2$

$<.04$

$\begin{array}{llll}<.4 & <.06 & <.2 & <.04 \\ <.4 & <.06 & <.2 & <.04\end{array}$

$\begin{array}{llll}<.4 & <.06 & <.2 & <.04 \\ <.4 & <.06 & <.2 & <.04\end{array}$

$<.06$

$<.06$

$<.06$
$<.06$

$<.11$

$<.11$

$<.11$
$<.11$ (UG/L)

$<.2<.1$

$\begin{array}{llll}<.4 & <.06 & <.2 & <.04\end{array}$

$<.4<.06<.2<<.04$

$<.4<.4<6$

$\begin{array}{ll}<.4 & <.06 \\ <.4 & <.06\end{array}$

$<.2<.04$

$<.06$

$<.06$

$<.06$

$<.06$
$<.06$

$<.11$
$<.11$

$<.11$

$<.11$

$<.06$

$\begin{array}{ll}<.4 & <.06 \\ <.4 & <.06 \\ <.4 & <.06 \\ <.4 & <.06\end{array}$

$\begin{array}{ll}<.4 & <.06 \\ <.4 & <.06\end{array}$

$<.2<.04$

$\begin{array}{ll}<.2 & <.04 \\ <.2 & <.04\end{array}$

$<.2<.04$

$<.06$
$<.06$

$<.06$

$<.11$

$<.11$

$<.11$

$<.1$

$<.4<.06$

$<.4$
$<.4$

$<.4$
$<.4$

$<.2<.04$

$<.06<.2<.04$

$<.06<.2<.04$

$\begin{array}{lll}<.06 & <.2 & <.04 \\ <.06 & <.2 & <.04\end{array}$

$<.06$

$<.06$

$<.06$
$<.06$

$<.11$
$<.11$

$<.11$

$<.11$

\section{$<.4<.06$}

$<.1 \quad<.2$

$<.1$

$<.1$
$<.1$

$<.4$
$<.4$

$<.2$

$<.1<.2$

$<.1$

$<.1<<.2$

$<.1<.2$

$<.1<<.2$

$<.1<<.2$

$<.1$

$<.1$

$<.1$

$<.1$

$<.1<.2<.4$

$<.1$

$<.1$

$<.1$

$\begin{array}{lll}<.1 & <.2< \\ <.1 & <.2 & <.4\end{array}$

$<.1$

$<.1$
$<.1$

$\begin{array}{llll}<.1 & <.2 & <.4 & <2 \\ <.1 & <.2 & <.4 & <2 \\ <.1 & <.2 & <.4 & <2\end{array}$

$<.1<<.2<.4$

$<.1$

$<.2$

$<.4$

$<.2<.04$

$\begin{array}{llll}<.4 & <.06 & <.2 & <.04 \\ <.4 & <.06 & <.2 & <.04\end{array}$

$\begin{array}{ll}<.4 & <.06 \\ <.4 & <.06\end{array}$

$\begin{array}{ll}<.2 & <.04 \\ <.2 & <.04\end{array}$

$<.06$

$<.06$

$<.06$
$<.06$

$<.1$

$<.11$

$<.11$
$<.11$

$<.11$

$<.11$

$\begin{array}{ll}<.4 & <.06 \\ <.4 & <.06 \\ <.4 & <.06\end{array}$

$<.2<.04$

$<.2<.04$

$\begin{array}{ll}<.2 & <.04 \\ <.2 & <.04\end{array}$

$\begin{array}{ll}<.2 & <.04 \\ <.2 & <.04\end{array}$

$<.06$

$<.06$

$<.06$

$<.06$

$<.11$

$<.11$
$<.11$

$<.06$

$\begin{array}{llll}<.4 & <.06 & <.2 & <.04 \\ <.4 & <.06 & <.2 & <.04 \\ <.4 & <.06 & <.2 & <.04\end{array}$

$<.4<.06$

$<.4<.06$

$<.2<.04$

$<.06$

$<.06$

$<.11$

$<.11$

$<.11$

$<.11$

$<.06$

$<.06$

$\begin{array}{ll}<.4 & <.06 \\ <.4 & <.06 \\ <.4 & <.06\end{array}$

$<.2$
$<.2$
$<.2$

$<.04$
$<.04$

$<.04$
$<.04$

$<.2<.04$

$<.06$
$<.06$
$<.06$
$<.06$

$<.11$
$<.11$

$<.11$

$<.11$

$<.11$

$<.06$

$<.4 \quad<.06$

$\begin{array}{ll}<.4 & <.06 \\ <.4 & <.06\end{array}$

$<.2<.04$

$\begin{array}{ll}<.2 & <.04 \\ <.2 & <.04\end{array}$

$<.2<.04$

$<.4 \quad<.06$

$<.06$
$<.06$

$<.06$
$<.06$

$<.11$

$<.11$

$<.11$
$<.11$

$<.06$

$<.4<.06<.2<.04$

$\begin{array}{llll}<.4 & <.06 & <.2 & <.04 \\ <.4 & <.06 & <.2 & <.04\end{array}$

$\begin{array}{ll}<.4 & <.06 \\ <.4 & <.06\end{array}$

$<.11$

$<.11$

$<.11$

$<.06$

$<.11$

$<.4 \quad<.06$

$<.4<.06$

$\begin{array}{ll}<.4 & <.06 \\ <.4 & <.06\end{array}$

$<.2<.04$

$<.2<.04$

$<.2<.04$

$\begin{array}{ll}<.2 & <.04 \\ <.2 & <.04\end{array}$

$<.06$

$<.06$

$<.06$

$<.06$
$<.06$

$<.11$

$<.11$

$<.11$
$<.11$

$\begin{array}{ll}<.2 & <.04 \\ <.2 & <.04\end{array}$

$<.1$
$<.1$
$<.1$

$<.1$

$<.06$

$\begin{array}{ll}<.4 & <.06 \\ <.4 & <.06\end{array}$

$<.2<.04$

$<.2<.04$

$<.06$

$<.06$

$<.11$

$<.11$

$<.11$
$<.11$

$<.04$

$<.1$
$<.1$
$<.1$

$<.1$

$<.2$

$<.06$

$<.06$

$\begin{array}{ll}<.4 & <.06 \\ <.4 & <.06\end{array}$

$<.4<.06$

$<.11$

$\begin{array}{ll}<.2 & <.04 \\ <.2 & <.04\end{array}$

$<.2<.04$

$<.06$

$<.06$

$<.11$

$<.11$

$<.11$

$<.06$

$<.1$

$<.1$

$<.1$
$<.1$

$<.4<.06$

$\begin{array}{ll}<.4 & <.06 \\ <.4 & <.06\end{array}$

$\begin{array}{ll}<.4 & <.06 \\ <.4 & <.06\end{array}$

$<.2<.04$

$\begin{array}{ll}<.2 & <.04 \\ <.2 & <.04\end{array}$

$\begin{array}{ll}<.2 & <.04 \\ <.2 & <.04\end{array}$

$<.06$
$<.06$

$<.06$
$<.06$

$<.11$ 
Appendix 1. Water-quality data from 74 domestic water-supply wells completed in the central High Plains aquifer-Continued

\begin{tabular}{|c|c|c|c|c|c|c|c|c|c|c|c|c|}
\hline STATION NUMBER & $\begin{array}{c}\text { PROPENE } \\
3- \\
\text { CHLORO- } \\
\text { WATER } \\
\text { UNFLTRD } \\
\text { RECOVER } \\
\text { (UG/L) }\end{array}$ & $\begin{array}{l}\text { STYRENE } \\
\text { TOTAL } \\
\text { (UG/L) }\end{array}$ & $\begin{array}{l}\text { TETRA- } \\
\text { CHLORO- } \\
\text { ETHYL- } \\
\text { ENE } \\
\text { TOTAL } \\
\text { (UG/L) }\end{array}$ & $\begin{array}{l}\text { TOLUENE } \\
\text { O-ETHYL } \\
\text { WATER } \\
\text { UNFLTRD } \\
\text { RECOVER } \\
\text { (UG/L) }\end{array}$ & $\begin{array}{l}\text { TOLUENE } \\
\text { P-CHLOR } \\
\text { WATER } \\
\text { UNFLTRD } \\
\text { REC } \\
\text { (UG/L) }\end{array}$ & $\begin{array}{l}\text { TOLUENE } \\
\text { TOTAL } \\
\text { (UG/L) }\end{array}$ & $\begin{array}{c}\text { TRANS- } \\
1,3-D I- \\
\text { CHLORO- } \\
\text { PROPENE } \\
\text { TOTAL } \\
\text { (UG/L) }\end{array}$ & $\begin{array}{c}\text { TRI- } \\
\text { CHLORO- } \\
\text { ETHYL- } \\
\text { ENE } \\
\text { TOTAL } \\
\text { (UG/L) }\end{array}$ & $\begin{array}{l}\text { TRI- } \\
\text { CHLORO- } \\
\text { FLUORO- } \\
\text { METHANE } \\
\text { TOTAL } \\
\text { (UG/L) }\end{array}$ & $\begin{array}{l}\text { VINYL } \\
\text { CHLO- } \\
\text { RIDE } \\
\text { TOTAL } \\
\text { (UG/L) }\end{array}$ & $\begin{array}{l}\text { RADON } \\
222 \\
\text { TOTAL } \\
(\mathrm{PCI} / \mathrm{L})\end{array}$ & $\begin{array}{c}\text { TRITIUM } \\
\text { TOTAL } \\
\text { (PCI/L) }\end{array}$ \\
\hline $\begin{array}{l}344800101324901 \\
345826100580501 \\
351656101161101 \\
351914101204401 \\
352035100293301\end{array}$ & $\begin{array}{l}<.2 \\
<.2 \\
<.2 \\
<.2 \\
<.2\end{array}$ & $\begin{array}{l}<.04 \\
<.04 \\
<.04 \\
<.04 \\
<.04\end{array}$ & $\begin{array}{l}<.1 \\
<.1 \\
<.1 \\
<.1 \\
<.1\end{array}$ & $\begin{array}{l}<.10 \\
<.10 \\
<.10 \\
<.10 \\
<.10\end{array}$ & $\begin{array}{l}<.06 \\
<.06 \\
<.06 \\
<.06 \\
<.06\end{array}$ & $\begin{array}{l}<.05 \\
<.05 \\
<.05 \\
<.05 \\
<.05\end{array}$ & $\begin{array}{l}<.13 \\
<.13 \\
<.13 \\
<.13 \\
<.13\end{array}$ & $\begin{array}{l}<.04 \\
<.04 \\
<.04 \\
<.04 \\
<.04\end{array}$ & $\begin{array}{l}<.09 \\
<.09 \\
<.09 \\
<.09 \\
<.09\end{array}$ & $\begin{array}{l}<.1 \\
<.1 \\
<.1 \\
<.1 \\
<.1\end{array}$ & $\begin{array}{r}225 \\
486 \\
1440 \\
457 \\
249\end{array}$ & $\begin{array}{r}-- \\
-- \\
<1.0 \\
18.9 \\
2.6\end{array}$ \\
\hline $\begin{array}{l}352249100425401 \\
352513101372101 \\
352909101084001 \\
353110100550401 \\
353941102350201\end{array}$ & $\begin{array}{l}<.2 \\
<.2 \\
<.2 \\
<.2 \\
<.2\end{array}$ & $\begin{array}{l}<.04 \\
<.04 \\
<.04 \\
<.04 \\
<.04\end{array}$ & $\begin{array}{l}<.1 \\
<.1 \\
<.1 \\
<.1 \\
<.1\end{array}$ & $\begin{array}{l}<.10 \\
<.10 \\
<.10 \\
<.10 \\
<.10\end{array}$ & $\begin{array}{l}<.06 \\
<.06 \\
<.06 \\
<.06 \\
<.06\end{array}$ & $\begin{array}{l}<.05 \\
\mathrm{E} .05 \\
<.05 \\
<.05 \\
<.05\end{array}$ & $\begin{array}{l}<.13 \\
<.13 \\
<.13 \\
<.13 \\
<.13\end{array}$ & $\begin{array}{l}<.04 \\
<.04 \\
<.04 \\
<.04 \\
<.04\end{array}$ & $\begin{array}{l}<.09 \\
<.09 \\
<.09 \\
<.09 \\
<.09\end{array}$ & $\begin{array}{l}<.1 \\
<.1 \\
<.1 \\
<.1 \\
<.1\end{array}$ & $\begin{array}{l}274 \\
299 \\
260 \\
247 \\
683\end{array}$ & $\begin{array}{r}<1.0 \\
-- \\
<1.0 \\
<1.0 \\
<1.0\end{array}$ \\
\hline $\begin{array}{l}354248100501501 \\
354331102183601 \\
354348102543601 \\
354656099480301 \\
354728102295901\end{array}$ & $\begin{array}{l}<.2 \\
<.2 \\
<.2 \\
<.2 \\
<.2\end{array}$ & $\begin{array}{l}<.04 \\
<.04 \\
<.04 \\
<.04 \\
<.04\end{array}$ & $\begin{array}{l}<.1 \\
<.1 \\
<.1 \\
<.1 \\
<.1\end{array}$ & $\begin{array}{l}<.10 \\
<.10 \\
<.10 \\
<.10 \\
<.10\end{array}$ & $\begin{array}{l}<.06 \\
<.06 \\
<.06 \\
<.06 \\
<.06\end{array}$ & $\begin{array}{l}<.05 \\
<.05 \\
<.05 \\
\text { E.05 } \\
<.05\end{array}$ & $\begin{array}{l}<.13 \\
<.13 \\
<.13 \\
<.13 \\
<.13\end{array}$ & $\begin{array}{l}<.04 \\
<.04 \\
<.04 \\
<.04 \\
<.04\end{array}$ & $\begin{array}{l}<.09 \\
<.09 \\
<.09 \\
<.09 \\
<.09\end{array}$ & $\begin{array}{l}<.1 \\
<.1 \\
<.1 \\
<.1 \\
<.1\end{array}$ & $\begin{array}{l}236 \\
296 \\
468 \\
213 \\
642\end{array}$ & $\begin{array}{r}-- \\
<1.0 \\
<1.0 \\
--- \\
<1.0\end{array}$ \\
\hline $\begin{array}{l}354918102020901 \\
355701100313001 \\
355852101274101 \\
355916103215201 \\
360703102361901\end{array}$ & $\begin{array}{l}<.2 \\
<.2 \\
<.2 \\
<.2 \\
<.2\end{array}$ & $\begin{array}{l}<.04 \\
<.04 \\
<.04 \\
<.04 \\
<.04\end{array}$ & $\begin{array}{l}<.1 \\
<.1 \\
<.1 \\
<.1 \\
<.1\end{array}$ & $\begin{array}{l}<.10 \\
<.10 \\
<.10 \\
<.10 \\
<.10\end{array}$ & $\begin{array}{l}<.06 \\
<.06 \\
<.06 \\
<.06 \\
<.06\end{array}$ & $\begin{array}{l}<.05 \\
E .06 \\
<.05 \\
<.05 \\
<.05\end{array}$ & $\begin{array}{l}<.13 \\
<.13 \\
<.13 \\
<.13 \\
<.13\end{array}$ & $\begin{array}{l}<.04 \\
<.04 \\
<.04 \\
<.04 \\
<.04\end{array}$ & $\begin{array}{l}<.09 \\
<.09 \\
<.09 \\
<.09 \\
<.09\end{array}$ & $\begin{array}{l}<.1 \\
<.1 \\
<.1 \\
<.1 \\
<.1\end{array}$ & $\begin{array}{l}325 \\
332 \\
465 \\
704 \\
595\end{array}$ & $\begin{array}{r}<1.0 \\
33.3 \\
<1.0 \\
-- \\
<1.0\end{array}$ \\
\hline $\begin{array}{l}360838102560301 \\
360944100162101 \\
361014100221001 \\
361049100564901 \\
361054101393601\end{array}$ & $\begin{array}{l}<.2 \\
<.2 \\
<.2 \\
<.2 \\
<.2\end{array}$ & $\begin{array}{l}<.04 \\
<.04 \\
<.04 \\
<.04 \\
<.04\end{array}$ & $\begin{array}{l}<.1 \\
<.1 \\
<.1 \\
<.1 \\
<.1\end{array}$ & $\begin{array}{l}<.10 \\
<.10 \\
<.10 \\
<.10 \\
<.10\end{array}$ & $\begin{array}{l}<.06 \\
<.06 \\
<.06 \\
<.06 \\
<.06\end{array}$ & $\begin{array}{l}<.05 \\
<.05 \\
<.05 \\
\text { E.06 } \\
<.05\end{array}$ & $\begin{array}{l}<.13 \\
<.13 \\
<.13 \\
<.13 \\
<.13\end{array}$ & $\begin{array}{l}<.04 \\
<.04 \\
<.04 \\
<.04 \\
<.04\end{array}$ & $\begin{array}{l}<.09 \\
<.09 \\
<.09 \\
<.09 \\
<.09\end{array}$ & $\begin{array}{l}<.1 \\
<.1 \\
<.1 \\
<.1 \\
<.1\end{array}$ & $\begin{array}{r}516 \\
492 \\
379 \\
156 \\
1120\end{array}$ & $\begin{array}{r}13.4 \\
2.6 \\
1.0 \\
1.6 \\
<1.0\end{array}$ \\
\hline $\begin{array}{l}361114099420501 \\
361517102065301 \\
362115101173901 \\
362134102035101 \\
362615100435801\end{array}$ & $\begin{array}{l}<.2 \\
<.2 \\
<.2 \\
<.2 \\
<.2\end{array}$ & $\begin{array}{l}<.04 \\
<.04 \\
<.04 \\
<.04 \\
<.04\end{array}$ & $\begin{array}{l}<.1 \\
<.1 \\
<.1 \\
<.1 \\
<.1\end{array}$ & $\begin{array}{l}<.10 \\
<.10 \\
<.10 \\
<.10 \\
<.10\end{array}$ & $\begin{array}{l}<.06 \\
<.06 \\
<.06 \\
<.06 \\
<.06\end{array}$ & $\begin{array}{l}<.05 \\
<.05 \\
<.05 \\
<.05 \\
.14\end{array}$ & $\begin{array}{l}<.13 \\
<.13 \\
<.13 \\
<.13 \\
<.13\end{array}$ & $\begin{array}{l}<.04 \\
<.04 \\
<.04 \\
<.04 \\
<.04\end{array}$ & $\begin{array}{l}<.09 \\
<.09 \\
<.09 \\
<.09 \\
<.09\end{array}$ & $\begin{array}{l}<.1 \\
<.1 \\
<.1 \\
<.1 \\
<.1\end{array}$ & $\begin{array}{l}271 \\
827 \\
266 \\
623 \\
232\end{array}$ & $\begin{array}{r}--- \\
<1.0 \\
--- \\
<1.0 \\
<1.0\end{array}$ \\
\hline $\begin{array}{l}362744102334901 \\
363057101384701 \\
363104100035501 \\
363154099310401 \\
363157102565601\end{array}$ & $\begin{array}{l}<.2 \\
<.2 \\
<.2 \\
<.2 \\
<.2\end{array}$ & $\begin{array}{l}<.04 \\
<.04 \\
<.04 \\
<.04 \\
<.04\end{array}$ & $\begin{array}{l}\text { E. } 1 \\
<.1 \\
<.1 \\
<.1 \\
<.1\end{array}$ & $\begin{array}{l}<.10 \\
<.10 \\
<.10 \\
<.10 \\
<.10\end{array}$ & $\begin{array}{l}<.06 \\
<.06 \\
<.06 \\
<.06 \\
<.06\end{array}$ & $\begin{array}{l}<.05 \\
<.05 \\
<.05 \\
<.05 \\
<.05\end{array}$ & $\begin{array}{l}<.13 \\
<.13 \\
<.13 \\
<.13 \\
<.13\end{array}$ & $\begin{array}{l}<.04 \\
<.04 \\
<.04 \\
<.04 \\
<.04\end{array}$ & $\begin{array}{l}<.09 \\
<.09 \\
<.09 \\
<.09 \\
<.09\end{array}$ & $\begin{array}{l}<.1 \\
<.1 \\
<.1 \\
<.1 \\
<.1\end{array}$ & $\begin{array}{l}323 \\
499 \\
435 \\
228 \\
459\end{array}$ & $\begin{array}{r}1.0 \\
<1.0 \\
<1.0 \\
<1.0 \\
<1.0\end{array}$ \\
\hline $\begin{array}{l}363239100301801 \\
363427102440401 \\
364219101394101 \\
364411102321201 \\
365223102113001\end{array}$ & $\begin{array}{l}<.2 \\
<.2 \\
<.2 \\
<.2 \\
<.2\end{array}$ & $\begin{array}{l}<.04 \\
<.04 \\
<.04 \\
<.04 \\
<.04\end{array}$ & $\begin{array}{l}<.1 \\
<.1 \\
<.1 \\
<.1 \\
<.1\end{array}$ & $\begin{array}{l}<.10 \\
<.10 \\
<.10 \\
<.10 \\
<.10\end{array}$ & $\begin{array}{l}<.06 \\
<.06 \\
<.06 \\
<.06 \\
<.06\end{array}$ & $\begin{array}{l}\text { E. } 05 \\
<.05 \\
<.05 \\
<.05 \\
<.05\end{array}$ & $\begin{array}{l}<.13 \\
<.13 \\
<.13 \\
<.13 \\
<.13\end{array}$ & $\begin{array}{l}<.04 \\
<.04 \\
<.04 \\
<.04 \\
<.04\end{array}$ & $\begin{array}{l}<.09 \\
<.09 \\
<.09 \\
<.09 \\
<.09\end{array}$ & $\begin{array}{l}<.1 \\
<.1 \\
<.1 \\
<.1 \\
<.1\end{array}$ & $\begin{array}{r}401 \\
726 \\
364 \\
2040 \\
2030\end{array}$ & $\begin{array}{r}-- \\
-- \\
<1.0 \\
<1.0 \\
1.3\end{array}$ \\
\hline $\begin{array}{l}365422101083701 \\
365445100381901 \\
365821101375301 \\
365934101573001 \\
370358100510301\end{array}$ & $\begin{array}{l}<.2 \\
<.2 \\
<.2 \\
<.2 \\
<.2\end{array}$ & $\begin{array}{l}<.04 \\
<.04 \\
<.04 \\
<.04 \\
<.04\end{array}$ & $\begin{array}{l}<.1 \\
<.1 \\
<.1 \\
<.1 \\
<.1\end{array}$ & $\begin{array}{l}<.10 \\
<.10 \\
<.10 \\
<.10 \\
<.10\end{array}$ & $\begin{array}{l}<.06 \\
<.06 \\
<.06 \\
<.06 \\
<.06\end{array}$ & $\begin{array}{l}<.05 \\
\mathrm{E} .05 \\
<.05 \\
<.05 \\
<.05\end{array}$ & $\begin{array}{l}<.13 \\
<.13 \\
<.13 \\
<.13 \\
<.13\end{array}$ & $\begin{array}{l}<.04 \\
<.04 \\
<.04 \\
<.04 \\
<.04\end{array}$ & $\begin{array}{l}<.09 \\
<.09 \\
<.09 \\
<.09 \\
<.09\end{array}$ & $\begin{array}{l}<.1 \\
<.1 \\
<.1 \\
<.1 \\
<.1\end{array}$ & $\begin{array}{l}618 \\
344 \\
545 \\
477 \\
738\end{array}$ & $\begin{array}{r}-- \\
<1.0 \\
<1.0 \\
1.0 \\
<1.0\end{array}$ \\
\hline $\begin{array}{l}370458101514401 \\
370724100281601 \\
371738101220301 \\
372534100443501 \\
372649101344701\end{array}$ & $\begin{array}{l}<.2 \\
<.2 \\
<.2 \\
<.2 \\
<.2\end{array}$ & $\begin{array}{l}<.04 \\
<.04 \\
<.04 \\
<.04 \\
<.04\end{array}$ & $\begin{array}{l}<.1 \\
<.1 \\
<.1 \\
<.1 \\
<.1\end{array}$ & $\begin{array}{l}<.10 \\
<.10 \\
<.10 \\
<.10 \\
<.10\end{array}$ & $\begin{array}{l}<.06 \\
<.06 \\
<.06 \\
<.06 \\
<.06\end{array}$ & $\begin{array}{l}<.05 \\
<.05 \\
<.05 \\
<.05 \\
<.05\end{array}$ & $\begin{array}{l}<.13 \\
<.13 \\
<.13 \\
<.13 \\
<.13\end{array}$ & $\begin{array}{l}<.04 \\
<.04 \\
<.04 \\
<.04 \\
<.04\end{array}$ & $\begin{array}{l}<.09 \\
<.09 \\
<.09 \\
<.09 \\
<.09\end{array}$ & $\begin{array}{l}<.1 \\
<.1 \\
<.1 \\
<.1 \\
<.1\end{array}$ & $\begin{array}{l}322 \\
260 \\
282 \\
965 \\
453\end{array}$ & $\begin{array}{r}-- \\
<1.0 \\
<1.0 \\
-- \\
<1.0\end{array}$ \\
\hline $\begin{array}{l}372956099512201 \\
373229101193201 \\
373345101070801 \\
373507102162001 \\
373527100312701\end{array}$ & $\begin{array}{l}<.2 \\
<.2 \\
<.2 \\
<.2 \\
<.2\end{array}$ & $\begin{array}{l}<.04 \\
<.04 \\
<.04 \\
<.04 \\
<.04\end{array}$ & $\begin{array}{l}<.1 \\
<.1 \\
<.1 \\
<.1 \\
<.1\end{array}$ & $\begin{array}{l}<.10 \\
<.10 \\
<.10 \\
<.10 \\
<.10\end{array}$ & $\begin{array}{l}<.06 \\
<.06 \\
<.06 \\
<.06 \\
<.06\end{array}$ & $\begin{array}{l}<.05 \\
<.05 \\
<.05 \\
<.05 \\
<.05\end{array}$ & $\begin{array}{l}<.13 \\
<.13 \\
<.13 \\
<.13 \\
<.13\end{array}$ & $\begin{array}{l}<.04 \\
<.04 \\
<.04 \\
<.04 \\
<.04\end{array}$ & $\begin{array}{l}<.09 \\
<.09 \\
<.09 \\
<.09 \\
<.09\end{array}$ & $\begin{array}{l}<.1 \\
<.1 \\
<.1 \\
<.1 \\
<.1\end{array}$ & $\begin{array}{r}257 \\
787 \\
1010 \\
2950 \\
1110\end{array}$ & $\begin{array}{r}<1.0 \\
<1.0 \\
-- \\
1.9 \\
<1.0\end{array}$ \\
\hline $\begin{array}{l}373559102314901 \\
373732099291201 \\
374535102110301 \\
374650100181901 \\
375129100532301\end{array}$ & $\begin{array}{l}<.2 \\
<.2 \\
<.2 \\
<.2 \\
<.2\end{array}$ & $\begin{array}{l}<.04 \\
<.04 \\
<.04 \\
<.04 \\
<.04\end{array}$ & $\begin{array}{l}<.1 \\
<.1 \\
<.1 \\
<.1 \\
<.1\end{array}$ & $\begin{array}{l}<.10 \\
<.10 \\
<.10 \\
<.10 \\
<.10\end{array}$ & $\begin{array}{l}<.06 \\
<.06 \\
<.06 \\
<.06 \\
<.06\end{array}$ & $\begin{array}{l}<.05 \\
<.05 \\
<.05 \\
<.05 \\
<.05\end{array}$ & $\begin{array}{l}<.13 \\
<.13 \\
<.13 \\
<.13 \\
<.13\end{array}$ & $\begin{array}{l}<.04 \\
<.04 \\
<.04 \\
<.04 \\
<.04\end{array}$ & $\begin{array}{l}<.09 \\
<.09 \\
<.09 \\
<.09 \\
<.09\end{array}$ & $\begin{array}{l}<.1 \\
<.1 \\
<.1 \\
<.1 \\
<.1\end{array}$ & $\begin{array}{r}1400 \\
378 \\
420 \\
775 \\
383\end{array}$ & $\begin{array}{r}1.3 \\
-- \\
8.3 \\
-- \\
<1.0\end{array}$ \\
\hline $\begin{array}{l}375447099245001 \\
375828101111801 \\
380331100352801 \\
382947100443201 \\
383008101315601\end{array}$ & $\begin{array}{l}<.2 \\
<.2 \\
<.2 \\
<.2 \\
<.2\end{array}$ & $\begin{array}{l}<.04 \\
<.04 \\
<.04 \\
<.04 \\
<.04\end{array}$ & $\begin{array}{l}<.1 \\
<.1 \\
<.1 \\
<.1 \\
<.1\end{array}$ & $\begin{array}{l}<.10 \\
<.10 \\
<.10 \\
<.10 \\
<.10\end{array}$ & $\begin{array}{l}<.06 \\
<.06 \\
<.06 \\
<.06 \\
<.06\end{array}$ & $\begin{array}{l}<.05 \\
<.05 \\
<.05 \\
.16 \\
<.05\end{array}$ & $\begin{array}{l}<.13 \\
<.13 \\
<.13 \\
<.13 \\
<.13\end{array}$ & $\begin{array}{l}<.04 \\
<.04 \\
<.04 \\
<.04 \\
<.04\end{array}$ & $\begin{array}{l}<.09 \\
<.09 \\
<.09 \\
<.09 \\
<.09\end{array}$ & $\begin{array}{l}<.1 \\
<.1 \\
<.1 \\
<.1 \\
<.1\end{array}$ & $\begin{array}{r}1580 \\
514 \\
992 \\
937 \\
986\end{array}$ & $\begin{array}{r}-- \\
18.2 \\
10.2 \\
1.0 \\
--\end{array}$ \\
\hline $\begin{array}{l}383758101195801 \\
383919101040101 \\
385210100164501 \\
385904099522201 \\
390622101003201\end{array}$ & $\begin{array}{l}<.2 \\
<.2 \\
<.2 \\
<.2 \\
<.2\end{array}$ & $\begin{array}{l}<.04 \\
<.04 \\
<.04 \\
<.04 \\
<.04\end{array}$ & $\begin{array}{l}<.1 \\
<.1 \\
<.1 \\
<.1 \\
<.1\end{array}$ & $\begin{array}{l}<.10 \\
<.10 \\
<.10 \\
<.10 \\
<.10\end{array}$ & $\begin{array}{l}<.06 \\
<.06 \\
<.06 \\
<.06 \\
<.06\end{array}$ & $\begin{array}{l}<.05 \\
<.05 \\
<.05 \\
<.05 \\
<.05\end{array}$ & $\begin{array}{l}<.13 \\
<.13 \\
<.13 \\
<.13 \\
<.13\end{array}$ & $\begin{array}{l}<.04 \\
<.04 \\
<.04 \\
<.04 \\
<.04\end{array}$ & $\begin{array}{l}<.09 \\
<.09 \\
<.09 \\
<.09 \\
<.09\end{array}$ & $\begin{array}{l}<.1 \\
<.1 \\
<.1 \\
<.1 \\
<.1\end{array}$ & $\begin{array}{l}768 \\
722 \\
370 \\
227 \\
458\end{array}$ & $\begin{array}{r}-- \\
-- \\
<1.0 \\
-- \\
--\end{array}$ \\
\hline $\begin{array}{l}390830102052001 \\
390838100411701 \\
391044100051001 \\
391921101385501\end{array}$ & $\begin{array}{l}<.2 \\
<.2 \\
<.2 \\
<.2\end{array}$ & $\begin{array}{l}<.04 \\
<.04 \\
<.04 \\
<.04\end{array}$ & $\begin{array}{l}<.1 \\
<.1 \\
<.1 \\
<.1\end{array}$ & $\begin{array}{l}<.10 \\
<.10 \\
<.10 \\
<.10\end{array}$ & $\begin{array}{l}<.06 \\
<.06 \\
<.06 \\
<.06\end{array}$ & $\begin{array}{l}<.05 \\
<.05 \\
<.05 \\
<.05\end{array}$ & $\begin{array}{l}<.13 \\
<.13 \\
<.13 \\
<.13\end{array}$ & $\begin{array}{l}<.04 \\
<.04 \\
<.04 \\
<.04\end{array}$ & $\begin{array}{l}<.09 \\
<.09 \\
<.09 \\
<.09\end{array}$ & $\begin{array}{l}<.1 \\
<.1 \\
<.1 \\
<.1\end{array}$ & $\begin{array}{l}237 \\
812 \\
461 \\
688\end{array}$ & $\begin{array}{r}1.0 \\
10.6 \\
-- \\
--\end{array}$ \\
\hline
\end{tabular}


Appendix 1. Water-quality data from 74 domestic water-supply wells completed in the central High Plains aquifer-Continued

\begin{tabular}{|c|c|c|}
\hline STATION & $\begin{array}{c}\text { TRITIUM } \\
2 \text { SIGMA } \\
\text { WATER, } \\
\text { WHOLE, } \\
\text { TOTAL } \\
\text { (PCI/L) }\end{array}$ & $\begin{array}{c}\text { URANIUM } \\
\text { NATURAL } \\
\text { DIS- } \\
\text { SOLVED } \\
\text { (UG/L } \\
\text { AS U) }\end{array}$ \\
\hline $\begin{array}{l}344800101324901 \\
345826100580501 \\
351656101161101 \\
351914101204401 \\
352035100293301\end{array}$ & $\begin{array}{r}-- \\
-- \\
1.0 \\
1.6 \\
1.0\end{array}$ & $\begin{array}{l}5.48 \\
1.36 \\
5.33 \\
7.95 \\
1.15\end{array}$ \\
\hline $\begin{array}{l}352249100425401 \\
352513101372101 \\
352909101084001 \\
353110100550401 \\
353941102350201\end{array}$ & $\begin{array}{l}1.0 \\
-- \\
1.0 \\
1.0 \\
1.0\end{array}$ & $\begin{array}{r}<1.00 \\
4.07 \\
4.65 \\
6.80 \\
7.77\end{array}$ \\
\hline $\begin{array}{l}354248100501501 \\
354331102183601 \\
354348102543601 \\
354656099480301 \\
354728102295901\end{array}$ & $\begin{array}{r}-- \\
1.0 \\
1.0 \\
-- \\
1.0\end{array}$ & $\begin{array}{l}4.46 \\
6.71 \\
2.95 \\
2.18 \\
7.11\end{array}$ \\
\hline $\begin{array}{l}354918102020901 \\
355701100313001 \\
355852101274101 \\
355916103215201 \\
360703102361901\end{array}$ & $\begin{array}{r}1.0 \\
2.6 \\
1.0 \\
-- \\
1.0\end{array}$ & $\begin{array}{l}7.24 \\
4.95 \\
6.89 \\
6.59 \\
5.78\end{array}$ \\
\hline $\begin{array}{l}360838102560301 \\
360944100162101 \\
361014100221001 \\
361049100564901 \\
361054101393601\end{array}$ & $\begin{array}{l}1.3 \\
1.0 \\
1.0 \\
1.0 \\
1.0\end{array}$ & $\begin{array}{l}4.54 \\
8.83 \\
6.52 \\
9.98 \\
11.6\end{array}$ \\
\hline $\begin{array}{l}361114099420501 \\
361517102065301 \\
362115101173901 \\
362134102035101 \\
362615100435801\end{array}$ & $\begin{array}{r}-- \\
1.0 \\
-- \\
1.0 \\
1.0\end{array}$ & $\begin{array}{c}1.55 \\
8.56 \\
7.84 \\
11.5 \\
7.88\end{array}$ \\
\hline $\begin{array}{l}362744102334901 \\
363057101384701 \\
363104100035501 \\
363154099310401 \\
363157102565601\end{array}$ & $\begin{array}{l}1.0 \\
1.0 \\
1.0 \\
1.0 \\
1.0\end{array}$ & $\begin{array}{r}13.4 \\
8.56 \\
9.04 \\
1.63 \\
3.76\end{array}$ \\
\hline $\begin{array}{l}363239100301801 \\
363427102440401 \\
364219101394101 \\
364411102321201 \\
365223102113001\end{array}$ & $\begin{array}{l}-- \\
-- \\
1.0 \\
1.0 \\
1.0\end{array}$ & $\begin{array}{c}8.55 \\
6.12 \\
14.9 \\
6.90 \\
9.88\end{array}$ \\
\hline $\begin{array}{l}365422101083701 \\
365445100381901 \\
365821101375301 \\
365934101573001 \\
370358100510301\end{array}$ & $\begin{array}{l}-- \\
1.0 \\
1.0 \\
1.0 \\
1.0\end{array}$ & $\begin{array}{l}8.05 \\
11.5 \\
13.9 \\
21.2 \\
7.40\end{array}$ \\
\hline $\begin{array}{l}370458101514401 \\
370724100281601 \\
371738101220301 \\
372534100443501 \\
372649101344701\end{array}$ & $\begin{array}{r}-- \\
1.0 \\
1.0 \\
-- \\
1.0\end{array}$ & $\begin{array}{r}2.65 \\
4.88 \\
6.75 \\
13.5 \\
8.30\end{array}$ \\
\hline $\begin{array}{l}372956099512201 \\
373229101193201 \\
373345101070801 \\
373507102162001 \\
373527100312701\end{array}$ & $\begin{array}{r}1.0 \\
1.0 \\
-- \\
1.0 \\
1.0\end{array}$ & $\begin{array}{c}6.03 \\
15.7 \\
8.73 \\
6.28 \\
11.9\end{array}$ \\
\hline $\begin{array}{l}373559102314901 \\
373732099291201 \\
374535102110301 \\
374650100181901 \\
375129100532301\end{array}$ & $\begin{array}{r}1.0 \\
-- \\
1.0 \\
-- \\
1.0\end{array}$ & $\begin{array}{l}9.81 \\
2.48 \\
5.17 \\
4.43 \\
3.48\end{array}$ \\
\hline $\begin{array}{l}375447099245001 \\
375828101111801 \\
380331100352801 \\
382947100443201 \\
383008101315601\end{array}$ & $\begin{array}{r}-- \\
1.3 \\
1.3 \\
1.0 \\
--\end{array}$ & $\begin{array}{l}11.8 \\
30.7 \\
18.9 \\
19.8 \\
10.1\end{array}$ \\
\hline $\begin{array}{l}383758101195801 \\
383919101040101 \\
385210100164501 \\
385904099522201 \\
390622101003201\end{array}$ & $\begin{array}{r}-- \\
-- \\
1.0 \\
-- \\
--\end{array}$ & $\begin{array}{r}17.5 \\
12.1 \\
2.51 \\
3.98 \\
13.0\end{array}$ \\
\hline $\begin{array}{l}390830102052001 \\
390838100411701 \\
391044100051001 \\
391921101385501\end{array}$ & $\begin{array}{r}1.0 \\
1.0 \\
-- \\
--\end{array}$ & $\begin{array}{l}6.09 \\
10.5 \\
3.91 \\
13.4\end{array}$ \\
\hline
\end{tabular}


